634.9

F 74

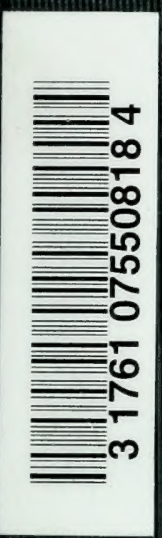




$$
\frac{634,9}{F 74}
$$






\section{THE DEVELOPMENT OF BRITISH FORESTRY}



$25^{55^{6}}$

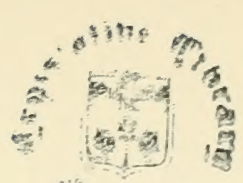

\section{THE DEVELOPMENT OF}

\section{B R I TISH H FORESTRY Y $\left.e_{0}^{\infty}\right)^{2}$ is (s) (2) \\ BY}

A. C. FORBES, F.H.A.S.

CHIEF FORESTRY INSPECTOR TO THE DEPARTMENT OF AGRICULTURE

FOR IRELAND

AUTHOR OF 'ENGLISH ESTATE FORESTRY,' ETC.

ILLUSTRATED

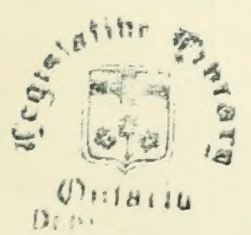

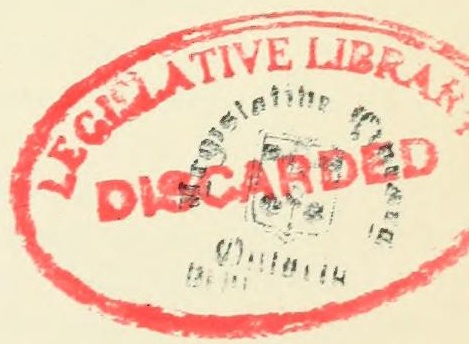

LONDON

EDWARD ARNOLD

publisber to the fnota office

1910 


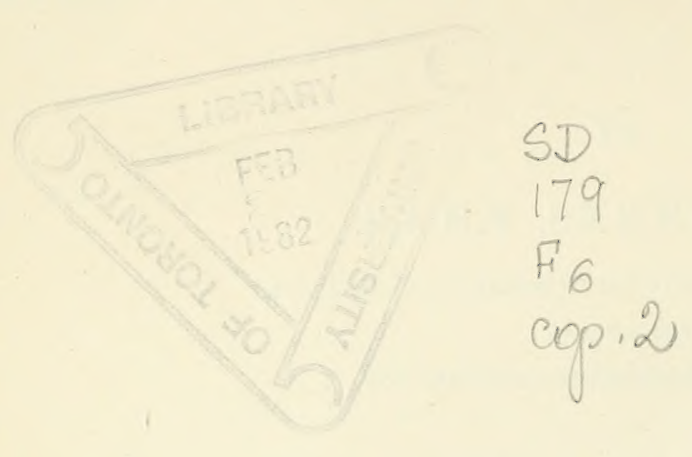




\section{PREFACE}

THE title of this volume was not chosen with any reference to a recently appointed Commission, but because the author believed that British Forestry, after lying almost dormant for about 500 years, was really developing at last. It is, as a matter of fact, a question of development or disappearance. The State is beginning to recognise the absolute necessity for action being taken on afforestation, and the private owner is at last realising that the continued existence of timber-yielding woodland is impossible without the skill and attention of the forester.

The questions for each party to decide at the present moinent are: Upon what lines shall development proceed? Are the experiences and sacrifices of the past to be ignored? Is the still small voice of the practical man to be unheeded in the din of discussions on impossible schemes? And are further sums of money and valuable time to be spent on useless inquiries or wasteful experiments?

An attempt has been made to present a general review of the whole problem of afforestation as it must appear to the landowner and the practical forester. Both the specialist and enthusiast are apt to forget that the productive land of Great Britain wass practically absorbed by or allotted to its various owners a century or two ago, and anything left over is of much the same value as the leavings and scrap-heaps of other industries. The Roman proverb, 'Ex nitilo nihil fit,' applies to timber-growing as much as to anything else, although, judging from state- 
ments frequently made, the only essential feature of timbergrowing land would appear to be its worthlessness for any other purpose.

Afforestation means, if it means anything, not so much the addition of a fresh asset to the existing wealth of the nation, as the readjustment of the balance between forestry and agriculture which was practically destroyed in or soon after the Middle Ages. That such a readjustment is desirable, if not absolutely necessary, is the confirmed opinion of all who have taken the trouble to look into facts. The only doubtful features are the methods which should be employed, and these are discussed in the following pages. Chapter vi. may be regarded as a slight digression from the main subject, the value of which the reader must judge for himself.

A. C. F. 


\section{CONTENTS}

CHAP.

I. SONE NATIONAL ASPECTS OF FORESTRY $\quad$. 1

II. THE FOREST REQUIREMENTS OF THE UNITED KINGDOM . . . . . . . . $\quad 29$

II. THE RELATION OF AGRICULTURE TO FORESTRY DEVELOPMENT . $\quad . \quad$. $\quad . \quad$. 59

IV. CLIMATE AND TREE GROWTH . . . . 87

V. SOIL AND SURFACE CONDITIONS IN THE BRI'TISH ISLES . . . . . . . . 122

VI. THE NEED FOR IMPROVED METHODS AND PRACTICE IN BRITISH FORESTRY . . . . . 148

VII. THE ECONOHIC VALUE OF THE BRITISH FOREST FLORA . . . . . . . 191

VIII. SOME FINANCIAL ASPECTS OF BRITISH FORESTRY 214

IX. THE STATE AND PRIVATE OWNERSHIP OF WOODS $236^{\circ}$

INDEX, . . . . . . . . 271 


\section{LIST OF TABLES}

Division of land in Great Britain (Agricultural Statistics for 1900), . . . . . . . . .

PAGE

Agricultural Statistics of Great Britain, showing changes in productions between 1877 and 1906, . . . . . 68

Some Agricultural Statistics of the British Isles-1906, 86

July and January Means for various Stations in North-Western Europe, . . . . . . . . . 92

Climatic Groups in Great Britain, . . . . . . . 92

July Means at High-Level Stations, . . . . . . . 94

Average Rainfall during May, June, July, and Angust at various

Stations in the British Isles, . . . . . . . $\quad 96$

Maximum Height (4rowths of Common Forest Trees in British

Isles, . . . . . . . . . . 98

Extremes of Cold borne by various Exotic Trees without Injury

in the Winter of 1892-1893, . . . . . . 120

Exotic and other Trees Killed and Injured in Scotland in Winter 1879-1880, . . . . . . . .

Number of Stems at different Ages usually found in German

Woods, . . . . . . . . 150

Diagram for Tree-Planting, . . . . . . . 162, 163

Some British and Irish Yields per acre, . . . . . . 231

Extracts from Continental Yield Tables, . . . . . 232

Capital C'ost of establishing Forest Blocks on a Working Lasis, . 233

Profit and Loss Account on Specimen Blocks after allowing 3 per cent. Interest on Capital Cost Values, . . . . 234

Yield of Timber and Firewood, and Nett Yield in Money per acre per annum, also Average Price per cubic foot, as obtained in State Forests in Germany in 1905, . . . . .

Ownership of Forest Areas in Percentages of Total Areas in European States, . $\quad$. . . . . . .

Distribution of a possible Forest A rea of $7,000,000$ acres throughout the British Isles, . . . . . . . . 268 


\section{LIST OF ILLUSTRATIONS}

1. Natural Ash and Oak Wood in south of Ireland, Facing page 2

2. Natural Oak and Holly-Ireland, . . . " , 2

3. Natural Oak after repeated coppicing, . . . , , 6

4. Old Oak Forest in mountain valley, . . . . . 6

5. Natural scrub of Ash, Holly, etc., . . . , , 15

6. Beech pollards, . . . . . . 15

7. Wind-swept Elm near sea, . . . . . . . 87

8. Beech-tops killed back by sea wind, . . " " 87

9. Windward edge of wood on West Coast of

Ireland, . . . . . . . ", 90

10. Beech and Silver Fir on windward edge of wood, . . . . . . . $\quad$. 90

11. Tops of Douglas Firs damaged by wind in West Highlands-15 to 20 miles from coast, . " 90

12. Edge of Silver Fir Wood near sea, . . . . " " 98

13. Ash on good ground-10 miles from West Coast, , " 98

14. Physical Map of North-Western Europe, . . , 102

15. Beech and Oak on western slope-Ireland800 feet. . . . . . . 102

16. Cembran Pine in Bavarian Alps—6000 feet, . " 107

17. Group of White American Spruce on Pennines -2000 feet, . . . . . , 107

18. Group of Norway Spruce on Pennines-1700 feet, . . . . . . 111

19. Spruce raised from seed-Bavarian Alps3500 feet, . . . . . . , 111

20. Larch on exposed ground-900 feet, . . " 114

21. Effect of cyclonic storm on young coniferous wood, . . . . . , 
22. White American Spruce at 1500 feet-Pennines, Facing page 119

23. Grazed Spruce Forest-Bavarian Alps-5000 feet,

24. Maritime Pine amongst natural scrub-West Coast of Ireland,

25. Mountain land denuded of surface soil,

26. Section of Millstone Grit, surface carrying good Scots Pine,

27. Gravel subsoil producing good timber,

28. Boulder-strewn surface carrying natural scrub,

29. Larch and Spruce on boulder-strewn slope,

30. Beech Clump on site of chalk-pit-Wiltshire Downs,

31. View inside Clump shown in Fig. 30,

32. Pocket of good soil on rock surface,

33. Larch on boulder-strewn surface, .

34. Ash, Sycamore, and Scots Pine on weathered limestone,

35. Surface covered with 'detritus' in Donegal,

36. Peat bog in hollow on mountain land, 1.36 136

37. 'Elfin' growth of Scots Pine on shallow soil800 feet, .

38. Mountain Pine covering 'talus' below snow line-7000 feet-Bavarian Alps,

39. Surface covered with grass and herbaceous plants-6000 feet-Bavarian Alps, . .

40. Peat-covered slopes on Pennines-2000-3000 feet,

41. Natural channels in mountain peat resting on boulder clay-2000 feet,

42. Surface denudation on hillside-West Highlands, . . . . . .

43. Scots Pine on 'high' bog-Treland. Trees in background shown in Fig. 44, . . .

44. Scots Pine on 'cut-away' bog,

45. Roots of Scots Pine in mountain peat-Donegal,

46. Natural Birch on bog, 
47. Natural and distorted root systems of Scots Pine, Facing page 159

48. Corsican Pine-transplanted-two-year, .

49. Two-year Maritime Pines grown in leaf mould -untransplanted, . . . . . . . .

50. Maritime Pines-two-year seedlings-untransplanted, . . . . . . . . . 159

51. Lifting Spruce with plough at Abbeyleix, . " " 165

52. Selection felling in Chiltern Hills' Beech Wood, " 172

53. Two-storeyed Beech Wood-Chiltern Hills, . ” 172

54. Pure Larch Wood-Northumberland, . . " " 194

55. Pure Larch Wood-West Highlands, . . „ " 194

56. Douglas Fir at Taymount, . . . . " " 194

57. Bavarian Spruce Forest, . . . . „ 194

58. Scots Pine thirty years old-Northumberland, „, 199

59. Pure Larch Wood twenty years old, . . " 202

60. Corsican Pine Clump-800 feet-Northumberland, . . . . . . , 202

61. Silver Fir Wood on mountain limestone-Sligo, , " 202

62. Beech High Forest, . . . . . " 202

63. Spruce Clump-County Cork, . . . " " 207

64. Oak from coppice shoots-Ireland, . . „ " 207

65. Pinus insignis at Muckross-thirty-five years of age, . . . . . . . 210

66. Cupressus macrocarpa as a timber tree, . . " " 210

67. Thuia gigantea (plicata) at Gairletter, Argyllshire, . . . . . . . 199

68. Avenue of Cornish Elms-Cornwall, . . . " 245

69. Artificial and natural clumps on chalk downs, . ", 252

70. Hedgerow English Elms in chalk country, . , 252

71. Mountain farm in West Highlands, . . " " 252 



\section{THE DEVELOPMENT OF BRITISH FORESTRY}

\section{CHAPTER I \\ SOME NATIONAL ASPECTS OF FORESTRY}

So far as we can learn from history and reason by analogy, the entire land surface of the globe, with certain exceptions, was originally covered with forest growth. These exceptions were, without going too closely into details, the arctic and antarctic circles, land lying above certain elevations on mountains and tablelands, and territories parched and dried up by heat and drought during the greater part of the year. Within the frigid zones, and at high elevations, insufficient warmth; within the torrid zones, insufficient moisture, are the two main factors respectively in accounting for the absence of forests, and in one guise or another these factors will be found responsible for the more limited failure of timber trees elsewhere. But while it appears to be a general law of nature that forests shall be the ultimate stage in the various evolutions of vegetative types, it is by no means certain that they have existed in their ordinary form as timber forest under every combination of climate, surface, and situation which may be found throughout the globe. In tracts of country with cold and dry winters, or hot and dry summers, many areas may be found which either do not appear to have carried more than a scanty forest growth at any time, or which only exhibit a stunted form of it usually known as 
'scrub or brush' forest. In this particular form, species, which under favourable conditions grow into tall and bulky timber trees, assume a shrubby or stunted habit, and while performing a definite and useful function in the economy of nature, fitil to aequire that size and valıe which are usually regarded as their natural characters. Poor or swampy soils, rocky surfaces, land exposed to strong sea winds, cold air currents, and climates with low summer temperatures or rainfalls, usually possess a large proportion of their forest areas in the form of scrub, and from a purely economic point of view, such forest must be distinguished from the more normal type, which produces timber and other products of considerable commercial value.

The above facts force one to the conclusion that the total forest area, whether of the world in general, or of a country or nation in particular, is of less importance as a national asset than the surface covered with productive forest, and taking a more or less important part in the political economy of a nation or civilisation generally. This productive timber forest may possess a commercial value, or it may not. In thinly populated countries, a large area of timber forest may yield an excessive supply of wood, which reduces its market value to the mere cost of exploitation or marketing. Under such conditions, which prevailed within the last hundred years or so in North America, Russia, Sweden, etc., a large forest area can only be considered an advantage when its timber can be marketed outside the country, and there exchanged for commodities of greater use and value to the community. The possibility of obtaining a profitable outside market depends very largely upon a comparative scarcity elsewhere, and facilities for cheap transit to a consuming centre. Timber being produced so abundantly under perfectly natural conditions throughout the greater part of the 


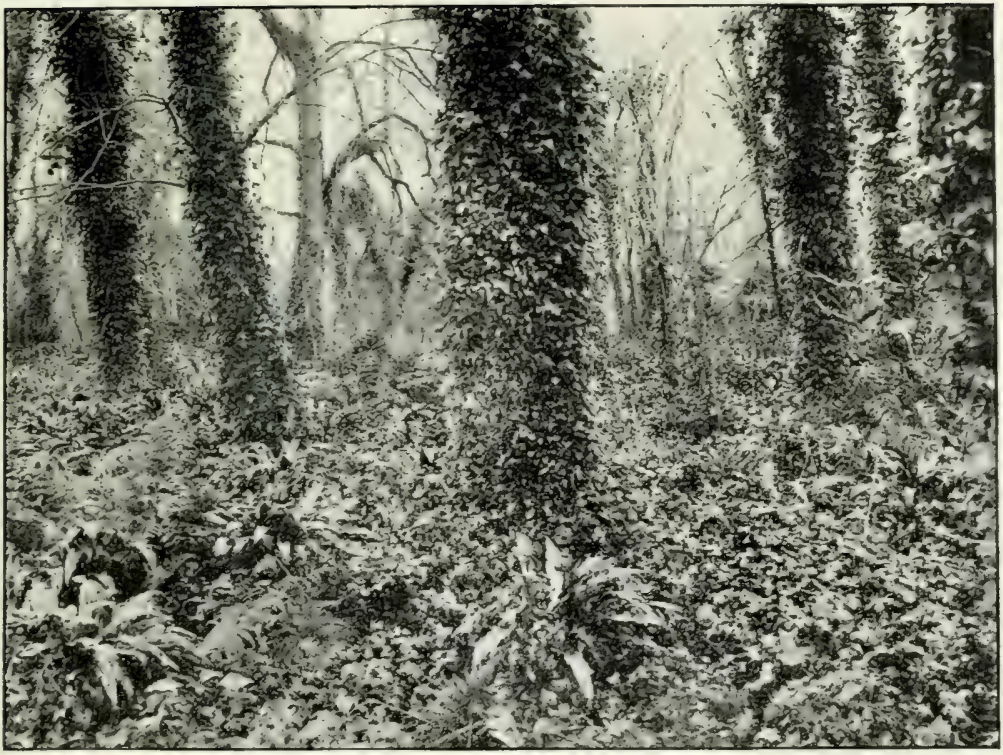

I. NATURAL ASH aND OAK WOOD IN SOUTH OF IREIAND.

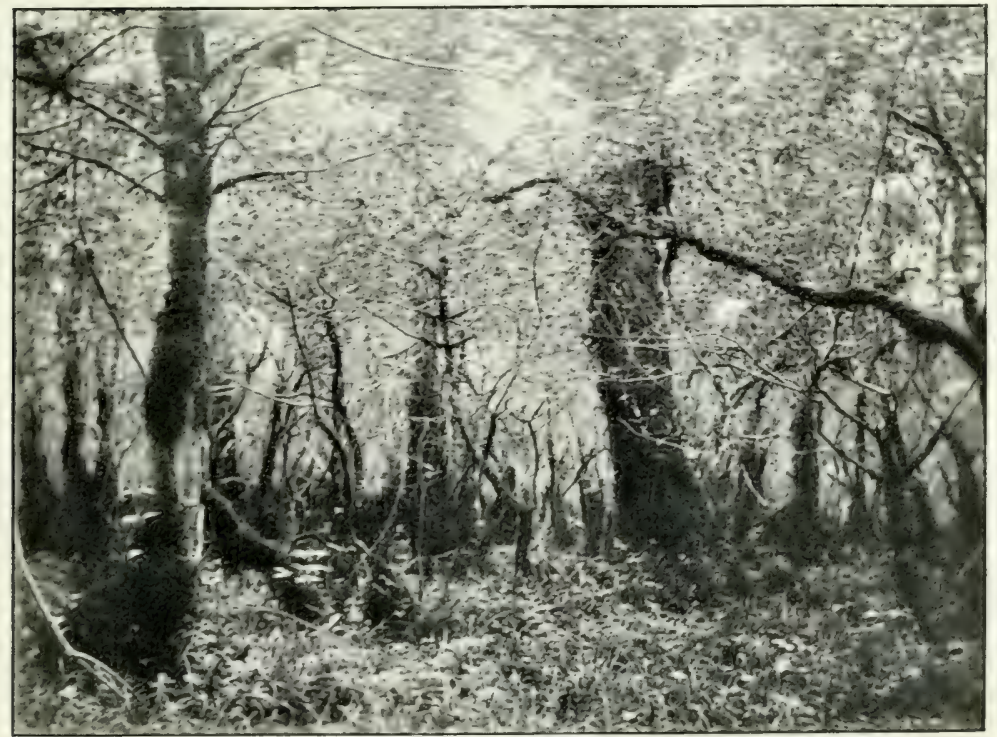

2. NATURAI, OAK ANI) IOLIY. [RFIANI). 

world, it is evident that a deficiency in any country must be attributed either to a dense population, or to the balance of nature, which provides for the more or less regular reproduction of animal and vegetable life, having been disturbed. In the former case, it is conceivable that a country possessing large and expanding industries may demand more timber than the natural forests of the country can produce. Great Britain, at the present time, is undoubtedly a case in point; for, assuming that the old natural forests of the country were restored, it would be impossible for them to meet the existing consumption of timber which is now going on, and leave a sufficient area outside their boundaries to furnish food for the people. But a far more frequent cause of a country experiencing a deficiency of timber may be found in a disturbance of the true balance of nature. This, apart from exceptional cases, invariably follows the advent of civilisation, or civilised men. When primitive races alone occupy a forest country, and live chiefly by hunting wild animals and fishing, the normal growth of the forest is sufficient to make good any loss occasioned by felling, grazing, or browsing of herbivorous animals, etc., and the general perpetuation of the woodland area is more or less spontaneous. An advance in civilisation, however, brings in its train many changes which adversely affect the natural forest. In the first place, the rudiments of sanitation and medical science on the one hand, and humanitarian principles on the other, lead to an increase in population, which was impossible in the days of intertribal warfare, uncertain means of subsistence, and the various fatalities incidental to a savage life. But the most potent factor of any as regards forest destruction is the gradual transition of a tribe from a hunting to a pastoral life, owing to the donestication of cattle, sheep, and goats, as wild game decreases, and the savage hand 
and eye lose their cunning in the chase. So long as the population keeps within narrow limits, is settled rather than nomadic in its habits, and cattle or swine predominate over sheep and goats, forest destruction proceeds locally rather than generally, the tendency being to restrict the grazing of cattle to the neighbourhood of the settlements, owing to the greater security there afforded from beasts of prey and theft, while swine are rather beneficial than otherwise to the perpetuation of the forest. Pastoral tribes, on the other hand, moving their flocks of sheep and goats from place to place as pasturage becomes temporarily scarce or exhausted, quickly devastate a country, especially under climatic conditions which permit grazing throughout the year, or are productive of summer drought, which latter compels animals to browse rather than graze for their subsistence.

The first stage in the process of permanent deforestation accompanies the cultivation or enclosure of the surface, but before this has proceeded to any great extent, the forests have usually been thinned out to a park-like condition of grass, scrub, and veteran timber tree, picturesque and attractive enough to the ordinary inhabitant, no doubt, but of little commercial value. No succession of young trees exists to take the place of those felled or blown down by wind, the surface becomes hard or covered with grass and rubbish, while wind removes the humus and decaying vegetable matter which formerly preserver the moisture and fertility of the soil. On steep slopes the result of this deforestation is invariably bad, and frequently disastrous, leading to the erosion of the surface soil, the rapid flooding of rivers, and in mountainous countries, to landslips and laying bare of rocky surfaces.

The above sketch, brief as it is, may be said to be fairly typical of the course of events which have taken place 
throughout the civilised world. As regards Europe in particular, one has only to examine the existing state of affairs connected with forests in various countries, and it is not difficult to find results which could only have been brought about in the manner described. In Southern and Central Europe large forest areas are only found in the mountains, where the climatic conditions resemble those of the cold temperate regions farther north. The more mountainous the character of the surface, the more favourable are the conditions for the natural preservation of the forests. In some cases, this may be facilitated by better climatic conditions, such as a heavier rainfall and lower temperature, but the chief reason must be looked for in the more scanty population, the reduced tendency to cultivate or enclose the surface, the absence of winter grazing, and, in various ways, the greater degree in which the balance of nature has been maintained. In Northern Europe forests cannot exist on mountain ranges above a comparatively low altitude, and the larger natural forest areas are chiefly in the lowlands. Here the climatic conditions resemble in many respects those of the mountain ranges farther south, especially as regards winter temperatures. The severe winters of Russia, Sweden, Norway, etc., in conjunction with a comparatively thin population in many parts of them, have had much to do with the preservation of the natural forests. A snowcovered surface during the greater part of the winter renders the grazing of farm live-stock impossible, and limits the number of cattle, sheep, or goats to that which can be preserved by artificial housing and feeding. Summer grazing, when vegetation is in full activity, is less destructive to forest growth than that proceeding throughout the winter, when a deficiency in grass must be made good by browsing on woody growth. Possibly the prolonged survival of the wolf, the greatest natural enemy of 
sheep, groats, and other domestic animals, in the great forests of Northern Europe, has also assisted in forest preservation until recent years, when excessive felling for export purposes may have nullified this and other natural advantages.

Applying the above statements and generalities to individual countries, one is able to connect them more or less closely with the present forest areas found in different states. The early civilisation of Greece and Italy, and the commercial development of Spain and Portugal, have left their mark in reduced and attenuated forests, treeless plains, and a general deficiency in forest production as compared with countries farther north. In the Bilkan States mountain ranges have preserved large forest areas still, but lack of systematic management is doing much to destroy them. Parts of Hungary are comparatively destitute of forests where grazing on the plains has gone on in the past unchecked, while the mountains to the south and east are still heavily timbered. In France and Germany such mountain and hill ranges as the Pyrenees, Vosges, Black Forest, Harz Mountains, Thuringerwald, and various others still show a heavily wooded surface, while the intervening plains and valleys have been devoted more to agriculture and other industries. Still more prominent in this respect is the great Alpine mass of mountains having its centre in Switzerland, and occupying portions of Bavaria, Austria and Italy. On the great plain which stretches across North Germany from the North Sea to Poland, natural forests are scarce south of the 55th degree of latitude, while north of this the influence of a colder winter elimate begins to assert its influence. 'The influence of climates with mild winters upon forest destruction is, perhaps, more clearly seen when the countries bordering the Atlantic Ocean, English Channel, and North Sea are considered in comparison with the 


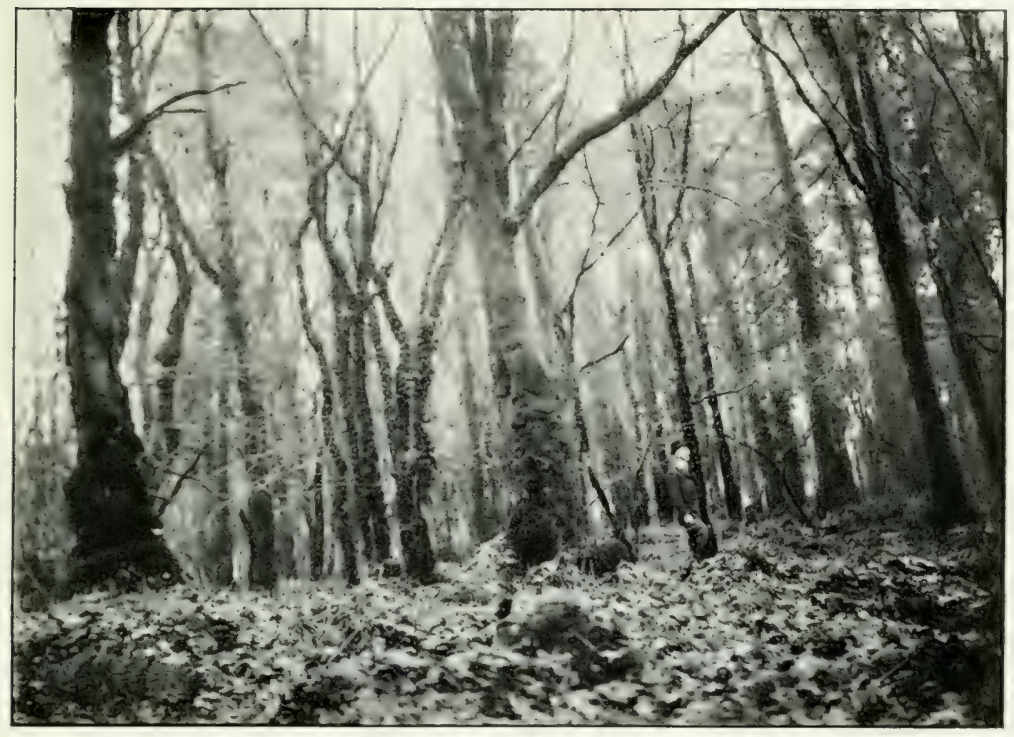

3. Natura1. OAK after repeatei Coppicing.

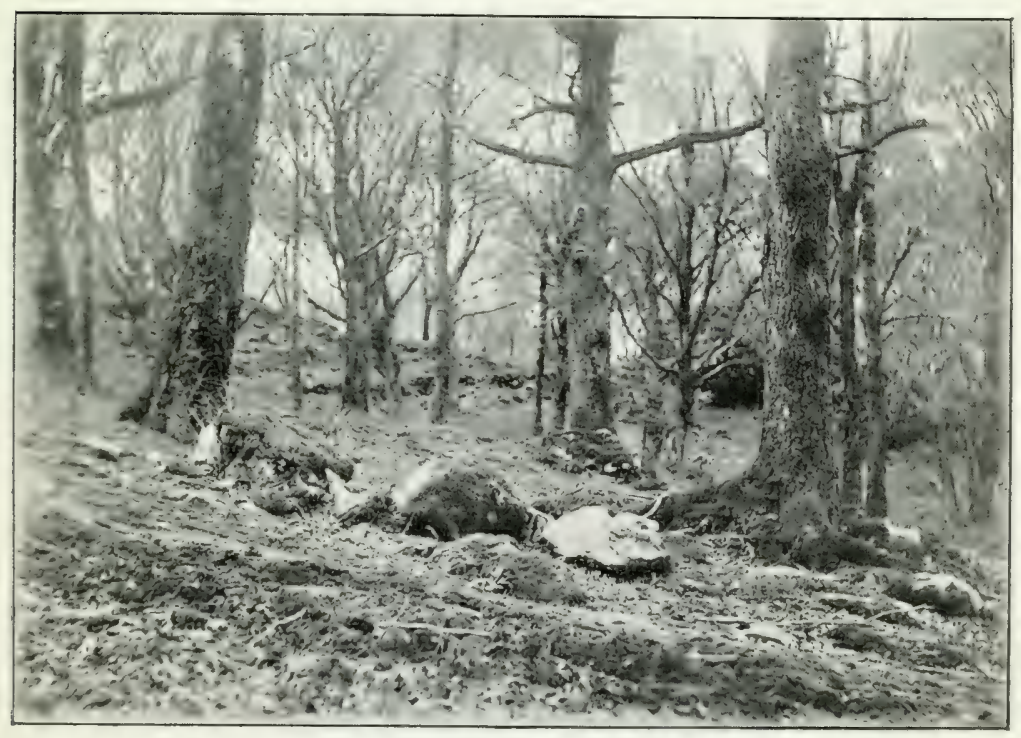

4. OI,1) OAK FOREST IN MOUNTAIN VALLEY. 

remainder of Europe. The western sea-board of France, the British Isles, Flanders, Holland, Schleswig-Holstein, and Denmark are practically the most poorly wooded portions of Europe, and this deficiency was more clearly marked one or two centuries ago than at the present time. In few of the countries comprised in this area did the percentage of forest to total area at that period exceed 5 per cent, although artificial plantations during the last century have raised the area considerably in one or two instances. That this low proportion of woodland is, or was, not altogether due to proximity to the ocean is proved by the remains or evidences of old forests in early periods, which were subsequently destroyed in the manner indicated, viz., by dense populations and continuous grazing, subsequently assisted by wind and sand drifts. Exceptions as regards the former cause may be met with here and there, but very few as regards the latter. The two most striking instances, Great Britain and Ireland, which possess less than 5 per cent. of forest, are also the most westerly, and taking their latitude into account, remarkable for their mild winters.

On the other hand, the most heavily wooded countries in Europe are Northern Russia and Finland, Sweden, and Norway in the north, all characterised by long cold winters, and the Balkan States, Bavaria, Austria-Hungary, etc., in the south, possessing large areas of mountain land with similar winter climates. The connection between natural forests and mountains is, however, brought out more clearly when the provinces or districts of a country are examined. In the German Empire, for instance, the Grand Duchy of Baden, kingrlons of Würtemberg and Bavaria, Thuringia, etc., have over 30 per cent. of land under forest respectively; and the larger proportion of the surface in each is occupied by mountains. In Oldenburg, on the other hand, forests cover 10 per cent.; in Hamburg, 4.3 per cent.; and in 
Bremen, 0.2 per cent., all lying in the North German plain, and bordering on the North Sea. In Belgium, the provinces of Luxembourg and Namur, containing much inountain land in the Ardennes, possess one-half of the entire forest area of the country, while Flanders is practically treeless. In Holland, the provinces bordering the North Sea possess less than 3 per cent. of forest; Limburg, on the Belgian frontier, 17 per cent. These marked differences in the wooded condition of the ranritime parts of Europe today can scarcely be a coincidence, but must bear some relation to the physical and climatic conditions prevailing in each, and the manner in which the surface has been utilised during many generations. Exceptions there may be in many districts, but it will usually be found that they are due to special conditions which have retarded the grazier or the agriculturist, apart from those due directly to great increases in population on limited areas.

As distinct from what inay be termed the natural cause of forest destruction, may be mentioned the more rapid process brought about by the utilisation of the timber at a faster rate than it can be renewed by annual increment and regeneration. The causes already described lead in time to the disappearance of the forests, and their conversion into arable and pasture. The utilisation or destruction of the timber, on the other hand, does not necessarily imply that the woodland is permanently destroyed, provided sufficient seed trees are left for its natural regeneration. As a matter of fact, the two processes often go on simultaneously, and while grazing is preventing the natural regeneration of the forest, the stock of standing timber is being reduced by man for firewood, building, and other purposes. In early periods, forest utilisation was doubtless conducted on a small scale, and had much less effect upon the process of denudation than grazing. As settlements increased in number and size, the more extensive became 
the clearing round about them, until a time arrived when woodland would be valued for the sake of the timber trees it contained, rather than for the grazing its surface afforded for domestic animals. Even here it is possible to differentiate between the value placed upon the timber, and that of the fruit or mast borne by the trees. As late as the eleventh or twelfth centuries, forests in England and many parts of the Continent of Europe were chiefly valued as feeders of swine, deer, etc., and it does not appear that the timber alone was considered of much consequence.

By the thirteenth century, however, there is much evidence that the natural supply of timber in many parts of Europe was not greater than the demand for it. It is, at any rate, about this period that regulations and laws for the preservation of the forests other than those connected with the chase, began to appear. In some cases, as in Switzerland, the object of these laws may have been as much the preservation of the forests as safeguards against avalanches and landslips, as producers of timber, but apart from these instances, a supply of firewood and building timber was undoubtedly the object in view. Thorold Rogers, Pearson, and other antiquarians and historians inform us that timber and firewood in England had reached a fairly high price about this period, possibly as much on account of bad roads for removing it from a distance, as on account of its actual scarcity. Roger's states, for instance, that underwood in the years 1266 to 1385 realised as much as ten shillings or twelve shillings per acre in various comnties of England. He remarks ${ }^{1}$ that 'Wood was of high relative value in the Middle Ages just as it was in Germany.' Pearson, ${ }^{2}$ referring to the same period, states, 'Lastly, woods were so essential to existence that it was an olject with all proprietors to possess them and keep them.' 
The earliest attempts to maintain the balance between supply and demand were in the direction of grazing restrictions, and the prohibition-in communal forests, the manorial wastes, and other forms into which the natural forests had resolved themselves-of indiscriminate cutting for firewood and timber. The number of cattle were either limited, or certain areas of forest closed to grazing altogether for definite periods, so as to allow natural regeneration to proceed, while firewood was usually restricted to dead, damaged, or suppressed trees or windfalls. This may be termed the 'preservative' age of forest management, in which an endeavour was made to restore or maintain the natural order of things without going to the troulde and expense of artificial methods, and was probably fairly extensively in force throughout Central Europe from the twelfth to the fifteenth centuries.

As population increased, and with it the need for larger areas being cultivated or meadowed for the food supply of men and animals, the mere restriction of grazing and fuel rights was found to be inadequate. Without enclosure, absolute safeguards against forest destruction were difficult to uphold, and as the area of natural forest gradually decreasod, the demands made upon the remainder were all the greater. By the sixteenth or seventeenth centuries it appears to have been clearly recognised that the maintenance of an adequate timber supply could only be ensured by the partial or temporary enclosure, or closing, of the forests or woodlands against grazing, and the artificial sowing or replanting of the ground. 'This was the period which saw the commencement of our modern system of sylviculture on regenerative or cultural principles, and may be said to mark a distinct stage in the history of forest development and utilisation in Europe. Down to this period the tendency had been to leave forest production more or less in the hands of nature, merely 
checking abuse or wilful damage by laws and regulations which were possibly not very strictly observed.

This reduction of the natural forest area was, however, obviously imperative, for had it not taken place the improvement or cultivation of the land for agricultural or grazing purposes would have been impossible. But there is good reason to suppose that it went too far in many countries before remedial measures were introduced. A case in point may be found in the British Isles, in which timber-growing for purely economic purposes may be said to have been practically unknown at any time, except on a very diminutive scale. This has been brought about by several causes, but the most important of them have doubtless been, first, the great increase in the population of the country during the last two centuries; second, the development of industries on the one hand, and the breeding of live-stock on the other, which have tended to throw the importance of forestry into the background; and third, the facilities which have existed during the past century for the importation of cheap timber from other countries. Which of these factors has operated most powerfully it is difficult to say, but the fact remains that a forest, in the ordinary sense of the word, and apart from one or two instances, does not now exist in the British Isles. The fertile parts of Great Britain and Ireland to-day present a land surface covered with small holdings, parks, pleasure-grounds, groves, villages, towns, and cities, between which no room exists for such forests as can be found on the Continent of Enrope. Spaces of similar extent in Britain can only be found on the bare hills and mountains, and the question of timber growing on these is one more for the future than the past or present.

For the absence of British forests on a continental scale we must blame partly the alienation of land from the State 
or corporate bodies, and its acquirement by private individuals, and partly the neglect of forestry development in the rural economy of the country two centuries back, due to the causes already mentioned. In the sixteenth and seventeenth centuries, large areas of forest lands, more or less covered with timber, remained in the hands of the State, Crown, Church, or communes, in many European countries, or possibilities existed of resuming possession of them on easy terms. The forests of monastic institutions, ecclesiastical properties, communal lands, etc., were supervised in some form or other with a view to their preservation and systematic administration, and far more cconomic ideas prevailed with regard to the management of private woodlands than was the case with similar areas in Britain, or even those in the hands of the Crown. From the time of Henry vilI. to that of Charles II., a period of about two hundred years, a process of transferring the forests from the Crown to the private individual went on in England and other parts of Britain, partly by grants to courtiers and favourites, partly by sale for the purpose of raising money, while the dissolution of the monasteries in 1540 went a long way towards reducing the stock of woodland in the hands of corporate bodies, until the time came when a mere fragment of forest land remained in other than private hands. The timber on the large areas of manorial wastes or 'commons' was also gradually destroyed by grazing, felling, etc., until these wastes, which were originally forests, consisted of little but open pastures by the time they wore enclosed by various Acts of Parliament. While this destructive process was going on here, the more advanced nationalities abroad, such as France, Switzerland, the German States, etc., were inaugurating a system of scientific forestry which gradually extended from the state, church, and communal forests to the private woods, 
and resulted in a definite recognition of the fact that forests were the heritage of the nation, producers of one of the chief necessities of industrial development, and could not be neglected or destroyed at the whim or pleasure of the individuals who happened to possess them for the time being.

If the above premises are correct, it follows that the value of forests in any country must vary with the density of population, the character of the soil, and the extent to which timber can be imported from abroad at a cheap or a cheaper price than it can be produced at home. Food is a more important commodity in any country than timber, and fuel comes very near it as a necessity of life. A thickly populated country, therefore, with a soil or soils adapted for food production, and an abundant supply of coal, would naturally regard agriculture as a more important branch of rural economy than forestry. The ease with which timber could be imported from abroad would also tend to put home forestry at a discount, and it is not difficult to find excuses for the unconcern with which forest destruction in England, and the mining and manufacturing parts of Scotland and Wales, has been regarded for the last century or two by the general public. Less excuse, however, can be found, perhaps, for its neglect in the north of Scotland, North Wales, or Ireland, in all of which large areas exist unfitted for tillage by reason of soil and climate. But even here extensive grazing has utilised the land in some measure for centuries back, and it cannot be said to be entirely wasted.

In a thinly populated country, with a soil and climate unfitted for agriculture or grazing, and in which fuel can only be supplied from forests, the importance of the latter in the political economy of the country is much greater, especially when the surplus production can be disposed of in a profitable market. The same may be said of a country almost entirely depending for its timber upon 
home supplies, owing to costs of transit raising the value of imported timber to a prohibitive price. Instances of the former can be found in Scandinavia, and parts of Russia, and of the latter in many parts of Central Europe, in which timber can only be introduced by long railway or canal joumeys. It may be the case however, in countries which have only recently acquired a civilised population, that forests are a disadvantage rather than a gain until they have been reduced to their proper proportions. Fifty or more years ago this was probably the case in parts of North America, but at the present day this state of affairs can only be found in a few remote parts of the world, such as portions of South America and Central Africa, in which a tropical climate stimulates forest growth to an extraordinary degree. In Europe, North America, and many other parts of the world the time has now arrived for a definite decision to be made as to the area which must be maintained under forest to supply timber and firewood, and provide suitable social, physical, and economic conditions for the development of every civilised country.

The question as to what percentage of forest to total land surface constitutes an adequate area in any country is difficult to determine, even when all the conditions and circumstances are known. $\mathrm{U}_{\mathrm{p}}$ to the present, a world's timber famine has not occurred, although it has been predicted at one time or another for the last two centuries, while trees for shelter, ornament, soil protection, etc., are adequately maintained in most countries of Europe at the present time. For certain purposes timber is indispensable; for others, sulstitutes can be found for it, and any serious scarcity, causing a rise in price above a certain limit, would be met by a reduced consumption. How far the consumption of timber could be reduced in a prosperous country without interfering with its industries is an 



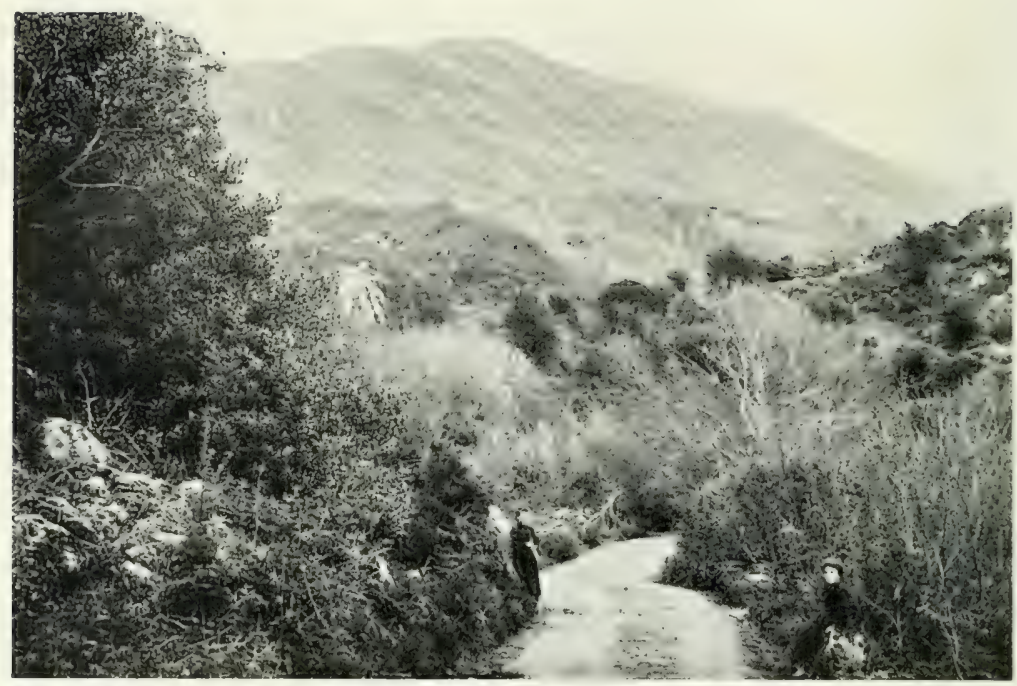

5. Natural Scrub of Ash, Holiy, litr. Killato, by Mry.

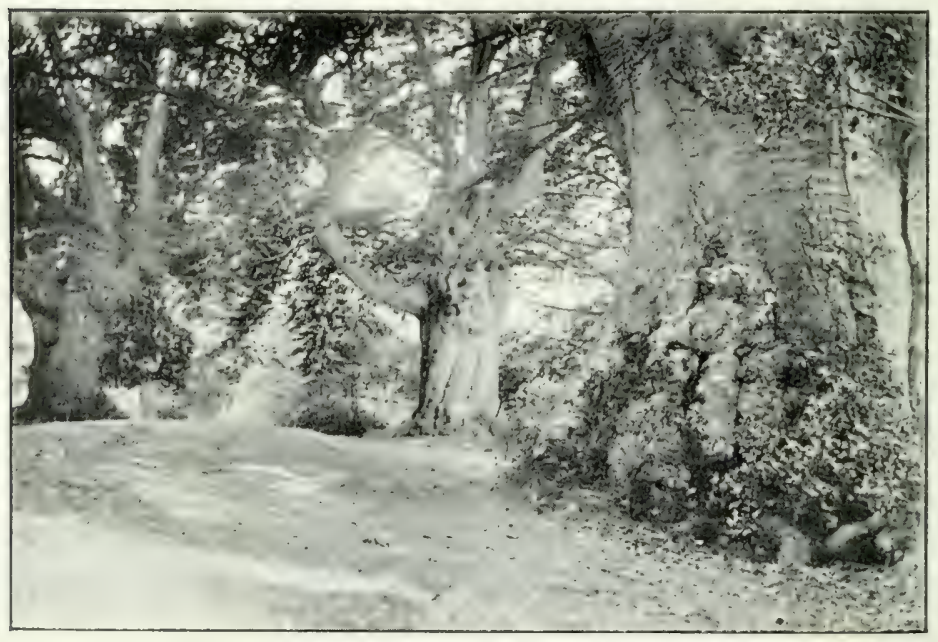

6. Beech Politards. 
important question. Five hundred years ago houses in most parts of Europe were built almost entirely of wood. At a later period stone and brick entered into their construction to as great an extent as timber. At the present time the builder uses steel, iron, concrete, and other materials to such an extent that it is doubtful if a modern city house of six or eight storeys, or a 'sky-scraper' of twelve or fourteen, consumes much more wood in its erection than a manor house or hall of three hundred years back. In shipbuilding much the same change of raw materials has taken place, not to mention other industries of minor importance. Wood pulp, pit props, mining timber, street paving, etc., use enormous quantities of timber, it is true, but for all of these purposes small timber, which can be produced in the course of half a century, can be used, and it is difficult to say what quantity of this class is standing in Scandinavia, European Russia, or Canada, leaving out of account the production of other countries. Countries with numerous and well-developed industries, such as Great Britain, Germany, and Belgium, consume much more timber than purely agricultural countries like Denmark, Holland, or Ireland, or those in which small industries, associated more or less with agriculture are carried on, such as France, Switzerland, Austria, etc. As a matter of fact agricultural, or mainly agricultural countries, are, or ought to be, practically self-supporting in the way of timber, partly because the consumption per head is low, but chiefly because the population has a tendency to remain stationary owing to the surplus emigrating to countries of an industrial nature, or to thinly populated regions out of Europe. Exceptions to this rule may be found where a long period of neglect has reduced the forest area to a low ebb, but even here the imports are, so far as can be ascertained, very small.

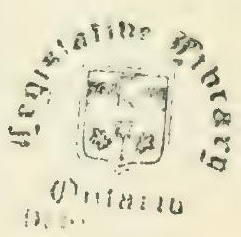


Probably a safe principle for any country to adopt when determining its forest policy is that which will ensure the domestic, or normal consumption of timber being met by the home supply. An industrial country manufactures groods which can be sold or exchanged for other commodities in different parts of the world, and there is no genume reason why timber should not advantageously constitute an import in return for some other produce exported. It appears to be a well-established law in economics that any country which produces more of any particular commodity than is needed for the requirements of its population must possess certain natural advantages which are not found universally over the world's surface. These natural advantages may be represented by minerals, fertile land, good climate, surplus natural supplies of timber, or even skilful workmen and inventive genius. In all cases, however, they eventually lead to a surplus production of some kind or another, and an increase in national wealth above the bare necessities of the people. Without such advantages a country can be little more than self-supporting, and it becomes imperative that all commodities of an indispensable character should be produced at home to avoid national bankruptey or a shrinkage in population. Few cirilised countries at the present day produce all the staple commodities consumed in them, chiefly because certain goods can be produced at a cheaper rate elsewhere, and the land or capital otherwise employed in producing them be more advantageously put to other uses. But it is evident that any article of commerce which cannot be profitably produced by the individual manufacturer or cultivator of any country must sooner or later become scarce, unless the State, or some equivalent administrative body, decides to produce it at a comparative loss, in which case its use will be limited or reserved for home consumption as a matter of urgency or expediency. 
If the matter be carefully examined it will be found that timber is a commodity which, until the last fifty years or so, has been produced by all European countries in sufficient quantities to meet domestic requirements. By 'domestic' is meant such uses as the erection of houses, public buildings, fuel, household goods, implements, and various minor purposes to which wood is put. In recent years, mining, manufacturing, and industrial countries, with a small area under forest, or an abnormal population, have experienced a deficiency, chiefly due to the requirements of collieries, railways, factories, and building extension in industrial centres. Even in such a poorly wooded country as Britain, it is probable that sufficient timber could be grown in existing woodlands to supply the needs of agricultural districts, for it is a well-known fact that large quantities of foreign timber are imported into them more by reason of its well-seasoned and prepared condition, than on account of the actual scarcity of the homegrown article.

But taking a brief review of things as they are found to-day throughout Europe, it will easily be discovered that the fact is being universally recognised that private enterprise will not or cannot maintain a supply of timber which will meet the needs of modern civilisation. In several countries natural advantages exist for favouring the growth of timber without artificial assistance, which have already been referred to, and in these an adequate, or even a surplus supply is still being maintained. But, apart from these, it has either been found necessary to draw upon foreign countries, or to inaugurate a system of State forestry on a larger or smaller scale, according to circumstances. It has been clearly demonstrated that the private owner of land, when unassisted or uncontrolled by the government, invariably fails to ensure, by rational management, a normal yield of timber from 
his woodland, and the general tendency in all privately owned forest areas is first for the timber to be worked out, and second, for the area itself to be reduced by various means. In Germany, for example, the yield of timber from the State-owned forests averages twenty cubic feet, from the private forests only twelve cubic feet, per acre per annum respectively. In nearly all countries, again, a reduction of the private forest area has taken place, except where prevented by law. This process of deterioration in private forests may not be universal at any particular period, and may be hindered or delayed by various accidental or incidental circumstances, but the ultimate result is as stated. It is chiefly due to the long period which elapses between the expenditure and return of any money devoted to forest formation or development, thus placing such transactions outside the class of private investments of a directly remunerative character; and the individual who plants or improves woodlands does so without any prospect of personal profit.

If State action is necessary for the maintenance of an adequate forest area, it will also be found that funds are required to put it in operation. As in the case of the individual, the generation which spends money on this work reaps no direct benefit, and a certain amount of financial sacrifice is involved in the policy in its early stages. Such a sacrifice will only be made with one object in view, that of developing the resources of the country, adding to its wealth, and benefiting a coming generation. This work will obviously be undertaken for the benefit, not of the world at large, but for the particular country in question, and it is possible that a day may come when each country will be compelled to grow its own timber, or pay an exorbitant price for it to the foreigner who happens to possess a surplus stock.

It is, of course, conceivable that certain countries, such as Sweden, Russia, Austria-Hungary, etc., may find it advan- 
tageous to grow timber artificially for export purposes. But while it is probable that a country would lay itself out to supply manufactured or semi-manufactured wood goods, it is extremely unlikely that sufficient round timber of artificial growth will be produced by any country in excess of its own manufacturing requirements. Even now, when practically all the timber exported throughout the world is of natural growth, the tendency is to manufacture it as much as possible, and there is little doubt that tendency will increase rather than decrease, especially in countries in which the facilities for developing industries are limited, and the surplus population finds a difficulty in obtaining any kind of employment. In short, free trade in round timber is not likely to continue for many more years, unless an energetic policy of forest organisation and reproduction is inaugurated throughout the civilised world, and the timber supply maintained at more or less its normal level.

If the above statements are correct, and every source of information points to their being so in a general way, three questions naturally present themselves: (1) What must be considered the nommal domestic consumption of timber per hearl of population in Europe generally? (2) Is the existing forest area sufficient to meet that consumption? and (3) Can a deficiency of home-grown timber, clue to the development of inchustries, or increase of population in one European country, be met by an excess in another?

To estimate the normal domestic consumption of timber, it is necessary to take a country which is more or less stationary as regards population, which supports itself in food, clothing, fuel, housing, etc., by the cultivation and utilisation of its soil, and which has fully developed all its natural resources so far as national wealth and general prosperity are concerned. 
Strictly considered, such a country can scarcely be found at the present day, for none is absolutely stationary in population, self-supporting in the necessities or luxuries of life, or fully developed in all possible directions. But by taking the average density of population throughout Europe at the present day as being more or less stationary, owing to rural depopulation and emigration to other parts of the world, it is seen that some $400,000,000$ inhabitants are sharing an area of about 3,800,000 square miles, or an average of 100 head per square mile, or 17 per 100 acres. This density approximates closely to the conditions found in Spain, Servia, Greece, Roumania, Bulgaria, and other countries in the south of Europe, with a population chiefly devoted to agriculture, grazing, etc., but without important industries of other kinds. From the fact that none of these countries requires to import timber to any considerable extent, it may be assumed that they are practically self-supporting in that commodity, although no figures are available to show exactly what quantity is consumed in them. But it must be noticed that this density of population is lower than that of countries farther north, until the 55th degree of latitude or thereabout is reached, when it falls much lower than this in Norway, Sweden, Russia, etc.

Probably such countries as Switzerland, Denmark, or Ireland enable an estimate to be formed of home consumption on a normal scale better than most, as the production of wood, or area of forest land in all these countries is known with comparative accuracy, while their natural agricultural resources have been developed to the greatest possible extent. The population of Switzerland is about $3,500,000$; the area under forest about 2,000,000 acres, estimated to produce annually some 7,500,000 feet of commercial timber, or about 2 cubic feet per head. Switzerland exports approximately the 
same quantity of timber as she imports, but requires to import fuel to the extent of over 200,000 tons $(10,000,000$ feet), making a total consumption of about 5 cubic feet per head. The population of Denmark is about 4,000,000 ; and the home supply from about 400,000 acres of woods under a proper rotation of cropping is estimated at 175,000 loads or $9,500,000$ feet, to which about 500,000 loads or $3,000,000$ feet of imported wood may be added. This gives a consumption per head of just over 3 cubic feet per head, exclusive of firewood, poles, etc. Ireland, with a population of $4,500,000$, and a smaller proportion of land under timber than any country in Europe, imports about 300,000 tons on an average of years, and exports about 100,000 tons of pit wood. The nett import, therefore, does not greatly exceed 2 cubic feet per head.

Allowing for inaccuracies in these cases in either direction, it may safely be said that the domestic consumption of a purely agricultural country does not exceed 5 to 10 cubic feet per head annually, apart from firewood, poles, and small wood which can be obtained from scrub forest, or the thinnings and refuse of high forest. This consumption can be met by the systematic maintenance and economic management of about one-fifth of an acre of properly worked forest on good land per head of population, but on an average of soils and situations would probably require one-fourth. The actual area of nominal or estimated forest in Europe at the present time is about $700,000,000$ acres, equal to $1 \frac{3}{4}$ acres of forest per head; but as this forest area does not consist entirely of productive or timber-producing land, it would be safer to say that the acreage of forest is about equal to the population, and is in excess of the actual domestic requirements in most countries, excepting those lying along the western sea-board. Of these, Great Britain shows the greatest deficiency, for with a population of about $40,000,000$, she possesses a 
woodland area of but 2,750,000 acres, or a little more than one-sixteenth of an acre per head.

The ruestion of greatest inportance, however, is that deal. ing with the abnormal consumption of timber for inrlustrial purposes, such as mining, railroad buildingr and maintenance, and the numerous industries connected with the housing. feeding, and clothing of a large manufacturing population. Here, again, Great Britain afforls the most striking example of a country requiring large quantities of timber in excess of the purely domestic consumption. According to the Boarr of Trade returns for 1905, Great Britain importerl 9,200,000 loads of round, hewn, and sawn fir, oak, and other timbers, of which 7,600,(0)0 loarls caure from Scandinavia, Russia, Austria-Hungary, Germany, etc., and the remainder from Canada and the United States. Of this quantity, about one-third consisted of pit woorl, while pulp woor, paper, etc., represented an additional $2,000,000$ trons, making a total import of about $12,000,000)$ tons, exclusive of tropical woods and manufactured articles. In 1907, Germany imported about 6,000,000 tons of the same class of timber from Europe, and about $250,(000)$ tons from North Anerica. Belgimm imports, on an arerage of late years, about 1,500,000 loads, France about 3,000,000 loads, each load probably being the equivalent of 2 tons of green wood in the round, or about 60 cubic feet (over bark quarter girth measure).

Allowing for miscalculations and omissions, therefore, the total imports of timber, exclusive of manufactured articles, into the chief industrial countries of Europe, amount to about 25,000,000 loads, or the anmual average produce of $50,000,000$ acres of well-managed high forest on good land. Of this quantity, probably four-fifths come from other parts of Europe, leaving 5,000,000 loads as the contribution of North Anerica-a practically insignificant quantity. 
An important point to discover, however, is the possibility or impossibility, as the case may be, of the nonmanufacturing or forest-owning countries continuing in a position to supply the needs of their industrial neighbours. Prophets are not wanting who predict a shrinkage of imports at no distant date, but the probability is that no one is in a position to state authoritatively that this is inevitable. As regards the nominal forest area of Europe, it has been shown that this is sufficient to meet the domestic requirements of about four times the existing population, assuming that not more than onethird of the area is probably scrub or non-productive. How far the industrial requirements of some half-dozen countries are likely to increase it is impossible to say, but various circumstances point to the probability that they have reached their limit in a general way, and that the excess consumption of timber over the normal quantity used by agricultural communities will not exceed from $25,000,000$ to $50,000,000$ tons during the next halfcentury.

It is clear, therefore, that the nominal forest area of Southern and Central Europe is sufficient to meet all reasonable requirements, and that the excess production of the more heavily timbered lands could, under proper management, make good any deficiency elsewhere, except in such countries as Great Britain, Germany, Belgium, etc. Whether they can make good this deficiency in the future depends very greatly upon the policies adopted towards forest alministration, organisation, protection, and regeneration in the various countries comprised in the area in question. At the present time, progressive afforestation of available lands, and careful maintenance of existing woodland are going on in Demmark, Germany, France, Belgium, Holland, Switzerland, and to some extent in Austria-Hungary, and other countries, 
which together contain about one-third of the population of Europe. Spain, Bosnia, and Herzegovina, Roumania and Creece possess large areas of State forests, which are probably under some form of protection, and in the event of their further industrial development, will be properly administered. The effect of this movement upon the home timber supply of these countries in general must be considerable within the next fifty years, especially as regards the quality and yield of commercial timber per acre. In Germany, for instance, out of a total forest area of $34,000,000$ acres, about $12,000,000$ acres are stocked with trees not more than forty years of age, and $9,000,000$ acres between forty and eighty years of age. ${ }^{1}$ This would indicate the probability of the present estimated yields of the German forests, 20,000,000 tons, being largely increased in the future. A similar preponderance of comparatively young crops in most of the other countries mentioned above may be observed, due to the increased activity in afforestation during the last half-century, and there is no indication at present that this activity is likely to decrease, but rather the reverse. While, therefore, the home timber supply of several countries may be unable to meet the whole of their present or future requirements, it is possible that the deficiency may not greatly increase on the whole, whatever the position of particular localities may be, owing to industrial development.

But apart from the position of the more thickly populated portions of Europe as regards timber production, there can be no question that Northern Europe possesses a forest area greatly in excess of its actual requirements, and capable of exporting, under proper management, the greater part of the timber needed in thinly wooded countries for all time. Between the Arctic Circle and the 55 th degree of latitude a belt of land exists which may, in a comparative sense, be regarded as a vast forest.

I Statistisches Jahrbuch für das Deutsche Reich. 1908. 
In spite of immense areas of barren rock, swamp, and waste, Russia, Finland, Sweden, and Norway contain an area of estimated forest land somewhat exceeding 500,000,000 acres. Throughout this vast tract of country the population probably does not exceed on an average 50 head per square mile, while domestic cattle are equally scarce. The importance of this forest belt to Europe generally, and Great Britain in particular, probably lies less in the actual stock of timber it contains, or the quantity it exports at the present time, than in the fact that it is essentially adapted by Nature for timber-growing, and for very little else. Long, severe winters, rocky and uneven ground, and the inaccessibility of a large proportion of its surface to the ordinary trader or merchant, practically preclude the possibility of agricultural or industrial development, except, perhaps, in a few mining centres. This fact is of special importance in connection with present or future planting operations on a large scale in this country, and more particularly when it is taken into account that spruce and Scots pine form the bulk of the timber grown in Scandinavia and Northern Russia, and these, or closely allied species, can alone be used on poor land in Britain. Fire, reckless cutting, and a general neglect of regenerative measures may imperil the productivity of this natural forest area for a time, but sooner or later, as its value as a national asset becomes more clearly recognised, more effective measures for its perpetuation will be formed, and, as a matter of fact, much in this direction has already been accomplished.

The answers to the questions propounded above may, therefore, be generally answered as follows :-

1. The annual domestic consumption of timber per head of population in any country may be roughly estimated at 5 to 10 cubic feet, or the average yield of from one-fourth to one-half of an acre of forest under systematic management. This quantity is exceeded in 
countries dependent upon wood for fuel, but in such cases, scrub and refuse timber assist in making good the deficiency.

2. The estimated forest area of Europe is more than sufficient to meet the normal demand for timber. Certain countries possess too small an area to meet their industrial requirements, but of these Great Britain and Belgium appear to show the only serious deficiencies, amounting to 10 cubic feet of coniferous timber per hend in the former, and 8 cubic feet per head in the latter.

3. The area of forest land in Northern Europe can, if ardequately protected and properly managed, supply the requirements in coniferous timber of manufacturing, mining, and thickly populated countries, provided their consumption does not exceed a total import of more than 50,000,000 loads per annum during the next halfcentury.

The above conclusions are, it need scarcely be stated, based on the probability of the development of forestry throughout Europe generally, on the same lines as have been followed in Germany, Switzerland, Belgium, Holland, Denmark, etc.

A point of further importance in this connection is that a country uses timber in proportion to its facilities for getting it. Russia, Norway, Sweden, Canada, and the United States are familiar examples of countries which use enormous quantities of timber, and have a very high consumption per head, simply or chiefly because the timber is found in abundance, and is the cheapest article that comes to hand. Fuel, buildings, waste, and fire now consume vast quantities of timber which could be saved by a more economical system. Where fuel cannot be obtained or imported at a cheap rate, wood must always be consumed on a large scale; but, apart from fuel, other purposes for which wood is often used can be supplied ly various materials. 
While great stress has been laid upon the increased total and per copitu consumption of timber, the fact that all well-managed forests can yield four to five times as many cubic feet of big timber as those left to nature is overlooked. The United States Forest Department calculates that the present yield from American forests is not more than 12 cubic feet per acre per annum, whereas the average for the whole of Germany is nearly 50 cubic feet of timber and firewood.

As regards the area of European forests, Endres ${ }^{1}$ believes that this has not altered more than 2 per cent. within the last century. While a few countries have shown a decrease, others, and notably Germany, have shown an increase. Much more important than actual area, however, is the higher yield of timber produced by forests under systematic management and worked under the high forest system as compared with those left entirely to nature or simply coppiced from broad-leared species. How great this has been in Germany within the last hundred years may be gathered from the following figures given by Endres, ${ }^{2}$ and showing the nett cash yield per hectare since 1820 in the following states :-

1820.

\begin{tabular}{|c|c|c|c|}
\hline Prussia, & . $\quad(4: ?)$ & Larks. & 13 Mark \\
\hline Bavaria, & $4 \cdot 7$ &, & $19 \quad$, \\
\hline Saxony, . & 9 & ., & $51 \cdot 7$, \\
\hline Würtemberg, & $5 \cdot 7$ & $"$ & $33 \cdot 3$, \\
\hline Baden, & . $(12 \cdot ?)$ & , & 32, \\
\hline
\end{tabular}

These increases are chiefly due to the higher yields of timber, as in Saxony the percentage of timber to total produce has increased from 17 per cent. in 1820 to 80 per cent. in 1890 , above which it is scarcely possible for it to go.

In a general way the cubic yield of most of the State forests in Germany has been doubled within the last fifty 
years. Endres states that the yield in timber from the Saxon State forests was 459,953 cubic metres in 1850 , and 832,2:32 cubic metres in 1888, the increase in area during that thirty-eight years being but 50,000 acres. As Mayr also remarks, ${ }^{1}$ the annual yield of German forests has increased from $10-20$ to $40-50$ cubic feet per acre, in spite of the dangers from frost, wind, insects, and fungi incidental to pure crops grown on the high forest system.

An increase in yield, corresponding to that in Germany from the whole of the European State forests alone, would bring the production of timber to at least double that of the present time, and would leave very few countries in a position of dependence upon their neighbours, except for timber which they could not produce at home, or for pulp wood obtained from the natural forests of the north.

No doubt a temporary shortage of timber is likely to occur in some parts of Europe and America, but it need not necessarily attain the dimensions of a famine, unless economy and common-sense are alike ignored. The price of timber is bound to rise, however, to a fairly high level, and this alone will tend to greater economy in its use on the one hand, and a greater tendency to increase the cultivation of it on the other. This, however, is no good reason for embarking upon reckless planting schemes on land which can never be expected to produce more than scrub or small timber, a class of produce least likely to share in any rise in value in the future.

\footnotetext{
1 Waldbau auf naturgesetzlicher Grundlage.
} 


\section{CHAP'IER II}

THE FOREST REQUIREMENTS OF THE UNITED KINGDOM

THe position of Great Britain and Ireland as regards timber production on the one hand, and timber requirements on the other, has long been a favourite subject with forest economists. With practically the lowest percentage of the total land surface under woodland, and the highest consumption of imported wood per head of population, the development of the existing forest area, and its extension on land not needed for intensive agriculture demands serious consideration.

In the six years, 1904 to 1909 , the total value of timber-manufactured, hewn, and unenumerated, etc.averaged, according to Board of Trade returns, just under $£ 25,000,000$. In 1906 its value was $£ 27,507,410$, and in 1909, £23,591,810. The nearest approach to the average was in $1908, £ 24,306,169$. In the latter year the chief items were:-

Loads.

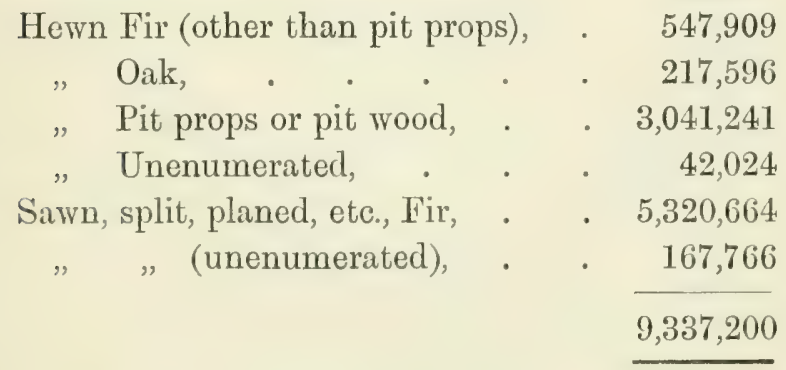

It is seen that more than one-half of the total quantity 
consisted of sawn or dressed timber, while 456,000 loads, consisting of staves, furniture woods, etc., are not included. The nett imports of unmanufactured timber which might be grown in the British Isles was, therefore, 3,848,700 loads, of which pit props constituted over $3,000,000$ loads. Of the sawn or dressed timber, almost 4,000,000 loads came from Russia, Sweden, France, and Germany, and the bulk of the remainder from Canada and the United States of America. The greater part of this, again, might be considered as producible at home if the land were available, while wood pulp to the value of over $£ 3,000,000$ was imported in 1908, which may also be considered as capable of home growth.

If, however, these imports can be maintained from Russia, Scandinavia, and Canada, the question of timber consumption and production is very largely one of finance. It is practically certain that these imports will rise in price until they reach a figure which will cover artificial costs of forest protection and cultivation. While timber, as any other commodity, fluctuates in price, the general tendency of late years has been an upward one-first, because it has to be procured at greater cost as it is obtained at greater distances from ports or rivers, and second, because the cost of protection and regeneration of forests must be incurred, and paid for by the timber sold. Judging from present appearances, this increase will chiefly apply to the larger dimensions of logs and scantling, and least affect such sizes as those used for pit props, pulp wood, etc., as thinnings and the yicld of inferior soils and localities can be utilised for these purposes, while their transport over rough ground can be more easily effected. Moreover, it is this larger class of timber which will, sooner or later, be reserved for home consumption in countries which are not entirely given up to absolute free trade, and there is little doubt 
that some form of export duty will be put upon it in the round or unmanufactured condition.

It becomes all the more important, therefore, that Great Britain should ensure a supply of such timber as is now being produced throughout Germany and other countries owning State forests, which latter are worked on longer rotations than the private individual finds profitable in ordinary circumstances. To produce the whole of this class of timber now required at home is practically impossible, unless an area is devoted to that purpose which would seriously interfere with agriculture, for it is only upon agricultural land that first or second class timber can be grown in Britain. But it should become a settled policy in the administration of the country that a forest area, capable of producing first-class timber in sufficient quantities to meet the requirements of the staple industries of the country, such as agriculture, housebuilding, and the numerous minor industries associated with civilisation, should be gradually formed and maintained. What exactly this area should be is a question, but if the population found upon three-fourths of the British Isles be taken as the natural stock which has been created by the normal development of its agricultural resources, independently of minerals and colonial intercourse, a forest area sufficient to meet the needs of about 20,000,000 would be required, representing a density of about 200 head per square mile, or 30 to 40 per 100 acres. Basing the requirements of this population in hewn and sawn timber on the estimate of 5 to 10 cubic feet per head, or one-eighth of a load $(=60$ cubic feet of round timber), an annual supply of 2,500,000 loads would have to be grown on about 5,000,000 acres of good forest land, supposing the ground were sufficiently good to produce 30 cubic feet of first-class timber to the acre. But to allow for waste, roads, margins, and fences, con- 
tingencies due to wind, insects, fungi, etc., an additional million acres would probably be required in actual practice, and required in the form of comparatively large blocks. Such an area would produce from one-half of a ton to a ton per acre of poles, branch wood, and inferior timber, in addition to that already estimated, and would probably produce about one-third of the total quantity of timber, manufactured or unmanufactured, used throughout Great Britain, exclusive of teak, mahogany, and other woods of that description.

As the acreage already under timber trees in the British Isles is 3,000,000 acres, it is a question how much of the quantity of timber required is, or can be produced from existing woodlands, and how much from additional forest. No returns are made of home supplies of timber, but it may be assumed that the yield per acre is very low, owing to the small and scattered character of a large proportion of the woodlands, and the indifference displayed in their management as timber-growing areas. At a rough estimate, however, 2,000,000 acres might reasonably be assumed to exist under such conditions as would enable them to produce their full share of good timber, leaving the remaining third as belts, clumps, small woods, and ornamental plantations, which would fulfil many useful functions in addition to furnishing something in the way of timber. If this estimate is accepted, it follows that an addition of $4,000,000$ acres is required for economic timber-growing, and the agricultural or grazing land of the country must be diminished by that area. This would give the British Isles a total forest area of $7,000,000$ acres, equal to about 10 per cent. of the land surface of the country, and still below that of other European countries, except Portugal, Holland, and Denmark.

The question may naturally present itself, 'Why 
should the production of large timber constitute the main function of the forest policy of Great Britain, when pit wood, pulp wood, etc., form such a large proportion of the national and industrial requirements?' This question has already been partly answered, but the most convincing part of the answer may be found when the geographical position of the British Isles is considered, in connection with that of the areas from which pit and pulp wood are now obtained, and the condition of the timber stock on these areas. At the present time, the forest belts of Northern Europe and Canada supply practically all of these forms of timber, both of which are within a few days' sail of the British Isles. The transit facilities for obtaining timber from these two regions are as good, if not better, than those existing for a railway journey of 100 miles within the British area, and it is difficult to see how a combination of sledging, floating, and sea carriage, when applied to enormous quantities of timber, can become much dearer per ton to consuming centres than that of smaller quantities of timber from inland situations in Britain. A leading Scottish timber merchant recently stated that timber could be delivered in Aberdeen from St. Petersburg, 400 miles distant, at the same cost as from Deeside, 40 miles distant. If these transport conditions remain as at present, the question becomes one of continued supply more than anything else. Spruce probably forms 90 per cent. of the pulp wood, and 75 per cent. of the pit wood used in Britain, and also forms the bulk of the forest growth in the timbered areas of Europe and Canada. As already stated, about 500,000,000 acres are under this class of forest north of the 55th degree of latitude in Northern Europe, while within the same or slightly lower latitudes in Canada it is estimated that some 60,000,000 acres of forest, chiefly composed of spruce and pine, exist 
in the three eastern provinces of Quebec, Nova Scotia, and New Brunswick, while Newfoundland possesses about $10,000,000$ acres all within easy sea carriage of Britain.

The following details regarding Canadian forests are given in the Canadian Annual Review for 1908:Dr. Bell, Assistant Director of the Canadian Geological Survey, estimates the area of the northern forest of Canada at 1,657,600,000 acres. This belt of forest area is chiefly stocked with black and white spruce, and would yield $16,500,000,000$ loads of spruce. It is stated that spruce reproduces itself sufficiently fast to produce pulp wood in thirty years, while the present stock of timber would meet the existing lemand for pulp wood for the next fifty years. Another estimate puts the total area under spruce alone in Canada at 450,000,000 acres. According to $\mathrm{Mr}$. B. G. Fernow, the area of commercial saw timber in British Columbia probably does not exceed $50,000,000$ acres, and about the same in the Atlantic Provinces. This survey did not touch the great northern belt of forest, as to which all is more or less conjecture. Mr. R. H. Campbell, Superintendent of Forestry, in his annual report stated that the inquiry made by a committee of the Senate during the past session showed that the natural resources of the northern districts of the West are greater than the public has any idea of. In the near future, the whole eastern slope of the Rocky Mountains will be established as an inalienable Forest Reserve, while in Quebec 108,000,000 acres were placed in Forest Reserves during the past four years.

How far these estimates may be correct, and how much of the existing crop may be destroyed by fire, none can say. Everything points to the fact, however, that vast areas of natural timber land exist in Canada at the present day, and that the purchase of land for, and expenditure of money in, planting spruce for pulp wood alone 
in the British Isles is a somewhat risky speculation, unless a high protective tariff on imported pulp is to be imposed in the future.

Dealing with Scandinavia, enormous stocks of coniferous timber are reported by various authorities. According to Sundbarg, the total forest area of Sweden extends to 52,000,000 acres, of which $12,000,000$ acres consist of Crown parks (State forests), while 6,000,000 acres are either held by the State, or leased to saw-mills, mines, public bodies, etc. Vast areas are held by hundreds and parishes, and these forests are also under State control, and the proceeds from sales of timber are devoted to the support of schools, churches, public works, and other purposes. Since 1903 Forest Conservation Boards have controlled the private forests, and the expenses of these boards are covered by export duties on round or unmanu. factured timber, amounting to about one penny per cubic metre. The Norrbotten Law prohibits the felling of trees in Northern Sweden having a diameter of less than $8_{4}^{1}$ inches at 15 feet from the ground. Between 1875 and 1900 about 600,000 acres of forest land were purchased by the Swedish government, and this work is still going on at a rapid rate.

But the most reliable evidence regarding the forest resources of Sweden is that of Dr. Metzger, Professor of Forestry at the Forest Academy at Munden, who visited Sweden in 1909, and whose impressions are given in the Allyemeine Forst. und Jergel. Zeitung for January 1910.

Amongst many interesting facts regarding the forests of Sweden, Dr. Metzger states that Norrbotten, the most northerly district or province, and the most important from a timber-producing point of view, possesses a population equal to one person per square kilometre. This province has about 75 per cent. of its total area under

1 Sweden: Its People and its Industry. 
forest, representing more than one-half of the whole Sivedish forest area, while 51 per cent. is in the hands of the State. Not only the Crown parks, but many of the forests owned by large saw-mill companies, landowners, etc., are carefully managed and fully stocked, while even reckless cutting has failed to permanently injure many of the private forests, so successful is natural regeneration under the existing soil and climatic conditions. It was estimated by a coinmittee appointed to investigate the forest resources of the country a few years back, that the consumption of wood amounted annually to 29,000,000 cubic metres, or about 20,000,000 tons of round timber. This was made up as follows:-

Cubic Metres.

Domestic purposes, $15,853,000$ Export, $6,130,000$ Pulp wood, $1,419,000$ Mining timber,

$5,687,000$

$29,089,000$

The estimated annual increment on the entire forest area was put at $34,500,000$ cubic metres. Since that estimate was made, the export and pulp wood consumption has risen by about 5,000,000 cubic metres.

Dr. Netzger, in referring to the estimated annual increment, states: 'According to my opinion and observations, I am inclined to agree with those Swedish foresters who put the valuation at a higher figure. Basing the estimates on the data supplied, it appears that the yearly consumption does not exceed 1.6 cubic metres per hectare. This must, with proper management, be easily produced by the forest area, even when the low productivity of the most northerly part of the country is considered. The greater part of the Swedish forests lie in 
districts that may be calculated to produce at least from $2 \frac{1}{2}$ to 3 cubic metres per hectare per annum.'

In European Russia there are, according to a consular report (1907), 228,973,000 acres of State forests. In the consular district of St. Petersburg alone, 204,000,000 acres of forests exist, while forests are said to stretch in a broad belt across the whole length of Siberia. In such a vast area it is obvious that many forms of management or mismanagement may be met with, but all evidence points to the fact that the timber resources of this enormous country are, with the systematic management that is being gradually introduced, practically inexhaustible.

In Finland nearly $40,000,000$ acres of forest exist, $13,000,000$ of which belong to the government. Finland has a population of only $3,000,000$, spread over an area of about $60,000,000$ acres, equal to 5 per 100 acres. The present export of timber (1907) is, according to a writer in the Timber Trudes Journal, about 2,000,000 cubic metres, or a little over $1,000,000$ tons. An export tax is placed upon unmanufactured wood, as in Sweden.

Apart from private forests, and those owned entirely by private companies, etc., there would appear to be an area of at least 300,000,000 acres of forest in European Russia, Finland, Swerlen, and Norway, owned by the state, corporations, cominunes, etc., all of which have adopted, or certainly will adopt at some time or other, a policy of forest conservation. If the future annual yield from this area is put as low as one-fourth of a ton per acre, a possible annual output of at least $70,000,000$ tons is secured, leaving out of account the timber obtained from $200,000,000$ acres of private forests, which cannot be inconsiderable in countries in which compulsory upkeep of forests is enforced in some form or another.

Of parts of the Quebec forest area the following statement was made by a Crown official in 1882:- It is 
evident, therefore, that by far the greatest portion of this vast forest region of upwards of 177,800 square miles in area, fit for nothing else, must remain a timber forest for ever, increasing in value as timber becomes more scarce elsewhere; though capable, nevertheless, of maintaining a sparse but hardy population in comparative comfort by the development of the resources of its mines and of its forests, if cared for and preserved.' It is probable that the same remark might be applied to the greater portion of the total area referred to above, both in North America and Europe, proving that within a few days' sail of Great Britain a forest area covered, more or less, with pit, pulp, and building timber will be available for meeting the requirements of Great Britain for centuries to come, provided regulations against reckless felling are enforced, and protection against fire afforded. In view of the present attitude towards forest conservation generally throughout the civilised world, it is unlikely that forest destruction in Northern Europe or Canada will be allowed to proceed too far. Sweden has already taken steps to prevent the felling of small or immature timber. Russia and Finland have done something in the same direction, and it is practically certain that the example set by the United States in forming forest reserves will be followed more extensively by Canada sooner or later. Many of the larger timber and pulp wood companies now own vast areas of forest which they have put under more or less systematic management, and the supply from these will probably be maintained, and eventually increased.

It is more than probable, therefore, that the supply of small coniferous timber from easily accessible countries is sufficient to meet present requirements in these Islands; while, as regards the future, Canada, Scandinavia, and Russia enjoy natural advantages for the continued produc- 
tion of such timber which are not found in Great Britain or Ireland. For the latter countries to inaugurate a forest policy, which has for its primary object the production of third and fourth rate spruce and Scots pine timber, at a far greater cost per load than that incurred by the principal countries of export, appear's to be a very questionable procedure. As will be shown in a later chapter, an extensive aftorestation of mountain land, the only class likely to be available on a large scale in the United Kingdom, could only be accomplished at a relatively high cost, while the yield from such land could, under the existing soil and climatic conditions, be but comparatively small in quantity, and inferior in quality. Only by the afforestation of the poorer classes of agricultural land, with perhaps a certain proportion of the better class of grazed mountain, could timber of sufficient size and quality be produced to enable the cost of production to be repaid, and the most urgent requirements of the country to be met. Even in the event of a shortage in small timber within the next forty or fifty years, it is obvious that such a shortage could not be made up by increased afforestation in a shorter period than half a century on the poorer land in question, and if afforestation is necessary at all for such a purpose, it is equally important that the period of production should be shortened as much as possible. Little could, therefore, be gitined from the expenditure of large sums of money in the planting of inferior soils, beyond what is desirable for the improvement of social and residential conditions in hill districts.

The following article on the commercial aspect of aflorestation appeared in the Timether Trenles. Journul of February 6, 1909, and has such a close bearing upon this subject that it is worth reproducing in full :-

This important question, which is gradually forcing 
itself to the front in the United Kingdom, has hitherto been regarded by the majority of our citizens as of too abstruse a nature to enlist more than an academic sort of interest. So long as the shoe does not pinch, people are naturally not inclined to think too seriously about the possible effects of a scarcity of timber some twenty-five or thirty years hence. The practical man, however, is aware that the question is too serious to be dismissed with a shrug of the shoulders, and the following remarks from the pen of one actively engaged in the timber trade of the north of Europe, who has had ample opportunity of forming a judgment as to the present condition of the furests on the Swedish side of the Scandinavian Peninsula, may not be without interest.

'Before expressing a definite opinion as to the condition of the Swedish forests and the influence these may be expected to exert on the financial result of the proposed planting of denuded areas in the United Kingdom, it is necessary to look back for some decados. It must be understood that, prior to the reduction of the import duty in 1842 in this country to 30 s. per load for sawn and $24 \mathrm{~s}$. for hewn wood, growing wood in Sweden had a mere nominal value as a realisable asset. The effect of this was that very little care was exercised in its conservation. The Swedish saw-mill industry as we know it may be said to have had its inception after the reduction of the duty on foreign sawn and hewn softwoods in 1851 to 10s. and $7 \mathrm{~s} .6 \mathrm{~d}$. per load respectively, a further fillip being given to the industry when the British duty was reduced to a nominal amount in 1860 , prior to its total abolition in 1866. It was not till after the Crimean War that any appreciable quantity of building timber was shipped to European countries other than Great Britain, the price then and for several years after being practically set by the market in the United Kingdom. 
'In addition to the waste of wood, consequent on its low value, prior to 1856 , the practice of landowners granting long leases of their forests from about that time had a disastrous effect on the Swedish woodlands. The usual length of lease at that time was fifty years, and as the leases then covered only the heavy timber, it can be readily understood that the lessee was not at all careful to conserve the smaller growing trees, which were not included in his lease, and which had then practically no value. It was, however, soon recognised that these long leases had a very bad effect on the forest, and the legal length of same was gradually reduced, until at the present time five years is the maximum, and even then the lease is subject to the provisions of the Replanting Law. The mischief had, however, been done, and as many of these leases in the provinces of Norrland and Dalecarlia (which supply more than four-fifths of the building wood shipped from Sweden) have only lapsed during the last few years, it is evident that the ground covered by them is now in a partially denuded state, as the lessees naturally took good care to cut out their wood before handing the ground back to the owner. During the last fifteen years a great change has, however, come over the scene, many of these denuded or partially denuded areas having been bought up either by the wealthy saw-mill companies or by the Swedish Forest Department. As the enhanced value of these forest linds became apparent, there was such a rush by the saw-mill companies to secure sime that the Swedish legislature a lew years ago, apprehensive lest the class of yeomen farmers that owned the bulk of them would be entirely submerged, passed a Bill practically prohibiting all further acquisition of forest lands by the big saw-mill companies. In many districts these saw-mill companies and the State together own more than half the woodlands, and as the former now have to make shift to obtain 
the bulk of their raw material from own woods, they have become much more careful of them. For the above reasons it may be taken for granted that a large part of the Swedish forests are in a state of transition, and are at present suffering from the effects of the gross waste which obtained in the sixties and seventies. It would, however, in the writer's opinion, be imprudent to infer that we are likely to witness a timber famine in Sweden, although it is probable that the quantity of building wood of Scots pine and spruce shipped from that country will have to be reduced for a time.

'The total area of the Swedish woodlands is estimated at about 52,412,000 English acres (equal to about 51 per cent. of the total area of the country), of which Norrland and Dalecarlia contain 35,091,000 acres. Of these forests the State and other public authorities own about 17,520,000 acres, the management of which is under the care of the Swedish Forest Department. According to the estimate of the Forest Department, these 52,412,000 acres of woodland are now producing annually about $1,219,426,000$ cubic feet of wood. This is only a growth of somewhat over 23 cubic feet per acre per annum, an eloquent testimony not only to the present condition of the woods, but of their future potentiality. These Swedish woods consist nearly exclusively of Scots pine and spruce, with a sprinkling of birch and alder, and it is the two former descriptions, which supply a large portion of the softwoods consumed in the United Kingdom, to which these remarlis principally apply. In this connection it is instructive to find that, while the $11,500,000$ acres of State forest in Germany bring in a nett annual revenue of about 8s. an acre to the State, the Swedish State forests only produce a nett profit of about $6 \mathrm{~d}$. an acre! It should, of course, be mentioned that the bulk of the Swedish State forests are situated in the extreme north of the country, near to the 
Arctic Circle, where the growth is very slow, and where the means of getting the produce to market are yet comparatively undeveloped. Leaving out the State forests altogether, and confining ourselves to the better-managed forest properties of the large Swedish saw-mill companies, it is few of them that yet show an annual profit of more than 3s. an acre. That this is capable of considerable increase, when regard is had to the fine waterways of the country, goes without saying. One important factor for achieving this increase of profit is now being found in the development of the wood-pulp trade, whereby a remunerative market is found at home for the small spruce wood. Hitherto the only market of any appreciable magnitude for this immature wood, or thimnings as they are called, has been either in the form of pit props or small square balks for Egypt or North Germany, for which the prices obtained in situ have been so low that nothing was left for the wood after the expense of getting it to the seaboard had been deducted, unless it grew in the immediate neighbourhood of the waterways or railway.

'It has been urged that a large portion of the props and pit wood used in the mines of the United Kingdom ought to be, and could be, advantageously produced at home. At present prices it is probable that this can only be done where the cost of transport to the collieries is low. For wood of this description the cost of transport plays the greatest rîle, and efforts will have to be directed towards getting the very high rate of carriage on British railways reduced. As compared with German and Swerlish State lines, the cost of carrying pit wood and props in the United Kingdom is very high-in many cases double-for distances of one hundred miles and over. Of course, the comparison between the cost of transport on the Swedish waterways and British railways is still more unfavourable to the latter, and this fact will 
have to be neutralised somehow or other before the growing of props and pit wood in the United Kingdom can be made a commercial success.

'These remarks, let us say at once, are not made for the purpose of throwing cold water on reafforestation schemes, but merely with the object of pointing out the difficulties in the way, so that failures may, if possible, be avoided. To judge by the attitude of the authorities in both Scandinavia and Finland, it is not likely the present unrestricted export of small raw wood for props will be allowed to continue for long without the imposition of a heavy duty. The wood-pulp factories of Sweden will probably require all the small spruce (or whitewood, as it is called in the trade) at home, and then means will be found to hinder its shipment. When that time arrives the price of props and similar wood will rise considerably, bringing the question of growing part of our requirements at home within the boundary of a paying proposition. As far as the supply of building wood from Sweden is concerned, it is to be apprehended, as previously remarked, that it will have to be reduced for some years; but this is far from a famine, and there is reason to believe that the Swedish forests in twenty to thirty years' time will have regained some of the productive power, which part of them have undoubtedly lost for a time. It must be borne in mind that the State and other public forests represent one-third of the whole area of woodland, and these are certainly not being overent, but rather the contrary. Further, a considerable proportion of the remaining two-thirds is now held by the large wealthy saw-1nill companies, who must in self-preservation manage their woods so as to ensure a permanent supply of the raw material, otherwise the large sums spent on saw and planing mills and on the clearing of the rivers, etc., for floating will have to be written off. What the exact area 
of woodland held by the saw-mill companies amounts to is not known, but it is probably more than $8,000,000$ acres, and this of the best and the most favourably situated woods; so that, adding this area to that under the ægis of the Swedish Forest Department, fully 60 per cent. of the woodlands are in safe hands, that are bound to manage them properly in future. During the last fifteen years the Swedish Forest Department has consistently pursued the policy of adding to its forest property, more especially of denuded or partially denuded areas that can be worked in connection with its other forests, and it is understood this policy is to be continued.

'Various measures have also been passed by the Swedish Riksdag with the object of conserving the forests during the last decade, the most important of which is the Replanting Law, which came into operation about four years ago. By this enactment local committees are appointed for each county, whose duty it is to watch over the felling of the forests, and under the supervision of the forest officer appointed for that purpose, to ensure that replanting takes place. Both the owner of the ground and the lessee (if the wood has been leased) are held jointly liable in case the land is handled in such a manner as to hinder or delay reproduction.

'The so-called Norrbotten Law, which prohibits the cutting down of any Scots pine or spruce tree in the counties of Norrbotten and Westerbotten for export that is under 9 inches in diameter 16 English feet from the root, has been operative for many years, while this enactment has been further strengthened by the formation of protective zones in the mountainous districts between Sweden and Norway, within which all cutting of timber is prohibited except with the sanction of the forest officer appointed to supervise the carrying out of this Act. In these storm-swept districts, where the climate is very 
severe, it has been found that the denudation of the ground is apt to push back the cultivated zone and render considerable tracts uninhabitable.

'The greatest danger to which that portion of the Swedish forest still held by the landowning peasantry of the country (probably amounting to over $15,000,00$ () acres) is at present exposed arises from too frequent thinning. The ground gets too much exposed thereby, and gradually loses its humus covering. The small spruce trees then frequently wither, and, where this does not take place, are uprooted by high winds, especially when the trees are laden with snow.

"To show how experts on afforestation differ as to the condition and capabilities of the Swedish forests at different periods, it is interesting to compare the report of a Royal Commission in 1870 on the forests of the province of Norrland with that of the Forest Department last year. The former reported that, "When the Norrland forests were brought into the fullest reproductive growth of which they were capable, they would produce annually $174,414,570$ cubic feet of $\operatorname{logs} 10$ inches in diameter and upwards, and 283,797,885 cubic feet of smaller wood, or $458,212,458$ cubic feet altogether for export, in addition to local requirements; and that, taking the year 1868 as a basis, a very considerable overcutting was then taking place." On the other hand, the Swedish Forest Department reported last year that the total annual growth of the whole of the Swedish forests was estimated at about 1,218,909,000 cubic feet altogether, of which about $176,500,000$ cubic feet cannot be utilised under present arrangements, but must be left to rot in the woods! Further, it is estimated that there is an overcutting at present of about $1,500,000$ cubic feet annually from the forests that are now accessible. That is to say, if a tithe of the wood that is wasted could be brought to 
market there would be no overproduction at present: If there was a heavy overproduction in 1868, as the Commission then reported, when the wood shipped from the country was less than half its present volume, there must be a ruinous overproduction now. The Forest Department, however, by the light of its long knowledge of the woods, says there is only a very small and partial overproduction. For the purpose of better utilising some of the logs from the State forests in the north of Norrland, and hindering the waste of small wood which takes place in these woods, a committee is now examining into the feasibility of building a large saw-mill and wood-pulp factory by the Forest Department. This would, of course, not be done were the Department satisfied with the prices realised for their raw wood.

' In this connection the Russian Forest Department was confronted more than ten years ago with the same difficulty that the Swedes are now trying to solve-namely, the inadequate prices obtained for raw wood. This led the Imperial Domains Department in Russia to erect sawmills in 1897 and work part of their woods themselves, which they have continued to do ever since. It may here be pointed out that the Russian State forests and those of the Imperial Domains cover an area of no less than 250,000 square miles in the provinces of Archangel, Vologda, and Olonetz alone (practically the whole of these immense provinces) in addition to the State forests that have their outlet at St. Petersburg and the Baltic ports. Of the total Russian export of wood goods, about 50 per cent. comes, in fact, from State forests, and we are told the present shipment could be increased largely without injuring the productive power of the woods. The British Consul-General at Petersburg lately reported that "The difficulty, however, does not present itself as to where and how to 
obtain the material, but rather as to how to dispose of it, at a profit."

'Now, although British Consuls can certainly not be implicitly followed as guides in forestry economy, there is no reason to doubt the correctness of this report, although a well-known authority in Scotland will certainly not allow it to pass without remark if he gets a sight of it. There is no doubt there are ample supplies of soft building woods in Russia, and that of prime quality, but the difficulty is to get them to market on competing terms. Notwithstanding the sparse population and the severity of the climate in winter, together with the plague of mosquitoes in summer, some progress is being made in the north of Russia, which has already taken the place Sweden held during the last quarter of the nineteenth century as the principal purveyor of building timber for Western Europe.

' One very important factor towards making afforestation in the United Kingdom a financial success will have been found when Scots fir can be used for the manufacture of wood-pulp equally as well as spruce. The redwood (Pinus sylvestris) of Sweden is now being largely used for the making of sulphate cellulose at many Swedish works, and we presume Scots fir at home will not be more refractory. We are convinced that herein lies the road, or one of the roads, to financial success, as far as the production of Scots fir and spruce is concerned. The wood-pulp works will, of course, be located as near the woods as possible, whereby the cost of transport will be greatly reduced.

"Next to the question of transport, it is essential that afforestation be undertaken on sufficiently large and compact areas so as to bring the cost of supervision after planting to the lowest possible amount. Close planting should be adopted-closer than usual in the Uniterl 
Kingdom ${ }^{1}$-and wherever the nature of the ground and the situation of the wood will permit, care will have to be exercised to choose a variety of tree that is in demand in the neighbourhood, at the same time that its probable realisable value will be as little affected as possible by cheap foreign supplies. The larch, for instance, in many parts of the United Kingdom meets these conditions. Except from the White Sea Basin, no important supplies of this wood can be obtained from abroad, and even from the northern provinces of Russia, where it can be obtained in quantity, the cost of bringing it to market is prohibitory at present, and will be for many years. Larch does not grow in the Scandinavian Peninsula or in Finland to any appreciable extent, and its quality is inferior where it has been planted there.

' There are also amongst hardwoods some that can be grown with advantage in the United Kingdom, where the supplies from abroad are bound to become less and less. Ash, for instance, in the United States, according to the testimony of the largest agricultural implement makers in that country, can hardly be obtained in sufficient quantity for local consumption, and there are other woods in a similar position.

'The conclusions, therefore, to which we have come are that, while we do not believe a timber famine is so imminent as some alarmists would have us believe, we consider the position such as to justify the intervention of the government. To make re-afforestation a success, a fresh Forest Department will have to be created, to which all the State woodlands now existing should be transferred, and with powers to gradually add to these suitable areas with especial reference to the question of transport. If these areas are sufficiently large and compact so as to be economically worked, and the administration put in the hands of the most experienced persons obtainable, no

1 This opinion is not shared by the author. Vide chap. vi. 
doubt these woodlands will become a most valuable public asset, at the same time creating a large field of employment and means of subsistence on now almost valueless areas. The proposed department will, however, have to be managed with the most rigid econony if it is to become even a qualified commercial success; and the usual British habit of staffing the higher grades expensively and starving the lower will have to be discarded. At the outset the idea of utilising any large number of the unemployed in preparing the ground will not be feasible. The most experienced and efficient labour available will have to be used, otherwise the cost will be prohibitory.

'Since the above was written, the writer has had the opportunity of perusing the extract from the report of the Royal Commission on this subject, and must say that the financial proposals appear to be in the highest degree unsound as far as they refer to the production of coniferous timber.

' The Commission proposes to plant or replant 150,000 acres annually, at an approximate cost of $£ 2,000,000$. No data have been given apparently as to the average distance of these 150,000 acres from the place of consumption, and the whole question of the cost of transport appears to have been treated very summarily, although it is vital to the financial success of the scheme. Let us, however, compare the cost of these replanted 150,000 acres with the present value of a similar area in Sweden, situated within five or six English miles of cleared and amortised waterways, where the cost of getting the raw material to the coast is less than the cost of fifty miles railway carriage in the United Kingdom. In the Lower Gulf districts of Sweden, answering to the above description, the cost of a newly planted area of redwood (Pinus sylvestris) or whitewood (Picece excelsu) will be less than $£ 2,10$ s. an English acre, whereas the cost of this replanted 
British land will be about $£ 13,6 \mathrm{~s} .8 \mathrm{~d}$. ! Let us give another example. There is at present a forest estate for sale in the Lower Gulf district of Sweden, situated within almost a ring fence, about twenty-five English miles from a good harbour on the Culf of Bothnia, and with a line of railway almost running through the estate, at a price of $£ 2,5 \mathrm{~s} .9$ d. per English acre. This estate contains about 11,000 acres, well covered with red and white wood (mostly red) of first-rate quality, where the average age of the trees is probably over twenty-five years, with a sprinkling of sawable logs. The cost of carrying the produce of this property to the harbour on the Gulf of Bothnia by rail is about $1 \mathrm{~s} .6 \mathrm{~d}$. per ton, the cost of putting the goods from the railway truck on board ship is about 4s. 6d. per Petersburg standard hundred, and the cost of freight to London is not more at present than 21s. per Petersburg standard hundred. If your readers compare the proposal of the Royal Commission financially with current values in any European wood-exporting country they cannot but see its absurdity as far as coniferous wood is concerned, and there is at least one gentleman who gave evidence before this Commission who would decidedly not give $\$ 500,000$ for what the Commission propose to spend $£ 2,000,000$ on! As a matter of fact, there is scarcely one firm in Sweden that would not sell its whole forest property for less than $£ 2,000,000$, and half a dozen of the Swedish companies own a good deal more than 500,000 acres of woods in full bearing condition, with an average growth of over fifty years.'

In connection with the total area of woodland needed for any country, the question of ownership becomes an important one. At the present time, the various States of Europe own about 50 per cent. of the total forest area, while communes, corporate and ecclesiastical bodies, etc., own about 16 per cent. At a rough estimate, there- 
fore, two-thirds of the forest area of Europe are owned by public bodies which have no direct incentive, on pecuniary grounds, for destroying their property, but are more likely to improve it. If Britain is to follow on the same lines as are found necessary or expedient elsewhere, this point must be carefully considered. Apart from Russia, in which the State owns 60 per cent., and communes 10 per cent., or an area of about $320,000,000$ acres between the two, the proportion of state, communal, and corporate forests in other European countries is much lower than is stated above, being less than half the total area, leaving private ownership the predominating form in which woodland is held. As is well known, this form of ownership prevails over 95 per cent. of the existing woodlands in Great Britain and Ireland, and applies equally to planted and unplanted land. Except on entailed estates, on which some obligations as to replanting or maintenance of existing woodlands are observed in a perfunctory manner, British woodland proprietors are at liberty to dispose of this form of property as they choose, and may allow the timber to decay on the ground, destroy growing crops by improvident thinnings or premature fellings, or divert the land entirely from timber-growing and put it to other uses. Such freedorn as regards private woodland is not universal over Europe, and in most countries legislation compels the private owner to maintain and renew his woods for all time, unless special reasons exist for the employment of the land otherwise. This is, in a general way, as it should be, for crops which require care and expenditure during three generations to produce should not be destroyed by the indifference or selfishness of a fourth.

In countries in which compulsory upkeep is enforced, it is generally recognised that some form of assistance from the State is necessary to bring about the desired results. While the returns from properly managed woods 
are usually sufficient to more than provide for their economical maintenance, long continued neglect, or excessive fellings by a previous generation, may entail a hearier expenditure in improvement and restocking than should be legitimately borne by one individual, and in recognition of the possibility of this being the case, assistance is often given in the form of loans at a low rate of interest, the sale of cheap trees, suspension or reduction of rates and taxes on young woods, subsidies for planting bare land, and technical advice and assistance in all matters connected with forest management. Under such conditions there is then a double inducement given to the private wood-owner to maintain his woods, and forest destruction is adequately guarded against.

In Great Britain the only form of assistance rendered to the private owner by the State is a limited amount of advice at a cheap rate, and loans at a comparatively high rate of interest. In Ireland, an adrlitional advantage is offered to planters in a small way, by an arrangement made by County Councils for supplying trees at wholesale prices. Apart from these feeble forms of assistance, it may be said that the private wood-owner is entirely left to his own devices, and that three-fourths of the entire woods in the country could, for all the law of the land could say to the contrary, be swept off the face of Great Britain as fast as timber merchants could buy and fell them.

The general effect of this absence of State control over private woods has been that the British Isles are gradually decreasing their economic forest areas, while the depreciation in their value through excessive thinnings and premature clearings during the last twenty or thirty years cannot be less than an enormous sum. This decrease in area and value is due to various causes, but is probably chiefly attributable to the financial difficulties which have surrounderl the upkeep of large agricultural 
estates during that period; amongst which the falling of agricultural rents, the imposition of Death Duties, and, in Ireland, the effect of various Land Acts, may be mentioned. In England and Wales it is true a slight increase may be noticed in many districts in recent years, the actual area under woods being officially returned as higher in 1905 than in 1895 by over 50,000 acres. This increase is chiefly due to planting for game cover and ornament on moderatesized estates owned by wealthy manufacturing men, mineowners, and others who do not derive their entire income from the rents or development of agricultural land.

Unless a decided change in the conditions of private estates takes place, therefore, it is evident that a decrease rather than an increase in the area of privately owned woodland is likely to occur. The general tendency at present exhibited by landowners in restricting outlay to purely personal objects, such as are likely to give a quick return, or an easily realised increase in the capital value of their properties, is altogether opposed to the principle involved in tree-planting for timber production, viz., the sacrifice of all life interests in the yield from the land planted, together with an investment of capital which cannot be recovered under a period of fifty to one hundred years. Either special inducements must be held out, or compulsion applied to the private owner to maintain his woods in an economic condition, and increase the area under timber, or the State must acquire the woods in danger of destruction, and the necessary land adapted for aftorestation, if an area approaching 7,000,000 acres of woods is to be brought into existence in the British Isles. The measures which might be taken to bring about the desired results in these directions must be dealt with in a later chapter.

The national aspect of forests in connection with climate, storage of rainfall, prevention of soil erosion 
fixation of sand-dunes, shelter from wind and sun, landscape adornment, etc., is of considerable importance, but is less easily expressed in exact terms than the supply of, and demand for commercial timber. In the tropics, climate may probably be modified as regards temperature and rainfall by forest growth, while the effect of a large area of woodland upon water storage is self-evident. Soil erosion on steep slopes, or the shifting of drift sand, can be prevented by the binding action of tree roots, while their stems and branches obstruct both the formation of water chamnels, and the passage of wind currents on or over the surface. The effect of trees as wind-breaks, and the creation of shaded air spaces and soil surfaces, have a distinct and easily noticed influence upon local climate, and the :esthetic effect of clumps, belts, and single trees upon a landscape is recognised by all communities possessing the most elementary ideas on civilisation and natural beauty.

While the consideration of the above facts might be extencled to several chapters, it is sufficient to deal briefly with those which more closely affect the British Isles in their physical, hygienic, or social bearings. The theory that the climate of these Islands generally has been, or can be affected by forests is gradually being destroyed, athough observations have not, perhaps, been carried sufficiently far to prove this conclusively. The storage of rainfall is not entirely dependent upon forest growth, and the uniform distribution of rain throughout the year renders it less necessary than in countries with definite periods of alternating drought and excessive rainfall. This uniformity also decreases the general tendency of heavy rain to wash the finer soil particles into water channels and rivers after prolonged drought, and a further deterrent to this process is provided by the almost continuous growth of grass, moss, etc., throughont the year, 
leading to the formation of turf and peat moss upon all but the hardest rock surfaces, thus providing a binding and water-storing surface for even the steepest slopes. The low elevations, grass or heather covered surfaces, and the gentle slopes of hill ranges in the British Isles also prevent soil erosion becoming a serious factor in the natural economy of the country, although it goes on to a limited extent in all districts with heavy rainfalls.

While tree growth may be of comparatively little importance in connection with the above matters, it is otherwise when the question of wind-breaks and ornamental timber is concerned. It is true that our strongest and prevailing winds are fairly warm, and that the cold, drying winds which so seriously check vegetation in some parts of Europe, such as the Russian steppes, are limited in duration, and moderated in intensity. Shelter from hot sun, again, is not a pressing need in many parts of the British Isles, and may only be needed for a few days in the year. Landscape effect,may be regarded by some utilitarians as a matter of little importance, and one which might well be left to those with time, money, and opportunities for attending to it on their own properties. But after making due allowance for the above facts and possibilities, observations in districts practically bare of shelter trees and ornamental timber will convince one that something is wrong in their economic and social conditions, and that poverty and ignorance have much to do with a lack of one of the most attractive physical fentures of a country. Districts with the poorest soils, the worst climates, and a population hardly able to exist by the most primitive methods of livelihood, are invariably the poorest in tree growth and shelter plantations. Many parts of Scotland, the north of England, Wales, and Ireland, may almost be recognised, outside manufacturing or mining districts, as prosperous, or the reverse, by the 
presence or absence of trees. Exactly why this should be is difficult to say in all cases, but in most it can clearly be traced to a custom, born of necessity and a low type of civilisation, of living on and amidst the barest necessaries of life. Prosperity and refinement, on the other hand, always bring about a system of preserving and creating tree growth on a scale commensurate with the development of the country, and the requirements of its particular situation.

Trees grown for ornament and shelter must be regarded as factors which ameliorate and improve the climatic, hygienic, and social conditions of any district, and as such they will be provided wherever the population possesses sufficient intelligence and wealth to recognise these facts in the first place, and means to act upon them in the second. Under the influence of shelter trees, the local conditions under which mankind exists are improved by a higher or more uniform temperature, more luxuriant vegetation, and more healthy surroundings for live-stock than where trees are absent. Landscape or ornamental trees, again, render a district less monotonous, more attractive, and present a greater variety of outlooks to the eye than is possible in treeless localities. It is said that an absence of all interests or changes in life leads to intellectual deterioration, and frequently to insanity. If this is so, a monotonous landscape must aid in the same direction, and there is every reason to suppose that the amenities of life are as necessary to the healthy development of a civilised community as food and warmth. It is perhaps impossible to state the proportionate number of trees or acres of shelter wood which are necessary to constitute a properly balanced country. There are innumerable gradations between the man who plants a tree in his back garden or front lawn to the planter or owner of a wood of fifty acres, and street and hedgerow trees play as import- 
ant a part in their way as the larger belts and clumps which occupy several acres of land. As regards area, however, there is no reason to suppose that this need be large, and even 1 per cent. of land devoted to such a purpose should provide all that is necessary, and an owner of one hundred acres of land should have little difficulty in keeping one of them under trees.

In this work, as in the larger one of economic forestry, the British Isles are far behind other countries in the matter of State assistance and control. Planting for shelter and ornament must be done in a general way by the private individual on his own land, but street and roadside trees could, and possibly would, be maintained by local authorities if assisted by Imperial funds. In such countries as Denmark, Holland, etc., in which this form of planting is especially desirable, State-aided organisations are at work with the object of assisting and encouraging both local bodies and private owners; and extraordinary progress has been made in what at first looked like a hopeless undertaking. This work will, however, be dealt with in a later chapter. 


\section{CHAP'TER III}

THE RELATION OF AGRICULTURE TO FORESTRY

DEVEI,OPMENT

THE geographical position and physical features of the British Isles are very largely responsible for the manner in which the land of the country was utilised by Nature in the past. As already pointed out in a preceding chapter, forests were the dominating forms of plant growth throughout Europe, and from end to end of the British Isles elevation and poverty of soil alone placed any considerable limit to their extension and reproduction. In many instances, however, the increase in population, and the creation and development of industries have been exerting an influence upon land utilisation which has gradually altered the face of the country to that which it now presents. The earliest industry associated with mankind may be said to be agriculture, for upon it food, and to a great extent clothing, depended as civilisation advanced, and the neerls of the population exceeded the supplies furnisherl by grame and fish, or diminutive flocks and herds of half-wild sheep and cattle. Any reference to land utilisation, therefore, must take into account the population which exists in direct or indirect connection with it, and it is necessary to ascertain the alsolute or comparative density of population in different parts of the British Isles before its effect upon actual or potential afforestation can be estimated.

It is only within comparatively recent times that the population of England and Wales can be traced, and the 
earlier records are necessarily of a more or less uncertain nature. Hallam supposes that the population in the eleventh century, as recorded in Jomesday, was about 1,000,000 hear; while it did not exceed 2,300,000 in 1377, and remained more or less stationary, according to Thorold Rogers, for the three and a half centuries following. The latter authority estimates the possible cultivated area in the thirteenth century at 3,000,000 acres. Down to the seventeenth century, therefore, both population and the area of cultivated land must have been small enough to have allowed ample space for the existence of natural woods and forests, and history generally supports this assumption, although from the complaints of Evelyn and his contemporaries, the stock of timber in them appears to have dwindled very low by that time. Perhaps the point of most importance in this connection, however, is the fact that until the eighteenth century not more than twothirds of England and Wales were enclosed, and immense areas still remained in the shape of commons and manorial wastes. These commons and wastes may be clearly regarded as the unimproved remains of natural forests, more or less denuded of their timber by continuous grazing, and the exercise of timber and fuel rights. They were, strictly considered, therefore, the analogues of the state and communal forests of the greater part of Europe, the chief difference being that while in the latter the value of the timber was recognised, and its preservation assured by forest laws and ordinances, the importance of the timber crop in Britain was gradually lost sight of as the agricultural value of the land increased, on account of the rise in population and the value of agricultural produce. In this one-sided appreciation of common land the increasing use of coal for fuel had possibly something to do, firewood being no longer needed in manufacturing districts and towns as transit facilities improved. 
How great an opportunity for successful afforestation has been lost within the last two centuries may be gauged from the fact that nearly $10,000,000$ acres of common land were enclosed by Acts of Parliament between 1750 and 1850 , practically resulting in the appropriation, for agricultural purposes, of all land available for first-class timber production on a large scale. Some, no doubt, of this land was planted by the larger landowners or lords of the manors, who received the greater portion of the enclosed lands; but the present area of woodland in England and Wales shows how inadequate this was compared with the needs of the country. The fact that the unenclosed land still in existence consist, entirely of the poorest and most elevated portions of the country also proves that the process of enclosure only stopped short at land which was not worth enclosing, and explains why large and undivided areas cannot now be found, except on mountains and heaths of the poorest description, and more or less unsuitable for any form of improvement. In the reigns of George II. and George III. a few measures were passed for the enclosure of wastes, expressly for timber-growing purposes, but nothing appears to have come of them, and with the exception of some half-dozen Crown forests which have escaped transference or sale to private individuals, State forestry in Britain can scarcely be said to exist, while facilities for its creation on modern lines have also been lost to a great extent.

The general result of the wholesale appropriation of fertile and favourably situated land for agricultural purposes in Britain has been of the greatest detriment to British forestry, and seriously impedes any rapid progress being made in the work of afforestation. On the Continent, land similarly situated, and of equal fertility to that so extensively enclosed within the last century or two in Britain, has been occupied by forests from early 
times, and possesses a very similar history to that of the English commons until the last two or three centuries. The absence of a forest policy, or any measures for the preservation of the natural timber in Britain constituted the only important difference between them, and, doubtless, led to the tinal absorption of commons and forests by the cultivated and enclosed areas adjoining or surrounding them. This fact has to be constantly faced by advocates of State afforestation on economic lines, and any unbiassed comparison between the State forestry of France, Germany, etc., so far as its financial aspects are concerned, and the possibilities of a similar system being built up in Britain invariably brings out this point as a difficulty of considerable magnitude.

Closely associated with the conversion of open or common land into enclosed farms and holdings has been the rapid rise in population during the nineteenth century. In 1801 the population of England, Wales, and Scotland did not much exceed $10,000,000$, of which nearly $9,000,000$ were in England and Wales. With an area in the latter countries of about $37,000,000$ acres, this represented an average density of 160 head per square mile. In Scotland a population of $1,608,000$ on $19,000,000$ acres represented 54 head per square milo. In 1901 the population had more than quadrupled itself in England and Wales, and increased by $1,250,000$ in Scotland, giving a population in the former of nearly 1 person to the acre, and about 100 to the square mile in the latter. Apart from the commercial development of agriculture during the century, therefore, the increase in population would alone necessitate the utilisation of all available land capable of cultiva. tion or the raising of live-stock.

The present division of the land in Great Britain is, according to the Agricultural Statistics for 1900, as follows:- 


\begin{tabular}{|c|c|c|c|c|}
\hline \multirow{4}{*}{$\begin{array}{l}\text { England, } \\
\text { Wales, } \\
\text { Scotland, }\end{array}$} & $\begin{array}{l}\text { Crops or } \\
\text { Grass. }\end{array}$ & Woods. & $\begin{array}{c}\text { Grazed } \\
\text { Mountain. }\end{array}$ & Unclassified. \\
\hline & $\begin{array}{c}\text { Acres. } \\
24,600,000 \\
2,7 ! 3,61100 \\
4,873,000\end{array}$ & $\begin{array}{l}\text { Acres. } \\
1,715,000 \\
184,1000 \\
868,000\end{array}$ & $\begin{array}{c}\text { Acres. } \\
2,370,000 \\
1,288,000 \\
9,(1889,000\end{array}$ & $\begin{array}{c}\text { Acres. } \\
3,695,000 \\
483,00(1) \\
4,873,000\end{array}$ \\
\hline & $32,266,000$ & $2,767,000$ & $12,747,000$ & $9,051,000$ \\
\hline & $(=57 \%)$ & $(=5 \%)$ & $(=23 \%)$ & $(=18 \%)$ \\
\hline
\end{tabular}

The unclassified area consists partly of land occupied by towns, roads, buildings, small areas of waste, garden-land, etc. But in Scotland fully one-half of it exists in the form of deer forests and absolutely barren land, 25 per cent. of the total area coming under that head, while nearly 50 per cent. consists of mountain and heath used for grazing, leaving little more than one-fourth under cultivation.

In considering the above area in connection with afforestation as a national industry, several important questions present themselves, the chief amongst them being: (1) The comparative values of agriculture and forestry as national industries; and (2) The possibility, from a political and economic standpoint, of forestry being extended on land not needed for agriculture, or in the event of such land not being forthcoming, at the expense of it.

The first of these questions is an extremely difficult one to answer, but an attempt has already been made in Chapter II. to demonstrate the importance of a supply of first-class timber being maintained, together with the probable fact that this supply, in the shape of round timber, can only be forthcoming in the future from British soil. It is equally obvious that the production of corn, beef, and mutton is quite as essential for the sustenance of the nation, whether it be produced at 
home or abroad. It is a well-known fact that the area of cultivated land in the United Kingdom is insufficient to maintain the present population of over $40,000,000$ in corn and meat. The home supply of all classes of farm produce is said to possess a value of about $£ 150,000,000$, while the supply from the colonies and foreign countries amounts to $£ 120,000,000$. It is evident, therefore, that the home deficiency could not be made up by any possible increase in cultivation, for although tillage might be extended on land now under pasture, and an increased yield of corn and meat obtained, the nett increase could not make good a deficiency of some $10,000,000$ tons of produce. It would appear, therefore, that the requirements of the country in both timber and food are greater than the available area can supply on economic principles, and it becomes a question as to which class of produce can be most easily imported in the future at the lowest cost.

Timber, as already pointed out, is not a commodity likely to be artificially grown as a speculation on a largo scale by either public or private agency. Farm crops, on the other hand, are raised on an extensive scale by individual traders wherever the conditions aftord facilities for their cultivation, and prices are sufficiently high to repay the cost and labour involved. North and South America, Australia, and South Africa, not to mention India, Russia, etc, produce meat or corn in excess of their own requirements, while enormous areas of undeveloped land still remain for future cultivation. The probabilities are, therefore, that large timber will become a more costly commercial commodity than food in the future, apart from temporary disturbances of the world's markets. The two main reasons for arriving at this conclusion are that a timber industry cannot be built up quickly enough to meet suddenly arising demands or 
high prices, while the temporary pecuniary sacrifices, involved in the early stages of forestry development, prevent it ever becoming a private enterprise on a national scale. As raw material, timber must be regarded as quite as essential to the industrial progress of the British Isles as coal, iron, or cotton, and while food must obviously take the first place as a necessity of life, it may not be the most costly under normal trade conditions. Within reasonable limits, therefore, one may justify the contention that the agricultural area of a country should be limited or reduced for the purpose of maintaining an adequate forest area. This has, as a matter of fact, been done already in Germany, France, Belgium, and other countries possessing a rural population quite as dense as that of Great Britain, for wherever forest occupies land capable of cultivation, and is maintained on such land at the expense of the State, it is evident that the principle is recognised that timber is a necessity of industrial life to a greater or less extent.

The possibility of forest extension on land not used for agriculture in the British Isles may be practically regarded as out of the question. From the table already given, it is scen that all land in England and Wales not occupied by towns, roads, unavoidable wastes, etc., is accounted for, and the only class which might be regarded as unutilised is that described as mountain or heath land used for grazing. The large area in Scotland, both included in that class, and unaccounted for altogether, suggests the possibility of forest extension in that country to a greater extent than elsewhere, and it may be worth while to examine the coudition of this mountain area a little more closely.

From the above table, it is seen that the total area of grazed mountain in Great Britain is returned as over $12,000,000$ acres, three-fourths of which are in Scotland. Both of this class and the unreturned area, Scotland 
shows a very extensive tract of land of low and possibly no agricultural value. For many years various authorities have adrocated the planting of a large proportion of the mountain land in Great Britain, and rarious estimates have been formed of the approximate quantity suitable for the purpose. Witnesses before the Departmental Committee on British Forestry in 1903 stated their opinion that several millions of acres of waste land might be profitably planted. The Afforestation Report of the Royal Commission on Coast Erosion reported in 1909 that $9,000,000$ acres, chiefly mountain land, were probably plantable in the United Kingdom, of which 2,500,000 acres were in England and Wales, 6,000,000 acres in Scotland, and 500,000 in Ireland. The most moderate estimate made up to the present by any individual appears to be that of Dr. Nisbet, to the effect that one-fifth of the waste land of the country might be profitably afforested.

With the exception of that made by the Coast Erosion Commission, which calculated that 15 to 20 pounds of mutton per acre might be lost to the nation by the afforestation of this land, none of the above estimates has been made on an agricultural basis-that is to say, the value of the land for grazing purposes has not been seriously taken into account, beyond its mere rental value to the landlord. In mountain districts, howerer, it would appear desirable that a closer inquiry should be made as to the national value of mountain land as a necessary feature of stock-raising, and as a means of increasing the food supply and agricultural resources of the country. With this idea in view the figures in the table on page 68 may be of interest. From these it is seen that in England, where the total area of crops and grass represents 76 per cent. of the entire surface, there is an average of 20 head of cattle and 60 head of sheep per 100 acres of crops and grass. The area of mountain land in England being 
but 7 per cent. of the whole surface, it may be taken as an approximate fact that these figures approach the maximum capacity of the agricultural land for carrying stock. Yet in Scotland, with only 25 per cent. of the entire surface under cultivation, it is found that the number of cattle is slightly, and the number of sheep enormously exceeded, being between the two more than double that of England per 100 acres of cultivated land. While the methods of rearing, feeding, and wintering live-stock in the two countries, as well as the ages of the stock, may affect the significance of these figures to some extent, they clearly imply that the deficiency in the area of crops and grass in Scotland is largely made good by the mountain-grazing.

Confining the inquiries to counties, it is seen that the head of stock in the four counties of Sutherland, Peebles, Selkirk, and Inverness is greatly in excess of the maximum carrying capacity of the cultivated land, and varies from 380 to 657 per 100 acres of the latter. If the normal stock-carrying capacity of land having 70 per cent. of its cultirated surface under crops, and 30 per cent. under permanent pasture be put at 10 cattle and 90 sheep per 100 acres - the percentage corresponding to what is actually the case in Scotland, and the head of stock to what would probably be found in a mountainous district - the absolute necessity for the retention of a large area of mountain land for grazing, or a more or less total change in the system of farming, is self-evident. As is well known, mountain-grazing is principally confined to the summer months, and during the period when the cultivated or enclosed land is producing corn, roots, or hay. Any considerable reduction of the mountain-grazing, therefore, inust result in a relative reduction of stock or area under crops, as the case may be. Two questions present themselves in connection with such a reluction: 
first, the effect of a withdrawal of, say, 1,000,000 arres of the better portion of the hill pasture from the farmer or grazier upon the agricultural or rural economy of the country; and, second, the comparative value to the nation of the normal yiclds of these million acres in meat and timber respectively.

As regards the rural economy of the country, it has been a fairly well-established fact for years that live-stock, in the form of cattle, constitute the most important and profitable proportion of the farmer's capital. Wheat, which at one time formed one, if not the most important, oljective of British agriculture, has declined both in acreage and price, while cattle have increased in numbers, if not in value, during the last thirty years. The following table, derived from the Agricultural Statistics of Great Britain, shows the changes which took place between 1877 and 1906 :-

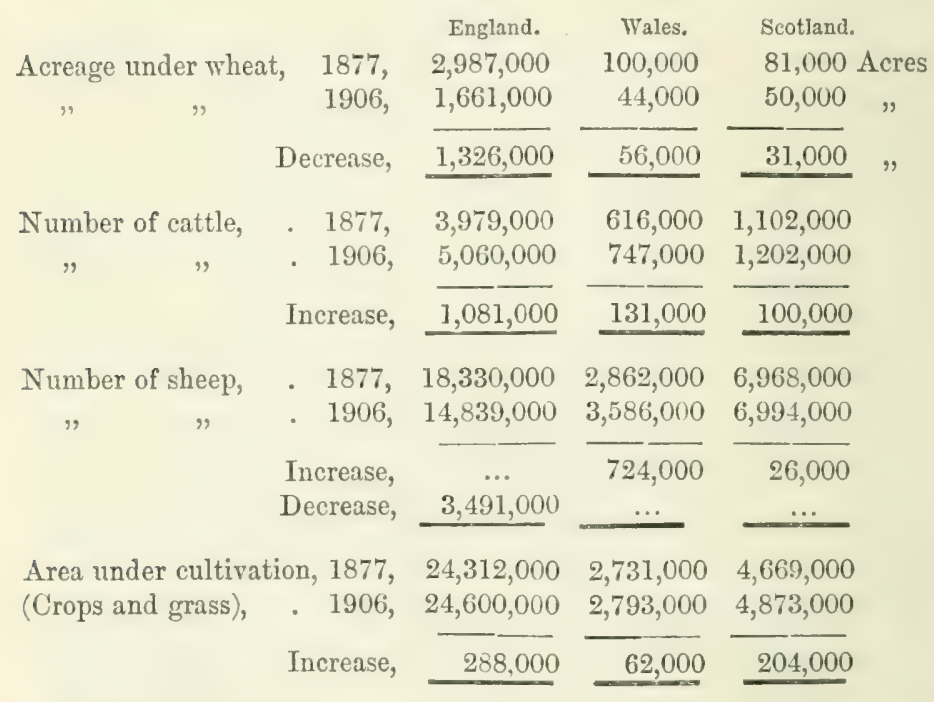

From the above figures it is evident that the decrease in wheat cultivation and the stock of sheep, and the in- 
crease in the rearing of cattle, are the chief changes in the principal productions of British agriculture. The increase in the area under cultivation, as represented by crops and grass, of over 500,000 acres in Great Britain, was accompanied by a decrease of nearly 3,000,000 acres in arable land, showing that wheat was not the only crop which decreased on that class of land, while permanent pasture greatly increased. The decrease in sheep was entirely confined to England, and probably connected with the decrease in arable land.

These various changes would indicate that land suited for the production of beef and milk is of relatively greater value and importance to the agriculture of England than that suited for sheep or wheat production alone, as the case may be. In Scotland, the changes throughout the period were comparatively small, although relatively the same with regard to wheat as in England, and showing the same tendency to increase in the head of cattle, the sheep stock remaining practically the same. These and other well-known facts which cannot be gathered from statistics, lead to the conclusion that land capable of producing good grazing is of the greatest importance in the development of modern agriculture; while land unsuited for grazing cattle on account of its rough or broken surface, or which produces such poor pasture that cattle will only thrive and fatten with the assistance of artificial feeding in summer, is of least significance to the grazier. In a general way, it may almost be said that the whole of the agricultural value of the British Isles at the present time is determined by its beef and milk producing capacity. The highest rents are paid for soils rich in these elements which maintain the fertility of land when under permanent pasture, the lowest for those which exhibit a tendency to become unfertile unless repeatedly manured or broken up by the plough. With the former, 
the maximum of profit is obtained with the minimum of labour; with the latter, profit is chiefly dependent upon the labour and energy employed to produce it. While clayey or loamy soils, alluvial tracts, water-meadows, etc., are highly valued and eagerly sought after, the demand for sandy or gravelly soils, deficient in lime, potash, and phosphates, is rarely greater than the supply, unless they possess certain advantages of situation, or can be obtained at a low rent. Near towns or industrial centres comparatively poor land can be turnéd to account, partly owing to the abundance of manure in the shape of city refuse, partly due to the higher value of agricultural produce. In remote districts a large acrenge obtained at a low rent per acre enables the individual farmer to obtain a profit sufficient to maintain himself in comfort, although the return per acre may be very low, and the produce of little value to the community in the form of national wealth.

Considered from the above point of view, a large proportion of the British area must be regarded as of comparatively low agricultural value, included in which would be the mountain and heath land already referred to. Of the total area of land used for agriculture in Great Britain, amounting to 45,000,000 acres, at least onethird may be estimated as possessing a rental value varying from $1 \mathrm{~s}$, to $10 \mathrm{~s}$. per acre, or $5 \mathrm{~s}$. per acre on an average. Assuming that the rent is equal to one-fourth of the gross return, it would appear that some 15,000,000 acres are not producing more than $£ 1$ per acre under any form of utilisation, being about one-tenth of the total estimated value of agricultural produce grown in Great Britain. Without further examination, therefore, it is quite reasonable to suppose that this area might be devoted to timber-growing without serious inconvenience to the agricultural interest, or loss to the food supply of the 
country. Timber to the value of $10 \mathrm{~s}$. to $20 \mathrm{~s}$. per acre can be produced on lind of moderate fertility, and if the climatic and soil conditions on this inferior third of the agricultural area are up to the standard required to produce timber to the value named, it would simply be necessary for one industry to take the place of another for the purpose of enabling an adequate extension of the forest area of the country.

When the distribution of this inferior land is considered, however, together with its connection with the cultivation of the more fertile ground adjoining it, it is seen that difficulties exist in the way of a wholesale transfer of poor pasture from agriculture to forestry. If the poorer land formed a large and compact stretch, which could be separated from the more fertile parts of the country without any great change in the boundaries of existing farms, or systems of agriculture, and from which a given number of occupiers or owners could be bought out at the market value of their land, the change desired could be effected without serious difficulties other than those connected with finance. But a glance at the physical features of any mountainous country at once reveals the fact that poor land is everywhere intersected and split up by valleys and glens of good or comparatively good soil, carrying a population and head of stock greatly in excess of that found on an equal area of similar land in districts of a more fertile nature. From an abstract point of view this fact is of little consequence, as every acre sufficiently fertile, and supporting a sufficient number of persons or cattle, could be excluded from any scheme of afforestation. But in practice the transfer of land on such a purely economic basis is impossible. Commercial forestry requires large unbroken areas, not merely in one county or district, but comprised within a limited boundary line. Small detached patches, while possibly 
capable of producing good timber, cannot be afforested and maintained economically by the State, especially in a country in which fencing is an indispensable and heavy item of expenditure. To obtain large areas of a thousand or more acres in one block and of the exact type of land required for strictly economic forestry, is almost impossible in Great Britain. If chosen within the zone of fertile land the block will invariably contain some of the latter, while if selected well above the cultivable portion a certain proportion of barren land, too poor and exposed to grow timber profitably, must be included. There may, of course, be exceptions to this statement, but a careful examination of mountain land will confirm the accuracy of it in a general way.

One important result of this intermixture of good and bad soils is the necessity of some change taking place in the system of farming, or the planting of valuable land in districts in which large areas are bought for afforestation. Either the farmer must adapt himself to a more limited area of mountain land, and follow methods which prevail in lowland districts, or the purchase of plantable land will involve the inclusion of a certain proportion of rich pasture or arable in addition to the poorer quality usually associated with afforestation. In the latter case, forestry can be carried on under more favourable conditions, but the expenses of purchase are greatly increased, for the tenant or occupier must practically be bought out of his holding, and be paid, directly or indirectly, for disturbance. This process, however, can only proceed to a limited extent, and very gradually at the best. Any wholesale clearance of mountain farms would be resented on political, if not on economic grounds, unless negotiations were conducted on voluntary lines only. In some cases the occupier of a poor mountain farm would willingly give up possession on reasonable terms, but 
possibly his neighbour would not, and it is difficult, if not impossible, to fix compensation for compulsory disturbance in such cases. In Great Britain, no prairie or undeveloped land exists to provide the mover with a new holding, and it is only in times of agricultural depression that farms can be found without tenants for any length of time. Even where the transfer of land from agriculture to forestry is justified on economic grounds, the moral right of existence rested in an ancient industry must be recognised, and land which has been utilised for centuries for sheep-grazing cannot be turned into forest without the settling of many legal and industrial questions of greater or less importance to the various parties concerned. Rights-of-way, water, and other obligations imposed upon land in an ancient country have to be dealt with, and the most difficult business of all is probably the straightening and readjustment of boundaries, a necessary process if areas of convenient shape are to be obtained.

To take a concrete case as an illustration of what may be considered more or less typical of conditions prevailing in mountain districts suitable for afforestation, the following particulars regarding the small county of Selkirk may be given. As shown in the table on page 86, this county contains nearly 162,000 acres of agricultural land, of which 80 per cent. consists of mountain, and 20 per cent. of arable and enclosed pasture. 'This area is divided up into 236 holdings, each having an average of 124 acres of cropped, and 562 acres of mountain land. Each holding carries on an average, according to the figures for 1906, 15 head of cattle and 800 sheep, and Selkirk may, for all practical purposes, be considered a purely sheep-farming county.

The position of this county in the centre of the Southern Highlands of Scotland renders it less exposed to wind than the greater part of that country. Its geological formation provides well-drained soils generally 
favourable for timber production, and its industries are entirely supported or concerned with the grazing of sheep, and working up of woollen goods in its largest town, Galashiels. In 1891 this county is said to have had a murcl population of over 4000 , but which has since been reduced by about 500. Assuming that one-fifth of the rural population consists of agricultural workers, it would appear that 1 man finds employment on every 230 acres of total agricultural surface, or an average of 3 men to a holding. It might, therefore, be regarded as a county which could, from the size of its holdings and the use to which its surface is put, be partly acquired for afforestation without adversely affecting the interests of a large number of persons, or any important industry depending entirely upon the raw material, other than wool, produced within its boundaries.

Several features present themselves in connection with the afforestation of land in a county of this class, the most important of which are the gross values of the produce obtained from sheep-grazing and forestry respectively per acre of total surface, the cost of production in labour and materials, and the nett gain in money to the owner and occupier of the land. As regards the first of these, the gross value of the produce, it may be assumed that the 20 per cent. of arable land in the county is capable of producing more value and supporting more labour per acre under agriculture than forestry. The reasons for this are well known, and need not be further discussed. The relative economic importance of agriculture and forestry chiefly concerns the mountain land, the produce of which is mutton and wool in the one case and timber in the other. This land represents 80 per cent. of the total used for agriculture in the county, but a certain proportion of this, consisting of 
mountain-tops and land covered with peat, rock, etc., must be regarded as umproductive, although given in the Agricultural Returns as 'grazed,' while even a larger proportion is incapable of growing commercial timber. Onethird of the total mountain land may be safely estimated to belong to the former class, while another third is probably too poor and exposed to produce a paying crop of timber. Of the 130,000 acres of mountain land, therefore, 86,000 may be calculated as qualified to rank as grazing land of some utility, and possessing an average rental value of at least 2s. 6d. per acre, ranging from 5 s. per acre on the lower slopes to 1s. per acre or less on the verge of the barren portions. The gross return from agricultural land is roughly assumed to be four times the rent, and taking this to be approximately correct, a gross return of 10 s. per acre, amounting to $£ 43,000$, would be obtained from the grazed area. This would probably represent about 20 pounds of mutton per acre, or the increase in dead weight of a sheep during the season. The division of the amount named above between landlord, labourer, tradesman, rates and taxes, and farmer, is estimated as follows per acre:-

Landlord, or interest on capital value, . $2 \mathrm{~s}$.

Materials supplied in fencing, shepherding, etc., . . . . . $2 \mathrm{~s}$,

Labour-one man per 400 acres, . . . 2s. $6 \mathrm{~d}$.

Rates, taxes, etc., . . . . . 1s.

Farmer's profit = interest on working capital, 2s. $6 \mathrm{~d}$.

$10 \mathrm{~s}$.

The acquisition of the above area of 130,000 acres for afforestation might be expected to bring about the following changes in gross yield and distribution of expenditure, after a sufficient interval had elapsed to produce a normal return in timber. Of the whole area, one-third is 
estimated to be plantable with profit, and the yield from this, amounting to 43,000 acres, may be estimated at 50 cubic feet per acre per anmum, with an average value of $4 \mathrm{~d}$. per cubic foot, or $16 \mathrm{~s}$. per acre. This gives a gross return of $£ 3+, 000$, to which the possible grazing value of the unutilised third may have to be added in making up the total yield. As, however, this remainder must consist of the worst portion of the rentable land, and lie nore or less separated from the enclosed area by a fringe of woodland, its vilue can scarcely be more than 1s. 3d. per acre, or 5 s. gross return, equal to $£ 10,750$, making roughly a total of $£ 4 t, 000$ altogether. The distribution of the $16 \mathrm{~s}$. per acre would be somewhat as follows:-

Labour-one man per 120 acres,

$8 \mathrm{~s}$.

Materials-tools, housing, etc., . . . 2s.

Rates, taxes, etc., . . . . . 1s.

Interest on capital investment, . . . $5 \mathrm{~s}$.

$16 \mathrm{~s}$.

In the above estimate supervision is included in the labour bill, and the rate of interest represented by 5s. per acre would probably be about 1 per cent. on a capital investment of about $£ 25$ per acre. ${ }^{1}$ The chief differences resulting from the two methods of utilising the land are the higher gross yicld per acre, and greater expenses of labour in the case of afforestation. The nett yield per acre, in the form of profit to the owner and occupier, is less in the case of afforestation, but the benefit to the working community is very much greater than is the case with sheep-farwing, three times as much being spent in labour in growing the crop alone.

In actual practice, however, it is certain that the results would differ more or less from those assumed above.

1 See chap. viii. p. 234. 
It would be practically impossible to separate the mountain from the arable land so completely as to enable the one class to be entirely aftorested and the other to remain under agriculture. The straightening of boundaries, the preservation of rights-of-way, water, etc., and the general admixture of good and bad land prevailing in a countryside, compel the person or public authority anxious to obtain large compact areas to give and take in the matter of quality, price, and area of land acquired. But the averige results need not necessarily deviate greatly from those assumed. It may, of course, be contended that both the gross and nett yiclds from afforestation have been put far too low, and that the price per cubic foot, and possibly the volume per acre, should be more in agreement with returns given by many continental forests. But reasons will be given in a later chapter which will partly explain these points. As regards expenses, it is possible that labour has been estimated rather above the average of what is actually expended abroad, but there natural regeneration plays a certain part which tends to keep down expenditure in planting costs, and this process cannot be relied upon to the same extent in a hill district in Scotland lying at an average elevation of 800 or 900 feet above sea-level.

In practice, again, the temporary loss of rent and interest on capital during the interval between planting, and an adequate yield from the timber crop, has to be reckoned with. In the course of a century or so this loss might be made good and a higher yield obtained after the first rotation had been taken off the ground, but for the first fifty years or more no appreciable return need be looked for. 'l'his unproductive period is a serious drawback to forestry in practical economics, especially when money must be safely invested on good security, and it is a well-known fact that neither the large 
landowner nor the average investor is inclined to sink his capital in planting operations.

So far the idea of converting a pastoral district into a timber-growing area of similar dimensions to those found on the Continent has been discussed from an abstract point of view entirely, and from the financial and labour aspects of the case. An equally important side to consider, however, is the industrial and social change which would be involved in the process of reducing the size of farms, and in buying out holdings altogether. It may be taken for granted that the work of afforestation could only be undertaken by the State, and that the latter would have to purchase the land from the owner, and deal with the tenant or occupier afterwards. So far as the former is concerned, the question is largely one of price, but the occupying tenant possesses certain moral and legal rights to compensation for disturbance which cannot be ignored. Without going into the details of these rights, it may be assumed that purchase transactions would have to be conducted on a voluntary basis, or a price given above the market value of the land. In the former event, irregular boundaries and inconvenient areas must be expected, due to the unwillingness or reluctance of adjoining owners or occupiers to sell, for no two neighbours can be expected to regard a reduction of their holdings in the same light or with equal complacency. With compulsory powers of purchase, as recommended by the Coast Erosion Commission, compensation would increase the price of the land by at least 25 to 50 per cent. above its mere market value. A man previously occupying 500 to 1000 acres of land may not be willing or able to adapt himself easily to the occupation of about a fourth of that area, even supposing that the smaller area consisted of the best portion of the farm. In any case, his system of farming would have to be altered, and 
this would not be easily accomplished in a district which has been agriculturally developed under almost purely pastoral conditions. Labour supply, markets, and breeds of live-stock have to be found to suit the new conditions, and these changes require time, and, to be successful, must be made by the majority of the farmers in a particular district.

While no serious difficulties exist, possibly, in the gradual acquisition and afforestation of a considerable area of mountain land in a county or district previously occupied by large sheep farmers, it is erroneous to assume, as is often done, that the land can simply be taken over by paying a more or less nominal price for it. While a single farm here and there, or a few blocks of land, may be acquired on easy or reasonable terms without difficulty, the wholesale transfer of mountain-grazing from the farmer to the forester can only be accomplished gradually and cautiously, and with the consent and co-operation of the older industry already in existence. Where sinall holdings exist in the glens and valleys, the difficulties of transfer invariably increase, for the small farmer is probably more dependent upon the mountain-grazing for his subsistence than the wealthier man with a larger area of good land. To assert, as is often done, that millions of waste land can be profitably afforested is merely a confession of ignorance as to the real facts, for any land capable of growing timber is already yielding something to the stock-owner, and afforestation on a large scale means the reduction of the acreage under agriculture, or of the head of live-stock, as the case may be, although such a reduction may be to the national advantage.

To get land of any extent in this country means, to use a scriptural quotation, 'taking from him that hath, and giving to him that hath not' or, in plain language, buying out the hill farmer lock, stock, and barrel. This 
is the problem which really confronts the whole question of hill aftorestation. The idea that suitable land in large compact blocks can be obtained without interfering with the present occupiers of such land is entirely unsound. In certain districts there are large areas possibly in the hands of one or two men, and the appropriation of such land need not involve the displacement of many persons. In other districts a few holdings, scattered over wide stretches of more or less suitable land for planting, are sufficient to block its conversion into forest, and these must be bought out before anything is done. Given the necessary compulsory powers, the acquisition of these two types of land could be effected without unreasonable trouble, but possibly not without considerable expense, in the same way as large areas have been acquired in England and Ireland for War Ofhice purposes, or in Scotland for afforestation. It might, at any rate, be regarded as well within the bounds of practical politics and economics, and by such means an area might be obtained of possibly 2,000,000 to $3,000,000$ acres, in individual blocks of 500 acres or more in size, in Great Britain, which would not involve the acquisition of useless land on the one hand or valuable agricultural soil on the other.

But to go beyond this area it is quite evident that a much more drastic process of expropriation would have to be adopted. However uneconomically estates may have been managed in the past, there is no great amount of evidence to prove that land of great value has been allowed to remain idle and uncultivated, apart from parks, ornamental woods, and deer forests of artificial origin. The agricultural land of Great Britain as a whole is used in the most economical manner possible under the existing conditions of the market for agricultural produce. The effect produced by the high price of wheat in the 'sixties' and 'seventies' is a fair instance of the way in which British 
agriculture adapts itself to temporary conditions of commerce, in spite of what critics may state to the contrary. At that period all classes of land capable of cultivation were broken up for wheat-cropping, and instances are recorded, such as that on the Bedford estate, of even woodland being cleared at enormous expense, only to be planted with trees again after the boom in prices was past. Every one knows that large areas exist in the shape of corners, strips, marshy bottoms, banks of rivers and ravines, etc., which might just as well be growing trees as not; but even this land is not as a rule absolutely waste, but is in most cases used for rough grazing, and probably brings in almost as high a return in that way as it would under anything in the timber line, apart from trees like larch, ash, or 1)ouglas fir. In any case, areas of this class could only be planted by the individual owner, and this form of afforestation deserves much greater encouragement from the State than it has hitherto received, bearing in mind the landscape and shelter effect produced by it upon the country generally.

The finding of the Royal Commission on Coast Erosion, to the effect that $9,000,000$ acres should be afforested in the British Isles, is doubtless sound in a way, for no sane individual can doubt that the country would not only be the better of more economically managed woodland, but also for the planting of land which would be, from an economic point of view, well suited for the purpose. But from the individual point of view it may well be asked what proportion of the agricultural population can be dispossessed of their holdings without inflicting hardships upon them or their fumilies? Take the case of a hill farmer, assisted by two or three sons, who holds about jo acres of arable and enclosed pasture, and a joint right to 1000 acres of mountain. The rental 
of a farm of this kind may be put at about $£ 50$ to $£ 80$ per annum, and the tenant may make from $£ s 0$ to $£ 150$ a year profit, according to season. Adding to the value of the stock an adequate sum for his interest in the holding, would probably leave him with about $£ 500$ or $£ 600$ in cash, a sufticient amount to start life afresh in a farming colony, perhaps, but not sufficient to allow him to experiment in a new business at home. Few men, again, who have lived the greater part of their lives on these holdings are inclined to emigrate, and there is little doubt that compulsory purchase on a large scale would lead to opposition, and an expression of public opinion sooner or later which would be fatal to the whole movement. What compensation would a man of this kind require for giving up possession of his farm? If turned out, he cannot reinvest his capital with any prospect of success in any other trade than that to which he has been reared, and besides cannot take another farm without displacing another man in turn. In cases where the views and inclination of the man himself happen to fit in with an afforestation scheme no trouble would be experienced, but such cases, although not uncommon, are certainly not universal.

The cost of purchasing land of this class would, again, be considerable. I'utting the compensation for disturbance as low as $£ 200$, and the landlord's price at $£ 1000$, a total of $£ 1200$ is reached per holding of about 300 acres or, in fee-simple, an average cost of about $\mathfrak{\&} 4$ per acre. If the whole area thus acquired were capable of profitable planting, this would not represent anything unreasonable; but in few cases would this be possible, and from one-fourth to one-half of any large area acquired would probably not yield a crop able to pay expenses, leaving any profit to come from the remainder. The actual productive area would thus be heavily burdened at the outset by its purchase at a cost of $£ 6$ to $£ 8$ 
per acre, according to the extent of useless land acquired with it.

The idea of the political economist is that the farmer should be gradually planted out-that is to say, that mountain land should be acquired in such a way that the progress of acquisition would be imperceptible, and the farmer himself almost unconsciously adapt himself, first to a restricted area; second, to no area at all. This theory, it is to be feared, for reasons already given, would not work out well in pructice. There would, at the outset, be the impossibility of economically fencing off one man's land from another's in the first place; and in the second place, fencing so as to suit both the convenience of the farmer and the planter at one and the same time. The majority of hillplanting work must begin at or near the base of the hill, owing to the fact that the better soil and situation there combine to create conditions favourable for the growth of the trees, and by the shelter afforded by the first crop enable the hill to be planted higher and higher, until the limit of profitable afforestation is reached. To plant the worst part of a mountain holding alone and obtain successful financial results is usually impracticable on a large scale, although it may sometimes be done in isolated cases.

While land, therefore, may be obtained at high elevations or of poor quality without interfering greatly with the agricultural population, owing to the limited extent to which the former is used, and the scarcity of the latter, economic difficulties at once increase when low-lying land, capable of producing profitable crops without risk, are being dealt with. The moment one gets away from the peat, heather, and bracken of the mountains, occupied holdings increase in number, value, and importance. Any approach of the purchasing negotiator for such lands is met with either blank refusal, or sale under such conditions as render the whole 


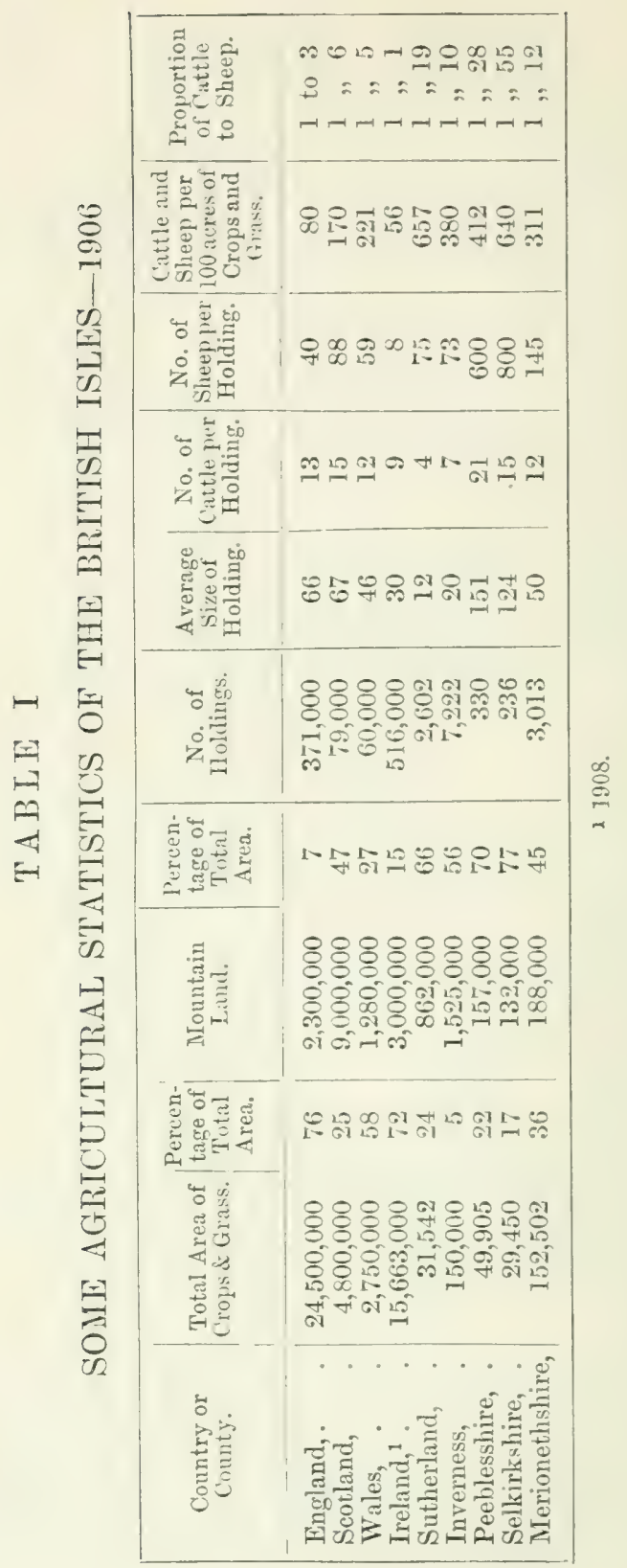





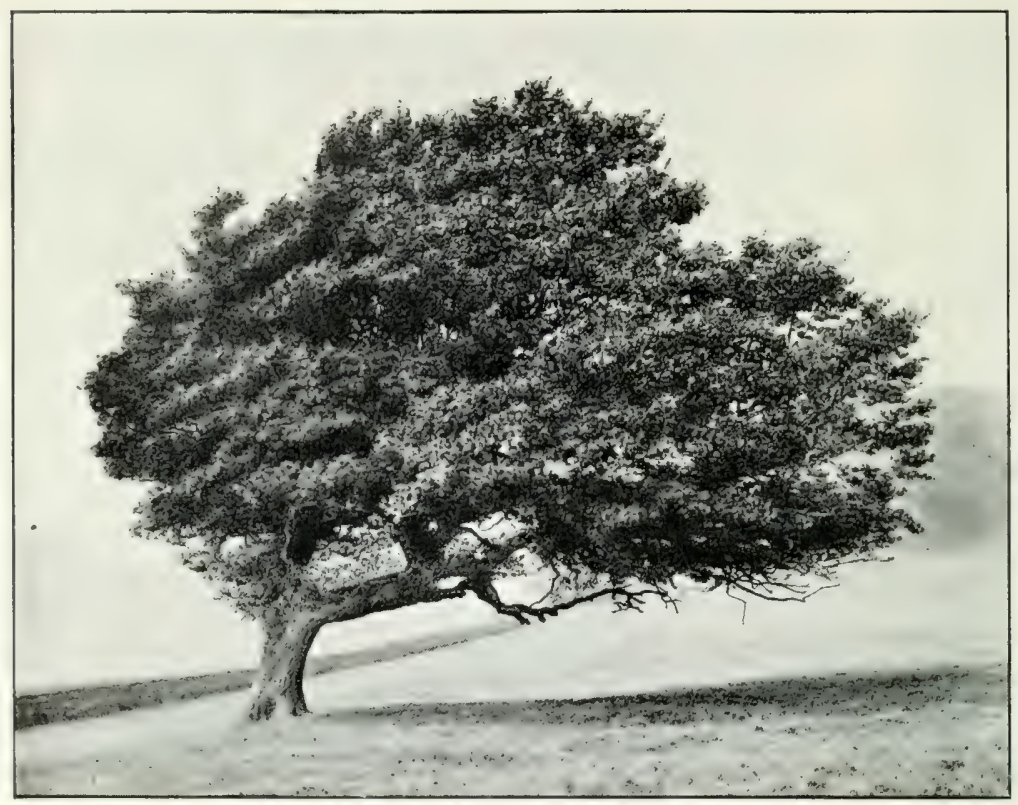

7. WIND-SWEPT LIMU NEAR SEA.

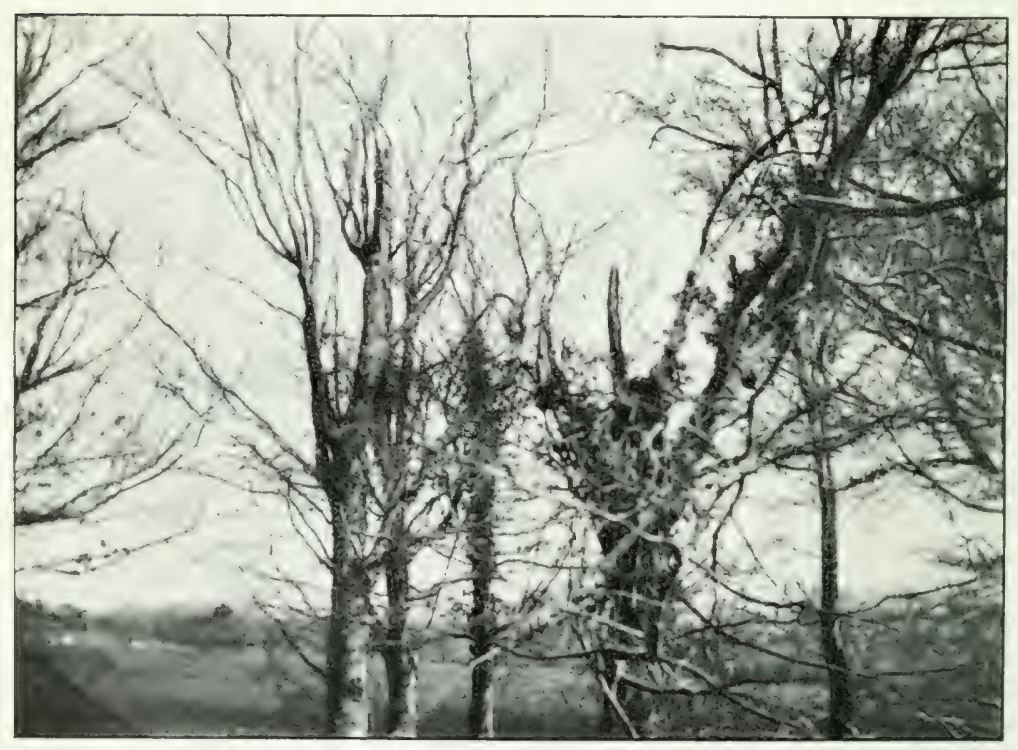

S. IEEH-[WI' KILIED HICK RY SEA WIND. 


\section{CHAPTER IV}

CLIMATE AND TREE GROWTH

THE three outstanding features which distinguish the climate of the British Isles from that of continental countries lying between the same degrees of latitude in NorthWestern Europe are mild, humid winters, cool summers, and a heavy autumn and winter rainfall. To every treelover familiar with the severe winters and frequent spells of heat and drought which characterise the weather in many parts of Europe, these features of the British climate at first sight would seem to be all that could be desired for the hardier evergreen and deciduous trees from a not inconsiderable portion of the world. When the fact is considered that most species from practically all parts of the warm temperate zone can find a home in the British Isles, one might be excused for drawing deductions, which are possibly more or less unsound, as to the suitability of the British climate for timber-growing. Thanks to the Gulf Stream, British winters are, taking the average of a number of years, proverbial for their mildness and absence of long spells of severe frost, and the extremes of summer and winter seldom differ to any great extent. A January day often shows a warmer and balmier air than a day in June, and it is no uncommon thing to find vegetation which has stood uninjured during eleven months of the year cut back and disfigured at a season when tradition learls one to assume that all should be smiling and gay. As a matter of fact, trees which require a relatively high winter temperature are certainly better 
oft in Britain than in most parts of the Continent, for a temperature approaching to zero F. would, if long sustained, be fatal to many of them, and it is possibly better to have half a tree than none. Species which one would only expect to find growing several degrees farther south may be seen of a respectable age and size in many parts of Britain, and an amateur is often inclined to attribute their success rather to the climate of the growing than to that of the resting season. To the gardener and arboriculturist this point is of special importance, for our mild winters enable them to enrich gardens and ornamental woodlands with an enormous variety of attractive and interesting species, to the admiration and envy of many of their continental neighbours. But to the practical forester it is really of little consequence whether the climate of the country can grow such a tree as the Eucalyptus, or many others of that class seldom seen so far north, for these trees can never attain, under the most favourable circumstances, the dimensions and character upon which their chief value depends for timber production.

For the forester, the climate of the country must be largely valued by its ability to produce the commoner timber trees, such as oak, ash, beech, pines, spruce, silver fir, larch, etc., of commercial dimensions in the comparatively short period of fifty to a hundred years, according to species. Judged on this particular basis, how does the British climate compare with that of France, Belgium, Germany, Holland, and others lying between similar latitudes? Enthusiasts tell us it will produce the finest timber in Europe. This may be so, but will it produce it at the same elerations, and on the same classes of soil as is the case in many parts of the Continent? This is the basis on which to test the superiority or inferiority, as the case may be, of the British as compared with the continental climate, and while we have neither reason nor right to dis- 
parage British weather, nothing is gained by refusing to look facts in the face, and ascertain as far as is possible the actual state of affairs. Two methods of investigation are available in this respect-one confining itself to the temperature, rainfall, and other climatic features of particular localities in various countries, and the other to the effects of these factors upon tree growth, as seen in the height and derelopment of isolated or massed specimens.

The principal climatic factors in promoting tree growth and timber production may be considered to be sufficient heat and moisture during the growing season. Heat associated with drought, or moisture with cold, are equally prejudicial to rapid growth, and while the most favourable amounts of heat and moisture vary with species and soil, they can be determined within certain limits in most countries. A favourable combination of heat and moisture, applied to a species in any given soil, results in the maximum production of leaves and wood during the season, and if repeated annually throughout the life of the tree, in the maximum height growth, and heariest production of timber possible for that particular species.

In a general way, an excess of heat over moisture favours the production of flowers and fruit at the expense of leares and wood, while an excess of moisture over heat has the opposite effect, but this is only true in a relative sense. The absolute production of either fruit or wood demands certain quantities of both these factors, and when either falls below the minimum, absolute and relative growth decrease. Mayr ${ }^{1}$ has laid down the principle that a mean temperature of $50^{\circ} \mathrm{F}$. during the four months of May, June, July, and August is necessary for the growth of trees to a height of 25 feet, and that timber trees will not grow where the rainfall falls below 2 inches

${ }^{1}$ Waldbau auf naturgeselzlicher Grundlage. 
for those months. He believes that the growth of most timber trees can be completed within six weeks under the most favourable conditions, but that no data are available to show what these conditions are, nor how far intensive light can replace heat in the process of growth.

So far as Britain is concerned, however, it is practically certain that the conditions are rarely favourable enough for growth to take place within such a short period. The actual time occupied in the increase of length of shoots of certain species is very short, but the maturing of wood and buds occupies a longer period, which is difficult to fix with any certainty. Oak, beech, pines, etc., seldom increase in length for more than three or four weeks in the latter part of May or beginning of June, and with the two first named this growth is often repeated in July in the form of midsummer shoots. Assinilation and the process of forming and ripening the wood go on until the end of August or possibly September, but visible growth in most species is much shorter than is generally supposed. Four months is more than sufficient for the growth and maturing processes of most species, and the actual time occupied in the formation of an annual shoot is rarely more than six to eight weeks. Exceptions to this are possibly larch, elm, hornbeam, willow, poplar, and alder, all of which grow so long as the temperature remains high enough. With these it is doubtful, however, if the growth made during the first and last month of the growing season is sufficient to make any appreciable difference, except to young plants which respond more readily to climatic conditions than older trees. Favourable conditions of temperature and moisture prevailing over a period of three months are probably sufficient to produce and mature a normal growth in all conifers, and the majority of broad-leaved trees.

The ripening of the seed depends more upon the length 


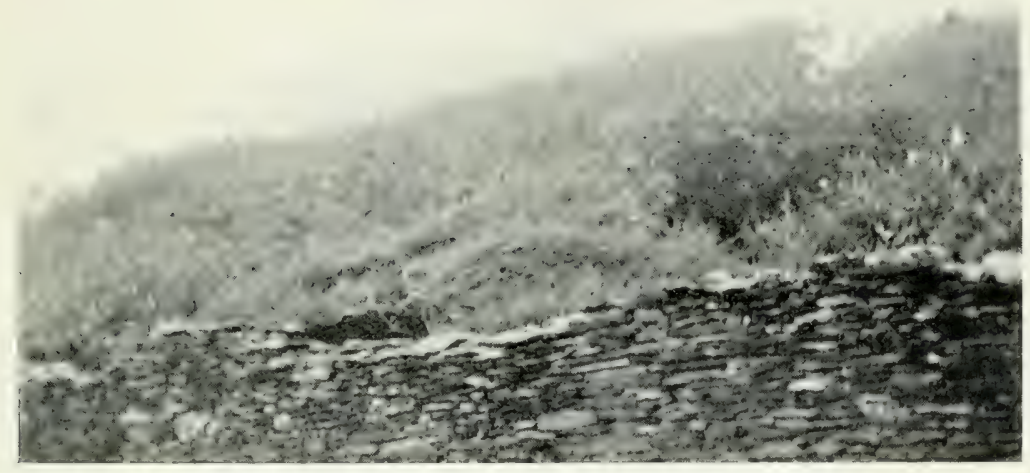

9. WINIWARD EIJGE OF WOOD ON WEST COAST OF IRELANI),

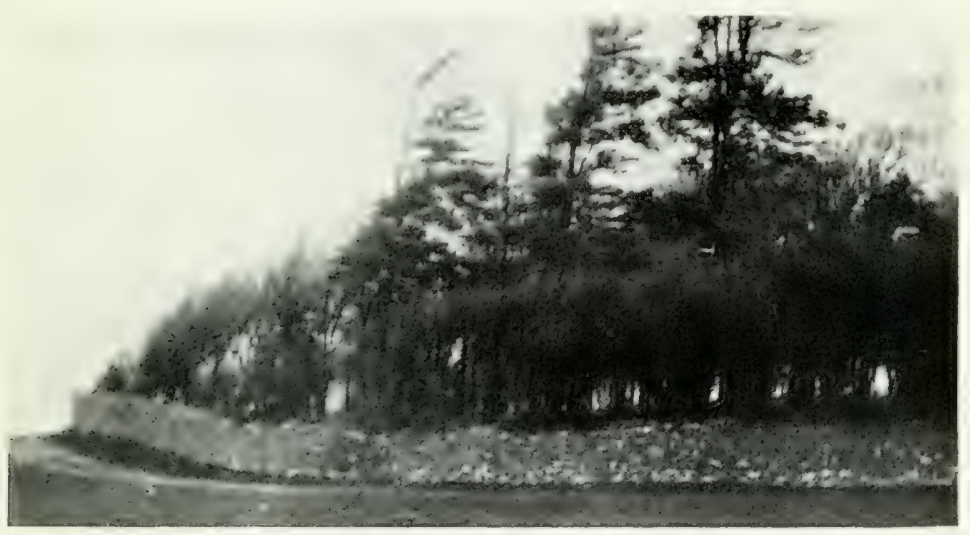

IO. BEECH AND SILVER FIR ON WINDWARD EDGE OF WOOD.

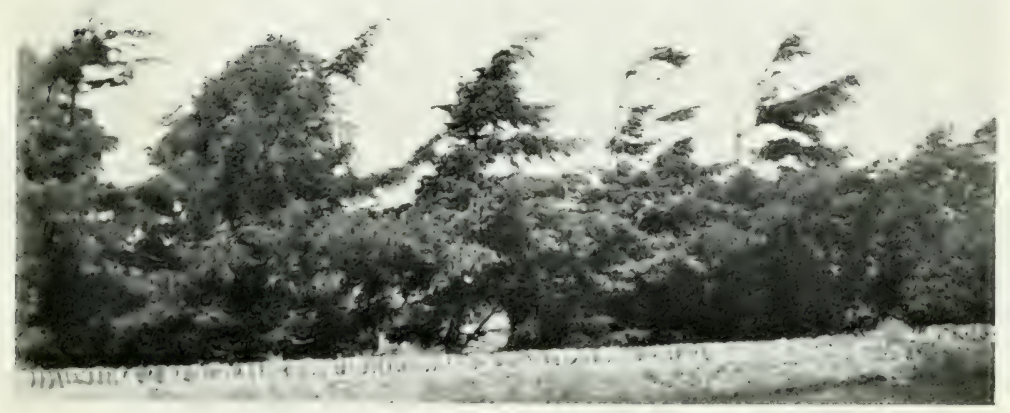

II. TOIS OF DOUGLAS FIRS DAMAGEI) HY WINI IN WEST HIGHIANIS, FIFTEEN TO TWENTY MILES FROM COAST. 

of the growing season, and possibly the assimilation and the formation of wood may proceed with a longer growing season than that of three months. Probably the larger size attained by trees growing in lower latitudes, as compared with those growing in the north, may be due to this cause. In the British Isles, however, perceptible growth in late leafing forest trees can scarcely be said to begin before June in an average season. With early leafers the growth made in May is frequently destroyed by frost, so that any gain in the period between the beginning and end of growth is lost. Growth after August again is often seen in the species already named, as larch, poplar, willow, etc. Occasionally other species, either owing to habit, accident, special weather conditions, etc., make a second growth in July or August, as the oak or beech, but this growth is usually completed in a month or six weeks. A second growth in conifers often takes place in larch, Douglas fir, pines, and spruce, but may be considered more or less abnormal.

If the three months of June, July, and August are taken as the true growing season, an examination of records of rnean temperature show that July is almost invariably the hottest month, or that in which the monthly maxima and means culminate. So far as the north-west of Europe is concerned, the amplitude or range of mean temperatures of these three months does not exceed $10^{\circ} \mathrm{F}$, and in most instances does not exceed $5^{\circ} \mathrm{F}$. In all cases the mean temperature of July may be regarded as an index to that of the other two months, and a station showing the highest record for that month may be regarded as enjoying the hottest summer. The following table gives the July means for a number of stations in Northern Europe, and it will be seen that the coolest Julys are experienced in Scotland and Ireland, and the hottest in Berlin:- 


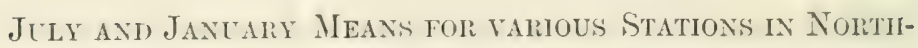
Western Europe from Hann's Hundbuch der Kilimatologie, and Meteorological Office records.

Low-Level Stations

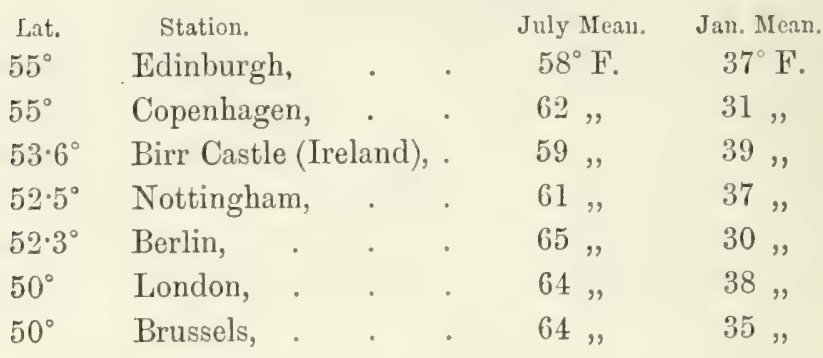

The question then arises as to the climate most nearly approaching perfection for those species which are of greatest importance in British forestry. The range of amplitude in July mean temperatures varies generally from $54^{\circ} \mathrm{F}$. in the north of Scotland to $62^{\circ} \mathrm{F}$. in various districts in the south, east, and midlands of England, or, roughly stated, a difference of about 9 . The British Isles, therefore, may be divided into three climatic groups, in each of which certain species are found to succeed better tham others, as shown in the following table:-

Climatic Groups in British Isles as indicated by July Means and the development of certain species of trees.

July Means of $54^{\circ}$ to $56^{\circ} \mathrm{H}$.

Species thriving best in these are spruce, Sitka spruce, larch, birch, etc. Spruce and larch seldom attain large dimensions on exposed sites with these temperatures.

II

July Means of $57^{\circ}$ to $59^{\circ} \mathrm{F}$.

Most suitable species are the majority of conifers, ash, beech, 
sycamore, etc. In this group Pinus insignis and Cupressus macrocarpa do well where the winter extremes do not fall below $10^{\circ}$ to $0^{\circ} \mathrm{F}$.

\section{III}

July Means of $60^{\circ}$ to $62^{\circ} \mathrm{F}$.

Species developing best are oak, English elm, Spanish chestnut, cedars, walnut, plane, Robinia, etc.

The species named in each of the groups are those which best reflect in a general way, the climatic features in their growth and development. With the exception of the four last species, all are capable of reaching timber dimensions in any part of the British Isles, and given suitable soils and situations, trees of large dimensions may be found in most parts. But to the careful observer it is evident that the farther north one travels the smaller become the species associated with the third group, and corresponding to the July mean of $60^{\circ}$ to 62 . North of Yorkshire the English elm ceases as a common tree of large size. Planes and cedars are scarce and poorly developed in Scotland. Walnut and chestnut cease to ripen their fruit north of the midlands, and Robinic fails altogether in Scotland and Ireland as a timber tree.

In the first of these climatic groups or localities the greater part of the north of Scotland may be placed. In the second, most districts in the south of Scotland, north of England and north of Ireland, and in the third, average localities in Wales, the midlands and south of England, and south of Ireland. The differences due to altitude depend largely upon latitude. As seen from the following list, all localities above 800 or 1000 feet possess temperatures approximating to those in Group I. until, at about 1500 feet, summer temperatures requisite for tree growth, according to Mayr, probably cease altogether. 


\section{July Means at High-Level Stations}

(From various authorities)

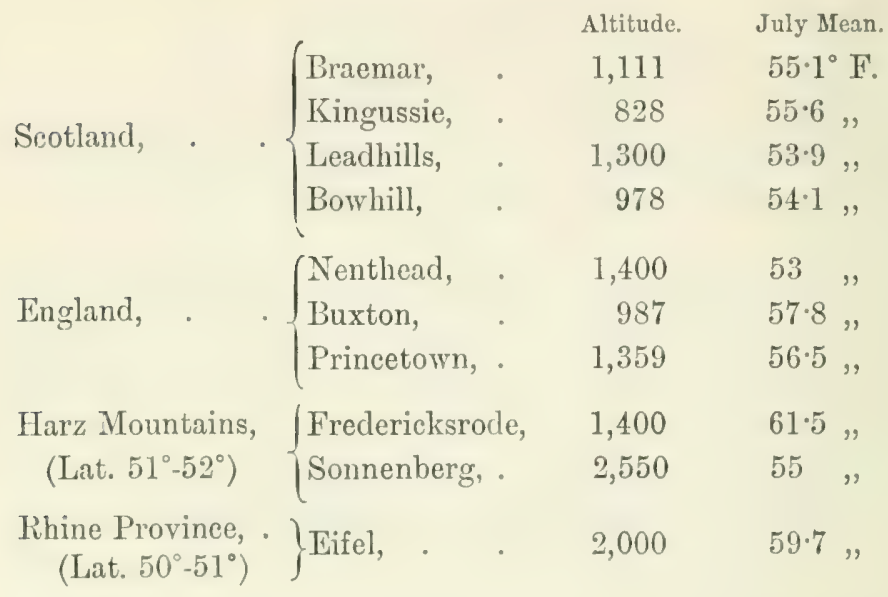

Until, however, a number of properly equipped meteorological stations are established at high altitudes nothing of a definite character can be known about our hill climates.

Dr. Shaw has suggested that the mean temperatures at high altitudes might be ascertained by extra-polation from lower stations, basing the calculations on the generally established fact that the temperature falls 1 F. for every 300 feet. But this method does not enable the effect of wind, which increases in force and frequency rapidly with altitude, to be fully ascertained, and weather stations could alone decide the actual conditions present. At the present time, almost the whole of the meteorological stations throughout the country are below the 800 feet level, and consequently the climate indicated by systematic observations extending over any lengthened period is that of the low-lying and more or less sheltered lands. The regular stations above this level reporting regularly to the 
Meteorological Office, the Royal Meteorological Society, or the Scottish Meteorological Office, do not appear to be more than six in number, four of which are in Scotland, and two in England. No station of this kind exists in either Wales or Ireland, the highest in the former being 550 feet and in the latter 212 feet above sea-level. Records of rainfall alone are taken at a number of high-lying stations throughout the United Kingdom, but these observations are of little value unless associated with those of temperature.

Concerning the rainfall generally, there is no reason to suppose that the British Isles are inferior to the remainder of Europe, and many parts of them certainly possess a much more abundant fall. In the west of Ireland and Scotland the summer rainfall varies from 12 to 15 inches, while throughout the greater part of the country it is seldom below 10 inches. The lowest rainfall occurs in the extreme south and east of England, and probably the growth of many species, especially conifers, is adversely affected by its deficiency. Common and Sitka spruce, larch, and a few others of that class, do little good on dry soils south of the midlands, unless growing on northern slopes, or in exceptionally cool localities. For the development of most broad-leared species and the dry-soil types of conifers, however, rainfall, apart from exceptionally dry years, is usually ample in all parts of the country.

At different centres, of course, rainfall varies considerably. In the west of Scotland, Ireland, and lake districts of Cuimberland from 50 to 100 inches are recorded annually in many districts, while in the south and east of England the annual fall may not exceed 20 inches. The summer rainfall of May, June, July, and August varies from 6 to 15 inches, as shown in the following table:- 
Average Rainfall during the four Sumer Months of May, June, July, and August at various Stations in the British Isles. (From records of Meteorological Office.)

\begin{tabular}{|c|c|c|c|c|c|c|}
\hline & & $\begin{array}{l}\text { MIay. } \\
\text { In. }\end{array}$ & $\begin{array}{l}\text { June. } \\
\text { In. }\end{array}$ & $\begin{array}{l}\text { July. } \\
\text { In. }\end{array}$ & $\begin{array}{c}\text { Angust. } \\
\text { In. }\end{array}$ & Total. \\
\hline Braemar, . & . & $2 \cdot 30$ & $2 \cdot 38$ & $2 \cdot 83$ & $3 \cdot 78$ & $12 \cdot 40$ \\
\hline Glasgow, . . & . & $2 \cdot 42$ & $2 \cdot 83$ & 3.35 & $4 \cdot 06$ & $12 \cdot 66$ \\
\hline Leith, . . & . & $1 \cdot 67$ & 1.92 & $2 \cdot 77$ & $2 \cdot 89$ & $9 \cdot 25$ \\
\hline Buxton, . . & . & $3 \cdot 27$ & $3 \cdot 42$ & $4 \cdot 12$ & $4 \cdot 66$ & $15 \cdot 47$ \\
\hline Nottingham, & - & 1.92 & $2 \cdot 17$ & $2 \cdot 60$ & $2 \cdot 61$ & $9 \cdot 30$ \\
\hline Birr (Ireland), & . & $2 \cdot 19$ & $2 \cdot 47$ & 3.02 & 3.97 & $11 \cdot 65$ \\
\hline Cambridge, . & . & $1 \cdot 84$ & $2 \cdot 24$ & $2 \cdot 47$ & $2 \cdot 39$ & $8 \cdot 94$ \\
\hline Shoeburyness, & . & $1 \cdot 29$ & $1 \cdot 79$ & 1.81 & $1 \cdot 75$ & $6 \cdot 64$ \\
\hline
\end{tabular}

From 6 to 9 inches during the summer may be regarded as characteristic of a dry climate, from 9 to 12 inches as an average, and over 12 inches as a wet climate. The first named is best suited for deep-rooting, broad-leaved trees. The elm, oak, plane, walnut, Spanish chestnut, etc., usually do fairly well with dry summers, while the Scots pine, Corsican and Austrian amongst conifers may thrive. For the majority of conifers, however, a summer rainfall of not less than 9 or 10 inches is necessary to produce good growth, unless the soil is naturally damp and cool. Temperature, however, influences the effect of rainfall considerably, and the lower the former the less rain is required to maintain a slow but continuous growth over a limited period.

The theory that the more rain the better trees grow in Britain is fallacious. Certain species succeed best with 
abundance of moisture, but it must be accompanied by a certain temperature, shelter from strong winds, and a porous soil, which may or may not be forthcoming on a given area. The greatest amount of rain falls at high elevations, and as is well known, tree growth at the the latter is slower than at low levels, or ceases altogether at elevations of 2000 feet or so. In sheltered positions within 500 feet of the sea-level, many conifers grow better with the heavy rainfall of the west coast than elsewhere, but a porous soil is absolutely necessary for the success of most. Many broad-leaved trees, on the other hand, attain a poor derelopment, or fail altogether in similar situations.

As regards the height growth of trees, the most farourable index of climatic influence, data are more difficult to obtain which are free from differences of soil and situation. The yield tables of continental forest statistics give us the height growth of thickly grown crops at various ages, and from these we can form some idea of the ultimate height growth attained by mature crops in average localities in North-Western Europe. Data for Scots pine, spruce, and beech are found in the table on page 232.

Statistics of British tree growth are more difficult to obtain, except those relating to individual trees, and these refer in many cases to those either remarkable for their large girth or rarity, or trees which have been grown under exceptionally favourable contitions. In any case, they are seldow strictly comparable to the average continental yield tables. Such, for instance, as have been collected from various sources furnish the data shown in the following table as regards height growth alone:- 


\section{T A B L E II}

Maxincur Henght Growtins of Comion Forest Thees IN BRITish Isles when growing under favourable conditions, and of individual trees, as recorded by —*Elwes and Henry: ***Author: +Various records and observers.

\begin{tabular}{|c|c|c|c|}
\hline Species. & England. & Scotland. & Ireland. \\
\hline Ash,. . & $\begin{array}{l}\text { 130-160 feet. } \\
\text { **120 Longleat. } \\
\text { *146 Cobham. }\end{array}$ & $\begin{array}{l}\text { 100-120 feet. } \\
\text { +121 Miln-Graden. } \\
\text { *134 Mountstuart. }\end{array}$ & $\begin{array}{l}\text { 100-120 feet. } \\
\text { * } 112 \text { Dundrum. } \\
\text { *127 Woodstock. }\end{array}$ \\
\hline Beech, . & $\begin{array}{l}\text { 110-120 feet. } \\
\text { *135 Ashridge. } \\
\text { *120 Cornbury. } \\
\text { +116 Chatsworth. }\end{array}$ & $\begin{array}{l}100-110 \text { feet. } \\
\text { +122 Dunglass. } \\
\text { *117 Blair-Drummond. }\end{array}$ & $\begin{array}{l}100-110 \text { feet. } \\
\text { +110 Carton. } \\
\text { *120 Woodstock. }\end{array}$ \\
\hline Oak, . . & $\begin{array}{l}\text { 100-120 feet. } \\
130 \text { Kyre. } \\
\text { *130 Whitfield. }\end{array}$ & $\begin{array}{l}\text { 80-100 feet. } \\
\text { †110 Hopetoun. } \\
\text { *118 Blair-Drummond. }\end{array}$ & $\begin{array}{l}\text { 80- } 100 \text { feet. } \\
\text { **100 Carton. } \\
\text { *118 Coolattin. }\end{array}$ \\
\hline Larch, . . & 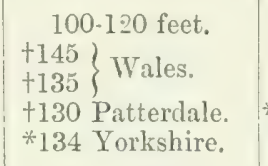 & $\begin{array}{l}\text { 120-140 feet. } \\
\text { +143 Kirkpatrick. } \\
\text { +140 " } \\
\text { **130 Inverary. } \\
\text { *125 Dunkeld. }\end{array}$ & $\begin{array}{l}\text { 120-140 feet. } \\
\text { **130 Kilworth. } \\
\text { **120 Glasslough. }\end{array}$ \\
\hline Spruce, . & $\begin{array}{l}\text { 100-130 feet. } \\
+130 \text { Studley. } \\
\text { +120 Woburn. }\end{array}$ & $\begin{array}{l}\text { 100-120 feet. } \\
\text { **130 Inverary. }\end{array}$ & $\begin{array}{l}\text { 100-120 feet. } \\
\text { **110 Kilworth. }\end{array}$ \\
\hline Silver Fir, . & $\begin{array}{l}120-140 \text { feet. } \\
140 \text { Longleat. } \\
140 \text { Hartburn. }\end{array}$ & $\begin{array}{l}100-120 \text { feet. } \\
140 \text { Inverary. }\end{array}$ & $\begin{array}{l}\text { 110-130 feet. } \\
\text { **130 Cookstown. } \\
\text { **125 Avondale. } \\
\text { *133 Woodstock. }\end{array}$ \\
\hline Scots Pine, & $\begin{array}{l}\text { 80-100 feet. } \\
\text { *100 Colesborne. } \\
\text { *120 Petworth. }\end{array}$ & $\begin{array}{l}\text { 60-80 feet. } \\
\text { **115 Inverary. } \\
\text { *110 ,. }\end{array}$ & $\begin{array}{l}\text { 80-100 feet. } \\
\text { **120 Curraghmore. } \\
\text { **120 Kilworth. } \\
\text { *95 Doneraile. } \\
\text { **90 Abbeyleix. }\end{array}$ \\
\hline Douglas Fir, & $\begin{array}{l}\text { 100-120 feet. } \\
\text { *137 Powis Castle. } \\
+127 \text { Dropmore. }\end{array}$ & $\begin{array}{l}100-120 \text { feet. } \\
\text { t110 Durris. }\end{array}$ & $\begin{array}{l}\text { 100-120 feet. } \\
\text { **110 Powerscourt. }\end{array}$ \\
\hline
\end{tabular}

1 Captain Gethin states that a Scots pine blown down a few years ago near these trees measured 135 feet in length. 


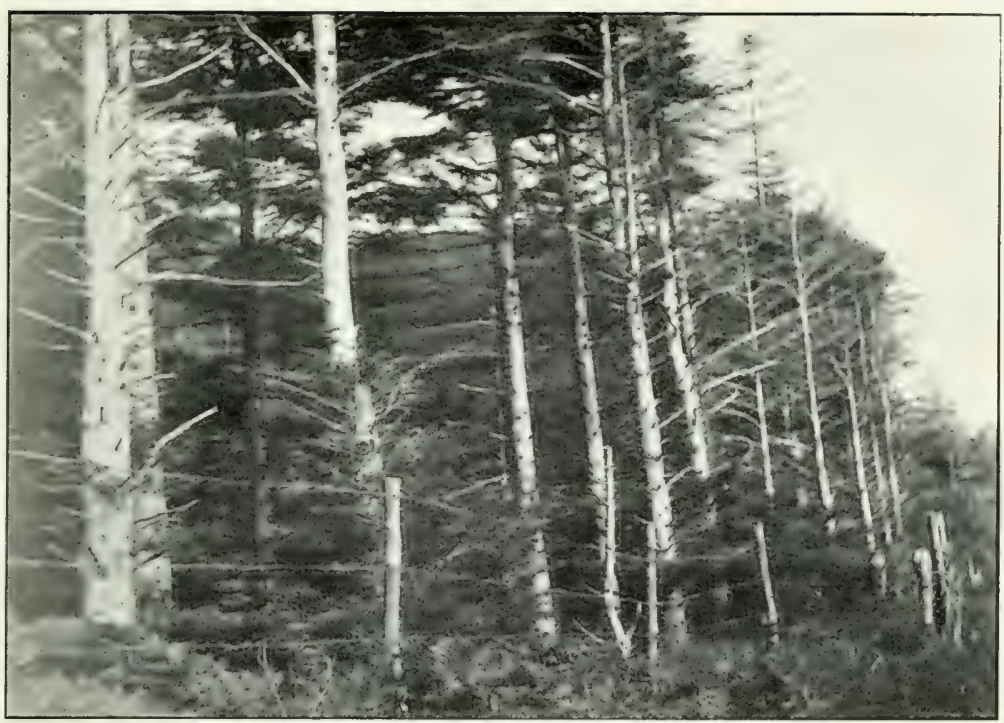

12. EDGE OF SILVER FIR WOOI) NEAR SEA.

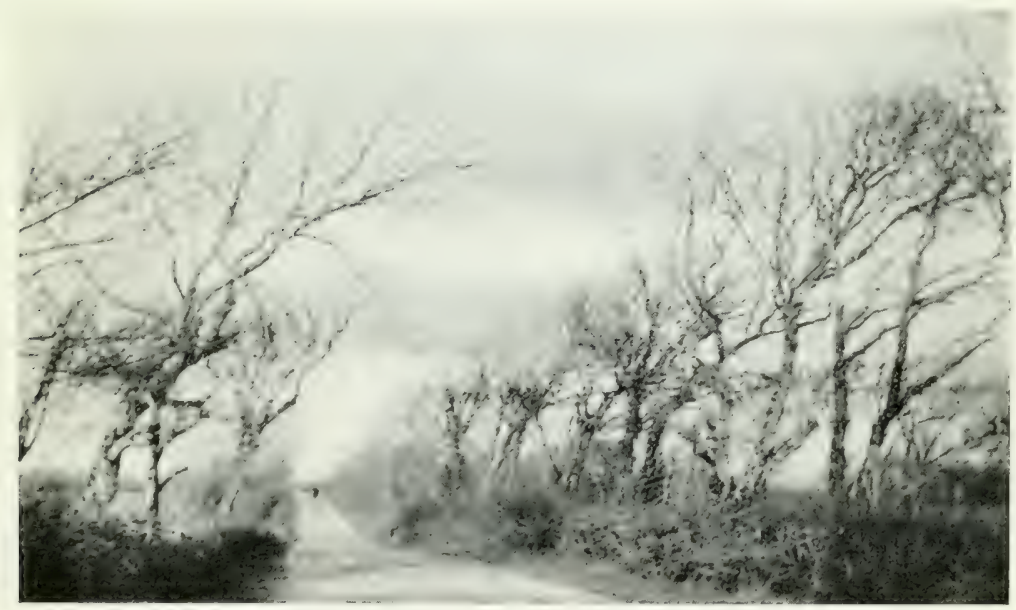

13. ASH ON GOOI) GROUNI) - TEX MILES FROM WEST COAST. 

In this table exceptionally tall trees only are mentioned, such as may occur in one or two places only throughout the Uniterl Kingdom. The soils and situations in which they were grown could not always be ascertained, but all the British records were probably obtained within 500 or 600 feet of sea-level, and certainly in favourable localities. So far as they go, they indicate no inferiority of soil or climate in Britain at low levels, but the development of trees at high altitudes on the Continent has no parallel in Great Britain.

In Austria, for instance, only 3 per cent. of the State and 'endowment' forests are below 1000 feet elevation; 15 per cent. between 1000 and 2000 ; 2.) per cent. between 2000 and $3300 ; 41$ per cent. between 3300 and 5300, and 14 per cent. over 5300 feet respectively. In France 47 per cent. of the State forests are between 1000 and 2000, 35 per cent. above 2000 feet. $^{1}$

Individual trees of silver fir in France (Vosges) are recorded up to 163,158 , and 144 feet in height at an elevation of 3000 feet. Oak in the Spessart reaches a height of 150 feet at 1000 to 2000 feet above sea-level, and spruce throughout Central Europe generally attains its greatest dimensions at elevations well above the limit of tree or even shrub growth in Britain.

The girth or diameter growth of trees is probably more the effect of soil and age than climate, although the latter necessarily comes into play in the case of all growth. Mere girth, unarecompanierl by height, however, camnot be regarded as a sitisfactory index of climate. The greatest girths are usually seen in short-boled and large-crowned trees, or in pollards which have been repeatedly cut back, and compelled to put on wood over a limited stem area. Trees which have forked near the ground also show a large girth in most cases, and these have little or nothing to.do with the climate as a distinct factor of growth. 
In all instances of large tree growth, the peculiar conditions under which the trees have been growing must be considered. Practically all localities have a local climate of their own, good or bad as the case may be, which may be quite distinct from the general climate of the surrounding district. Deep valleys, ravines, and hollows in hill ranges usually possess these local climates, the chief features of which are shelter from prevailing wind, and frequently exceptionally favourable soil conditions. Olserrations confined entirely to the largest trees in any district, therefore, may lead to quite erroneous conclusions being formed as to the general suitability or otherwise of the local climate for timber-growing, and probably many mistakes of this kind have been made in the past.

But, apart from actual data, observations made in different parts of the country will quickly convince one that the growth of most trees in the British Isles is very greatly affected by wind currents, a factor which has not been so carefully recorded in meteorological observations as rainfall and temperature. The more westerly the aspect and isolated the tree, the higher the elevation and the poorer the soil, the greater becomes the effect of wind, and whilst its influence is felt all over Western Europe, it would require a strong imagination, and a blindness to actual facts to assert that the British Isles were not more exposed to westerly winds than countries farther east. If a strip of country be taken within fifty miles of the western coast of Europe, starting at Jutland in the north, and extending as far south as Gascony in France, it would be no exaggeration to state that tree growth on exposed sites in that belt is retarded from 20 to 50 per cent. from westerly winds alone. This may not be due to the course or prevalence of the winds altogether but partly to the salinity of the air, which is sufficiently strong to turn the needles of conifers in winter, or the 
leaves of deciduous trees in summer, red and brown in a few hours. The Scots pine, larch, and spruce are particularly liable to this injury, and probably few but the more typical maritime trees are exempt from it.

Taking the British Isles by themselves, the wind inHuence is aggravated by the fact that they stand out in the Atlantic sufficiently far to derive the special benefit or disadvantage, according to the point of view from which they are studied, from Atlantic gales. Probably this would he evident still more clearly if it were not that the greater part of the coast-line of Scotland, Wales, and Ireland is occupied by mountain chains which tend to break the full force of the wind in many districts. The more broken the ground the more frequently will severely exposed and exceptionally sheltered spots alternate, and the fact that trees frequently do well in the latter is brought into greater prominence than the equally obvious fact that the growth on the former is slow, stunted, and unprofitable.

Trees grown in thick masses on comparatively level ground suffer least from winds of an ordinary character, and when it is possible to obtain land of this character the adverse components of British climate, so far as wind is concerned, may be practically counteracted. But in most districts, especially those on the western side of the British Isles, flat land is not a common feature, and what there is of it cannot be given up to tree-growing. This side of England and Wales, Scotland and Ireland certainly has its advantages, for it provides a number of sheltered valleys and slopes which, if use is made of them, enable trees to be grown to a satisfactory size, and at a fairly rapid rate, within a few miles of the coast-line. The humid atmosphere of such districts again is particularly favourable to many species of conifers, especially those from the Pacitic slopes of North Anerica, like Duuglas tir. 
Sitka fir, Thuiu, etc., and also to such European trees as are indigenous to a high altitude or latitude, where the summers are cool and moist. Hence is it that Ireland, Wales, the lake districts of England, and the West Highlands of Scotland furnish numerous examples of rapirl and luxuriant growth so far as these species are concerned. The success of trees of this class is well demonstrated on such estates as Inverary and Benmore in Argyllshire, Achnacarry in Inverness-shire, and Castle Kennedy in Wigtownshire. On these estates good sites and sheltered situations provide some of the finest examples of tree growth in Scotland, yet in no place are trees of any size to be found above 700 or 800 feet above sea-level, where wind and general climate again assert their influence. Instances like these have probably assisted in forming the theory that the British climate is all that could be desired for most species of trees, independently of soil and situation.

But take the other side of the picture, which, in these cases, means the other side of the hill or the other end of the valley, as the case may be, and what is found? Examine any wood, clump, belt, or single tree on a western or southern slope within 50 or even 100 miles of the western coast-line of Great Britain, and one invariably finds that the luxuriant growth of the eastern slopes and sheltered valleys is here replaced by a dwarfed, stunted. and leaning habit of growth, which increases with the elevation, poverty of the soil, and susceptibility of the species to wind and exposure. Growing in thick masses may here as elsewhere tend to minimise the effect of wind and lack of summer heat, but only to a limited extent, and it is erroneous to assume that the storm-swept and wind-tortured growth, which is so characteristic of trees on exposed sites near the sea, is entirely eliminated in large plantations, although it is undoubtedly decreased. No precise data have yet been collected on the com- 


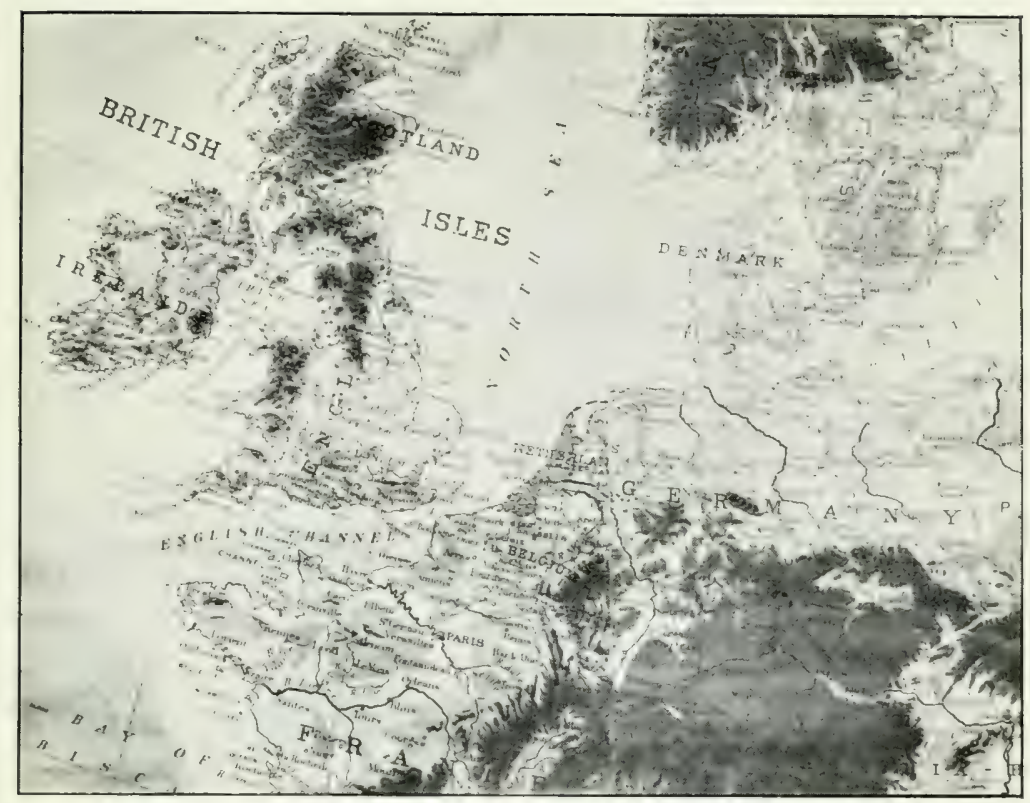

14. Physicai, Map of North-IVestera Eurole.

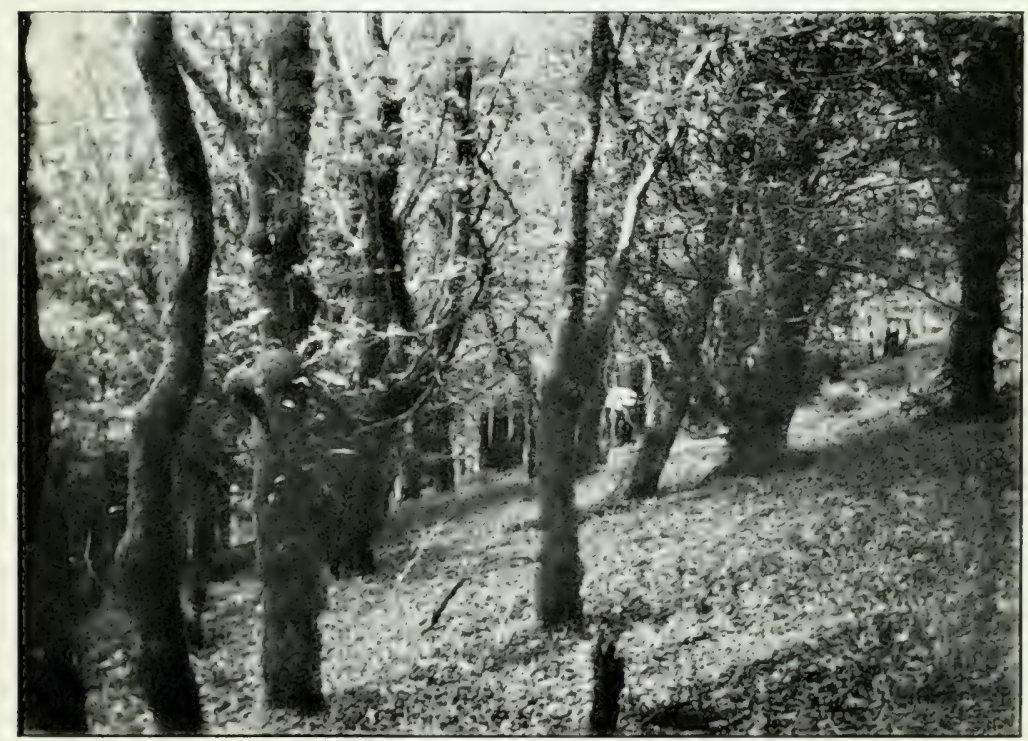

I5. BEECH ANI OAK ON WESTERN SLOPE. IREIANID-SOO FT. 

parative rate of growth on exposed and sheltered sites of the same mountain range. The difficulty in obtaining such data would be the variation in soil conditions which might prevent exactly parallel localities, other than those associated with exposure, to be obtained, but the olsserver knows only too well that the results of strong winds are beyond all dispute, and that at least two-thirds of the total surface of the land are affected by them.

The general effect of such exposure is that mountain land in Great Britain and Ireland is incapable of growing large timber above 700 or 800 feet, apart from glens, exceptionally good soil, or eastern aspects. By large timber is meant, of course, trees which will pay for sawing into boards or scantlings, and leave something over for the estate-owner. Pit props, fencing timber, etc., can be produced at higher elevations, but at present prices it is practically impossil)le to grow trees at a protit which do not attain a total height of more than 50 feet, and an average cubic content of more than 10 or 12 feet. Along the eastern side of the country the effect of the wind diminishes, particularly on goorl soil, but it is still easily seen on the extreme eastern sea-board in places, particularly in long valleys running east and west, and on highlying tablelands. Talie the country between the Solway and Neweastle-on-Tyne, that between Edinburgh and (ilasgow, or the Centril Plain of Ireland, and it is dificult to notice any great decrease in the effect of wind upon tree growth as one travels east. Within a few hundred yards of the east coast, trees show more or less the effect of the east wind off the sea, but further west the prevailing wind again asserts itself, and few situations are exempt from its influence. The influence of wind increases with the height of the trees anil elevation of the ground: and, according to Stevenson, an increase of nearly 100 per cent. takes place in the velocity of the wind at 50 feet 


\section{THE DEVELOPMENT OF BRITISH FORESTRY}

above the ground, as compared with that at ground-level. With good wind-resisting species, as ash, beech, Corsican pine, silver fir, etc., the effect of wind is greatly counteracted by good soil, and timber of respectable size can be grown up to 1000 or 1200 feet in inland counties, but at these elevations good deep soil is, of course, exceptional.

Nuch importance is also attached to the fact that trees on the edge of a wood are most affected by wind, and it is assumed that belts of suitable species can render the plantation behind not only immune against wind damage, but are also able to counteract the usual effects of wind upon the growth and height of the trees. On flat land this is, of course, to a great extent the case, and in a plantation of any size the trees gradually increase in height as they recede from the windward edge of the wood. In exposed districts this gradual rise of the tree crowns occurs at an angle of about $45^{\circ}$ with most species, trees such as silver fir and ash rising more rapidly. But on slopes facing the wind the effect of a shelter screen upon the ultimate height growth of the trees is very slight. The influence of an older screen, however, upon the young crop for the first few years can scarcely be over-estimated, and success in many situations depends almost entirely upon the provision and maintenance of such trees at regular intervals. While, howerer, much can be accomplisher by judicious treatment in this way, the fact still remains that wind is a powerful factor in preventing tall, straight stems, and a prolonged height growth is only possible below the 500 feet contonr line, or in situations sheltered by surrounding ground, as in valleys on north-east slopes, and other sites possessing a local climate of their own.

Given similar soils and situations, and considering the growth of the hardier trees alone, there is probably no great difference between British and continental climates 
during the first twenty years or so. But after that stage persistent wind, a clouded sky, and the absence of intense insolation tend to check the height, growth, and development of most species, and the result is a diminutive yield of timber per acre, in a rotation of eighty or a hundred years, compared with that obtained in continental forests. On cold soils and exposed situations this diminution is most marked, while in sheltered valleys and warm soils it may disappear altogether. But the average growth of a large number of plantations will certainly show it if carefully observed, whatever may be the numerous theories held on this subject by various authorities.

To the planter of trees, no doubt, the British climate is decidedly favourable. Cold and wet springs and summers, though not universal, are certainly common enough to give the planter a fair measure of success, provided he takes reasonable precautions, and avoids the common mistake of planting trees, which, through root exposure and other causes, are practically dead already. Nild winters induce root action to proceed more or less from October to March, and the absence of long spells of dry, cold wind prevent the withering process to which plants are liable when their root systems have been interfered with. The planting season in Britain, therefore, is not, only long, but is carried on under more favourable conditions than in many parts of Europe. Possibly its favourable character in this respect is responsible for that general carelessness which seems to permeate nursery and planting work in this country. Liberties are taken in the lifting, handling, packing, transit, and replanting of trees which can only be attributed to ignorance on the one hand, or to a great confidence in luck on the other, but these matters will be more fully dealt with elsewhere. The general absence of snow and frost for long periods enables planting operations to be carried on from October 
to April with every chance of success, and on many soils, autumn planting, provided ground game is absent, is an enormous advantage.

Considering the climatic conditions of the growing season in detail and their effect upon the tree as a whole, the following description of the peculiarities of the British climate nay be given. Our springs, in common with the springs of most temperate climates, are proverbial for their fickleness and sudden changes of temperature. Regarding March, April, and May as the spring months, it is not uncommon to find the coldest and warmest days of the whole year within their limits. Sleet, rain, snowstorms, blizzards, piereing winds, sharp night frosts, biting air, dead calms, clouded skies, and hot suns are all features of March, in spite of the fact that cold, dry, blustering winds from the east are usually associated with it in the popular mind. Warm March weather is often responsible for the premature leafing of easily exciter trees, as larch, horse chestnut, etc. When this happens damage usually follows from frost or cold later on, night frosts of $10^{\circ}$ to $15^{\circ} \mathrm{F}$. being not uncommon at any time during the month. So far as vegetation is concerned, a cold March is distinctly beneficial, for the longer the growth of tender trees is delayed, the greater the chance of their escape from injury later on, and it is seldom, if ever, that March cold has been known to do any harm to established trees. To the planter, however, a cold, dry II arch often meaus a loss in recently transplanted conifers, especially those of large size, while the risk of moving trees in that month is usually above the average, apart from nursery work, for which dry weather is often preferable to wet. Still, take it all round, the forester (annot complain greatly about March weather whatever it may be, for it is seldom that his troubles can be directly traced to it. 



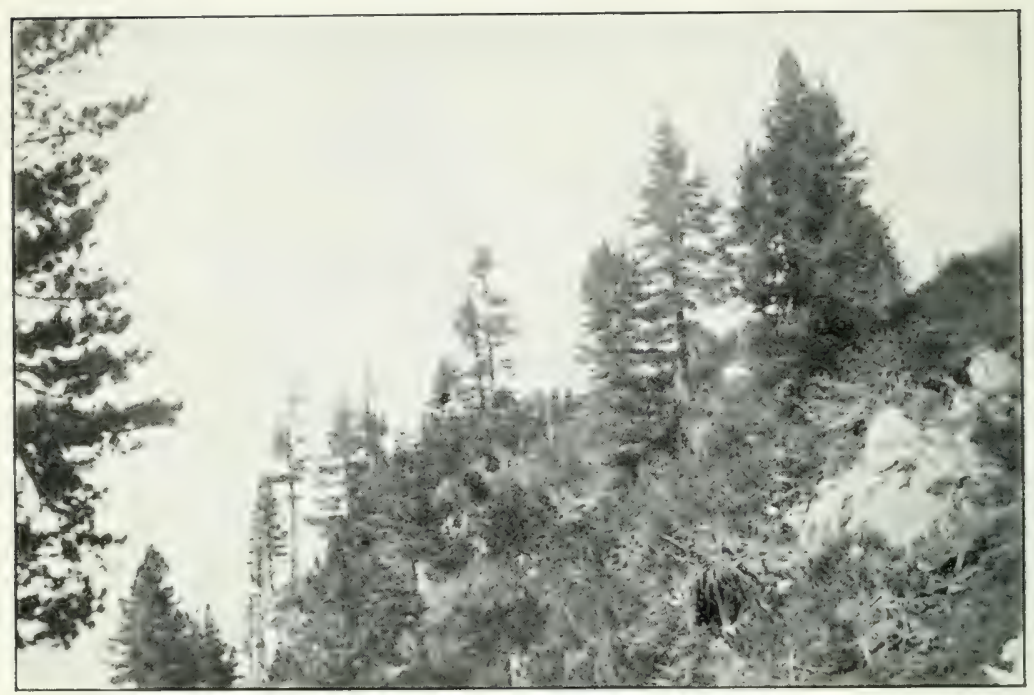

16. Cembrain Pixe in Bavariay Alts-6,000 Ft.

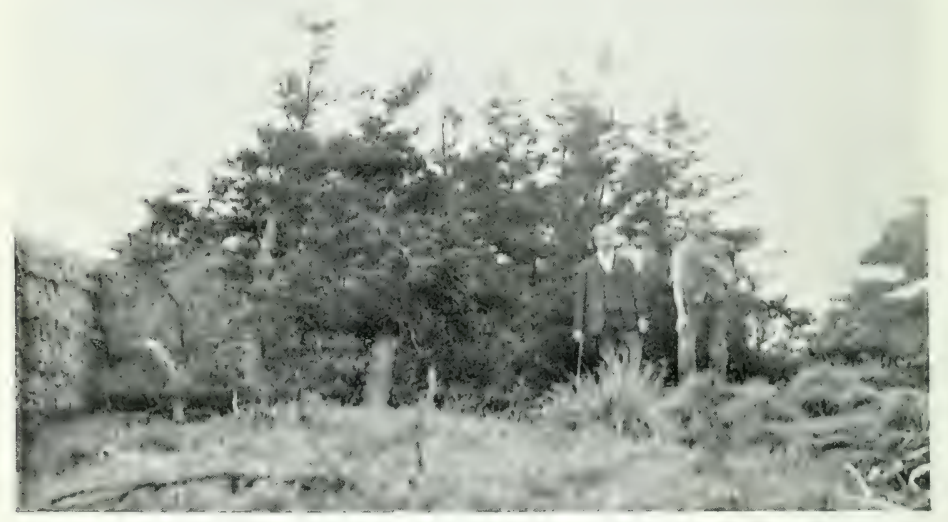

17. Group of White American Spruce on Pennines-2,000 ft. 
April usually resembles March as regards fickleness, but the lengthening day and increase in sun heat bring about a general development of all forest growth. To the nurseryman and planter April is usually a month of anxiety in many ways, but especially with regard to two-year larch, many millions of which may be practically ruined by a night's frost in this month. To the planter, April rain or drought generally decides whether new plantations are to succeed or fail, for unless autumn-planted, a dry April means a trying time to many trees. The proverbial showers with which $A$ pril is usually credited are not always forthcoming, while the temperature ustally remains low throughout the month. Of the two, a cold, backward April is preferable to a warm and early month, for whatever the variations of other seasons may be, it would appear that a certain amount of cold is an invariable ingredient of the three spring months, and premature warmth is always followed by unseasonable cold.

But of all months in the year that of May is probably the most critical of any to the forester and outdoor gardener. The poet has immortalised May as the symbol of hope and resurrection, a month of balmy airs and sunny days, heralding the approach of summer, and the retreat of winter's gloomy skies and chilling winds. About once in eight or ten years, perhaps, the British climate enjoys what may be termed a poetical May, and when this occurs the true lover of nature enjoys a brief taste of Paradise. But the actual, matter-of-fact May is usually something different. In many years, cold casterly and northerly winds prevail, with usually little rain and low night temperatures, which bring about the frost so dreaded by all having to deal with vegetation of any kind. For a day or two at a time more genial winds and a rainy-looking sky promise growing weather, but the

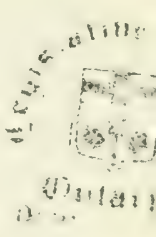


rain frequently passes off after a light fall, the wind returns to its old quarters, and the cultivator's hopes are blighted once more. This type of weather often continues until the middle or end of June, and in such seasons the forester's charges have to run the gamntlet of many insect pests which glory in adding to his discomfiture. To recently planted crops, such seasons work untold havoc, especially on dry gratels or stifl clays, young trees on either being incapable of withstanding drought for any length of time. It is a sad sight to see plants which have pushed out a few dwarf leaves stand practically still for a week or two, and then gradually wither up as the moisture in the ground decreases, and the few roots which they have sent out earlier in the season give up the attempt to extract moisture from the soil, to replace the loss caused by wind and sun aboveground.

Many forest trees, such as larch, ash, and beech, are most easily affected by weather of this kind, the first named being more dependent upon soil moisture than most trees. The effect of May drought upon established trees, however, is seldom so great as that of night frosts, which often exceed 8 or $10 \mathrm{~F}$. on the grass in low-lying places. As regards this feature of May or June, however. the British Isles are probably neither better nor worse than many other parts of Europe, and the ultimate effect of spring frosts, apart from the destruction of flower buds and the loss of the fruit crop, is very slight with most species. Although the young growths of oak, ash, beech, and other trees may be blackened and shrivelled in a single night, a month of genial weather is usually sufficient to obliterate the damage to all intents and purposes, altbough double leaders on the ash may perpetuate the damage to that species. Beech recovers more slowly, while amongst conifers spring frost will cause silver fir to stand still for the remainder of the season, and when 
the damage is repeated year after year, may lead to poor, stunted, and worthless trees. But such damage is dependent largely upon species and situation, and bad as they are, it is difficult to prove that spring frosts alone are responsible for the failure of the majority of trees to grow into good timber.

One serious effect of May frosts is often seen upon newly planted trees which have pushed out a few leaves and then been cut back. In such cases the vitality of the trees is often reduced to such a low ebb that death ensues, and this is especially likely to occur with larch, which is apt to open all its buds at one time, leaving few or none in a dormant state.

The weather of June usually shows a decided increase in temperature, and if sufficient rain falls, the bad effects of May are quickly obliterated. The old saw that 'a dripping June puts all in tune' is usually verified, for temperature is seldom low enough to check the growth of plants, provided sufticient rain, or at least two to four inches, falls. But with a dry June following a dry and cold May things get worse instead of better in many respects. Caterpillars, aphicles, and leaf-eating insects of all kinds injure or reduce the already stunted foliage, and in place of a healthy, dense, and vigorous leaf canopy, thin crowns of perforated and clammy leaves, infested with various pests, are invariably typical of a dry May and June.

Although the actual presence of insect pests is not altogether due to the weather conditions at the time, there is little doubt that their increase, and the bad effects they produce, are aggravated by drought and heat, and with stunted foliage the leaf surface presented to them is much smaller than in a growing year, in which possibly the same number way be present, but spread over a larger area, and therefore less conspicuous and injurious. 
The caterpillars most conspicuous in a dry .June are usually those of the Oak Leaf Roller Moth, and Winter Moth on oak, ash, and other trees, but it is, of course, obvious that their existence is due to the eggs of the preceding summer or autumn, and not to the prevailing weather at the time they appear. In dry Junes, however, the damage done by them is certainly much greater thin the average, and the trees take longer to recover.

After June the remaining summer months usually exhibit one or the other of two weather types-cold and wet, or hot and dry. Occasionally, a combination of heat and thunderstorms may be experienced, such as is usual in continental summers, but more often heat for any length of time is associated with drought, especially in the south of England, where both soil and latitude tend to increase the effect of such weather upon vegetation. In place of heat, however, July and August are more often wet and stormy, and it is in these months that the strong westerly winds, which invariably accompany cyclonic conditions in Great Britain, exert their most injurious influence upon tree growth. For days and weeks at a time in cool summers, moderate gales and strong winds sweep across the British Isles, and although these are seldom strong enough to break branches or uproot trees, their persistent character as reginds direction brings about that leaning and windswept habit which is acquired by all trees growing on exposed sites. These late summer winds, and the comparatively low temperatures they cause, constitute the chief difference between the climate of Britain, and that of the greater part of Western Europe, and provide an explanation of the fact that the height growth of trees in general, and their development on mountain slopes in particular, are very much poorer than what is seen in most parts of Central and Southern Europe. When wind is mentioned in connection with 



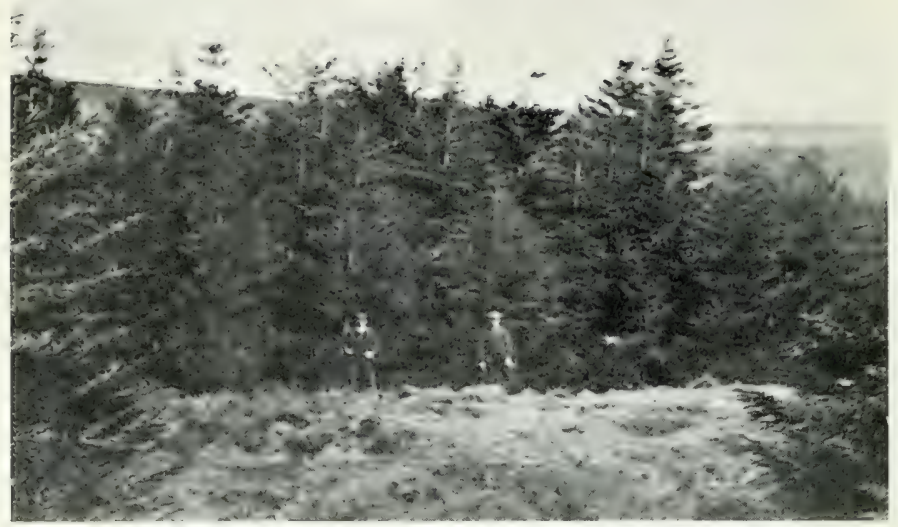

IS. ( GROUP OF NORWAY SPRUCF ON PENNINES-I, TOO FT.

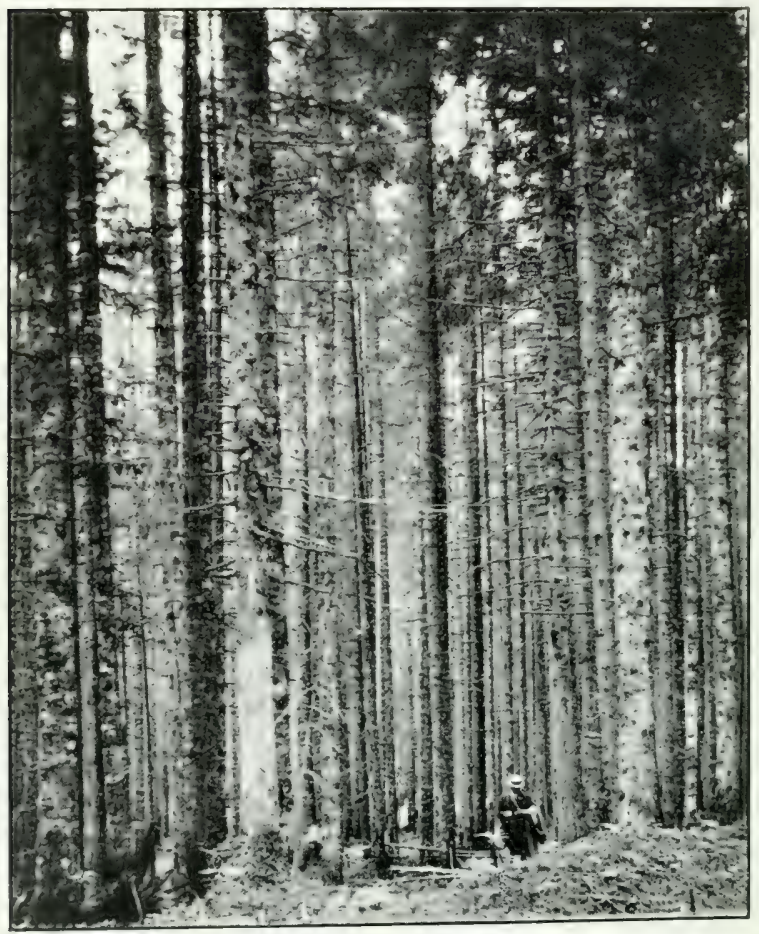

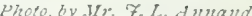

19. SPRUCE RAISED FROM SEED. BAVARIAN ALPS 3, $500 \mathrm{FT}$. 
forest trees, most persons associate the word with those destructive gales which sometimes occur in autumn and winter, and sweep down trees by the acre on thin soils, independently of exposed or sheltered situations. These storms do, of course, immense damage, but they do not interfere with the development of trees from start to finish, as do the more or less annual winds of late summer.

The weather of the remaining months of the year need not be described in detail, as it does not materially affect the development of hardy trees. Species which grow late in the autumn, like larch, Spanish chestnut, etc., may be injured by early frosts, but as a rule the economic forester need not trouble himself about winter weather, except it be gales of exceptional severity, or weather which interferes with his planting operations. Cyclonic gales, however, are not peculiar to Britain, and, taking the average winter, it cannot be said that the conditions are unfavourable to forestry. It may be taken as a fact, however, that the British climate is favourable for profitable timber-growing at comparatively low elevations only, and that above 800 or 1000 feet, according to soil, aspect, and geographical position, timber-growing becomes unprofitable on account of low summer temperatures and strong winds, combined with a more or less thin, cold, and wet soil.

But however far from perfection the British elimate may be, it is only fair to say that a few species thrive in it as well as anywhere in Europe, provided we keep them within 500 or 600 feet of sea-level. These are they which like a cool, moist atmosphere, and are able to make a fair growth and ripen their wood at comparatively low summer temperatures of from $50^{\circ}$ to $60^{\circ} \mathrm{F}$. Larch on suitable soils and situations, silver fir, Scots pine, and ash amongst European trees, can, at low or moderate eleva- 


\section{THE DEVELOPMENT OF BRITISH FORESTRY}

tions, give as good an account of themselves in Britain as anywhere in Europe. Beech and oak, on the other hand, require to be specially favoured as regards soil and situation before they will produce the same bulk per acre, or the same size in individual trees as may be seen in France, Belgium, or Central Germany. It is well known, and the figures given in the table on page 98 confirm it, that the midlands and south of England can produce timber of both these species second to none in size and quality, but it is usually produced on first-class soil, and under arboricultural conditions which have favoured the quick production of timber in early youth. In thick, crowded woods, resembling those of continental forests, the arerage height growth of most species in Britain falls below that found abroad, although not perhaps to a marked degree, if elevation is ignored altogether. For instance, crops grown between 1000 and 2000 feet in Hanover or Belgium are little if at all inferior to those grown between 500 and 1000 feet in the midlands of England or the southern parts of Wales and Ireland. But while timber of fair size can be produced at 2000 feet in the former countries, it is scarcely possible to produce more than bushes or scrub at that elevation anywhere in Britain. The highest point at which we have personally seen trees grown in Britain is 2000 feet in the Pennine Chain, and these were white American spruce, about 10 feet in height, the hardiest species in existence. In the same wood (Ashgill), timber of commercial value ceased at about 1500 feet, although occasional trees might be found higher. In the Grampians instances of larch growing successfully up to 1500 feet or higher may also be seen. Most observers of tree growth in Britain agree that an average elevation of 1000 feet is as high as commercial timber can be produced. Larch and spruce, on sheltered aspects and comparatively good soil, will attain a height 
of 50 feet or so, up to 1500 feet, but, on the other hand, thin soils and exposed aspects cease to produce timber at 700 or 800 feet, and the nearer the western coast-line is approached the more this statement holds good. On average soil it may be said, in a general way, that the production of commercial timber of such trees as larch, spruce, and Scots pine ceases on western aspects at elevations of 300 feet within twenty miles of the west coastline of Ireland and Scotland. Silver fir, Corsican pine, etc., may succed somewhat higher, but neither of these species is much affected by wind. Farther east, and on sheltered aspects, these elevations may be increased by 200 or 300 feet in each case, and possibly more when larch and spruce are alone considered, as these species usually fail at high elevations in Britain more on account of wind than lack of warmth during the growing season. Fifty miles from the western coast-line a further increase in elevation way be accompanied by fairly good timber production, until, as already stuted, it ceases at about 800 feet on exposed, and 1200 feet on sheltered aspects.

In the Harz MLountains, lying within the same degrees of latitude as Wiltshire and Dorsetshire, spruce produces crops of timber at 2000 feet, containing 8000 to 10,000 feet per acre, and reaching a height of 95 to 100 feet. In the Thuringerwald, in slightly lower latitudes, similar crops are obtained. In the Belgian Ardennes second-class localities for spruce, silver fir, etc, are found at 2000 feet. In the Black Forest, Bavarian Alps, Bomherwald, etc., useful timber can be grown at 3000 to 4000 feet, elevations which, of course, do not occur in Great Britain to any extent. Going farther north the mountains of Norway produce timber, of Scots pine and spruce, up to 1500 or 2000 feet, owing to the hotter summers and greater length of the days during the months of June and July. The absolute limits of tree growth in the Harz 
are given by Endres as 4000 feet for beech, and 1000 feet for oak, ash, and elm. In the Riesen-Gebirge spruce reaches 5000 feet, and similar examples of timber crops at high elevations may be found elsewhere. In a general way, it would appear that the absolute tree limit is from 1000 to 1500 feet higher than the timber limit.

Whether the climate of Britain would allow better results to be obtained with improved conditions of soil and situation cannot be said with certainty. No doubt, higher mountain ranges would provide better soils and more sheltered aspects than are now found to a limited extent between 1000 and 2000 feet in the north of England, Wales, Scotland, and Ireland. It is conceivable, for instance, that the Highlands of Scotland would give a much higher proportion of plantable land if they lay within the same latitudes as the south of England, but these are suppositions which cannot be put to the test, and taking things as they are it is no exaggeration to state that the line of profitable planting on British hill ranges lies from 500 to 1000 feet lower than is the case in Belgium and Hanover, and from 1000 to 3000 feet or more lower as one goes farther south in British latitudes. How much of this is due to elevation, how much to soil, and how much to prevailing wind, it is difficult to say.

Any records of temperature and wind at high altitudes in Britain are too few to show clearly the climate of hill ranges, but those which exist indicate that the temperatures above 1000 to 1200 feet are below the minimum for commercial timber production, except in the south of England and Ireland, as shown in the table on page 94.

In connection with the subject of climate, the acclimatisation and adaptation to environment of forest trees come largely into play. All species have certain limits of temperature, above or below which they do not grow, or cannot survive the first winter. Somewhere about midway between these upper and lower limits may be 


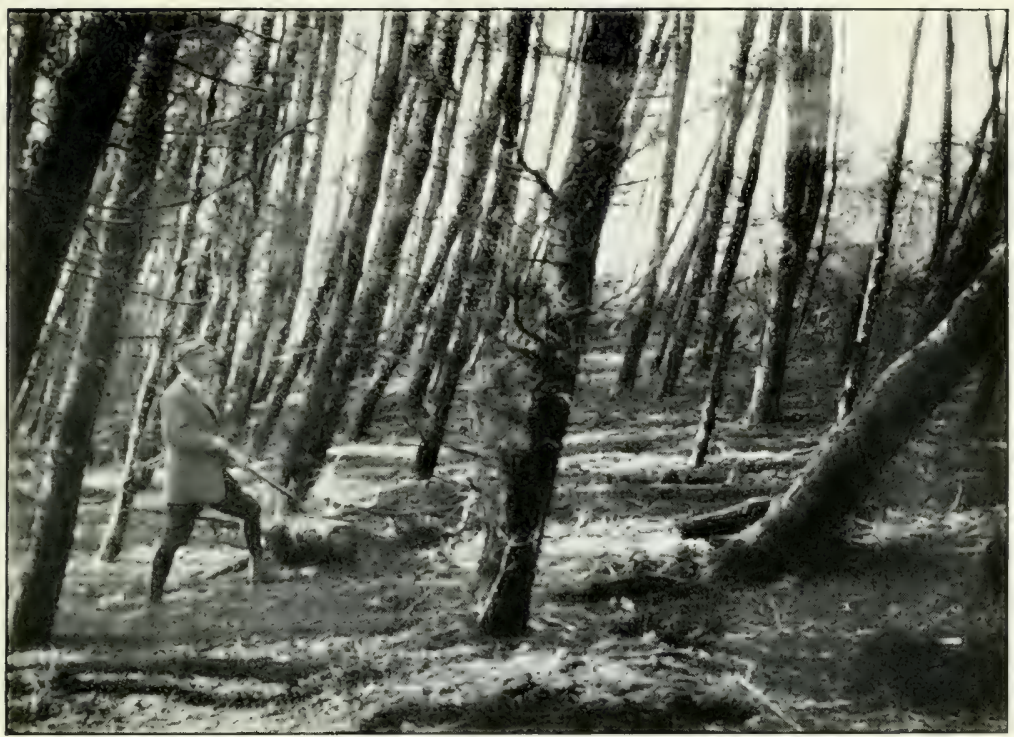

20. LARCH ON EXPOSED GROUND-9OO FT.

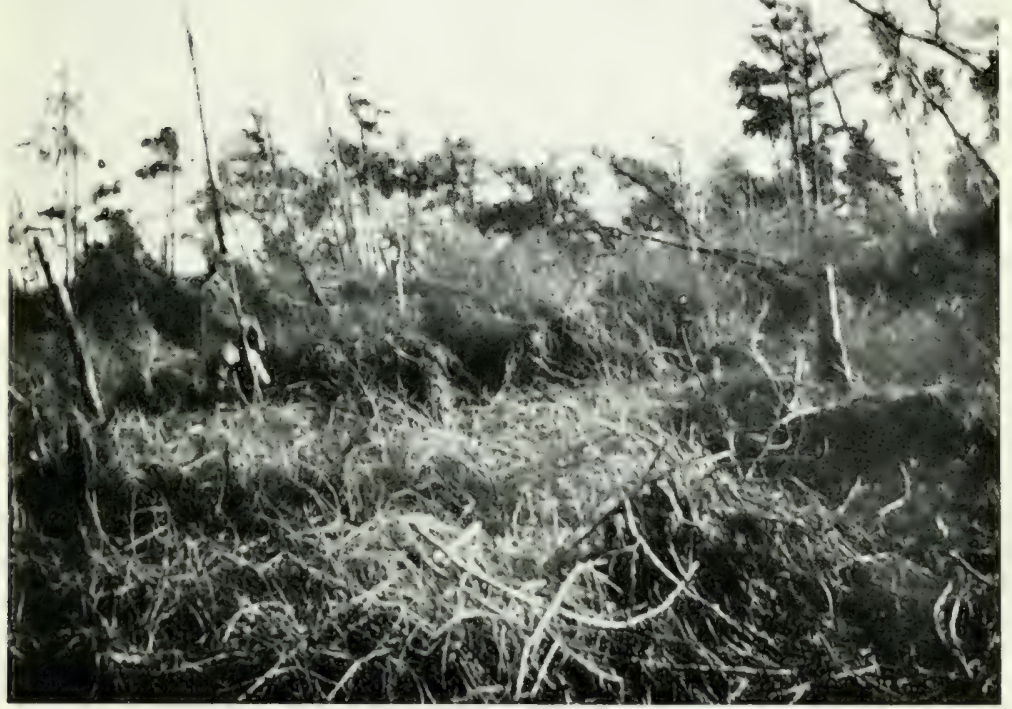

2I. EFFECT OF CYCLONIC STORY OS YOUVG CONIFEROUS WOOU. 

found the vegetative and reproductive optima, representing temperatures most favourable for growth of wood in the one case, and for reproductive organs and seed production in the other. Apart from exceptional cases, it may be stated that any plant can be grown if the climate does not exceed those limits, and it matters little, so far as the existence of the individual plant is concerned, how far from the optimum this limit may be. For normal development of stem and fruit, however, any considerable deviation from optimum temperatures is injurious. If too cold, badly ripened wood and immature seed are the results. If too warm, damage from drought and a tendency to produce excessive but abortive seed at the expense of stem growth are common features. Spanish chestnuts, for instance, can be grown to a fair size in the north of England or Ireland, but seldom ripen their fruit. Larch grows in all parts of Britain, but in the south of England it rarely attains a large size on dry soils, while it produces seed at a very early age. Numerous other instances might be quoted which are more or less familiar to most foresters. In addition to the specific climatic range, however, the individual range must be recognised which enables certain individuals of any species to exist or succeed above or below the average limits of the species. Those who observe the effect of severe winters, of late or early frost, summer drought, etc., see that certain plants in a crop of any species are more resistant than others to extremes of one kind or the other. This may be due in some cases to a retardation or acceleration of certain stages of growth, such as late leafing, early ripening, or to increase or decrease of vigour; or in others to the inherent capacity of the plant to resist exceptionally high or low temperatures in or out of the growing season. All or any of these characters may enable one plant to escape from injury which the species generally may suffer from. 


\section{THE DEVELOPMENT OF BRITISH FORESTRY}

Probably what is generally known as 'acclimatisation' is mixed up with this individuality. When a new species is introduced by seed, the number of plants which survive is usually in proportion to the resemblance which the climate of the new habitat exhibits to that of the home of the species. Sub-tropical plants generally would be killed out in an average winter in Britain, the climate of the latter being below their vegetative range. Eucalyptus, Pinus insignis, Cupressus macrocarpa, etc., survive the average winter in the south of England and Ireland, but are killed of by average cold in Scotland, and the north of England. Here and there, however, one comes across occasional specimens which, owing to favourable sites or unusual hardihood, are able to live until the arrival of one of those severe winters which indicate the clinatic extremes peculiar to the latitude. For many years Pinus maritima was grown in Denmark, but a temperature of minus $10^{\circ} \mathrm{F}$. in or about 1860 killed them off. In 1879-18s0 large numbers of deodars, hollies, etc., were killed in Scotland. No doubt the absolute degree of cold which can be borne by any species depends greatly upon the condition of the shoots as regards ripening, and Table III. is interesting in this connection. These instances point to the fact that no species can be acclimatised outside its thermal limit, whether of heat or cold, and that the word can only be properly applied to a new type or strain of plant which has been raised from the seed of the hardier specimens, or individuals which have withstood the severest winter peculiar to the climate. A possible field for experiment may lie in this work, as suggested recently by Dr. Augustine Henry before the Iinnæan Society, but a public department or institution could alone carry it out successfully.

The absence of true acclimatisation is seen in most species which have been growing sufficiently long in this 
country to exhibit evidence of it if it existed. Larch produces seed freely in the British Isles, and plantations of various sizes may be seen descended from seed ripened in the country. Yet these trees burst their buds in March or April long before the temperature is sufficiently high for growth to proceed; whereas native trees either remain quiescent until May, as oak, ash, beech, Scots pine, etc., or are capable of withstanding the frost of March and April with impunity, as alder, willow, poplar, birch, hawthorn, etc. Horse chestnut, Norway maple, lime, sycamore, and other early leafers, are sufficiently hardy, howerer, to withstand most spring frosts without serious injury, but suggesting, if not indicating, an acquaintance with quicker and more decided spring temperatures than they find in Britain. Instances of late growth in autumn occur with such species as Robinia, Zelkowa, Spanish chestnut, etc., causing badly ripened shoots, and subsequent injuries from early frost, and these habits do not appear to be altered by long-continued growth in this climate, although the older a tree becomes the less the tendency to start or continue growth early or late.

Another feature of plant life is the power of adaptation to a new environment, enabling the plant to make certain provisions against the risk incidental to heredity and peculiar to an ancestral type. With successive generations this process is progressive. The leafing of trees before the arrival of normal growing temperatures, or their growth after the approach of winter, may be regarded as hereditary characters. The winter flowering of trees, as hazel, birch, willow, poplar, ash, elm, alder, etc., is also hereditary, and cannot be elminated within limited periods of time. Morphological or physiological adaptations, such as the production of hairs, thickening of epidermis or cuticle, production of midsummer shoots on onk, beech, etc., reddening of needles during the winter months, 


\section{THE DEVELOPMENT OF BRITISH FORESTRY}

formation of new learlers after continuous injury from frost, suckering, etc., may be considered as acquired by the species to meet certain contingencies, and may be brought about more quickly, but in any case must occupy centuries of time, and be spread over numerous generations.

It is doubtful if any species introduced within the last two or three hundred years shows any definite signs of having acquired such characters. The individual climatic range may more often exceed the specific in some species than in other's, as is evident from the fact that certain species from warm climates may survive our winters in large numbers, while others fitil altogether. This is probably due to the overlapping of species from colder and warmer climates which is common in all floras. The birch and willow grow as far north as the Arctic Circle. The Spanish chestnut and walnut are indigenous to Southern Europe, but all are capable of meeting on common ground in Central Europe as indigenous trees. Scots pine represents another type of a tree which appears to be practically ubiquitous from the Ilediterranean to the Aretic Ocean. Differences are also due to the winter and summer climatic ranges, the former determining the lowest temperatures the species is called upon to endure, the latter the heat it requires or receives for its normal vegetative or reproductive development.

While the temperatures of the British climate never fall below the winter minimum of any European species, they do not reach the summer minimum, so fir as normal development is concerned, of several, such as the Cork oak, walnut, Spanish chestnut, etc. In the south of England the two last-named succeed fairly well, but in the other parts of these Isles favourable soils and situations are necessary to bring them to any size. In a general way, therefore, it may be assumed that the only 



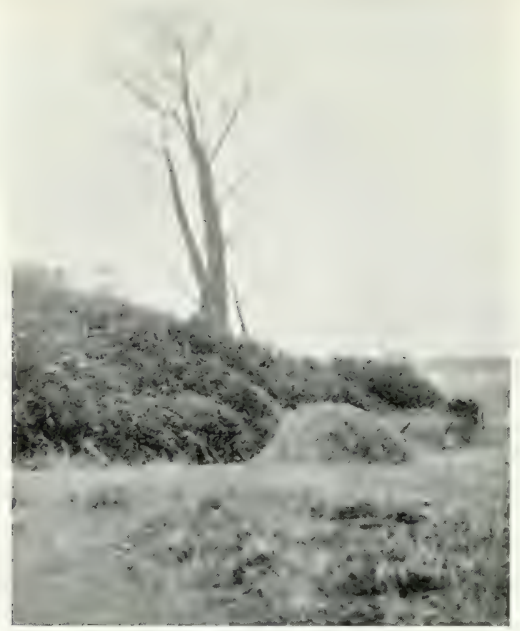

24. MARITIMe PriNe AMIONgSt Naturar. SCRUB. WEST COAST OF IREIANI).

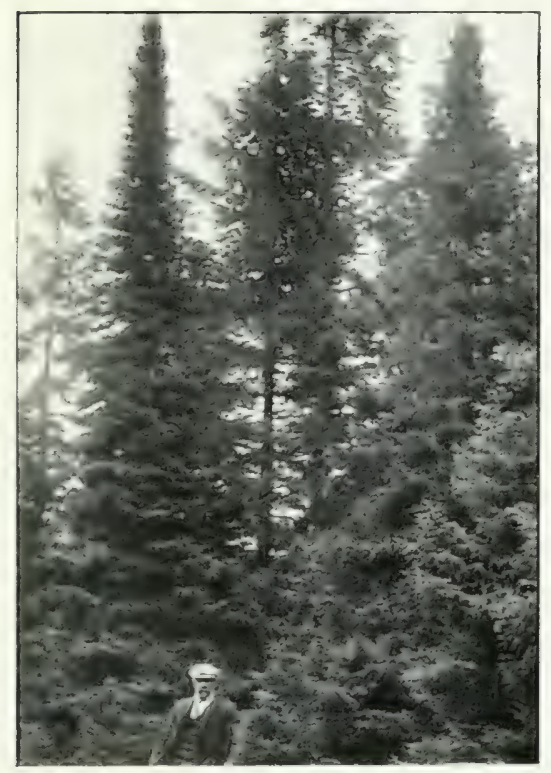

22. White A.MericaN Sl'kUCE AT I, 500 FT. P'EXYINES.

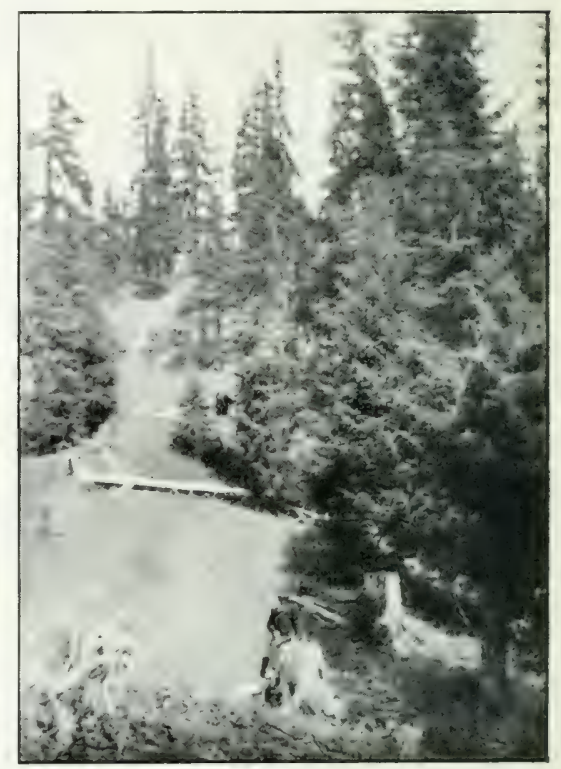

23. Grazen Spruce forest. BAVARIAN ALPS-5,00OFT. 
approach to true acclimatisation lies in the field of successive breeding or reproduction from selected types, a process which requires long periods to carry out, and an expenditure of time, care, and study outside the scope of ordinary commercial enterprise, taking the uncertain and problematical results into consideration. The simple method of hardening off tender species, by planting under partial shade and gradually reducing the latter as trees get above the spring or autumn frost line, may possibly be regarded as a form of acclimatisation. But while this may preserve a species which would otherwise perish during the first few years of its existence, it does not enable the species to develop to its normal size in a climate inferior to that of its native habitat, and from an economic point of view this hardening off is of little value.

This statement does not, of course, apply to the regeneration of such species as ash, beech, or silver fir under shelter wood, as this may be considered the normal method followed under natural conditions, and in primeval woods frost damage is less likely to occur than with crops artificially planted on bare or clear ground. Ground frosts in May of more than $10^{\circ}$ or $12^{\circ} \mathrm{F}$., although of almost annual occurrence, must be considered abnormal features of the British climate, just as January temperatures of $50^{\circ} \mathrm{F}$. or more are abnormal. Owing to the presence of latent and late developing buds these frosts are seldom if ever fatal, and on good soils and situations trees may completely recover from them in the course of a month or two, and in any case they do not affect the ultimate vegetative development of a species. The fact that silver fir, beech, Spanish chestnut, oak, and other species sensitive to late frosts may be found of great size and height in deep valleys and hollows is a certain proof that late frost alone will not hinder or permanently check the development of a species, although it certainly checks 
its growth during the first fifteen or twenty years, or until the leading shoots have reached a higher level than that attained by freezing temperatures in ordinary springs.

\section{T A B L E I I I}

Extremes of Cold borne by various Exotic Trees without INJURY IN THE WINTER OF 1892-1893, as recorded by the late Dr. Bernard Danckelmann. in Germany.

Uninjured by $-35^{\circ} \mathrm{F}$.

Abies balsamea.

Abies Nordmanniana.

Picea sitchensis.

Picea pungens.

Pseudotsuga Douglasii.

Larix leptolepis.

Cupressus Lawsoniana

Cupressus nutkaensis.

Pinus Banksiana.

Pinus strobus.

Betula lenta.

Juglans nigra.

Acer dasycarpum.

Acer negundo.

Acer saccharinum.

Fraxinus americana.

Quercus rubra.

Prunus serotina.

Injured or killed by temperatures below $-30^{\circ} \mathrm{F}$.

Juniperus communis.

Juniperus virginiana.
Pinus rigida.

Thuia gigantea.

$$
\begin{gathered}
\text { Injured or killed by }-23^{\circ} \\
\text { to }-30^{\circ} \mathrm{F} \text {. }
\end{gathered}
$$

Abies pinsapo.

Cryptomeria japonica.

Picea polita.

Wellingtonia gigantea.

Zelkowa Keaki.

Prunus avium.

Injured by $-14^{\circ}$ to $-22^{\circ} \mathrm{F}$.

Pinus laricio.

Pinus ponderosa.

Catalpa speciosa.

Injured by $-6^{\circ}$ to $-13^{\circ} \mathrm{F}$.

Pinus densiflora.

Pinus pinaster.

Pinus Thunbergii.

Ilex aquifolium.

Juglans regia.

\footnotetext{
1 Zeitschrift für Forst- und-Jagdwesen. August 1894.
} 


\section{T A B L E I I I-continued}

Exotic ANd other Trees Killed and Injured in SCOTLANd IN Winter 1879-1880, as recorded by the late Dr. Hutchison of Carlowrie. ${ }^{1}$

Temperatures varying from Zero to $-16^{\circ} \mathrm{F}$.

Trees killed by $-4^{\circ}$ to $-16^{\circ} \mathrm{F}$.

Cedrus deodara.

Picea sitchensis

Picea polita.

Libocedrus decurrens.

Acer negundo.

Cryptomeria japonica.

Salisburia adiantifolia.

Araucaria imbricata.

Juglans regia.

\section{Trees injured}

Wellingtonia gigantea.

Abies pinsapo.

Robinia pseudacacia.

Castanea vesca.

Cupressus Lawsoniana reported killed in Kelso district, but otherwise uninjured.

1 Iransactions of Highland and Agricultural Society, vol. xiv. 


\section{CHAPTER V}

SOIL AND SURFACE CONDITIONS IN THE BRITISH ISLES

THe term 'soil' may be interpreted in so many different ways that it is scarcely safe to use the word in connection with forestry without stating clearly what is meant by it. To the agriculturist or gardener soil is usually looked upon as a mixture of vegetable and mineral matter containing all the elements necessary for the support of plant life in a readily available form, and imbedded in a matrix which admits of easy ploughing, digging, or harrowing. For the latter operations to be performed economically the soil must chiefly consist of fine particles, which when dry are usually designated dust, when wet, mud. Rocks, boulders, and stones, too large to be turned over with the spade or plough, must be absent from the first foot or so from the surface, but below that depth the farmer or gardener is not directly, although probably indirectly, affected, according to climate and other circumstances. Impervious rock or clay, for instance, a few inches below the surface, affects the farmer and gardener by reason of the rapidity with which the soils become waterlogged in wet, and parched or baked in dry weather; otherwise the subsoil is of little consequence.

To the grower of timber, however, soil must be considered in a different light. To the planter the actual surface conditions are important only so far as they facilitate or obstruct the process of planting, and rocks or coarse stones usually increase the work of planting, according to the size or species which have to be used; otherwise the surface alone is unimportant as compared with the general 


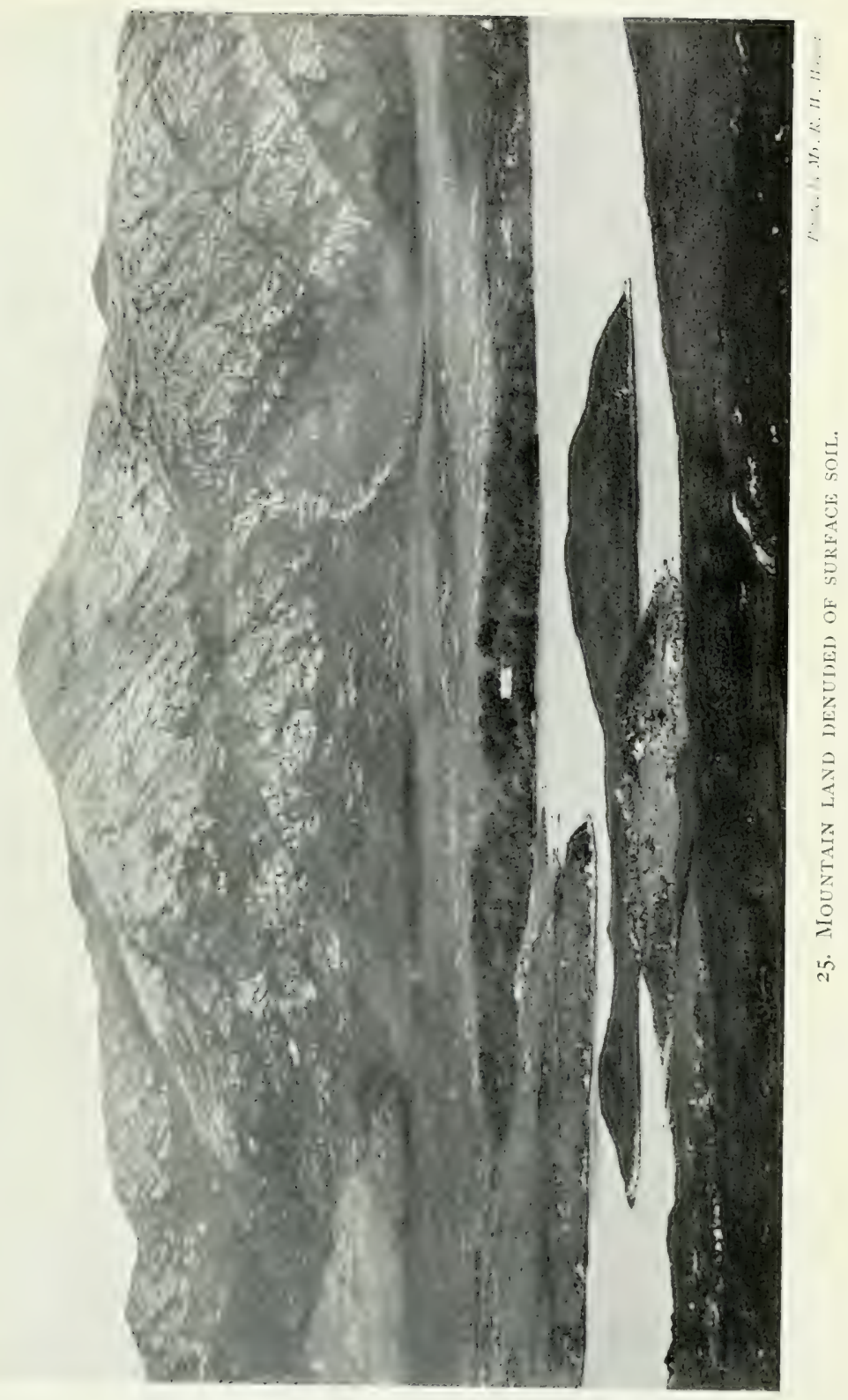



average condition of the first three or four feet downwards. For tree growth to be profitable, this depth of soil, subsoil, surface stratum, or whatever one likes to call it, must be porous, and capable of being easily penetrated by the roots of trees, and also contain a sufficient quantity of moisture in which nutrient salts are in solution to supply the needs of trees at all seasons. Subsoils almost impervious to air and water, whether solid rock or stiff adhesive clays, are not suitable for many species, although much depends upon the climate. Spruce and larch sometimes do well on a foot or so of soil resting on rock or clay; but in the former case the summer rainfall must be frequent and heavy, or in the latter a comparatively steep slope must exist to carry off' water which would otherwise stagnate. It is seldom that big timber can be found on either of these classes, although the clay soil may be more valuable for pasture than many soils on which timber does well. Similarly, very fine sand, owing to lack of aeration, is not favourable for many species, except, perhaps, for oak, chestnut, ete., and even larch rarely produces sound timber upon it. Coarse rubble, again, which allows rain to pass through like a sieve, will not support tree growth, although it will sometimes be found in the form of 'talus' or 'detritus' with loam, clay, or' gravel within a foot or two from the surface, in which case the trees, of course, grow on the lower stratum. Very coarse gravel in a dry climate is not suitable for the same reason, and many other instances might be given of thin soils resting on very open or porous subsoils which fail to give satisfactory results through lack of moisture during dry weather.

But whatever mechanical condition the soil or subsoil may be in, the finer particles which compose the soil of agricultural or garden land must also be present in some form or other, although they need not necessarily be in the form of a solid layer of surface. In all timber-growing 
soils it is invariably found that fine soil, either as a thin coating between layers of rock, or in the filling up of the spaces between the larger particles, is always present, and the greater the proportion this soil bears to the unweathered and harder rocks and stones, the better trees grow. While, therefore, the surface layer of ordinary soil is not necessary for trees, fine soil particles must be present within reach of their roots at all times, and in such a condition of fertility as to allow growth to proceed at a normal rate.

The most favourable timber-producing soils in a general way, and apart from those required for particular species, are deep gravelly loams, porous enough to prevent stagnation, and yet containing enough clay in their composition to keep them fresh and moist during seasons of drought. In wet climates little difference probably exists between such soils and those resting on a bed of well broken-up rock which allows the roots to penetrate easily between the fissures. Slates, schists, and thinly bedded sandstones and limestones all produce good timber of most conifers, beech, etc., in the western counties of England, Wales, Scotland, and Ireland, or wherever a summer rainfall of ten to fifteen inches is general. Limestones are possibly more favourable than sandstones to ash and beech, but few other species do so well on them, given equal situations, and depth of surface soils in each case, as on other formations. Lime in the soil equal to more than 1 to 2 per cent. of calcium oxide appears to be injurious to Donglas fir and one or two other species. Probably limestone formations represent the only geological type, the chemical nature of which exercises any influence upon tree growth. On all other formations depth, porosity, and moisture appear chiefly to determine the productive capacity of the soil, assuming, of course, that the latter contains the various elements necessary for maintaining plant growth. 
No greater fallacy was ever propounded than the theory that forest trees can dispense with soil fertility. It is, of course, quite true that surfices will produce fine timber which cannot yield a profitable agricultural crop. The latter maty fail merely from sterility in the first few inches, or, as is more often the case, through the rough, uneven, or stony character of the surface preventing cultivation or close grazing. But the fertility existing in the soil within three or four feet of the surface, in the form of phosphates, nitrates, potash, and water-holding capacity, will, if carefully examined, be found somewhat on a par with that of ordinary agricultural or grazing land. The great difference between forest trees and agricultural crops lies in the fact that the former have a wider and deeper root range, while trees can be established without that complete cultivation of the surface which is necessary for the latter. Under a forest canopy, again, moisture is preserved near the surface, the physical condition of the soil is improved, and the finer soil particles are not washed away, or soluble nutritive material washed out so readily. These differences in rooting, and requisite surface conditions between forest and agricultural crops account in a large measure for the apparent, rather than actual, power which forest trees possess of growing under comparatively sterile soil conditions. Grow seedlings on sterilised soil, or young trees successively in poor, unmanured ground, and the results are little better than would be the case with ordinary farm or garden crops. Agricultural chemists have shown that the quantities of ash constituents removed by a crop of commercial timber are far less than those removed in crops of oats, barley, or wheat calculated per ton of raw material in each case. But the fact appears to be overlooked that the soil under the latter crops is artificially stimulated, or encouraged by cultivation and manuring to yield up its soluble food- 
forming materials, which is not the case with land under trees. To make a proper comparison between the drain on the soil in either case the analysis should be confined to the annual growth of the same or analogous plant structures of crops grown under similar conditions, such as the straw or haulm of agricultural crops, and the timber of forest crops on manured and cultivated ground. If oats or barley were dibbled into ground covered with weeds or rubbish, the ash constituents of the resulting crops would probably be as small, weight for weight of dry substance, as those of forest trees. The fact, again, appears to have been overlooked that the comparison is being made between a crop using the most fertile portion of the surface soil, and another partly obtaining its nourishment from imperfectly weathered subsoils.

It is a well-known fact that cultivation, in the form of trenching to a depth of two or three feet, stimulates the grow th of forest trees for the first few years enormously, but that this increased rate of growth is not maintained beyond a certain period. On two soils of equal quality it is probable that trees will attain the same size ultimately whether the ground at the time of planting is trenched or not. 'The Rothamstead experiments have shown that the fertility of the soil cannot be reduced beyond a certain point under cereals, and it is equally probable that a permanent increase in fertility cannot be produced by forest crops. It is more probable that the improvement in growth noticed in trees following previous crops is due to the physical change which has taken place by the accumulation of humus on the surface, and the lilling out of surface growth, rather than to any increase of natural fertility, other than that due to the temporary nitrogen supply from the humus. Soil improvement in this way has its limits, and there is probably no good reason for the assumption that afforestation can do more than 



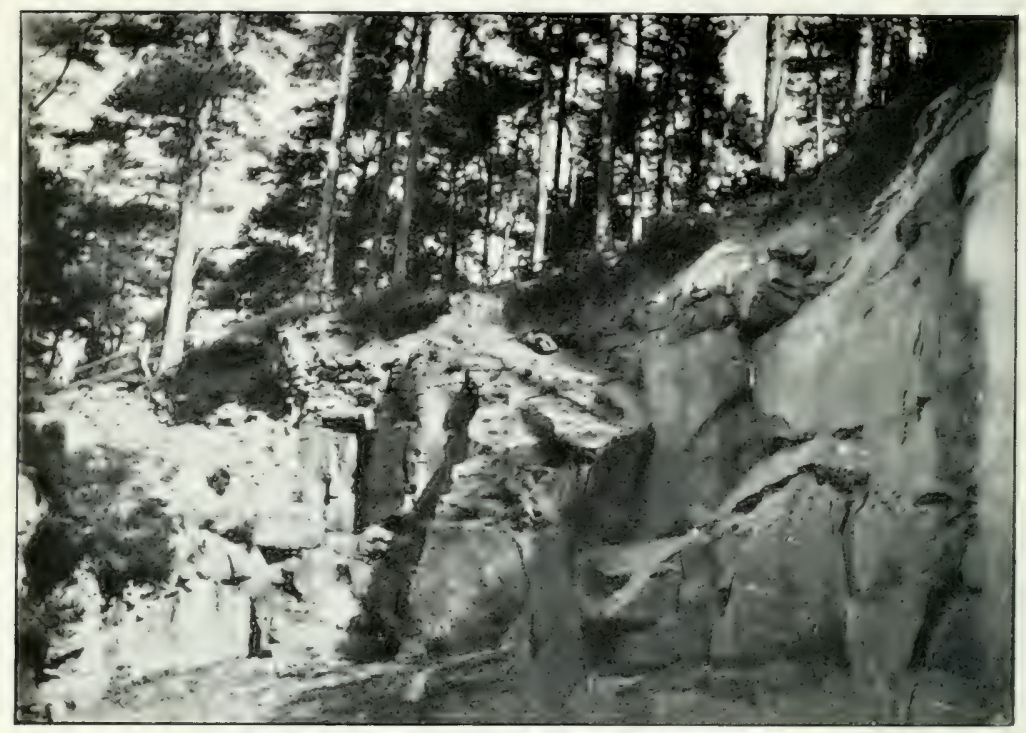

26. Section of Milistonf Grit, Serface carkying goon Scots Pixk.

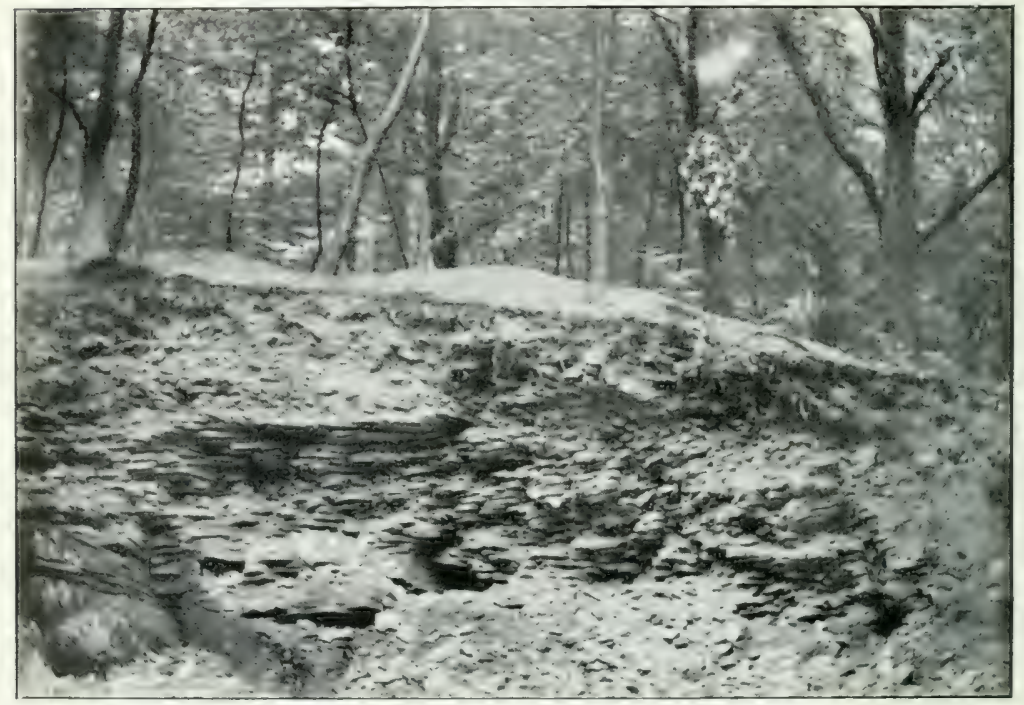

27. GRATEL SUBSOIL PROIUCIX̃(; (MOOI) TIMBER. 
increase the fertility of a poor soil by a very small, and in many cases inappreciable, extent. The differences in the growth of timber due to variations of soil and situation are as distinctly marked in natural forests, thousands of years of age, as in newly planted ground, although in the former this difference may be relatively reduced by mutual shelter, and improvement of the local climate, and these are probably the greatest factors.

Take, for instance, two lots of trees of the same species, one planted on poor land recently cleared of timber, such as larch or beech, and the other on good fertile soil which has been under grass for perhaps a century. For the first two or three years, the trees on the poor soil will probably make a better growth than those on the grass, owing to the more favourable conditions of the first few inches of surface, and the greater fertility due to the decay of the humus left by the old crop. But when once the trees are thoroughly establisher, and the roots in each case have penetrated to a depth of a foot or so, the better soil will quickly show its influence on the growth of the trees, and the difference becomes more marked as time goes on. If the trees on the poor soil are sheltered by old crops from prevailing winds, while the others are fully exposed to then, the difference may be less marked; but given similar altitude, exposure, etc., the natural fertility of the soil will make itself felt in a comparatively short time, according to the species and general climatic features of the locality.

The successful growth of trees at high elevations in Central Europe is closely connected with the superiority of the soil over that found in the British Isles generally above the 1000) or 1500 feet contour line. Bare rock, or thin, poor soils may be as abundantly represented in the one case as the other, but in the British Isles certain types occur at a much lower level, and consequently the 
production of timber is limited accordingly, apart altogether from climatic conditions.

In the west of Ireland and parts of Scotland large areas of surface occur at 200 to 300 feet above sea-level, counterparts of which would scarcely be found under 3000 or 4000 feet in Southern Europe. The relative proportion of non-productive timber-land to total surface in the mountain range of European countries increases with the latitude, and while the effect of elevation is seen for every 100 feet or so above 500 feet in Great Britain, little definite effect can be noticed over the greater part of the Continent until altitudes of 2000 or 3000 feet have been reached.

Soil changes due to climatic influences, of course, go on in all countries. Ramann, writing of the soils of North Germany, describes these changes in the following words ${ }^{1}:-$

There are in Europe three plant formations constantly in opposition-the peat against the forests of the north, the heath against the broad-leaved forest, and the latter against the steppes. The soils of North and part of Niddle Europe are geologically young, and a comparatively short time ago other vegetative forms predominated than those found to-day. These soils are glacial and steppe soils left from diluvial and post-diluvial times. The weathering of glacial soils is far advanced only on the poor sands, and even here not universally. We find the diluvial sands of the North German plain free of uncombined lime for considerable depths, the original lime having been washed out, but the weathering of the silicates has seldom proceeded deeper than ten inches. The leaching out is slow, and the predominating vegetation assists the soil in checking it. The annual leaf-fall returns mineral constituents to the surface which have been ab-

1 Bodenkunde. 


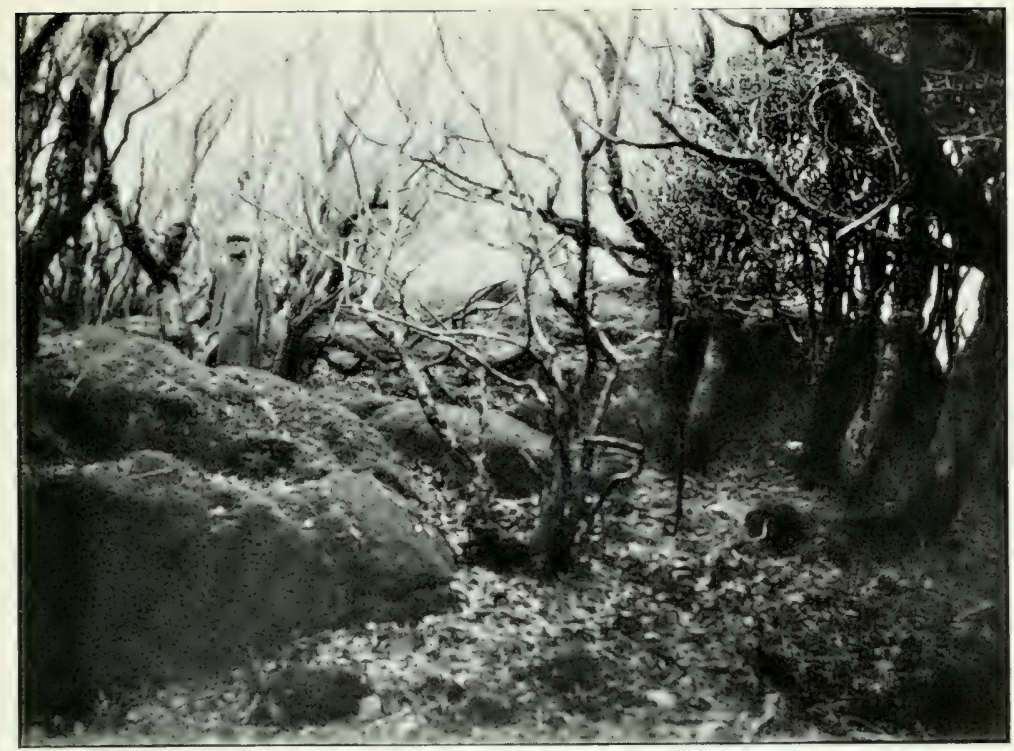

28. BOULDER-STREWN SURFACE CARRYING NATURAL SCKUB

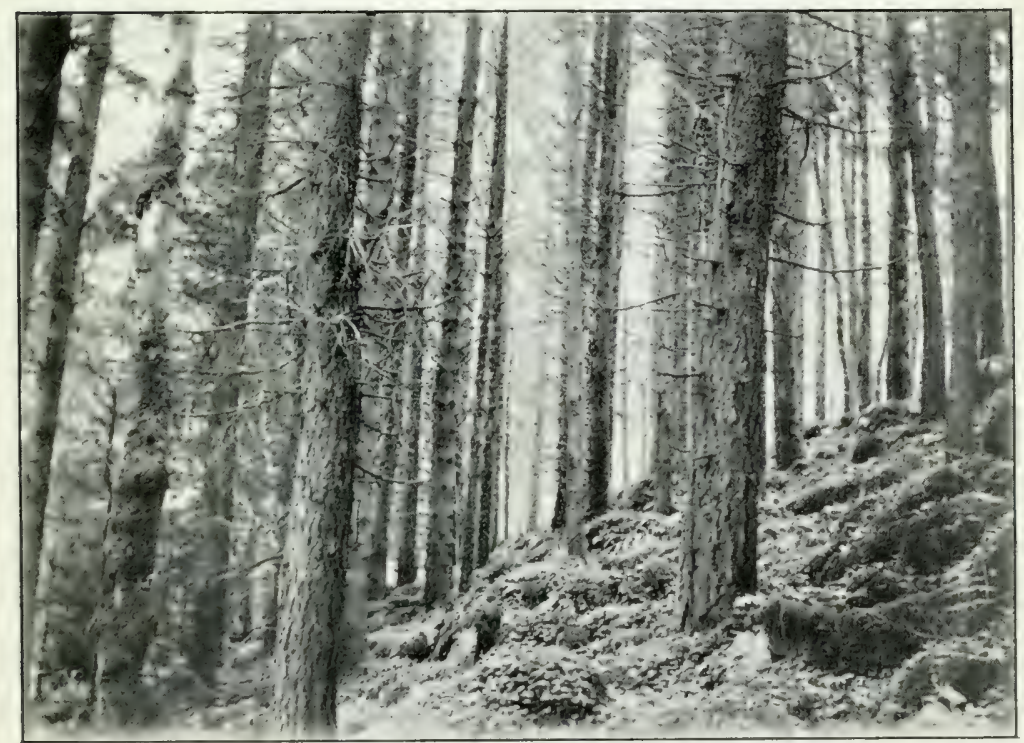

29. IARCH AXI) SPRUCE ON BOULDER-STREWN SIOPE. 

stracted from deeper layers by the roots. By these means the washing out of the soil is resisted, but not altogether prevented, as with every drop of water which filters through into the subsoil, fertilising materials are abstracted from the surface.

'It is, therefore, not surprising that the soil is finally impoverished. Many foresters believe that deterioration of the forests on diluvial soils has taken place, and probably with good reason. For hundreds and even thousands of years the strife may be maintained against the deteriorating factors, but they finally prevail, and more easily when assisted by other circumstances. In this way the heath has expanded at the expense of the broadleaved forests, and the soil changes that have perhaps been impending for thousands of years occur in a few hundreds, or in many cases in half a century. The fundamental error of the view generally prevailing to-day is that man alone, or almost entirely alone, has brought about the present distribution of vegetation in the older cultivated lands, and that nothing more is required to restore the earlier and better conditions than to give Nature her way again. Man can retard or hasten natural processes, he can maintain his cultivated lands by artificial methods, but his constant activity does not prevail against the great march of Nature. The heath, for instance, is a natural plant formation which would not have been formed had not radical changes taken place in the soil. Earlier or later, again, without the agency of man, the peat or heath pushes back the forest.

' The suppression of the forest by peat proceeds most rapidly. Alterations in the surface, which consist essentially of accumulations of humus, proceed rapidly as compared with changes in the mineral soil, and opportunities for the origin and formation of peat are numerous. In addition, the growth and extension of 
the peat are favoured by the saturation of the ground along its edges.'

There is little doubt that the process described above has been going on in Britain, and the result is seen in the heaths of the south and east of England, the mountain peat of the hill ranges, and the bogs of Scotland and Ireland. Whether the climate has materially altered since the trees whose remains are still found under peat at 2000 to 2500 feet above sea-level were growing or not is a matter of opinion, but from records of temperature at high elevations given elsewhere, it is evident that the climatic conditions are all that are required to farour the growth of peat at the present day, wherever soil conditions, such as impervious subsoil, or the absence of allialine bases, bring about stagnation and acidity. Under a crop of trees the shading of the ground would lower the temperature of the surface soil sufficiently to retard the rapid decomposition of humus produced from the leaffall, while the evaporation of surface moisture would be checked, and the soil maintained in a more or less saturated condition from the heavy annual rainfall of forty to sixty inches, which is more or less general at high elevations. Under the shade of trees it is said that the summer temperatures at a depth of two feet are lower by $2^{\circ}$ to $5^{\circ} \mathrm{F}$. as compared with those in the open field, while in winter they are slightly higher in the forest than outside it.

While these conditions are gradually brought about, and the accumulation of peat above the tree limit proceeds, the constant soakage of acidulated water down the hillsides would gradually result in the death and decay of the upper belt of trees, which were already growing on a surface buried under a layer of raw humus. This process can be seen going on in highlying plantations to-day, and can only be checked by 



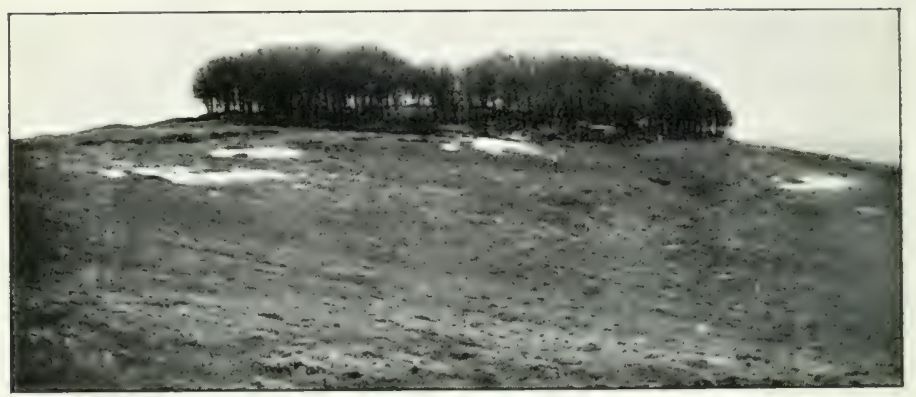

3(). BEECH CLUMP ON SITE OF CHALK PIT. WIITSHIRE DOWNS.

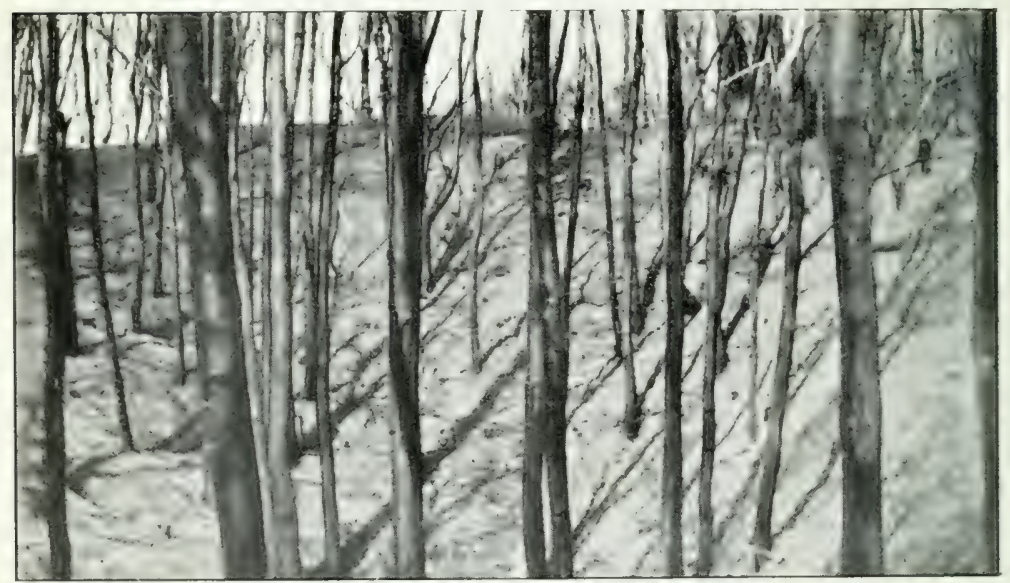

31. VIEW IXSIDE CLUMY SHEWN IN Fi( 30. 
artificial drainage, until the line is reached at which higher temperatures, and a reduced rainfall bring about the decomposition of raw humus at the normal rate. Peat is never formed on porous soils at low elevations, except in the extreme west of Ireland or Scotland. The low-lying peat bogs of the ordinary kind found in Ireland, Scotland, and many parts of England are due to stagnation of soil water, and the removal of alkaline salts, but have nothing to do with the climate. Mountain peat, on the other hand, is a definite climatic product, as it invariably ceases in that form at altitudes below 1000 or 1500 feet, or practically at the limit of tree growth, apart from the stunted form of the latter capable of growing on peat itself.

For economic purposes the surface soils of the country may be roughly divided into three classes-first, soils formed on the more recent beds and drift-covered surfaces consisting of sand, gravel, clay, or loam of considerable depth; second, rocky surfaces generally bare of ordinary soil, but broken up by crevices, and pockets of soil or gravel, with which may be classed thin soils produced by the weathering of the softer rocks; third, surfaces covered with peat of various depths; fourth, practically bare rock, or surfaces carrying a soil not more than a few inches in depth, on an impervious subsoil.

Loamy clays and sandy loams are usually adapted for tillage or pasture, and are generally found under intensive agriculture, and no possibility at present exists of their becoming available for forestry purposes. Many of them carry a great deal of old woodland, game cover, and plantations adjoining parks and demesnes, and, managed on economic lines, they should produce a high return in timber. In the south of England they are often covered with coppice, which is incapable, under present market conditions, of giving much profit.

What proportions of the drift soils in the British Isles 
consist of sand and gravel is difficult to say without an exhaustive examination of the drift maps of the Geological Survey. It may be taken more or less for granted, however, that surfaces free from peat below 500 feet or so, and which are returned as mountain and heath lands in official returns, must be of that type, and probably most of the mountain below 1000 feet is either of this class or that classified under the second head. These soils are usually under rough pasture, and in a more or less unimproved condition, and are better adapted for forestry than anything else.

In mountain districts, however, these surfaces generally adjoin peat-covered land, and official returns do not assist one in forming any relative estimate of the extent of surface under one class or the other. In the lowlands, and keeping away from the low-lying bog areas in Scotland and Ireland, the greater part of the heath land may be estimated as plantable, and capable of growing timber of some kind. The south, midlands, and east of England, exclusive of parts of Cornwall and Devonshire, might be said with little exaggeration to contain no land incapable of producing timber. By far the greater proportion of these districts is under intensive agriculture, but probably from $2 \frac{1}{2}$ to 5 per cent. is, from a purely economic point of view, capable of profitable afforestation in the sense that rough grizing is the only agricultural use to which it can be put.

On certain calcareous formations, however, especially chalk, oolite, etc., the surface soil is too thin and the subsoil too impervious to carry profitable crops on the hill-tops, although they seldom exceed 800 or 900 feet elevation. Beech, larch, and such pines as Scots, Austrian, and Corsican, appear to be the only trees able to thrive sufficiently long to produce small timber on this class of land, and no evidence can be shown that would indicate 
the possibility of profit from planting it. The Cotswold Hills, Sussex, Wilts, and Dorset. Downs, and the high-lying tracts of Exmoor, Dartmoor, etc., may be regarded as unfavourable subjects for afforestation, although they may contain numerous valleys and ravines capable of producing good timber.

When the typical districts of Wales, and the north of England, Scotland, and Ireland are examined, however, it will be found that the surface varies in its character and fertility much more frequently than is indicated above. Valleys and glens show a surface closely resembling that of the most favoured portions of England, clays and loams of alluvial or glacial origin giving a fertile and easily cultivated surface, which is the more highly valued as it diminishes in extent, or as the valleys become narrower, and the population more congested in them. These fertile patches are invariably mixed up, first, with the gravel or shallow soils typical of the poorer parts of Southern England; and secondly, with the peaty or rocky surfaces falling under the third and fourth classes. The fertile soils are generally at elevations below 400 or 500 feet, according to the general elevation of the country. Between 400 and 800 feet the natural surface covering usually varies between scrub and second and third rate pasture. On the latter, hillocks and rocky points of high ground are interspersed with ravines or small valleys with deep and good soil, but not of sufficient extent to possess an agricultural value distinct from that of rough grazing.

This type of country is exceptionally well adapted for planting by the individual landowners, as, although the total area available for planting is large, it is too much broken up by holdings to adınit of afforestation on a scale large enongh to allow State action to be taken. On this type of surface many of the best wonded estates of 


\section{THE DEVELOPMENT OF BRITISH FORESTRY}

the country are found already, but a large extent of surface still awaits derelopment, and there is no reason why $2,000,000$ acres should not be added to the present acreage of private woods.

The sreater part of the surface aluove $s 00$ feet throughout Scotland, Wales, and the mountainous parts of England and Ireland are occupied by surfaces either bare of fertile soil or consisting of thinly curered rock either with or without a peaty corering. Above 1000 or 1200 fect the latter is mure universal, especially in the north and west, and on waterlogged soils generally, and is usually distinguishable from the peat formed at low levels by its ruying depth and irrezular surface, consisting of channels, liquid pools, and hillocks or hags standing above the surface level. The surfaces free from peat are either bare rosk consisting of exposed ends of beds dipping at various angles, ice-scraped granite, or loose boulders or rubble between which pockets and accumulations of soil occur, the two first named prevailing at hill summits and on steep or precipitous slopes, the last as the surface approaches the average of the lower levels. In the west of Ireland and scotland large areas of surface approach very closely to those found in the higher elevations in mountain districts generally, partly due to the damp and cool climate, partly to geological agencies, and the effect of glaciation. These surfaces are almost totally unfit for cultivation, and rery little better adapted for afforestation. Strong winds and sodden soils render these parts of the British Isles the most barren and sterile of the whole kinghdom, although numerous spots may be found among them which give results with certain species, the importance of which enthusiasts are inclined to exaggerate. Presence of shelter and porous soil, and absence of peat, provide conditions which are alone refuisite to enable many species like Sitka spruce, Thuir gigantea, Cupressus macrocarpa, or Douglas fir to 


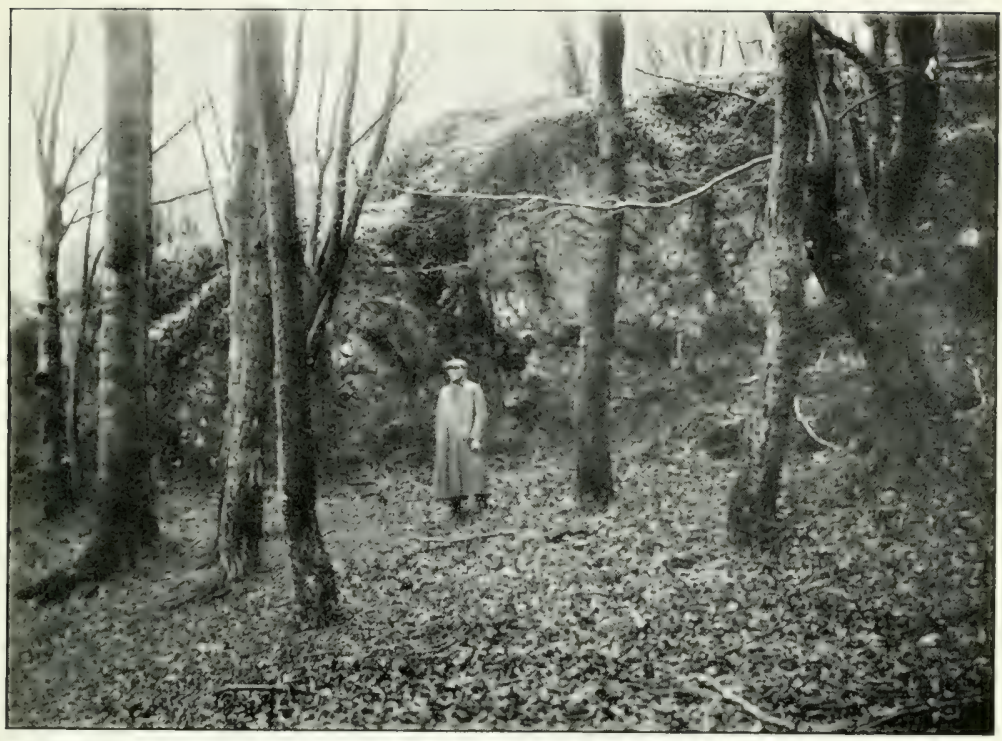

32. POCKET OF GOOD SOIL ON ROCK SURFACE.

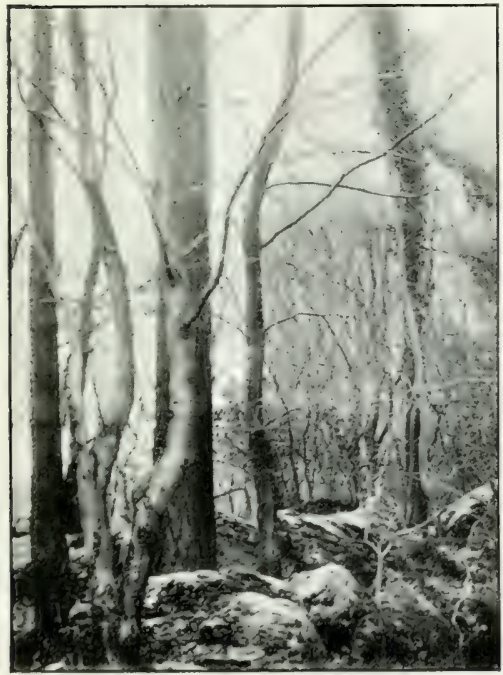

37. ASH. SYCAMORE ANI SCOTS PINE ON WEATHERED I.IMESTONH.

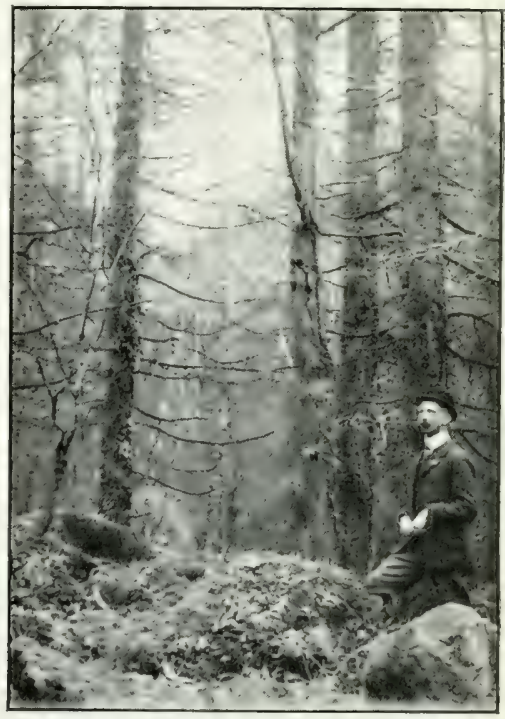

33. LARCH ON BOULDER-STREWN SURFACE. 

luxuriate for forty or fifty years, or until their tops get under the influence of the prevailing wind. But outside these favoured spots conditions are comparatively hopeless, so far as commercial timber is concerned.

So far as the planting or afforestation of the above classes of soils is concerned, the first and second demand no special attention. Land which is, or was, under grass or tillage, as practically all this class has been at one time or another, must be regarded as beyond the reach of the economic forester in a general way. Sandy and gravelly tracts, on the other hand, are better utilised under forest than in any other way, but it is scarcely necessary to differentiate between them and better land, so fur as sylvicultural principles are concerned. Grass, heather, bracken, gorse, etc., all demand special attention in preparing land for planting, but beyond breaking up the surface and subsequent clearing to prevent choking or smothering, the methods of planting are simple enough, and the afforestation of this class of land must be considered as a branch of rural economy differing little from the practice followed in the last two hundred or three hundred years throughout Europe.

But when the afforestation of the third and fourth classes are advocated, the fact must be recognised that a departure is taking place from all hitherto followed precedents, and new ground is about to be broken.

As already stated, the British Isles contain about $15,000,000$ acres of heath or mountain land, a certain proportion of which belongs to the second, but the greater portion to the third and fourth classes of surface described. Nuch of this land may be regarded as more or less favourable for planting, but from one-half to probably threefourths is of such a nature that it would be little short of madness to attempt its afforestation with our present knowledge.

The total area of mountain land over or under the 1000 
feet contour line in Great Britain is, in the first place, not known. Ramsay ${ }^{1}$ estimated that the southern half of Scotland contained 1,920,000 acres above 1000 feet, while in the Highlands of Scotland 280,000 acres were above 2000 feet. Estimates were made by the Board of Agriculture and Fisheries, for the purposes of the Royal Commission on Coast Erosion in 1909, of the land in Great Britain above 1500 feet, which was computed as follows:-England, 549,33う acres; Wales, 345,308 acres; Scotland, 2,642,529 acres. In Ireland, a country much less mountainous than Scotland, and probably not containing so much mountain land as the south of that country alone, an estimate of the land over 1000 feet amounted to 1,070,000 acres out of a total of 2,260,000 acres. Taking the entire mountain land of the British Isles as 15,000,000 acres, it can safely be reckoned that more than half is above that line, while a great deal below it is equally unfit for profitable afforestation.

All reliable authorities agree, however, that 1000 or 1200 feet represents the upper limit of profitable afforestation. Witnesses before the Coast Erosion Commission gave elevations varying from 1000 to 1500 feet, the latter figure being, in one instance, an isolated case referred to elsewhere. Messrs. J. P. Robertson and Payne-Gallwey, in their report on Derbyshire for the same Commission, regarded land over' 800 to 1200 feet as 'too high and exposed for profitable planting.' Mr. J. F. Annand, writing of Peeblesshire, probably one of the most suitable counties in Scotland for afforestation, states: 'I don't think you could go up successfully to 1200 feet with Scots pine, but on suitable land larch and also spruce go up quite well to 1200 feet.' Taking the average of wind-swept and sheltered aspects, it is generally admitted that 1000 feet marks the line at which planting for profit must stop.

1 Physical Geography and Geology of Great Britain. 


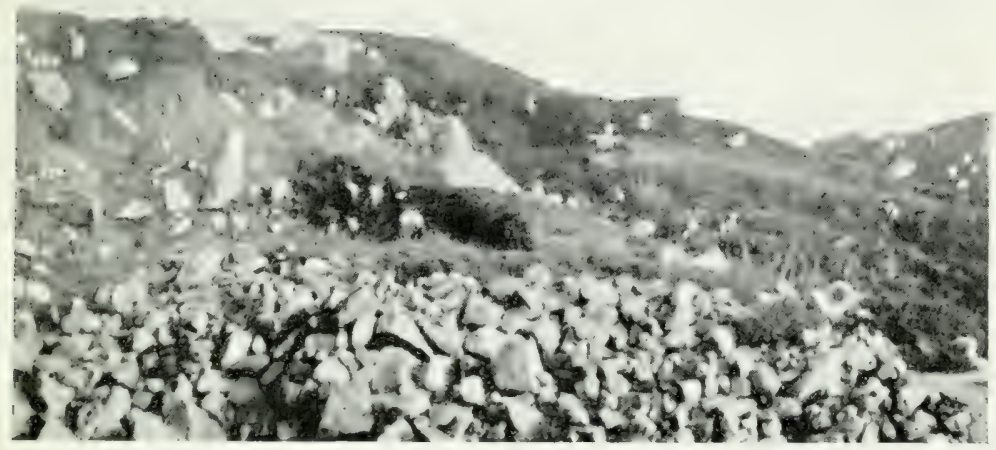

35. SURFACE COVERED With "DETRITUS" in DONEgal.

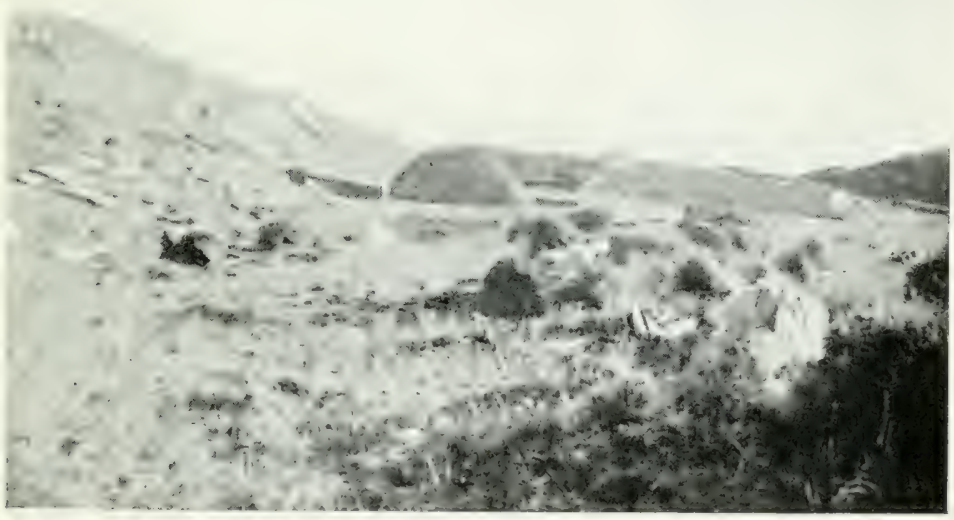

36. P'EAT HOG IN HOLLOW ON MOUNTAIN LAND. 




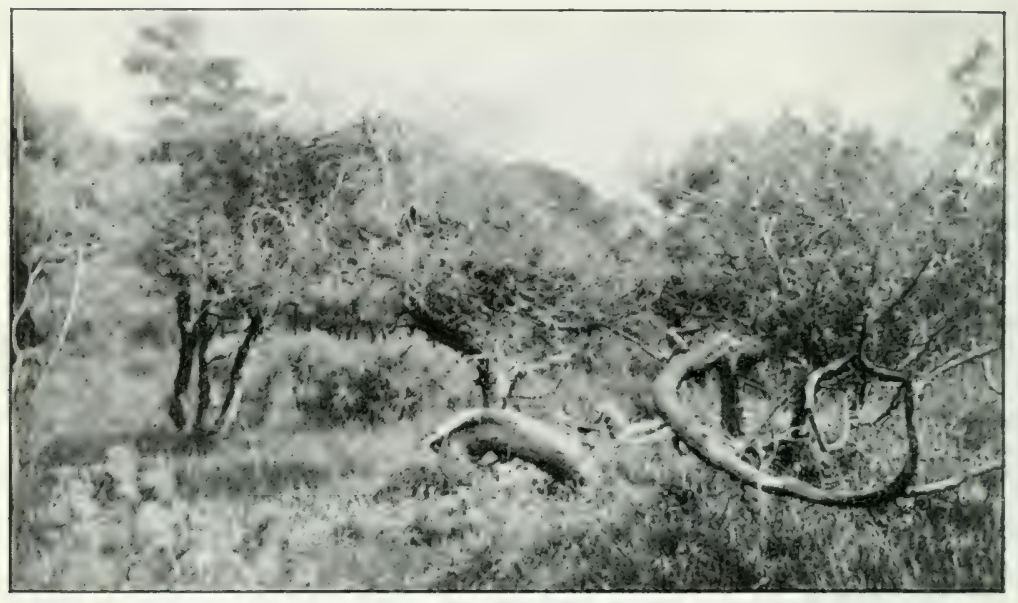

37. "Elfix" gRowth of Scots PiNe on shallow soll--8OOFT.

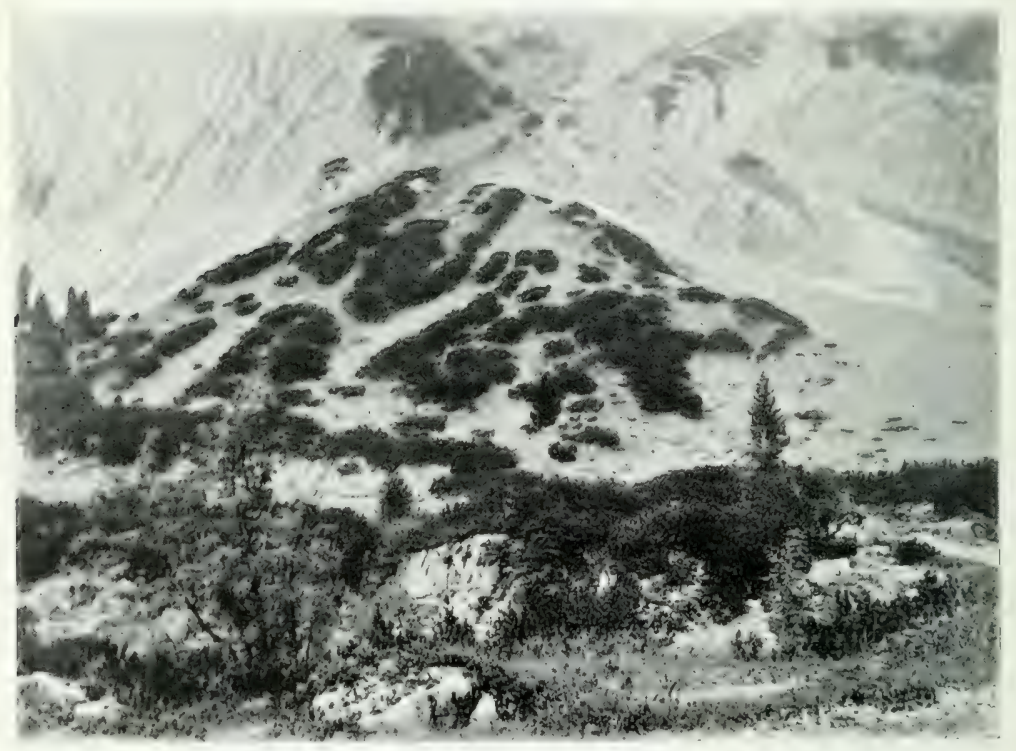

38. Nountaix Pine covering talus below snow line, 7,000 FT.

BAVARIAN ALPS. 
The bulk of this mountain land, in a general way, consists of ground which the agriculturist of the country, who has been steadily appropriating every acre of useful soil in the course of the last thousand years, has rejected as unfit for his purpose, and has consequently obligingly presented it to the sportsman and the grazier. The former values it for the sake of deer and grouse, the latter for the scanty pasture it produces for the summer grazing of sheep and store cattle. Its surface covering consists chiefly of heather, bracken, coarse grasses, rushes, gorse, etc., below the 1000 feet line, while above that level a layer of wet, spongy peat usually covers the natural soil, on the surface of which sphagnum and other mosses, lichen, etc., mixed with coarse grass or bog myrtle, usually predominate. In the west of Ireland, and in many parts of the Highlands of Scotland, this peat layer is spread over large areas at low elevations, except where boulders and ice-scraped rock surfaces have prevented its formation. On certain hill-ranges covered with porous soils the peat layer may not be found so low as 1000 feet, but it is fairly safe to say that the arerage condition of all land above 1000 feet in the British Isles is unfit for the intensive cultivation of either farm or forest crops.

Within the last fifty years, but more especially in the last twenty, rural economists and forestry enthusiasts have paid much attention to this class of land. On the Continent of Europe, land which is too poor or mountainous for successful cultivation invariably carries a crop of trees up to an elevation of 2000,3000 , or 4000 feet, according to latitude and surface conditions. British cconomists ask why the waste lands of Britain may not be similarly covered with woods, and the government and private landowners have been loudly called up on to remedy this grave deficiency in land utilisation, and by means of planting or sowing add to the beauty of the 
landscape, and the wealth of the country in one operation. The imagination of such economists, when once roused, is often allowed to run riot, and the land, which now presents to the eye a landscape of variegated browns, purple, greens and greys of heather, bracken and grass, is in imagination clothed from summit to base with serried ranks of pine, spruce, or larch, or the bosky billows of beech or chestnut. The Harz Mountains or the Black Forest are reproduced on every mountain range in the British Isles, and the land now given over to sheep, grouse, or deer devoted to timber production. The lonely shepherd and his dog, who now watch over 1000 acres or more of mountain, become a memory of the past, and the hum of the saw-mill, and the rusticity of forest villages bring untold wealth to the nation, and the simple life to its inhabitants.

The process by which this entrancing picture is to be produced is equally simple and devoid of difficulties. The land is to be acquired - whether by buying, begging, borrowing, or stealing matters little to the enthusiast. Then, as if by a merciful dispensation of Providence, there exists a vast army of unemployed in every town and city. Disregarding for the moment troublesome details, this army of unemployed, of various ages, sizes, and degrees of incompetency, is to be spread out into a thin multi-coloured line at the end of a mountain range, provided with spades and young trees, and given the order to march. In front of the army lies the bare waste and barren rock of a desolate land. Behind it is left a promising young forest. If the army is too small or the funds are limited, squares or sections are divided off in the manner most convenient to the planter, and in place of planting the whole, large plantations or in lividual forests are formed instead of forest regions.

Another side of the mental vision succeeding the above 



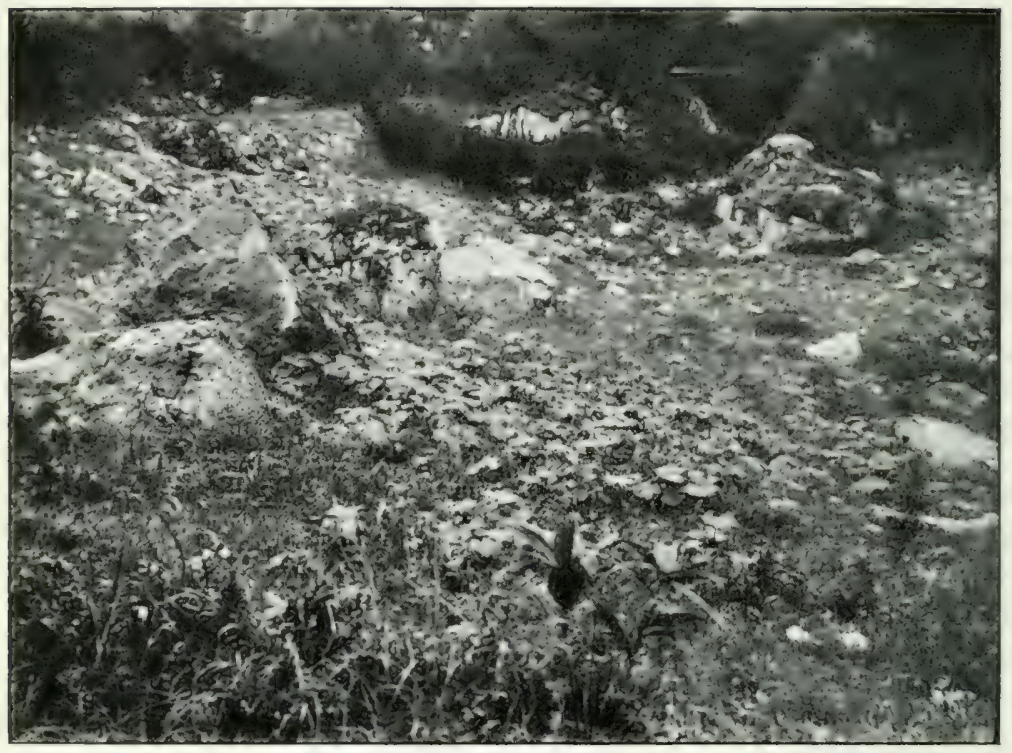

39. SURFACE COTERED WTI GRASS AND HERBACEOUS P'tANTS. 6000 FT. BAVARIAN AI.PS.

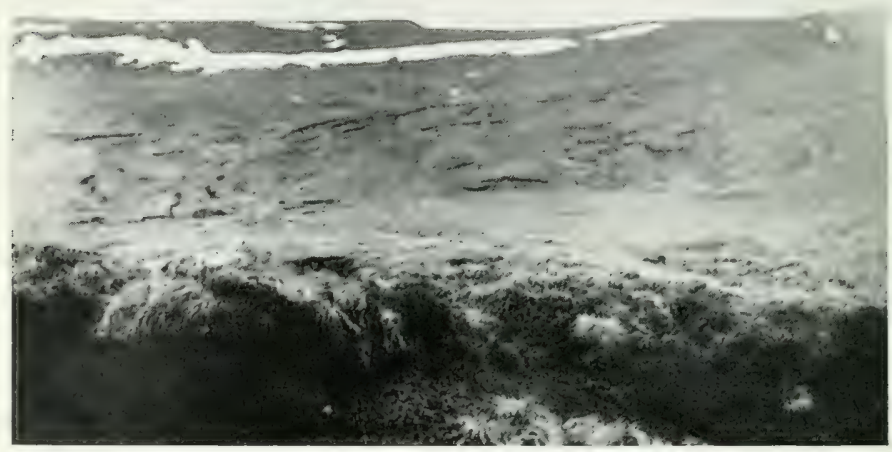

40. P'eat-covereis slopes on P'ennines, 2,000-3,000 Ft. 
is that in which thriving industries accompany the exploitation of the mature timber, and saw mills, pulp factories, chemical works, and innumerable minor manufactures and cottage industries, finding employment for thousands of happy workers, appear. Waste land, bare rocks, peat bogs, and even the spoil heaps of mines are to disappear, and every city is to grow its own building timber, and every colliery its own pit wood. The more practical the enthusiast, the greater the dilution of the above picture, until it is gradually reduced in size, and toned down in colour, to practically the same state of affairs as exists to-day.

Suggestions are, again, frequently made that the fertility of mountain land would increase under a forest crop, and that it might in time be quite an easy matter to plant trees up to 2000 feet above sea-level, by reason of the increasing shelter and soil fertility which would follow the afforestation of the lower slopes. The writer was made responsible by the Royal Commission on Coast Erosion for the statement that land on the Pennine chain had producel profitable timber crops at an elevation of 1500 feet. While this is an undeniable fact, it was also carefully pointed out that the results obtained in the instance quoted were due to exceptional conditions which rnight not be found in half a dozen places elsewhere in the British Isles. In the first place, the land was particularly well sheltered for such an elevation; in the second, it was almost free from peat; and last, but probably not least, the soil was unusually well prepared after the first crop of trees had proved a failure. ${ }^{1}$ Similar conditions are not casily found at the same or even lower elevations, and vast areas of mountain land are so exposed, and the soil on them in such an unfavourable condition for plant growth, that no conceivable improve-

1 Vide Trans, Roy. Scot. Arbor. Soc, vol. xx, part i. 
ment on the lines suggested would make them good sites for profitable timber crops.

On all peat-covered land the first process of improvement is to drain the surface, not merely of the peat itself, but also of the natural soil below. This surface, however, is usually so rough and irregular with stones, boulders, and outcrops of rock that no drain of any length could possibly be made in it which would possess a steady fall. Where such rocky obstructions are absent, the surface is in most instances already drained by natural channels, and on such spots as these planting has the greatest chance of success. But the more frequent state of things is the first-mentioned condition, which may be considered almost hopeless. Where, however, the peat is sufficiently thick, and possesses an unbroken and uniform surface, as on the deeper bogs of the lowlands, soil drainage may be dispensed with to some extent, as the layer of peat is in itself deep enough for the trees. To bring it into a fit condition, however, time and labour must be freely spent. Live peat-that is, peat which is still adding to its depth by the upward growth of sphagnum and other forms of vegetation-cannot support tree growth; Scots pine, mountain pine, maritime pine, alder, willow, birch, and possibly a few other species will live in it for a time, and produce a sickly and stunterl growth, but timber, in the ordinary sense of the word, is out of the question on unprepared peat. To fit it in any way for timber production it must first be thoroughly drained, so that all stagnant water is removed, and this will eventually result in the death and decay of the peat-producing plants apart from heather and other dry-soil forms of vegetation which often frequent sour or leached-out soils. This drainage may, if effectually carried out, cost $£ 2$ or $£ 3$ per acre at the outset, and a certain expenditure must be incurred from time to time in maintaining it. The 
next step in the process of reclamation consists in the breaking up of the tough fibrous surface which invariably characterises dry or drained peat, and which is practically as objectionable from the planter's point of riew as the wet, spongy form. This tough layer usually consists of the roots of such plants as heather, sedge, rushes, and species of grasses, and occasionally bracken and gorse. Tree roots placed in this layer might almost as well be lying between two sheets of leather, for all the good they are likely to get out of it, until their roots strike beyond it into the soil below. In dry weather the peat contracts and opens up, leaving the roots almost bare. In wet weather and winter the sodden peat surrounds the roots on all sides, charged with humic and other acids, which are anything but conducive to root action. A few of the species above named may be able to secure a weak footing in this substance, but the majority of trees die out altogether after a few months or years. When the surface is thoroughly broken up, either by taking off two or three feet en bloc, which is the most satisfactory but extremely expensive method, or by covering it with some growth which will kill out the surface plants, a mild form of decomposition or weathering is set up which renders the peat somewhat more suitable for tree-growing. The action of frost freezes the moisture in the upper few inches, and probably plays an important part in breaking down fibrous peat into a loose mould, but this action is impossible till the surface growth is destroyed. The most satisfactory surface covering for effecting this is probably a thick crop of some easily satisfied tree, which will produce a dense shade and surface covering of dear leaves, and kill out all surfice vergetation after a few years. Trees such as these have been found in birch, mountain pine, Banks's pine, white American spruce, and others capable of thriving in the peat after a certain amount of 


\section{THE DEVELOPMENT OF BRITISH FORESTRY}

drainage has been carried out, and eventually able to cover the surface with a thick uniform leaf canopy which fulfils the desired object sooner or later.

But however useful such crops as the above may be in improving the surface, and providing shelter for subsequent planting, they are not in themselves capable of producing commercial timber on anything but the most diminutive scale. None of them is able to attain a greater height than thirty, forty, or possibly fifty feet, while the cubic contents of individual trees scarcely entitle them to be termed timber. Apart from firewood, and the production of poles for fencing or pit wood, the produce of what inay be termed 'preliminary crops' is of little commercial value. This has been found out in Denmark, SchleswigHolstein, Prussia, Holland, and other European countries in which attempts have been made to afforest excessively poor or exposed heaths and sands, and the introduction of more valuable species at a later period has not as yet led to much more satisfactory results.

The fact still remains, although this point is often forgotten, that after all possible improvenent of the surface of mountain peat, the soil still remains only a poor one at the best, and only capable of producing poor crops. It is conceivable that successive generations may in course of time give a satisfactory soil at last, but there is not the slightest possibility, under present conditions, that the ultimate returns from such wastes will ever repay the money spent on reclaiming them, or yield any interest on the capital invested.

The cost of draining, fencing, preparing the surface, and planting with soil-improving crops, as the case may be, cannot be carried out for less than $£ 5$ or $£ 6$ per acre under the most favourable conditions. In most cases $£ 10$ would be nearer the mark. Assuming that the crop thus produced stands for a period of twenty years before 


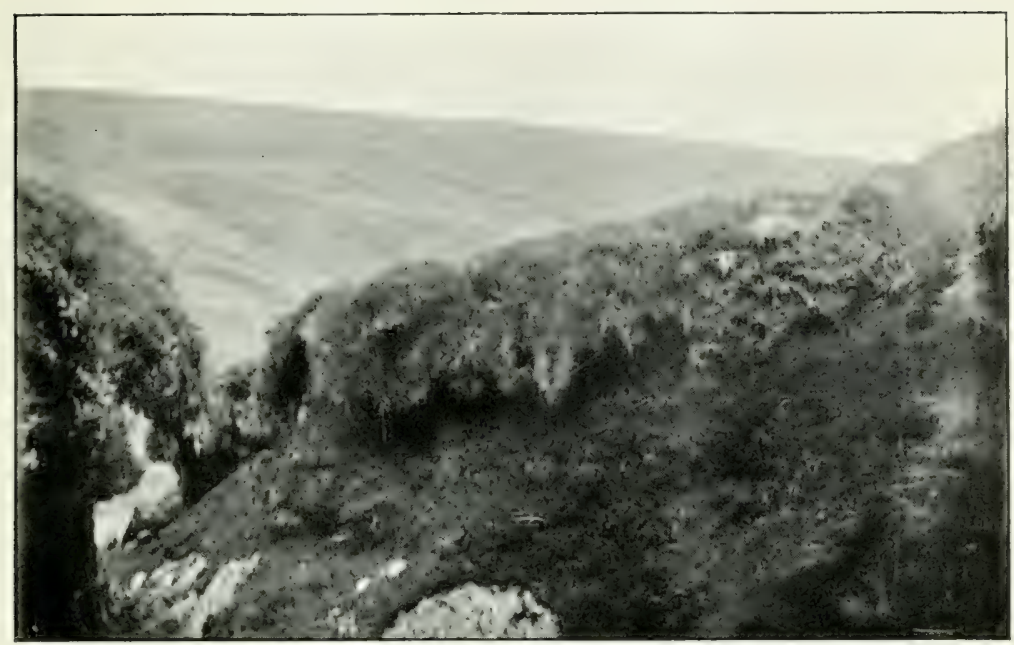

4I. Natural chanxels in mouxtary peat resting on boulder clay. $2,000 \mathrm{FT}$,

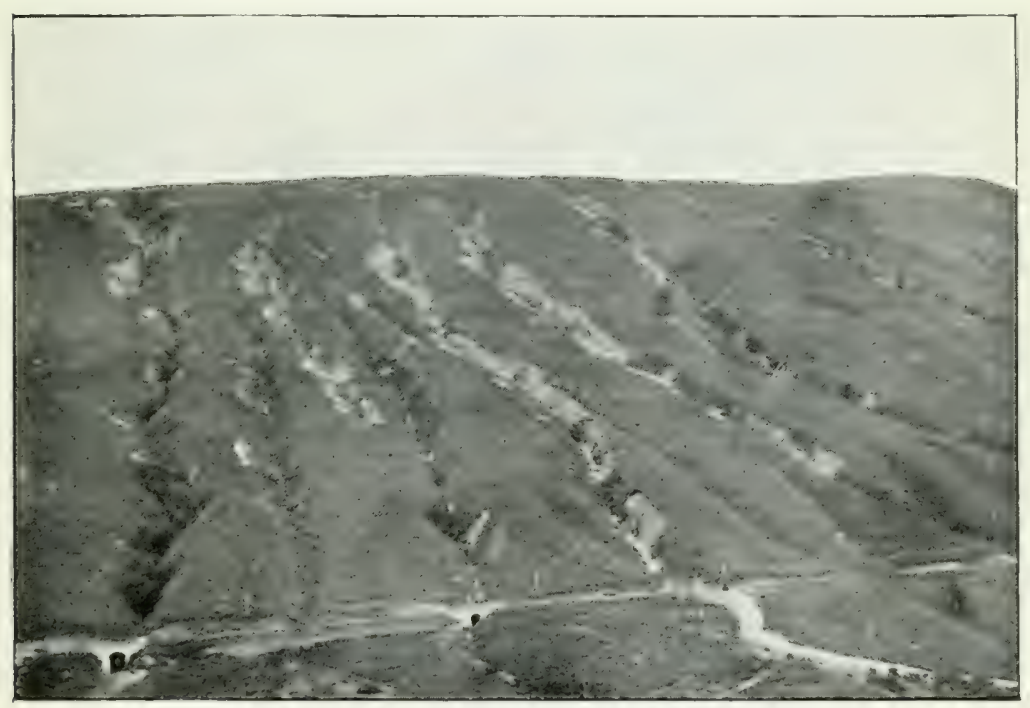

42. SURFACE DENUDATION ON HIL SIDE. WEST HIGHLANiS. 

trees of a more valuable species can be introduced, it is found that $£ 10$ to $£ 15$ per acre is the lowest amount that can be named which will cover initial cost and compound interest previous to the planting of the timber crop proper.

The cost of putting in the latter will probably vary from $£ 3$ to $£ \check{b}$ per acre, according to species introduced, and an average figure of $£ 4$ will not be far out. This makes from $£ 15$ to $£ 20$ in all as the total cost of afforestation, including preliminary and timber crops. The question then remains, will the crop thus produced be of sufficient value to justify this expense? In the more sheltered districts, enabling the climate to make good some of the deficiences of the soil, good management may give, at the end of a fifty to sixty years' rotation, an average yield of about 2000 to 3000 feet per acre of such species as spruce or larch. The highest possible value that could be placed on a crop of this kind would be $4 d$. per cubic foot all round, assuming two-thirds to consist of spruce and one-third larch, making a total value of $£ 30$ to $£ 50$, from which costs of formation and management must be deducted. The latter, of course, varies with the size of the area and other circumstances, but at the lowest it cannot be less than 2s. 6d. per acre, taking every item into account expended over a long period. Without going into exact figures it is evident, therefore, that the returns from lands of this class cannot do more than pay expenses under the most favourable circumstances, unless current prices for small timber rise two or threefold in the future.

The question is often asked why trees should not grow at the same elevation to-day as those found under the peat and mountain slopes 2000 feet or more above sealevel. The question may be answered in a way by pointing out that these trees were usually growing in the 
natural soil below the peat, and that possibly similar results might be obtained again if the peat were absent. But such an answer does not explain the fact that trees were growing upon the peat itself and subsequently died out, nor why the peat took the place of natural forest at some distant date, nor does it explain why trees planted at similar elevations to-day, but on soils free from peat, invariably fail, or grow into worthless scrub at the best.

Geikie, Smith, Lewis, and other investigators of peat and moor formations have been able to trace indications of varying climatic phases of the temperate, arctic, and sub-arctic character, clearly suggesting that alternations of dry and wet periods have taken place since the peat beds of these islands began to form. In most beds two distinct periods of forest growth are found, the lower indicating a broad leaf, the upper a coniferous or pine type. Probably the mountain-tree remains belong to the latter period, as they are seldom covered by more than four or five feet of peat, although much of it may have been denuded by wind and rain.

It is possible that the development of mountain peat in the British Isles alone has been assisted by the heavy autumn and winter rainfall, and the general absence of snow and frost during the winter. Heavy rainfall at a season of the year when most forms of vegetation are dormant, and the surface more or less bare, favours the washing out of soluble salts, whereas under a snow covering the products of weathering would be preserved near the surface until the following spring, and largely utilised by growing plants. Mild winters and cool summers also favour the growth of sphagnum, which is seldom entirely checked by cold or drought, and quickly fills up the drainage channels which are formed by heavy rain storms, except where they run down the steeper slopes, or carry streams of constant flow. 



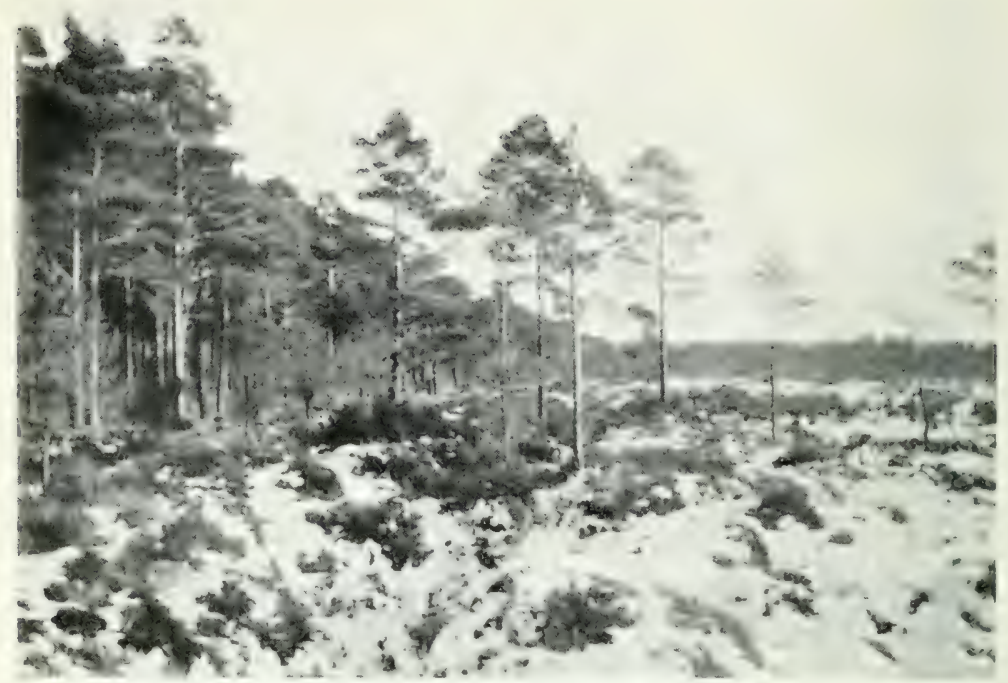

43. Scots Pine on "High" BOG, IREIANI). TREes in BaCkground SHOWN IX Fig. 44 .

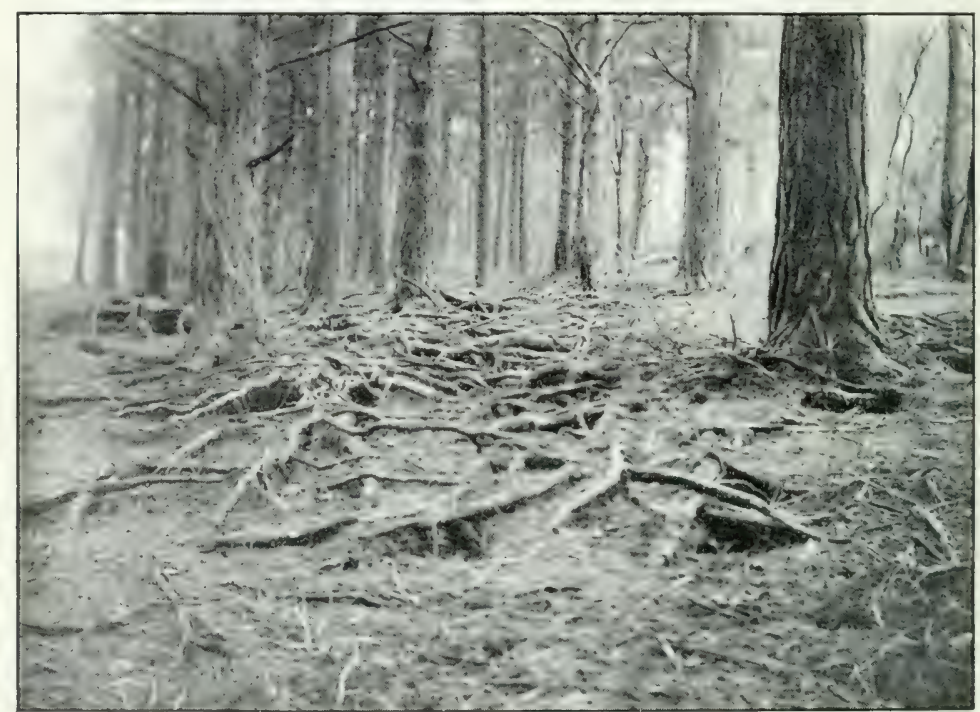

44. SCOTS P'INE ON "CUT-AWAY" BOG. 
With exposure to wind and increasing altitude the necessity for good or productive soil invariably increases. Experience has proved again and again that planting on poor or peat-corered soil, in the face of the wind, will not succeed with ordinary timber species, although hardy trees like mountain pine, white American spruce, or others, may form some sort of shelter, and possibly pave the way for better results later on. On private estates failures on poor, exposed soils are numerous, but as they cannot always be accounted for on ordinary physical or sylvicultural grounds, owing to the past history of the plantation being unknown, it is not advisable to lay much stress upon them. Every practical forester, however, can judge the cause of failure for himself, and in most cases bad soil is known to be the cause.

Attempts by the State or public bodies in planting exposed land are brought more prominently into view, and several instances may be quoted to prove that the waste lands of the British Isles cannot be afforested with that simplicity and freedom from failure which many would have us believe.

The most disastrous attempt at planting exposed land was that at Knockboy in Counemara, where some 500 acres of wind-swept land, near the sea-level, were planted under the supervision of the Congested Districts Board for Ireland between 1892-1896. This land was a wet, peat-covered tract of the typical Connemara type, and was drained and fenced, and every possible tree tried both by planting and sowing. The total cost amounted to about $£ 7$ per acre for plants and planting, and the final result up to date has been the production of a thin and patchy crop of mountain pine, Scots pine, and a few other trees which have succeeded in getting level with the heather after a period of over fifteen years. On occasional spots where natural soil and sheltered valleys occur, a 
fow lareh, mountain, maritime, and Corsican pines may bo found likely to grow to fencing poles or pit props if protected, but the general result has been, in the words of a witness before the Departmental Committee on Irish Forestry, ' a failure.'

In the Isle of Man the Office of Woods and Forests planted in 1593-1594 nearly 400 acres of land at an elevation of 500 to 700 feet, which turned out a complete failure, exactly as in the case of Knockboy. In the following year 225 acres of adjoining lind facing the north-east were planted at an altitude of 700 to 1100 feet. The upper part of this also failed. In 1889,167 acres were planted at an altitude of 300 to 1100 feet, and the upper half of this behaved in the same way.

These instances are not given as a proof that afforestation on pror soils and exposed sites is impossible, but as an indication of what happened in the past and may easily happen in the future if obvious facts are disregarded. In these and similar cases the failures gradually disappear and are forgotten. The successes alone remain. But the forester is not yet born, and probably never will be found, who can predict, with absolute certainty, the result of planting exposed or very poor land.

On ground free from peat much more hopeful cases for afforestation may be met with. These will usually be well within the zone of cultivated holdings, although not necessarily on them. To deal with this class of land alone, however, is really the only sound policy to adopt in British forestry, whether actual or prospective, unless planting for shelter or landscape is the object in view. Fairly deep and porous gravels, carrying a natural growth of bracken, coarse grass, etc., exist to a limited extent in many parts of the country, and if the unbroken areas they occupy are not large individually, they are usually sufficient to form a nucleus for afforestation work, and can be extended as 


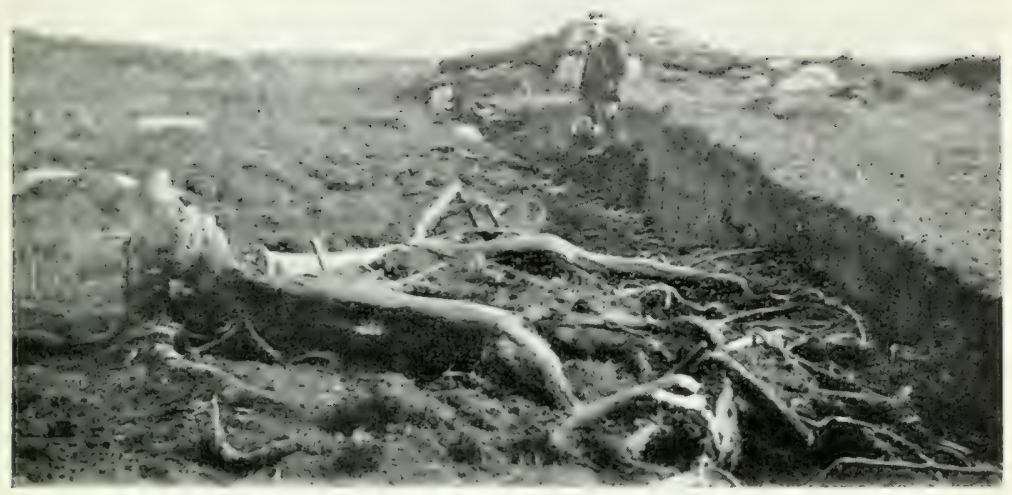

45. RoOts of Scots Pine in mountain peat. Donegal.

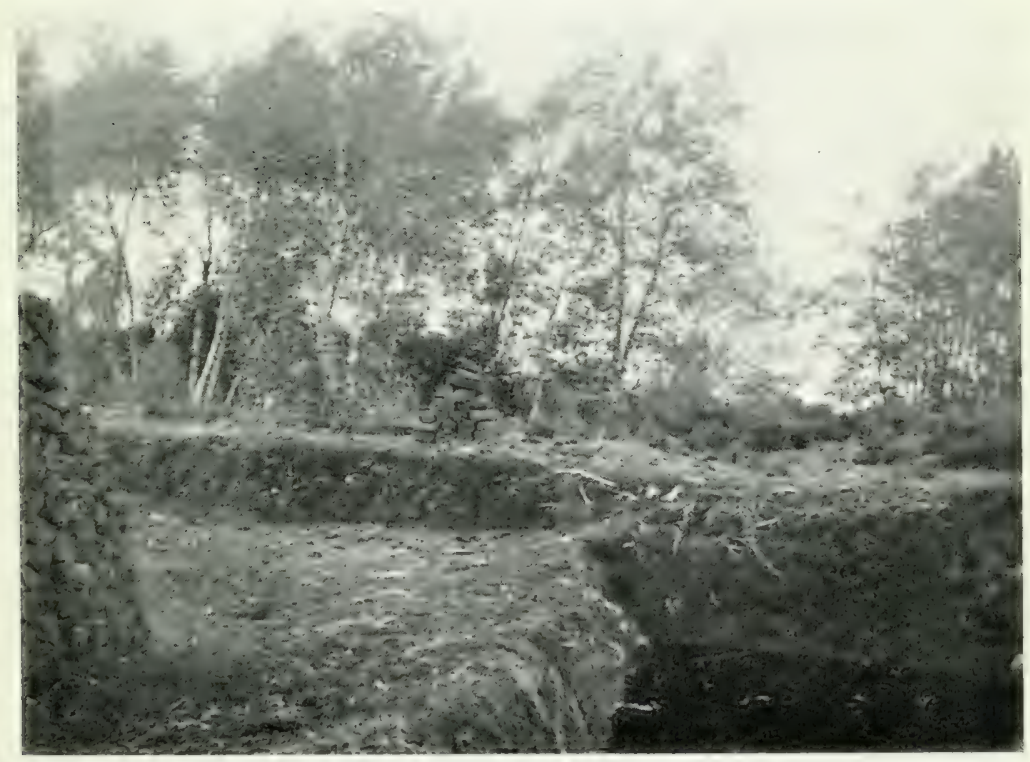

46. Naturai. BirCli ON BOG. 

opportunities occur. In a country such as Great Britain, where every acre of agricultural land has been appropriated for one purpose or another for centuries back, it is impossible to obtain large areas of suitable land in solid blocks of more than 500 to 1000 acres in extent. Larger areas than these either include a certain proportion of useless land, or embrace agricultural holdings which are already producing more wealth to the nation generally than they would do under afforestation.

Whether the acquisition of a certain proportion of the latter for planting purposes is justifiable or not is an open question, but it is obvious that the large individual forest areas found abroad are on land of this class, although they may possibly have been under forest from the first. If Great Britain is to secure a forest area representing from 5 to 10 per cent. of the total area of the country, it is safe to say that the agriculturist or grazier must be asked to give up, as already stated, from 2,000,000 to $4,000,000$ acres of land, which now possesses a rental value of from 2s. 6d. to 5s. per acre per annum for grazing purposes, and is probably yielding a gross return of $10 \mathrm{~s}$. to $20 \mathrm{~s}$. 


\section{CHAP'TER VI}

THE NEED FOR IMPROVED METHODS AND PRACTICE IN BRITISH FORESTRY

OF the various features of British as compared with continental forestry three stand out fairly conspicuously: (1) the small size of British woods; (2) their mixed or indefinite character; and (3) their lack of density and deficient yield during their early and middle stages of development, and the low quality of the matured timber. On the first of these features some light has already been thrown, and it is unnecessary to repeat it here. The general results of the other two must be largely attributed to the absence of economic principles in the management of British woods, which accounts for the fact that definite crops grown on definite rotations are seldom if ever met with, the result being that trees and woods are cut long before or long after being mature, as the case may be, and are placed on the market more or less irrespective of their abilities to meet the requirements of any particular trade or industry. One has only to compare the return in cubic feet from an average acre of British woodland with that obtained from forests properly managed in Central Europe, to see how deficient they are in all qualities that combine to make woodland management profitable.

But the low yield of British woods is probably due not so much to the general ignorance of the systems of wood management, as to methods of planting, thinning, and felling, which, while probably sound in principle, are 148 
improperly or carelessly carried out, or rendered abortive by incidental circumstances. Whether broad-leaved or coniferous woods, worked on long or short rotations are considered, the difference is quite as marked, and personal observation renders the disparity between the possible and actual yield in commercial timber even more conspicuous than figures and quotations. Compare a wood consisting of short-boled, heavily crowned trees, scattered over a surface covered with bracken, brambles, grass, or heather, with a crop of tall branchless stems rising from a leaf-strewn floor absolutely free from all forms of herbage. Not only is the former deficient in cubic contents, so far as mere wood is concerned, but the proportion of waste or firewood to commercial timber in it is from three to four times as great as that found in the latter. The difference is quite as great as may be seen in two whent crops, the one thick, even, and level as the surface of a lake, and the other full of poppies, thistles, and binclweed, the result of bad cultivation and dirty ground.

To what, it may be asked, is this difference due? Is it to inditierence on the part of owners of woods, and ignorance on the part of their foresters, or to objects being kept in view other than the production of timber? That all three of these causes have had something to do with the unsatisfactory features alluded to is well known, and fully described in another work, ${ }^{1}$ but there are other reasons which may be found upon a careful scrutiny of the conditions under which plantations are raised, either on bare ground or cleared woodland.

In the first place, it must be admitted that thin or badly grown woods may arise from the inroads of ground game, wind, or the result of deliberate thinning during the first twenty or thirty years, and there are few estates throughout the country which do not show examples of

1 English Estate Forestry. 
such. But the universal condition of British woods cannot be altogether attributed to these causes, for unless the crop consists of a shallow-rooting species easily orerturned by wind, or the woods are entirely given up to ground game from the first, it is seldom that the bulk of timber produced at the final felling is necessarily affected, although its quality may be, and its intermediate yields reduced. With a thin stock on the ground during the first ten to twenty years, as usually happens when plantations have suffered from early deaths, wind damage, or rabbits, the yield of timber from them is chiefly reduced during the period between the twenticth and fiftieth years, or the period during which, in properly managed woods, the heariest and most profitable thinnings are made for the benefit of the maturing crop. The great difference in the number of stems per acre in British and continental woods is thus found in the early stages, and this difference is usually increased with the shade-bearing qualities of the species composing the crops.

The following table shows the number of stems at different ages usually found in German woods in firstclass localities, as given in yield tables by Schwappach and others:-

\begin{tabular}{|c|c|c|c|}
\hline \multirow{2}{*}{ Age. } & \multicolumn{3}{|c|}{ Stems per Acre. } \\
\hline & Scots Pine. & Spruce. & Beech. \\
\hline 20 & 1700 & 6000 & 2500 \\
\hline 30 & 1050 & 1800 & 1500 \\
\hline 40 & 700 & 1300 & 900 \\
\hline 50 & 460 & 700 & 600 \\
\hline 60 & 330 & 600 & 400 \\
\hline 70 & 260 & 500 & 330 \\
\hline 80 & 210 & 450 & 260 \\
\hline 90. & 200 & 400 & 220 \\
\hline 100 & 108 & 350 & 200 \\
\hline
\end{tabular}


The above figures show that with the thickest possible planting, and subsequent crowding, the number of stems per acre is reduced by the fiftieth year to 460 in the case of Scots pine, to 600 in the case of beech, and 700 with spruce. Any plantation in Britain under average mauagement would not fall far short of these figures at fifty years, although planting of pure beech woods is not common enough to make a reliable comparison. But taking mixed woods instead of pure, it is clear that the low yields of mature timber from British woods cannot be altogether due to thin planting, although it is sometimes assumed that such is the case.

It is true that many continental forester's plant, or produce by sowing, ten to twenty times the above numbers of trees per acre at the outset, and from a purely sylvicultural point of view they are probably right. The greater the number of trees planted or sown per acre, the greater will be the number of individuals present which show an exceptional vigour of growth, a greater power of resisting unfavourable climatic influences, or of accommodating themselves to a particular soil or situation. With thick cropping, the process of natural selection comes more naturally into play, and the resulting crop is likely to be better and finer in every way.

But from an economic point of view the question of thick planting is closely bound up with two factors, expense and early yield from thinnings. With sowing, or the planting of two-year seedlings from a seed bed, the cost of stocking ground with 5000 to 10,000 plants per acre need not be greater than the planting of 2000 or 3000 four-year plants by slitting or pitting. On many soils, however, the use of seedlings dices not lead to successful results, owing to ground game, weeds, rublish, etc., or if these are kept down by trapping and cleaning, to 
cheaper work than that done in the ordinary way. It is most often profitable where pure crops are grown of a species which produces seed in abundance, and on ground which carries a typical woodland surface flora which does not tend to smother the plants. It is with sucin species and under such soil conditions that the majority of continental crops are raised, and for these reasons it is possible that the methods practised by continental foresters have been maintained for so long a period in spite of the increasing cost of labour, and the bad results which occasionally follow overcrowding in youth.

The custom of sowing or planting pure crops goes back to the earliest days of practical forestry. Natural forests are rarely pure, but one species usually predominates, and under favourable conditions produces pure groups of greater or less extent. Beech, spruce, and silver fir are more often found pure than other species on account of their ability to kill out weaker neighbours, and their power of reproducing under thick shade. These pure groups, however, rarely extend over large areas, as differences of soil or situation produce varying conditions which give one species the advantage here and another there. Occasionally one comes across a natural mixture of two species, either of which is able to hold its own against its neighbour, but more often the mixture can only continue when a light-demanding species is found with a slow-growing and subordinate shade-bearer. Another cause of naturally mixed woods is the open order in which the various species often stand, owing to irregularity of seeding, or the existence of surface growth which prevents uniform cropping, etc. Hence it happens that the better the soil, and the more varied and stronger the ground flora, the greater the tendency for natural woods to be mixed, while on rery poor soils, or those strongly 
marked by special characters, and at high altitudes, pure woods, or woods consisting of a few species only, are frequently met with. The broad-leared forests of the lowlands are, for instance, usually mixed; those of the mountains and peat bogs pure; but, of course, local rariations occur in all natural forests which give a mixed character to large areas wherever they occur.

When woods came to be artificially raised, foresters naturally confined themselves to the species best fitted to the soil, or best calculated to yield a profit when grown. Pure crops are easily managed, give a high yield per acre, and enable demands for special kinds of timber to be met. But many distinguished foresters believe that insect and fungoid pests are able to commit far greater damage in the pure woods of modern forestry than was the case a century or two ago. Caterpillars or larvæ which spread from tree to tree in search of food find life much easier when the crowns of the trees are interlaced than when they are isolated or separated by species which do not serve their purpose. Parasitic fungi find a greater number of fit individuals for infection amongst the suppressed trees of a pure wood than when these suppressed trees are absent, or consist of another and immune species. The soil, again, may possibly get sick of a species grown on it century after century, although it cannot be said that much evidence of this is as yet forthcoming. With light-demanding species, again, the ground becomes so dirty, and covered with such injurious forms of vegetation as heath, bracken, wood rush, etc., that eventually pure crops lead to the deterioration of the soil. For these and other reasons mixed crops are probably more in harmony with nature than pure woods over wide areas.

But to produce satisfactory financial results the mixtures adopted must be formed on correct principles. The orthodox mixture in most cases is that of a shade- 


\section{THE DEVELOPIENT OF BRITISH FORESTRY}

bearer and a light-demander-as, for instance, oak and beech, larch and beech or silver fir, or Scots pine and spruce. But the value of such mixtures, and the results produced by them, depend very largely upon the soil and climate. On very thin or wet soils, or in wet and cold climates, the mixture may not prove so successful as the pure crop. Underplanting of a Scots pine wood on poor gravel in a cold, wet district may not produce any good results, as the shade-bearer will be unable to acquire sufficient strength and vigour to benetit the pine by soilshading and production of humus, while the preservation of moisture, which would result from this humus layer, would be an unnecessiry advantago in most cases. Hard and fast lines for the formation of cither pure or mixed woods, therefore, cannot be laid down in all cases, and the general conclusion that inust be arrived at from a careful consideration of facts is, that groups of different species, either pure or in suitable mixture, are preferable to large unbroken areas of either one kind or the other.

To the British forester the mixed plantation is a familiar object, whether good or bad. Occasionally larch, Scots pine, and other species are planted pure, but the more general practice, especially on good soil, is to put in a mixture of conifers and broad-leaved trees, varying in number of species from ten to twenty, according to the ideas of the planter. These mixtures are usually bad, for reasons which are well known to most foresters, and to them may be traced almost entirely the bad quality and low yields of timber complained of. ${ }^{1}$

The question of suitable mixtures is of the greatest importance in British woodlands. An ideal mixture might be regarded as composed of four constituents. First, the species which will develop into the profitable crop at the end of the rotation adopted. Second, the

1 Vide English Estate Forestry. 
species which will aid the development of the permanent crop and create and maintain suitable soil conditions, and protect the crop against wind. Third, a species which will act as nurses, and yield some return in the shape of thinnings before the thirtieth or fortieth year. And fourth, trees which will suppress and kill out surface vegetation during the first ten or fifteen years after planting. The two former species may be regarded as permanent and indispensable; the two latter as temporary components of a forest crop, which may or may not be regarded as necessary according to circumstances.

The commercial value of hardy species is dealt with elsewhere, and all that need be stated here are the general principles involved in forming mixtures. It is an accepted principle in sylviculture that a correct mixture should always contain a shade-bearing species to maintain the surface soil in a fertile state. It is equally important that a mixture should contain a wind-firm species, except perhaps in the most sheltered situations. Species for yielding valuable thinnings are necessary from an economic rather than a sylvicultural point of view. The ultimate development and maturing of the crop are not affected one way or the other by them, but the nett profits are considerably influenced by species which can save the working expenses of the crop after the twentieth year. Surface-covering species are chiefly necessary on poor, thin, exposed, or peaty soils, on which the trees of the permanent crop have a hard struggle to establish themselves, either owing to poverty in the first few inches of soil, or to exposure to wind.

So far as permanent crops are concerned, mixtures are not necessary for soil protection in the case of shadebearers, but are frequently required for wind resistance. Silver fir and beech, for instance, can stand alc ne withcut any danger to themselves, or deterioration of the soil. 
Spruce, on the other hand, frequently suffers from wind when planted alone, but much depends upon the soil and situation. Light-demanding species invariably require growing in mixture, especially larch and oak, neither of which are able to shade the ground sufficiently to suppress surface growth after the first forty or fifty years. The former also requires a wind-resisting species with it on exposed sites. Light-demanders which may be successfully grown either pure or in mixture are pines, ash, sycamore, poplar, alder, willows, etc. The question of mixing any of these is more a matter of economy than of sylviculture. Districts in which labour supply is deficient, and little or no sale for thinnings exists, are best suited for pure crops, as the latter require less attention when young, and can be mere rapidly disposed of in large quantities when mature. Differences of soil and situation must, of course, be studied in all cases, and under average British conditions pure crops, if formed on correct principles, rarely occupy more than two or three acres in one block, although the total area under a given species may predominate very greatly over that occupied by the remainder.

What may be termed 'main-crop developers' should be important features in all mixtures having light-demanding, shallow-rooting, or wind-sensitive species for the main crop. On damp, fresh soil, or in deep, sheltered ralleys they are least required, but on average soils and situations they may make all the difference between the success and failure of the main crop. The main functions of this class of tree are the thickening of the leaf canopy, shading the ground, and providing the main crop with a wind-firm ally at all dangerous points. The most useful of all trees for combining these qualities is beech. It adapts itself to various soils and situations. It can accommodate itself to the shade 
thrown by most species, and is sufficiently wind-firm to repel either persistent wind, or gales of arerage force. In addition to these qualities, it produces timber which can always be disposed of readily for some purpose or another, while it seldom requires replanting if ground game is kept under. The good qualities of beech in these respects is best seen when in company with oak or larch, and to a less extent with Scots pine. On dry soils or in dry climates it is doubtful if larch ever attains large dimensions except when the soil is kept moist and cool by beech humus and shade. Oak is drawn up straighter and cleaner, and its stem kept free of water branches when growing amongst beech. Scots pine is prevented from forming deep crowns, and the surface kept free of dry, musty humus and heathy ground vegetation by this tree better than any, and there are few dry-soil species which are not the better for a sprinkling of beech amongst them.

Continental foresters have recognised the value of beech for centuries, and have faroured it with the title of Wald-muitter, in virtue of its nursing qualities. In British forestry it has not been sufficiently appreciated so far, but the influence exercised by considerations of game cover has probably kept the beech from being more extensively used and systematically planted, even when its value has been clearly demonstrated and appreciated. Not merely can it assist the development of most species in the manner indicated, but the great advantage of an admixture of beech is seen when a wood is cleared and replanted. In place of a dense growth of grass, bracken, brambles, and other rubbish characteristic of open woods, beech gives a clean surface, and a valuable mulch of humus, beneath which the roots of young trees quickly establish themselves. In sinall woods this feature is of the greatest importance, and the cost of 
replanting might be reduced considerably in the future by a more plentiful use of beech.

For wind resistance the silver fir deserves special mention for exposed sites. This species probably reaches a greater height in the teeth of the wind than any other, and as it bears sea wind well it can be used where many species fail from the influence of salt alone. Its best results as a wind resister are seen when planted in belts or screens across the direction of the prevailing wind, and if these belts were formed on systematic lines, the production of timber on many exposed districts might be increased by 20 or 30 per cent, owing to the additional height growth alone, leaving out of account other favourable effects of shelter and immunity against wind damage.

In the drier and warmer soils or climates, Corsican pine may be included amongst wind-resisting species, using it for belts in the same way as silver fir. On soft or shallow ground it is liable to be blown over when ten or twelve feet in height, but if this stage is once passed the tree soon secures a firm hold of the soil, and if mixed with beech to thicken the canopy, a thick and permanent wind-break is formed.

In addition to these species, any deep-rooting, broadleaved tree, especially ash, oak, and sycamore, prevent extensive windfalls in coniferous woods, although they do not attain the height in the face of wind necessary to provide sufficient shelter for the leading shoots of other species. They are better adapted for the margins than for the interior of the woods, unless grown for their own sake as timber.

Temporary species adapted for early thinnings are chiefly represented by larch, which is the only pole timber readily saleable before the thirtieth or fortieth year. One-half to three-fourths of the timber originally 



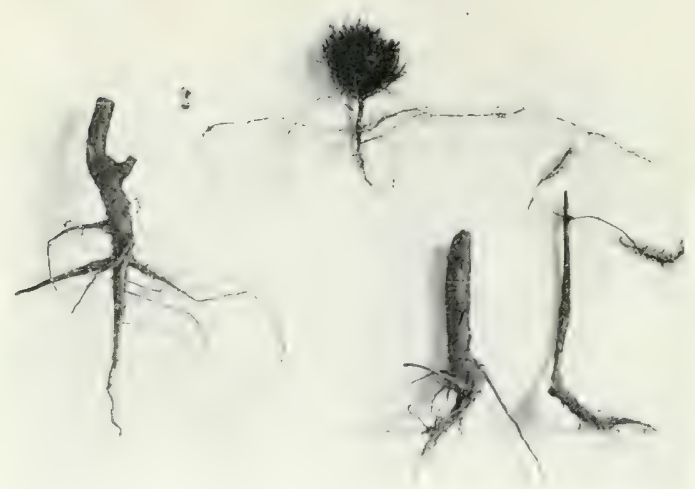

47. NatURAL AYM DISTORTEI ROOT SYSTEMS OF SCOTS PINE.

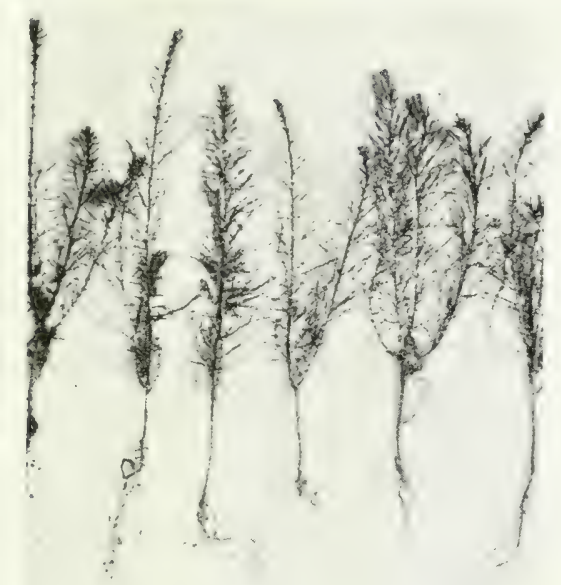

49. Two year Maritime Pines grown I. LEAF-MOULI-UNTRANSPLANTED.

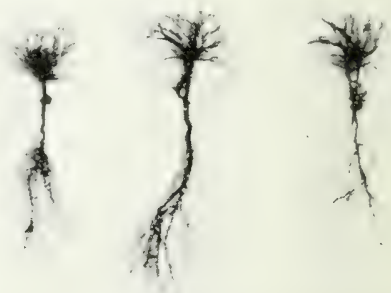

4S. (ИRーIC JIXE-TRANSILANTEI TWO YLAR

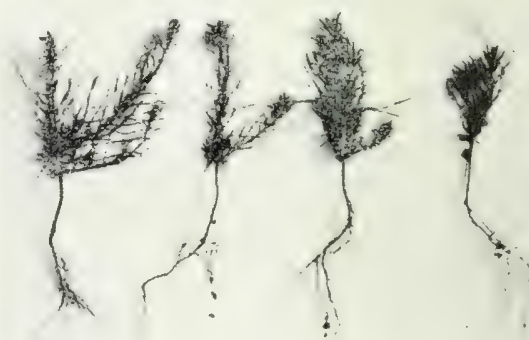

50. Maritime PINES. TWO YEAR SEedidygs —UNTRANSPLANTEI. 
planted in any crop may usually consist of this species, apart from hopeless soils or exposed situations. Bad results often arise from the use of larch in a mixture, owing to the fact that it is allowed to get ahead of the other species too far at first, leading to their partial suppression and weakening at a critical period. Larch, when mixed with slower growing species, should be freely pruned back during the first ten or fifteen years, and entirely removed by the twenty-fifth or thirtieth year, unless required for filling up gaps in the permanent crop.

Other trees of this class are ash, birch, Spanish chestnut, and spruce, all of which give saleable poles earlier than most species, and can be used in mixture with trees of an average, or rapid rate of growth. In exposed and windy districts, or on thin soils, however, it is rarely advisable to depend too much upon intermediate thinnings after the first twenty years or so. Any break in the leaf canopy after that age is a dangerous occurrence, and may lead to the destruction or stunting of the crop, unless extreme care is exercised.

The use of species for suppressing surface growth may or may not be necessary on ordinary soils, but on poor, peaty ground covered with heather, bracken, Vaccinium, etc., such species are desirable, if not absolutely necessary, to bring about satisfactory results, especially on exposed sites. One important feature of these species must always be cheapness, and ability to thrive under the existing conditions from the first, otherwise no advantage is gained in using them. The most suitable species for the worst classes of soils are birch and mountain pine, but the litter is, of course, useless for anything except firewood, and birch must be planted closely to produce the desired result. The system adopted in Jutland and elsewhere, of planting mountain pine and white American 
spruce in the form of a preliminary crop, has much to recommend it in unfavourable situations, and probably the $m$ re general arloption of this plin on doubtful soils would be as cheap in the long run as that of risking valuable or uncertain species, resulting in about three failures to one success.

In British forestry 'nurse' trees are usually conifers like larch, spruce, Scots pine, and others, which can be cheaply and successfully planted. The question naturally presents itself to the planter of mixed crops, or those in which nurses have to be used at first, Are these species the best that can be used for the purpose? Larch grows rapidly, and is valuable in most cases at the first thinning; spruce is cheap, easily transplanted, shades the ground well after a few years, and is worth something as a pole; Scots pine is cheap, easily transplanted, and proves perfectly hardy against late frosts. All these are valuable qualities in trees which have to be planted and afterwards cut out before they attain a profitable size, and a planter who uses Scots pine on dry, spruce on wet soils, and larch more or less everywhere for the purpose of nursing, is probably not very far wrong in most cases. But for rapidly growing species, like Douglas fir or Sitka spruce, these three species seldom start away quickly enough to keep pace with their charges. In some localities larch may not only grow as fast as Douglas fir or Sitka, but even faster, and in parts of Ireland. Douglas fir may occasionally be seen which has been partly suppressed by larch during the first twenty years. As a rule, however, Douglas fir rushes away after the fourth year and requires a quicker growing nurse than European larch. The same nay be said about the Sitka spruce, although this tree takes longer to start rapidly away than Douglas fir. For most species, especially broad-leaved trees, larch, spruce, or Scots pine 
grow quite fast enough, and occasionally too fast. With the exception of Scots pine they are, however, easily pruned back and kept in check, and with proper attention no serious injury should follow their use as nurses. Scots pine is, howerer, a more doubtful nurse tree, as its wide crown development, atter the first five or six years, often renders it objectionable.

Several other species than the above, however, might be mentioned which are not commonly considered as nurse trees, pure and simple. 'These are Japanese larch, Banks' pine, and mountain pine. The two former species are remarkable for their rapid growth when young, but the latter never attains a great height, and is chiefly valuable in suppressing a surface growth of heather or other troublesome plants not easily killed out. The objection to Japanese larch so far is that it is still too expensive to purchase on a large scale, but its ability to grow rapidly for a time in almost any soil will compensate for that drawback in the eyes of most planters. As a timber tree, the Japanese larch will probably prove a failure, though no one can say that this is yet certain. But for making a quick start, covering the ground rapidly, and producing a humus layer on the surface, it has few equals. Banks's pine has the merit of being a cheap tree, and also gets away rapidly on British soil. As a nurse for Corsican or Veymouth pine it might prove useful on poor soils, although it is perhaps not such an improvement on the Scots pine after all, and has little or no timber value. 'The chief value of mountain pine depends upon its soilshading qualities, and for this purpose it is largely used in Danish forestry. In Britain it is seldom planted on a systematic scale, but for heathy and peaty soils on exposed sites it is possible that the planting of this tree might have good results as a mixture with spruce, silver fir, and scots and Corsican pines, provided the latter are 
planted thickly enough to give a complete canopy by the twentieth or thirtieth year.
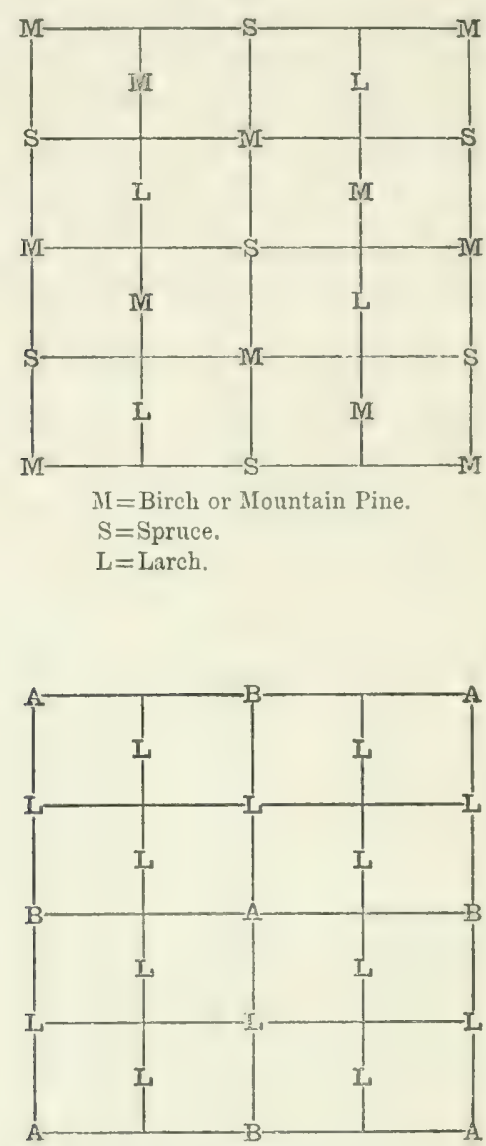

$\mathrm{A}=$ Pine, Larch, Oak, etc.

$\mathrm{B}=$ Beech or Spruce.

$\mathrm{L}=$ Larch.

DIAGRAM FOR TREE-PLANTING.

The question arises as to the minimum number of trees which must be planted per acre to attain the above 
objects of soil-shading and branch-suppression, and what proportion the nurses should bear to the main crop. The
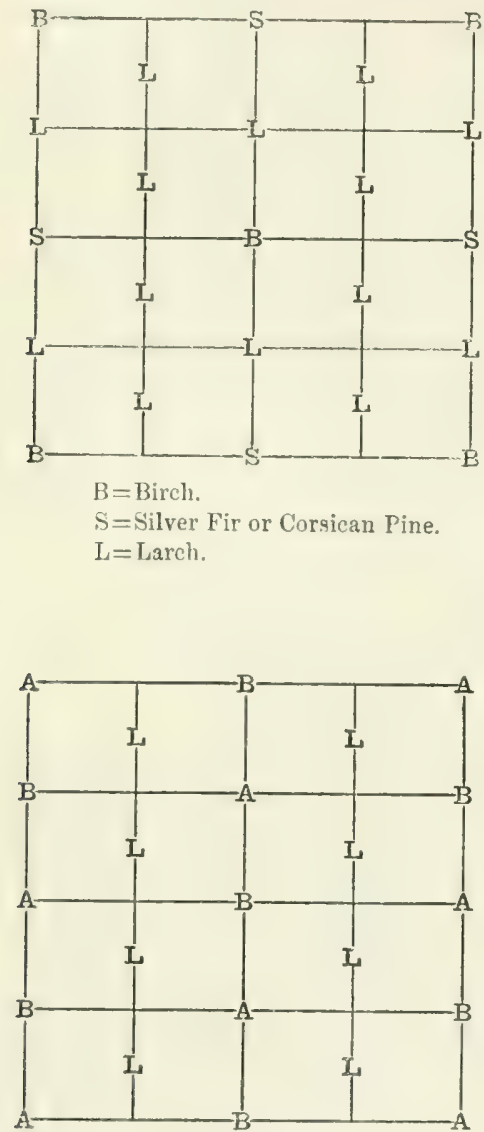

$A=$ Light-demanders

$\mathrm{B}=$ Shade-bearers.

$\mathrm{L}=$ Larch.

DIAGRAII FOR TREE-PLANTING.

number of trees put in per acre will determine the age or size at which a complete canopy is formed, or the 
stage at which the branches begin to interlace and become suppressed. In well-grown crops a complete canopy should be present when the trees are not more than ten feet in height, otherwise coarse timber will be produced. A full canopy before that height is reached can only be obtained by thick cropping, and it will usually be found that the adrantage of too great density at first is not sufficiently great to repay the expense, while certain disadvantages may occur.

The formation of a full canopy when the trees are not more than ten feet in height prevents the formation of large branches on the lower parts of the stem completely, whatever the species may be. In a general way very clean timber is produced when the branches are killed off when not more than half an inch in diameter; moderately clean timber when they are killed of at anything under an inch, and with complete soil-shading before the first ten feet of stem is formed, the latter size is not likely to be reached.

The density required for a full canopy at that height depends upon the habit or character of the species. Ash or sycamore, which grow rapidly in height as compared with their branch development, must be planted at one to two feet apart to produce a canopy at the height named. Scots pine, larch, spruce, etc., and the majority of conifers, owing to their more formal and pyramidal habit, close up when planted at four feet apart without difficulty by the time they have reached a height of ten to twelve feet. Continental foresters, producing woods from sowing or natural regeneration, are accustomed to crops of 20,000 to 50,000 or more plants per acre during the first ten to twenty years, and under these conditions a canopy is formed when the trees are two or three feet in height. This has the advantage of giving natural selection every chance, and of checking all surface 



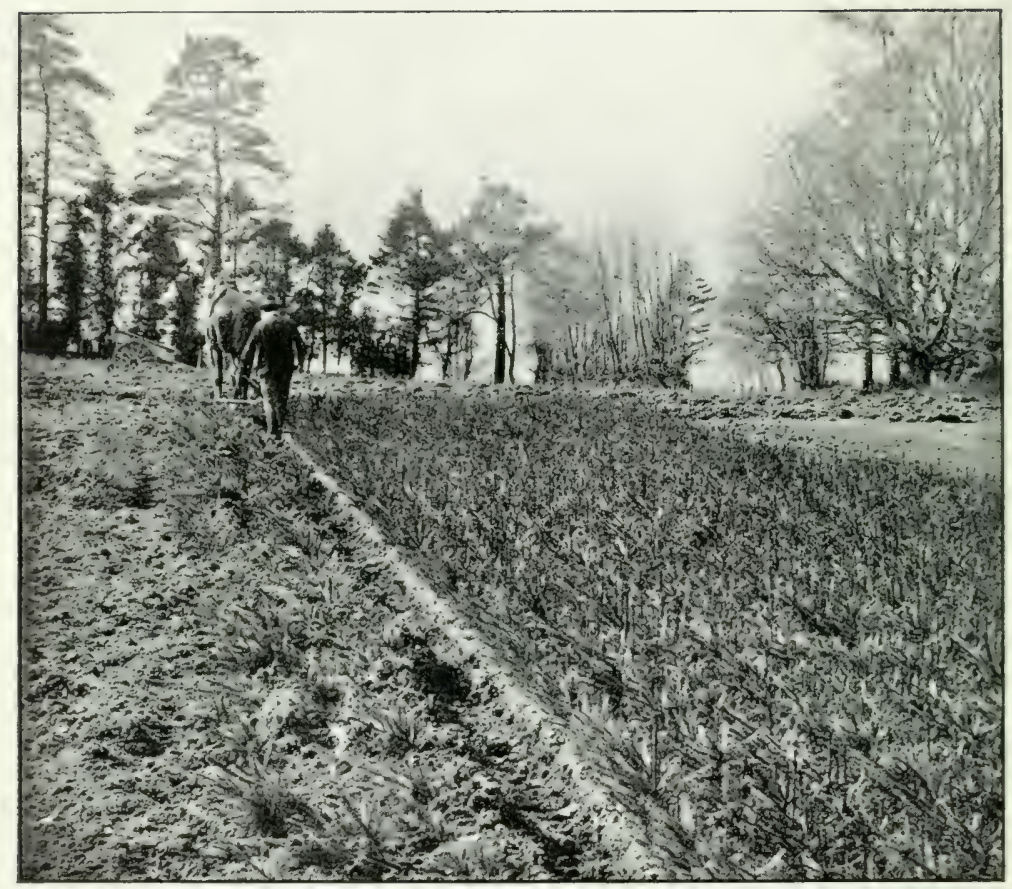

51. Liffixg: SpRUce with plough at Ambeyleis. 
growth likely to affect the trees in any way. But the custom of leaving crops of this kind alone for twenty to thirty years to tight out the struggle for supremacy is responsible for the great length of time they require to produce good timber. It is not uncommon to find beech, silver fir, spruce, etc., which have not increased more than four or five inches in diameter at thirty years of age, and the majority so greatly weakened in the struggle that the total number of vigorous trees left by the fiftieth year is less than would be found in a crop planted and thinned in the British fashion. This dense crowding during the early stages is not economical, although it may lead to the production of the finest timber in a few individual trees in the long run. As a matter of fact, German foresters are beginning to adopt the system of heavier and earlier thinning than was the practice twenty or thirty years back.

In planting four-year-old plants, the same or even wider distances are often adopted on the Continent than the three to four feet usual in Britain. Spruce in Belgium, for instance, is planted at six or more feet apart, a distance at which no British forester would plant on ordinary ground. Nuller, ${ }^{1}$ in reviewing the report of the Royal Commission on Coast Erosion, commented on the suggested planting of 3000 to 4000 plants per acre as a greater number than is customary in Germany. The cases in which thick planting is carried out are chiefly those where two-year seedlings are planted, or where bunch-planting is ardopted. Even with a stock of 10,000 or more plants per acre, however, the expense rarely exceeds $£ 5$ per acre, allowing for preparation of the soil by ploughing. On the Jutland heaths surface and subsoil ploughing, harrowing, and planting spruce and pine at the rate of 4000 to the acre amount to $£ 4$, and ordinary pit-planting costs rather less. In Belgium

${ }^{1}$ Zeitschrift für Forst-und Jagdwesen. April 1909. 
planting on peat, including draining and applying artificial manure on soil, can be done for $£ .5$ per acre, but the distances at which the trees are planted are very wide, six or seven feet by five feet, and these distances would scarcely give satisfactory results in Britain. Ordinary planting on the Continent rarely exceeds from $£ 2$ to $£ 3$ per acre, the reason being the low cost of plants as compared with the high price of transplanted trees in Britain, and the lower cost of efricient labour. Fencing and rabbit netting are seldom required, and work being done on a large scale reduces the cost of all operations. There is, therefore, no good precedent from continental forestry practice in increasing the already heavy cost of planting in Britain by the use of more than 4000 plants per acre at the most. With expensive species even a crop of more than 1000 trees per acre is rarely justifiable, although such wide planting may lead to coarse timber, unless careful pruning is carried out, or suitable nurses used for filling up. Herein lies the great advantage of using the species already named as nurses to broad-leaved trees, or expensive conifers, provided care is taken that they do not smother or unduly weaken the latter at a later stage.

The number of permanent species per acre, however, is a point upon which too little attention has been paid since mixed plantations became the fashion. The custom followed by nurserymen and the older planters is that of planting broad-leaved trees twelve feet apart, and in many cases these did not consist of one species but of several. Out of 2500 to 3000 plants per acre, therefore, the species best suited for arriving at maturity on the particular soil and situation may not have been represented by more than 100 or 200 plants per acre, allowing for deaths, accidents, damage by ground game, insects, and fungi. It was impossible to guarantee, under such conditions, at the 
end of fifty or sixty years a pure crop of more than two or three dozen well-developed trees per acre, the remainder consisting of sickly trees, nurses and other species, which might have no particular value in the first place, and could not give a satisfactory account of themselves in the second.

The above is one, if not the chief, cause of the bad material and financial yields from British, and especially English woods, apart from excessive thinning and other malpractices of a more or less deliberate nature. It can only be aroided by planting three or four times the number of the main crop species, or at least 700 to 1000 to the acre. This would represent about one-fourth of the entire crop planted, so that a pure wood may be found on the ground by the fiftieth or sixtieth year, according to the rate or degree of thinning followed.

In addition to the actual number of permanent species planted, again, special attention should be directed to their quality and early development. A custom has prevailed too long of the indiscriminate use of plants indifferently raised or treated in the nursery lines. There is almost as much difference between individuals of the same species, so far as rate of growth and general development are concerned, as between two individuals of different species. From the seed bed to the plantation, and cluring the first five years after planting, a process of selection should be carried out amongst the main crop species until the majority of these at any rate give every promise of satisfactory development at the tenth year or so of their existence. Ash, beech, sycamore, Douglas fir, Sitka spruce, poplar, etc., can all be safely transplanted at three to six feet in height, provided they have been properly treated in the nursery. To plant a large number of trees at this size is expensive, but 200 to 300 can at any rate be put in per acre during the first 
two or three years after the original planting, at a cost which need not exceed $£ 1$ to $£ 2$.

With good surface preparation and careful planting the filling up necessary after the first two years should not be great in any case, but barl seasons and difficult transplanters have much to do with the actual number required. The aim to be kept in view is that of having a healthy and uniformly distributed crop of at least 2000 plants on the ground at the end of five years, and if this is accomplished coarse timber need not be feared.

A common feature of British planting operations, and one which is perhaps less marked on the Continent, is tho large number of failures which occur with nearly all species. As a rule, bad transplanter's are not extensively grown abroad, and with ordinary precautions failures need not occur. Their prevalence in British forestry with ordinary species must be due, therefore, to peculiar circumstances which it is worth while considering, as these failures are one of the most discouraging features associated with British forestry.

The average percentage of failures in planting operations may be estimated at frow 25 to 50 per cent., and as the same species way be transplanted in the nursery with a loss of less than 5 per cent, the difference must be due to faulty methods somewhere. Years of exceptional drought and heat are, of course, responsible for many deaths in all cases and all countries, but these are easily understood. In ordinary seasons more than 10 to $20 \mathrm{per}$ cent. of losses should not occur if the work is properly carried out, and, as a matter of fact, failures in wellmanaged planting operations in Britain are much lower. The question is one of some importance, and especially so where plantations can only be protected against ground game for a limited period, and filling up cannot extend 
over the first two or three years. It is still more important when expensive species are being used.

To clearly understand transplanting failures or successes it is necessary to glance at the condition of various forms of regretation during the winter months. The resting stage of most plants is retermined by their inability to withstand certain climatic phases or conditions in a growing or actively functional state. Many bulbous plants, for instance, like the snowdrop, crocus, hyacinth, etc., or herbaceous plants of various kinds, remain dormant during the summer, and commence growth in midwinter or early spring, when woody plants are still dormant. Transplanting of these species must, therefore, be undertaken in autumn, unless special precantions are taken in moving them. Herbaceous pliunts generally commence growth in March and April, and can usually be moved safely until the shoots and leaves are developed, or attain a length of six inches or so, after which interference with the roots is injurious. The dormant condition of both the above types is characterised by the death of the portion above ground, as by such means their permanent organs are hest protected against drought and desiccation when the soil is frozen in winter, and the temperature too low for root action to proceed. The roots formed during the previous growing season also die back, and the vital part of the organism is limited to the base of the stem, or some modified form of stem or root.

Woody plants, on the other hand, which produce perennial or persistent parts alove gromud, have adopted special devices for withstanding cold whenever the winter temperature drops far below freezing point. With a few exceptions, all cold-climate plants are either deciduous or coniferous, and both these groups prepare for cold weather by ceasing growth in antumn, and forming winter buds at their growing points. This cessation of growth is also 
marked by a change in the physical structure and chemical constituents of the stem. The cell walls of the wood become hardened or lignified, and the cell sap denser and more sugary, both of which changes enable the shoots of the previous summer to withstand the greatest degree of cold, or the longest spell of cold, drying wind, normally borne by the species. When winter cold sets in before this process is completed the ends of the shoots, which are the least lignified portions, are either frost-bitten, or desiccated by wind at low temperatures, according to the prevailing conditions at the time.

Another feature of woody perennials is the extension or prolongation of their root systems, so that, in course of time, the extremities or growing points of the more vigorous roots are many feet distant from the collar or base of the stem. While a bulb or herbaceous plant, therefore, can be transplanted at ten or twenty years of age-assuming that it lives so long-as easily as it can at one or two years, the difficulty of transplanting woody plints increases with age, and can only be successfully accomplished when special methods are adopted, such as frequent tramsplanting, root-pruning, etc., so that living and functional roots are attached to the transplanted tree in sufficient numbers to maintain the transpiration current. The above facts are well known to any one who thinks of them. Many persons forget or do not take the trouble to remember them, however, and that must be the only apology for mentioning such elementary points here.

Successful transplanting may be said to depend in the first instance, therefore, upon the following conditions being fulfilled:-The shoots of the plant must be sufficiently well ripened to enable them to withstand the amount of desiccution to which they are subjected after 
the root tips are injured or destroyed, and until they are again renewed. In damp, well-sheltered spots, during mild winters, on warm soils conducive to rapid root formation, or in late spring or early autumn planting, this ripening of the shoot is of least importance, as the period and intensity of the drying process is shortened and reduced previous to the formation of new roots. This drying process is counteracted, under ordinary circumstances, by the cell walls being maintained in a saturated condition by the transpiration current. With the decrease of this current in winter, or its cessation owing to the disturbance or destruction of roots in transplanting, the loss of moisture cannot be made good, and death of the most exposed parts ensues unless the wood is thoroughly ripened, as thin-walled cells lose water more rapidly than those of well-ripened wood.

In well-sheltered places, evaporation and desiccation are reduced to the lowest point, mild winters are not productive of fatal temperatures, and warm soils are conducive to rapid root formation. In spring or autumn, or early and late planting, the work is done when the healing of broken roots is likely to be most rapid, and the plant has a greater chance of recovering. Certain species seldom or never ripen their wood sufticiently to render ordinary transplanting easy under two or three years of age. The worst in this respect are P'inus insignis, Pinus maritimu, Cupressus macrocarpa, and a few others of that class. The pines do not form winter buds at all the first season, and only imperfectly the second, while they are both rapid growers and poor rooters. With these species annual transplanting for the first two seasons, and planting them out finally in the third, usually gives the best results, taking care that all operations are carried out in October or April in each case, and that great care is cxercised in lifting and transplanting. Cupressus macro- 
'urpu, as with some other species of that genus, merely ceases its growth in autumn and resumes it in spring, and it is doubtful if any precautions are effective unless the trees are placed in sheltered situations. The difficulty with this species appears to be its rapid growth and barl root system, the latter consisting of a tap-root, and a scanty supply of fibres which are easily broken and damaged.

Crowding in the nursery is a frequent cause of badly ripened wood with many species. This crowding may take place in the seed bed or in the nursery lines, and in either case is conducive to long, drawn up, and weakly plants. Of the two, thick sowing is preferable to thick lining out, as the latter will weaken plants at a time when this is most objectionable, and when they need all the vigour and reserve strength possible at the time they are planted out. Thin seeding and lining out, of course, mean extra expense, and the nurseryman who tries to sell, or the forester who wishes to buy, trees at the minimum price per 1000 is neither likely to produce or plant trees which possess the good qualities necessary for successful work. Weakly plants are not only more liable to suffer from wind or frost during the winter, but they contain scanty stores of reserve material within their tissues to renew damaged or destroyed parts. When the growing points of the roots of such plants are injured or lost through transplanting, the formation of new roots proceeds on a very limited scale, and may, under unfarourable conditions, fail altogether. In the same way, the leaves and shoots pushed out by weakly plants are feeble organs of assimilation, and do little to carry on the growth of the plant for several weeks. In fact, nursery crowding is bad for all plants, whatever the species may be, and must be avoided if good trees are to be obtained. 


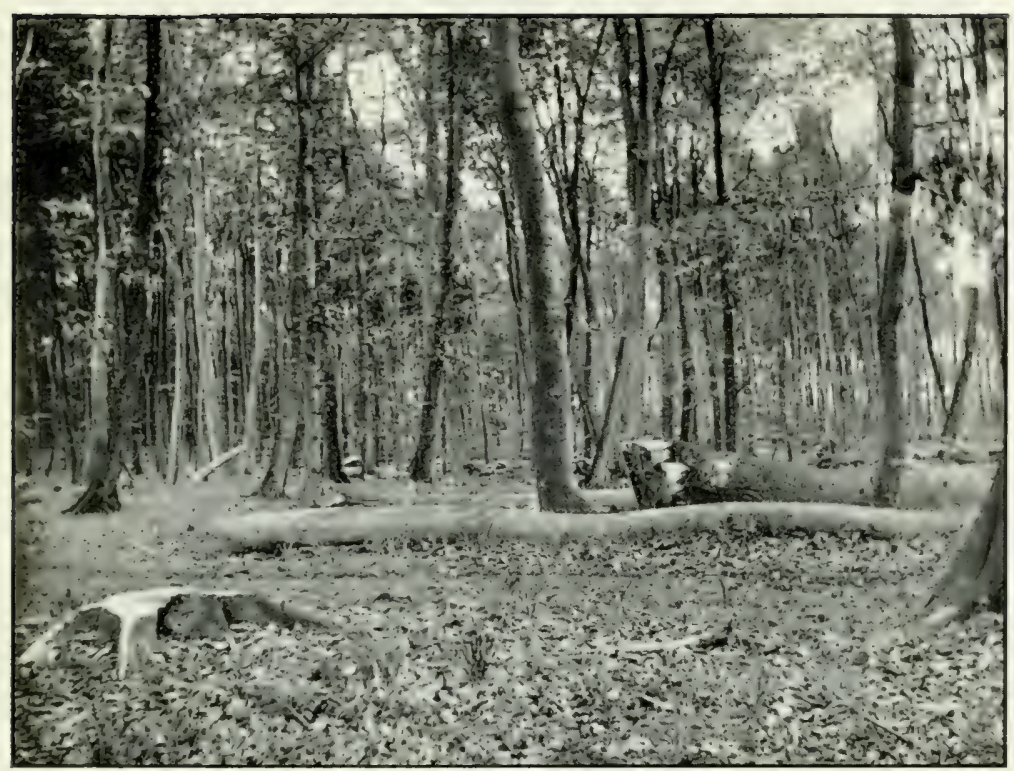

52. Selection feiling in Chiltern Hilds beech woOt.

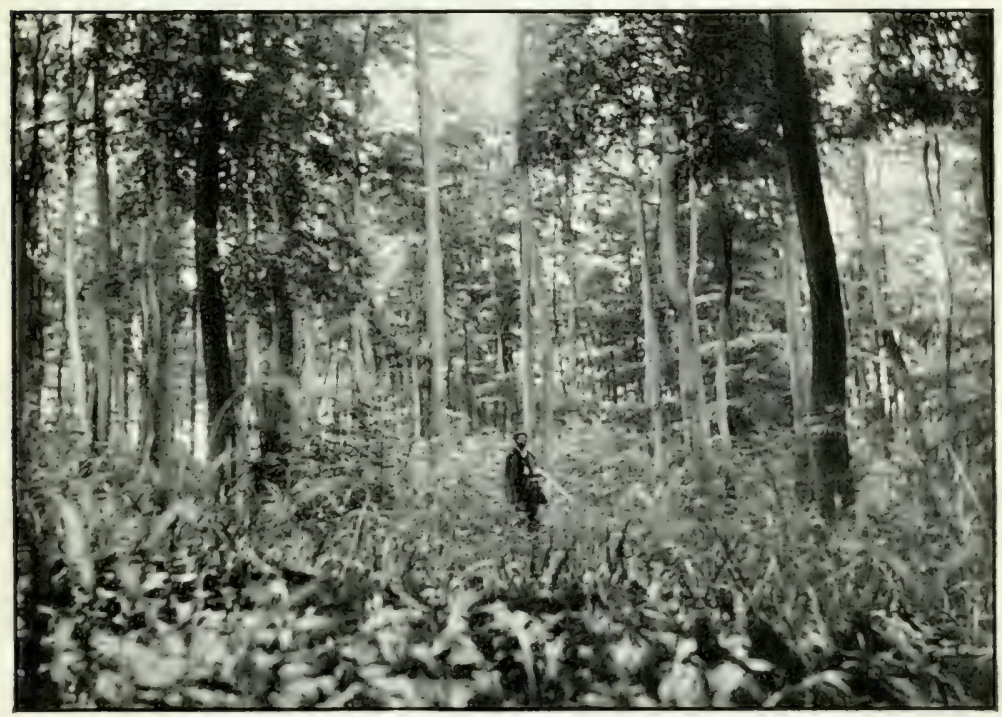

53. T'WO-STORILI) BHF(H WOOH, CHILTERN MILLS, 

Sufficient living and functional roots must be lifted with the plant to carry on the absorption of water from the soil. This condition varies in importance with the one first named. With well-ripened wood the plant is able to survive for a limited time, two or three weeks at the most, whether direct root action, other than the mere physical absorption of water by contact with damp soil, takes place or not. If new roots can be formed before any injurious desiccation has taken place, the life of the plant is assured, and growth, however slow, will go on. But if new roots are so long in forming, or the weather immediately after planting is so dry and warm that the above ground parts of the plant dry up in a week or two, death usually ensues. Failures of this kind are most likely to occur with species like Corsican pine, Austrian pine, oak, hickory, and others with long straggling roots, the ends of which are invariably torn or broken in lifting. In most cases of this kind no living root tips are moved with the plant at all.

Cold, wet soils also delay recovery from planting by checking healing and renewal of roots, and before the latter occurs the plant either dies altogether, as in the case of a conifer, or dies back to near the ground level if a deciduous tree. Occasionally Austrian and Corsican pines exhibit the power of remaining almost dormant for an entire season, the buds alone slightly lengthening, but the plants otherwise showing no signs of growth above ground.

Even in cases where living roots are lifted and transplanted, death often ensues with spring planting in dry and warm seasons, as the roots are not brought sufficiently into contact with the soil for them to carry on water absorption fast enough. Larch is a frequent sufferer from this cause, and it can only be avoided by atumn or early spring planting. 
Slit-platnting on rough or stony ground, or on thick turf, also leads to many deaths from this cause, as the roots are seldom surrounded by fine soil from which the newly formed root-hairs can at once take up moisture.

Careless lifting is, of course, chiefly responsible for the loss and injury of roots at transplanting. On stiff soils, and with the bad rooters already named, the lifting of more than a limited number of roots with their growing points attached is difficult, if not impossible. On light soils, and with ordinary species, however, loss of roots to an injurious extent is only the result of careless lifting. In the nursery, the method usually adopted is for one man to thrust a spade under a row of trees, and lever them up as far as possible, while another man catches the tops, and puts his whole weight upon them. The final result of this operation is that all growing points are left in the ground, the portions lifted are broken and torn, and if pines, probably skinned to within several inches of the collar. Plants lifted in this way do not always die, but it would probably be better if they did, for they linger on for two or three years in a sickly and stunted condition, and may suffer to such an extent from insects, rabbits, and fungi before they can recover that they remain stunted for years, and form an uneven and irregular crop.

Lack of frequent transplanting is also a cause of badly rooted trees, for strong tap or side roots are formed after the first year in the nursery bed, at the expense of fibrous roots near the collar. This is a well-known fact, and frequent transplanting is duly advertised by nurserymen, although they are not always so careful to supplement frequent transplanting by the equally important precaution of careful lifting and packing.

Removal from nursery to planting ground without allowing roots to dry is one, if not the most important, 
point of the whole process, when the nursery lies, as is often the case, a long distance off. The custom of bundling up trees into hundreds, packing them loosely into trucks, or possibly worse still, into transparent or perforated mats, in which they lie for two or three weeks, to be again taken out and laid in the ground, still tied up in bundles, is responsible for many failures. From the time they are lifted until finally planted out probably an interval of two or three months elapses, and during the whole of that time a process of drying is groing on, more or less rapidly, according to weather conditions and situation in which the trees are placed. With damp, gloomy weather, or when the trees are lying in a sheltered hollow, the process of drying out is delayed. Bright, frosty, or windy weather, on an exposed site, generally brings about the deaths of all but the hardiest trees, except those individuals which happen to lie in direct contact with the soil.

The remaining condition necessary for successful planting lies in survounding the roots with fine soil, and keeping the surface clear of weeds, grass, and other rubbish which deprive the tree roots of necessary moisture or smother the leaves and growing points. This involves some form of soil preparation in the majority of cases.

The preparation of the surface soil in Britain, before planting operations are carried out, is practically confined to the burning of heath, the cutting of gorse, broom, bracken, and woody growths of various kinds, or to the simple process of pit-planting. Very occasionally such operations as ploughing, paring, or grubbing out surface growth may be practised, but for obvious reasons the first named cannot be carried out on rocky or uneven ground, and the others are very expensive, and on that account are either neglected or badly performed.

Slit-planting is often the only method adopted over 
wide areas, and cheilp and efficient as this method may be under favourable conditions, it is not, and never can be suitable for planting on more than a limited proportion of the soils of the British Isles, unless some previous preparation of the surface, other than that mentioned above, has been carried out. The essential features of slit-planting implies the existence of a skin of turf, peat, or some other covering of vegetable origin which binds the surface soil together. Without this skin, slitting in the ordinary way is scarcely practicable, and pitting, notching, or dibbling are the only methods of getting trees into the ground. The success of slit-planting depends very largely upon the depth of the turf and the condition of the soil below. Where the peat, roots of grass, rushes, bracken, or other growth is more than an inch or two in depth, and forms a thick blanket on the surface of the soil more or less impervious to showers and the free circulation of air into the soil, it is impossible for the roots of small trees to be brought into contact with finely pulverised soil, and so given such conditions as enable them to make a fair recovery from the injuries to their root systems, and the interruptions of normal functions which accompany transplanting. To the absence of such conditions must be attributed a rery large proportion of the deaths which follow slitting in dry or unfavourable seasons.

Hard subsoils, such as gravels, sands, etc., cemented into a concrete-like substance, must be broken up if slitplanting is to be successfully carried on, especially if iron pan exists in any form. The condition of the soil below the peat or turf, again, determines the result of slitting almost as much as the surface. Hard or plastic clays, and soils so stony or compacted that a spade cannot easily be got into them, are unsuitable subjects for slitting. In the former, the roots are alternately 
waterlogged in wet weather, and separated from the soil altogether in dry seasons, when the clay cracks and opens up in such a manner that the trees practically hang by the collars. The alternate swelling and shrinking of clay soils are extremely injurious to root action, and check formation of new roots in recently transplanted trees to a very great extent.

Of late years an objection to slitting has been raised on the ground that the bending of the roots, which is more or less associated with the method, affects the derelopment of the trees in after life. Plausible as this theory is, it does not appear to be supported from careful observation, apart from one or two species, Scots pine in particular. Eren with these, the results are not seen for two or three years after planting. But with practically all other species slit-planting, considered as a method of getting the trees into the ground, is quite as satisfactory as any other, and failures are chiefly due to causes already referred to. This is easily seen when one considers that root twisting and bending are quite as common in the nursery as in planting, and yet the percentage of deaths in nursery work is reduced to a minimum, not because the trees are more carefully planted, but on account of the fact that the roots are surrounded by finely divided soil, from which the newly made rootlets can take up water without difficulty. This latter condition may be regarded as a fundamental feature of success in all planting work, and whatever form soil preparation, or the insertion of the trees into the ground may take, the object to be aimed at is leaving the roots with as much fine earth in contact with them as possible. This point, of late years at least, has not been sufficiently attender to by British planters, and attempts to get the work done as cheaply as possible have not encouraged the adoption of more satisfactory methods. 
Planting at suitable seasons of the year. It is not easy to define a suitable season for planting every species, under all conditions of soil and climate. With species subject to rapid drying of buds and shoots, and furnished with bad root systems, planting in midwinter, or before cold, dry spells, invariably leads to many failures, hut it is not possible for the forester to anticipate the coming weather, and a great deal has to be left to good fortune. If every month in the year lived up to its reputation, the end of October or beginning of November for dry soils, and the end of March for wet, would be the most suitable planting periods for all species generally. At the former period soil water and atmospheric moisture are usually most abundant, and enable the trees to recover their normal conditions before cold weather sets in. In April frequent showers and a rising temperature farour root action, and the period of stagnation is short. All badly rooted trees, or those which possess badly ripened shoots, and coniferous trees generally, should always be moved at one or the other of these seasons, while deciduous species generally may be planted safely at any time between October and May.

The remedies for the above evils are self-evident and need little describing. Both more time and more money must be spent in nursery, soil preparation, and planting work if better results are to be obtained. Seed beds should be thinly sown, so that each seedling may have sufficient space to grow into a thick, stocky plant. In nursery lines, at least from three to six inches should separate the plants, according to species, larch especially requiring abundant space, if good plants are to be produced.

In lifting, the soil should be removed from the front of the plants and below them before the spade is put in behind them, and thoroughly loosened before pulling them 
out. A plan adopted by Mr. Havelock of Brocklesby, Mr. MIGregor at Abbeyleix, and others, of ploughing out the plants is an excellent one for avoiding unnecessary danger in this respect, provided reasonable care is taken to prevent injury to the tops. The soil containing the roots is turned over in a body, and a little loosening with a spado or fork separates the roots without violence being applied. With deep-rooting plants, like oak or Spanish chestnut, it might not be so suitable, but with the majority of conifers it is both cheaper and better than the brutal method described above.

Packing for transit could be improved upon by puddling the roots in clay as soon as they are lifted. This operation prevents the drying of the roots during the short exposures to the sun or wind which are inevitable at times. The clay film round the roots also absorbs moisture again readily when the latter are again planted or laid in, and in most cases prevents injurious evaporation of moisture, due to frosty weather in winter and spring.

In sending plants long distances by train, and when they can be packed and the journey completed in the same truck, it is probably better to use no packing beyond moss or straw in the bottom, and placing the bundles closely together with the roots downwards, or facing each other. Where more than one layer of plants is put in, straw or moss should be placed between them, and the second layer put in as before. This method prevents such a free circulation of air through the roots as when the bundles are thrown in indiscriminately, or as is the case when they are tied up in mats or bags through which the wind freely passes. Where trans-shipping is inevitable it is, of course, impossible to avoid the latter method. 
With smaller plants, or two-year seedlings, the packing adopted by continental nurserymen is the best. The plants are carefully packed into open crates with moss or other material round tho roots, and the top of the crate covered in with canvas. Plants when packed in this way can travel for a month without injury, and it constitutes the only satisfactory method of packing seedlings.

'Sheughing' or laying in the plants either in nursery or temporary depots before planting out should be carefully done, and if they are to remain for more than a week or ten days the bundles should be untied, and the plants opened out, so that all roots are brought into contact with the soil.

In planting, it matters little what method is adopted, provided that the roots are brought into close contact with fine soil, and the ground trodden firmly enough to maintain capillarity and prevent undue aeration. This usually means some form of surface preparation, an operation seldom performed in Great Britain. Under ordinary circumstances pit-planting usually gives satisfactory results, for the simple reason that the finer soil taken out of the pit can be used for placing on the roots, whereas in slit-planting the roots have to take their chance of coming into contact with soil, roots, stones, or any other material that may happen to lie on the spot in which they are placed.

Slit-planting is sometimes condemned, as already stated, on account of the twisting or bending of the roots with which it is accompanied. This bending, however, in itself will not prevent trees from growing, nor does it do any permanent injury to any species except pines. To the latter, and especially Scots pine, Weymouth pine, and other fibrous-rooted species, it appears to leave bad or even fatal effects for many years, owing to the difficulty 
these species have in replacing the bent or twisted roots by others of a normal habit of growth. The absence of fine soil, a matted surface, and the difficulty of firmly treading in the plant are more often causes of failure from slit-planting than any twisting or bending which occur's with the roots.

For small plants the dibbling or notching method in prepared spots is the most successful method. Circles from two to three feet in cliameter should be skimmed over with a broad-faced mattock, and the soil pickerl or loosened up to a depth of one to two feet. This produces a bed of loose earth, in which small plants can be dibbled in as easily as on a dug or ploughed surface; the only difficulty being the frequency with which the plants are thrown out by frost on loose soil, but in spring planting this is largely avoided. The expense of notching on this system is, however, fairly high-at least double that of slit-planting-but the results are very much more satisfactory.

Slitting is only suitable for loose, friable soils, which do not puddle when trodden in wet weather, are tolerably free from stones, and have a thin surface growth of heather, or fine grass, which does not form a thick, matted turf. Such conditions may be brought about occasionally by ploughing the surface, putting in a crop of oats, rye, or other cereal, and slitting in the plants the following season. Or another cheap method is that of taking out a deep furrow with the plough, placing the plants at regular distances in this furrow, and turning back the sod into its former position. But these forms of preparation for planting are not possible on a large scale, for it seldom falls to the lot of the forester to plant arable or pasture land of this class.

Experienced planters, however, have always maintained that pit-planting, all things considered, is the 
cheapest method to adopt, and the reason is not far to seek. In taking out the pit the soil is stirred and pulverised, and when the finer particles are placed in contact with the roots, as they should be, the conditions approach those prevailing, to some extent, in cultirated land. In stiff clays or tough peat, pitting alone may be insufficient to bring the soil into a fit condition. In the former, the soil must not only be broken up, but exposed to the air and frost, so that the capillary water of the clay may be replaced by air, and the whole reduced to a friable mass. The usual method adopted to bring about weathering is hole-digging in autumn, leaving the holes during the winter, and planting in spring. Many foresters object to this method on account of the holes filling with water, and preventing planting until late spring. To aroid this it is possibly better to dig the holes during the summer and plant in early autumn, before the soil becomes too wet and sticky. With conifers, however, autumn planting in such soils is a risky business, as the temperature of the soil quickly falls to, and remains at a point which is not conducive to root action or growth, and diminished aeration also acts in a similar direction. Observations on tree roots planted on wet soils in autumn or midwinter invariably show the death and decay of broken or bruised roots to a considerable distance beyond the points of injury. Conifers or evergreens, the leaves or needles of which transpire more or less during the winter, or from which evaporation takes place in windy weather, undoubtedly suffer from such soil conditions, and show a high deathrate from autumn or winter planting. Most planters, therefore, do not plant on wet soils until spring, believing that the short interval between the process of planting and the resumption of functional and regetative actirity in the roots reduces the risk of failure. In fairly damp 
and warm springs the results are usually up to expectation, new roots being formed quickly enough to bring the plant into its normal condition before serious damage from dry air or hot sun has been done. In dry, warm springs, on the other hand, the percentage of failures is usually heavy on clay soils, whatever the method of planting may hare been. These soils quickly crick and become caked on the surface, and the difficulty of inducing the roots to resume their normal function is greatly increased.

On tough, peaty surfaces the holing process is also insufficient to produce the required conditions, and for much the same reason. Peat, in its more or less solidified or compressed form, is not only retentive of moisture, but is cumparatively impervious to it, and resembles clay in many respects. When once saturated it holds water longer than ordinary soils. When once dry it takes up water again more slowly. On the dry gravels and heaths of the south of England in thin skin of dry peat which has formed muder heather sooner or later produces a waterlogged surfice in winter, and on mountain slopes with a fall too great to allow stagnation or accumulation of water a peaty surface is invariably saturated. The chief fault with peat, from a physical point of riew, lies in its being either too wet or too dry throughout the greater part of the year, except in very wet climates, when constant saturation is its normal condition. It is, as a rule, too tough and fibrous to allow air or roots to pass into it freely, and to render it suitable for growth of the ordinary plants, peat must be broken up and pulverised to a depth of one to two feet at the least, and on the class of soil now in view, this will usually enable the natural soil to be reached, and the plants to be put in under better conditions. With constantly saturated peat slit-planting often succeeds so far as the life of the plants 


\section{$18 \pm$ THE DEVELOPMENT OF BRITISH FORESTRY}

during the first year or two is concerned, provided they are able to stand the acidity peculiar to peaty soils. But the ultimate development of most plants when slitted into tough peat is very poor, and the results do not lead to anything of a satisfactory nature.

On thick grassy surfaces slitting is also an unsatisfactury method in dry climates, or with certain species. Mr. Spencer Pickering of Woburn believes that the bar success of many trees planted in grass cannot be accounted for by lack of moisture. But as the trees which do best when slitted in grass are usually those which do best on dry soils, or in dry climates, it is difficult to account for the failure of most species in any other way. S'cots pine, Corsican pine, birch, beech, etc., are the most likely to succeed when slitted or planted in grass, while ash, poplar, willow, etc., invariably do badly. In dry summers and dry soils, again, the failures on grass are very heavy compared with those in wet seasons or damp spots, and especially so with shallow rooters, such as larch, spruce, etc.

Moreover, the bad effects of grass invariably disappear as the tree roots get benenth the turf, and down upon the soil for their moisture. Park and hedgerow trees do not show any bad effects from grass, although practically all their feeding roots must be below it, and there does not appear to be any good reason for attributing the bad growth of grass-covered trees to any other cause than the one assigned above.

To avoid failures, however, grass and surface growth of any kind should be broken up or skinned off if possible. On the Continent, various implements are used for preparing the surface of old woodland, or ground containing roots or stones. The simplest is the forest plough, a heavy implement with double mouldboard and powerful share and sole, capable of cutting through roots two or 
three inches in diameter when worked by four horses. This plough leaves a wide shallow furrow behind it, from which all turf and surface growth is cleared, and in which the seeds or seedlings are sown or notched. Other forms of ploughs have a single mouldboard, and are designed to cultivate or turn over the surface more thoroughly. They require more motive power than the one described above, but otherwise are much the same in principle.

More specialised than these are the number of implements used extensively for working surfaces which cannot be ploughed on account of stones or stumps. These take the forms of revolving picks or grubbers, which tear up the surface to a depth of six to twelve inches, and do away with any skin of turf or humus which may have formed. Implements of this kind might well be used on many peaty soils in Britain, but on surfaces covered with boulders, or very uneven ground, difficulties would arise to prevent their extensive use.

If the precautions named above were taken, failures in forest-planting would probably be few and far between. The question of importance to the practical man is, can they be adopted without raising the cost of planting to a much higher figure than that at which it now stands? Probably they could not, but many of the advantages gained by the more costly methods described might be more cheaply secured by the universal establishment of home or temporary nurseries, in which trees could be grown for one or two seasons before being finally planted out.

On most large estates the home nursery is a recognised institution at the present time. But the form of it suggested here is a much simpler affair, which it is fairly certain would remove many of the risks incidental to planting, at the minimum of expense. At the present time the objections to the home nursery are sometimes

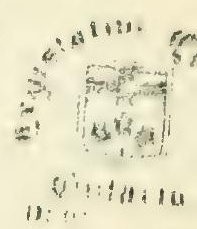




\section{THE DEVELOPMEN'T OF BRTTISH FORESTRY}

well founded. Laid out on an elaborate scale with clipped hedges, gravelled walks, and various other ornamental features, it has either to be cultivated entirely by spade labour at great expense, or what is more usual, becomes a series of patches of weeds and rubbish, intermixed with breaks of trees, berls of potatoes or roots, and various other mixtures which neither make for ornament, utility, nor economy. While a permanent nursery on a large estate is a llesirable feature in many ways, it should, in most cases, be no larger than can be kept in good order at moderate expense, and there can then be few objections to it. But the form of nursery of greatest benefit in large planting operations is that which consists of a corner of a field, or of the land to be planted, in which trees purchised from a distance can be lined out for one, or at the most two years before they are finally set out. In such nurseries economy in labour may be obtained through a liberal use of the plough in making single furrows, as deep as possible, about one foot apart, and placing the trees in these with or without deepening them with the spade, according to the condition of the soil. Where the trees are to stand for one year only, and with some fastgrowing species this is quite long enough, this furrow system of lining out answers admirably, and little or no cleaning or hoeing is necessary the following summer. The plants thus treated recover from the process of removing, make short, well-ripened shoots, become accustomed to the local soil and climate, and can be permanently planted the following year without requiring to be out of the ground for more than a few hours. The cost of bedding them out in this manner is slight, $2 \mathrm{~s}$. to $3 \mathrm{~s}$. per 1000 at the outside, while the risk of failures is reduced from 20 to 30 per cent. to not more than 5 per cent., provided reasonable precautions are taken in other respects. At present this style of nursery is chietly 
employed for holding surplus plants at the end of the season, and which come in for filling up blanks the following year. It should, however, be more universally employed for all bad transplanters, and in all cases in which doubtful ground or unfarourable sites have to be planted, forming an intermediate stage between the public nursery and the plantation.

\section{Suitable Srstems}

At the present time there are three fairly distinct systems in operation in the British Isles: even-ayed high furest, coppice with stundurds, and the system of selection fellings or uneren-aygd high furest, which is worlied more often to suit the convenience of the owner than in the interests of good forestry.

The first named is practically the only sound system to adopt where returns in the shape of high-class timber are expected. Coppice with stanclards is practically obsolete as a profitable system, while uneven-aged wouls. although capable of giving very high returns under skilful management and on good soils and situations, invariably degenerate under ordinary management into a policy of taking as much out of, and putting as little into, the woods as possible, resulting eventually in their exhaustion and depreciation.

But while the high forest can alone satisfy modern requirements in timber and money, coppice with stindards may be still retained under special circumstances, as where game cover is a primary considerition, or a special class of timber is wanted. Selection fellings, again, are well adapted for ornamental woodlands in which clearings might be objected to on æsthetic grounds.

But, apart from such cases, economically managed woods must be worked on a system which enables the greatest 
quantity of clean timber to be grown in the least time and the easiest possible manner, and this can only be accomplished by growing trees in even-aged masses, so that competition for light will do the work which would otherwise require skill and labour on the part of the forester. 'The urgent demands of the future will be for timber which can be converted at the least expense, and with the least possible waste, into saleable products, and the longer and cleaner the stem produced the more likely is this to be the case. Plantations 1nust, therefore, be formed and grown in such a way that the minimum of labour is required in their production from the time of planting until remunerative thinnings are possible.

Coppice with standards cannot produce high-class timber in large quantities, because the system favours the perfect development of a few individuals at the expense of the majority, rather than leading to uniform quality throughout. Whatever its merits may be under certain circumstances, it is no longer adapted for British conditions, unless the nary is to revert to wooden ships, hurdles and wickerwork are to take the places of wire and iron, and poles, bark, and other minor forest products regain their old values in Britain.

The selection system, again, is quite unsuited for exposed districts, in which the height growth of trees is none too great, even when grown in close order. In sheltered localities and good soils it gives better results, but not sufficiently good to yield an adequate return for the trouble of managing woods worked by it. In the case of first-class ash ground this system might be used with that species, but this is probably the only instance in which it could be justified as a commercial system at the present day.

From whatever point of view the various sylvicultural systems are studied it becomes evident that even-aged 
high forest can alone give a high yield of tirst-class commercial timber, and that little or nothing is gained by introducing or perpetuating troublesome or obsolete systems which have repeatedly proved themselves to be financial failures under existing conditions in this country. The most desirable form in which even-aged high forest should be worked greatly depends upon species and localities, but the one-storeyed form is best suited for probably 90 per cent. of British woodlands. Two-storeyed woods resulting from underplanting are seldom protitable, owing to the great expense involved in protecting the second crop against ground game. Where this expense can be avoided it is doubtful if much is gained by this system, except in the case of larch. With this species a heavy thinning at twenty to forty years of age may remore blistered trees, and favour the recovery of the remainder, and in such cases underplanting is a necessity. This system has been extensively followed by Mr. Munro-Fergruson, and several wood managers, but how far it could be repeated generally is an open question. In exposed localities, free thinning after a complete canopy is formed is a dangerous operation, and may lead to the blowing down or stunting of the main crop. If thinning is too moderate the success of the second crop is affected, and little benefit may be derived from it. Beech, silver fir, and one or two other good shade-bearers may succeed, however, under a fairly thick larch canopy, and on soils likely to bring larch to maturity the plan has a fair chance of success, and is particularly beneficial on dry soils. As, however, practically all the advantages of underplanting can be secured by suitable mixtures, it will probably remain one of those doubtful practices in British forestry which most foresters will leave to text-books and demonstration areas.

After all that can be said for or against any particular 
system, therefore, one is forced to the conclusion that even-aged high forest, formed of suitable mixtures or occasionally of pure crops, rarying with soil and situation, must be the practice generally followed, and the lines on which the woods of the future must be worked. This means that the practice of the last fifty years need only be modified in detail to bring it up to the required standard. The majority of systems, when reduced to everyday language, simply consist in planting the right trees on the proper soils and situations, and producings the greatest quantity of saleable timber at the least expense to the grower. 'This can only be done by intelligent treatment and personal care on the part of the forester, and not by any slavish adherence to stereotyped methods and formulie. Judicious planting, careful thinning, and a choice of a good time for marketing the timber are the essential virtues for any system, and without them none is a success. 


\section{CHAPTER VII}

THE ECONOMIC VALUE OF THE BRITISH FOREST FLORA.

A PRofitable timber tree is not easy to define in the abstract. A tree may be highly profitable when grown in certain soils or situations or under certain economic conditions, while the same species may be unprofitable when grown under different circumstances. With planted timber, the return necessary to render a tree profitable must be higher than in the case of trees which have been produced without artificial assistance from the seed of a former crop, or other means of propagation. I tree, again, which is regarded as profitable to-day may prove to be unprofitable in the course of fifty or a hundred years, owing to changes in manufactures or substitutes being found for its wood.

Instances of all the above cases may be found in the British Isles. Scots pine at low or moderate elevations in the Highlands of Scotland may be as profitable as any species capable of growing in the poor soils or raw climate of the country, owing to the cheap rate at which it can be planted. On rich soils and low-lying situations in many parts of England the same tree can scarcely be given away, unless grown near a colliery. Beech planted at any distance from a manufacturing centre can seldom be grown at a protit, while in the Chiltern Hills natural regeneration, combined with a local market, render it one of the most profitable crops that can be grown in the district. Oak affords a very good instance of a timber that once commanded a 
high price, and was extensively planted for shipbuilding. Now it is impossible to grow it with any prospect of profit on the majority of soils.

It may be assumed that no tree can be called profitable which is incapable of producing a volume of timber per acre per annum which exceeds in value the interest on the accumulated cost of production, allowing interest on all outlay at a rate which compares farourably with that yielded by any safe investment. Species requiring very rich soils or favourable situations, or a heavy expenditure to establish them on a sylvicultural scale, must be comparatively rapid growers in the first place, and command a good price per cubic foot in the second, before a nett return can be expected. With slow growers, or species which can only produce a low yield per acre, the returns are not merely sinall in volume, but the cost of handling. and marketing the timber is much heavier than in the case of a dense and heavy crop. A self-sown crop scattered over a wide area may be less profitable on this account than a heavy crop produced at much greater cost per acre, but commanding a still relatively higher price on account of its heavy yield on a small area. This fact is chietly responsible for the sowing and planting of Scots pine in Germany in place of the older method of natural regeneration, which, while successful in a general way, produced more patchy and irregular crops.

While. therefore, the characteristics which render timber species profitable in the British Isles are various, they are in a general way associated with one or all of the following features:-

1. Plentiful seed production.

2. Adaptability for transplanting, sowing in situ, or natural regeneration.

3. Power of resisting drought, early or late frost, wind, insects, and fungi. 
4. Rapid rate of growth on comparatively poor soil.

5. High quality or specific value of timber.

It will perhaps be difficult to find any one species possessing all the above characteristics, but it is obvious that no species can be termed profitable which does not exhibit two or three of them.

1. Plentiful seed production is an important feature in any species, but is especially desirable in one which requires to be grown on a large scale to create a market for its timber. With scanty or irregular seed supplies the cost of young plants increases, and may even be prohibitive. Many introductions from North America, Japan, etc., might be profitably grown in this country were it not for the cost and trouble of collecting their seed. Douglas fir, Japanese larch, Abies grandis, etc., are instances of species which occasionally fail to produce crops, while Pinus monticola, Larix occidentalis, and others are almost impossible to obtain on account of scarcity of seed. It is evident that no species can be cheaply and extensively planted which cannot be obtained in public nurseries, at a size fit to plant out, for from 20s. to 40 s. per 1000 -as, allowing for failures and subsequent replacements, at least 1000 plants per acre must be planted, exclusive of nurses, if a satisfactory crop of any one species is to be obtained. With a plant bill of more than $£ 4$ per acre, a species must be a very rapid grower, therefore, to show a satisfactory return at the end of sixty or eighty years, and it is only occasionally that one is found to do what is required.

The surest and heaviest seed producers in Britain at intervals of three to five year's are Scots pine, wych elm, sycamore, ash, beech, oak, birch, and alder. Amongst other species hardy in Britain, larch, spruce, silver fir, Abies nobilis, Douglas fir, Corsican and Austrian pines, maritine and Weymouth pines, all produce moderate 


\section{THE DEVELOPMENT OF BRITISH FORESTRY}

quantities of seed, but seldom enough to meet the requirements of nurserymen, and most of these seeds are imported. In the south of England, Spanish chestnut is usually a good seed bearer in certain seasons, and the same nay be stated of walnut, Robinia, and a few other species of minor importance.

2. Adaptability for transplanting, sowing in situ, or natural regeneration.

The ease with which a tree can be established upon the site of a plantation is an important factor in cheap timber production. With expensive planting methods, or the necessity for tilling up numerous blanks, perhaps two or three years in succession, the cost of planting increases rapidly, and from 30 to 100 per cent. on the original expense may be incurred before the crop can be considered satisfactorily establisher. While an average

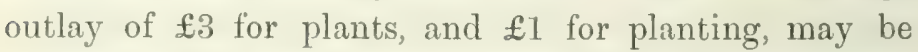
expected with good transplanters, difficult species may necessitate an expenditure of $\mathfrak{£} 6$ to $£ 8$ at the least, according to the season and number per acre planted. This probably means a total cost of over $£ 10$ per acre, and few species can be profitable at that figure on a long rotation. The easiest of all trees to transplant safely are spruce, Scots pine, Douglas fir, and lareh, amongst conifers, provided they are not more than one to two feet in height, and have been properly treated in the nursery. Easily transplanted broad-leaved trees are poplar, willow, alder, birch, ash, sycamore, etc., while broad-leaved trees in general give comparatively little trouble as compared with many species of conifers.

The most difficult transplanters amongst ordinary species are probably maritime and Corsican pines, but reference is made elsewhere to the necessity for special precautions being taken with these trees.

Species which can be sown in situ on soils and situa- 


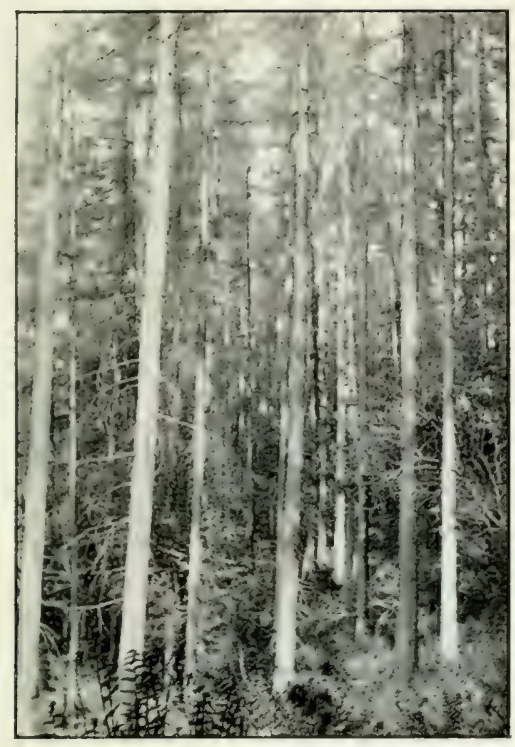

54. PURE LARCH WOOI). NORTHUMIERIANI).

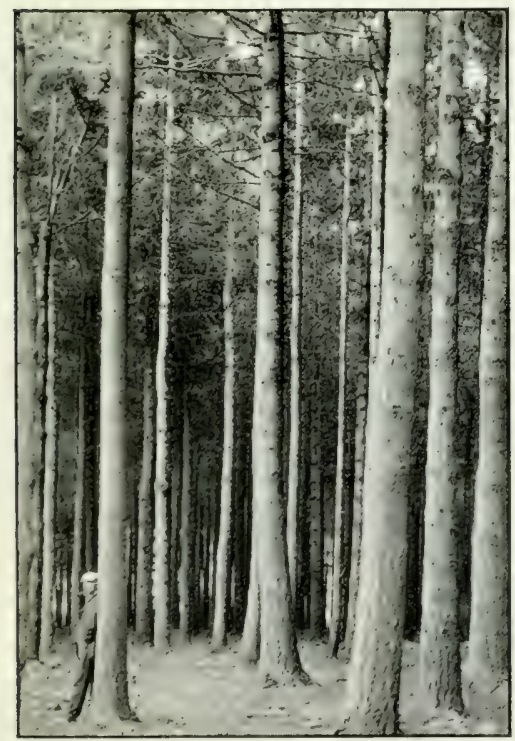

Photo by llewe HI. Mucude.

56. DOUCHAS FIR AT TAYMOUNT.

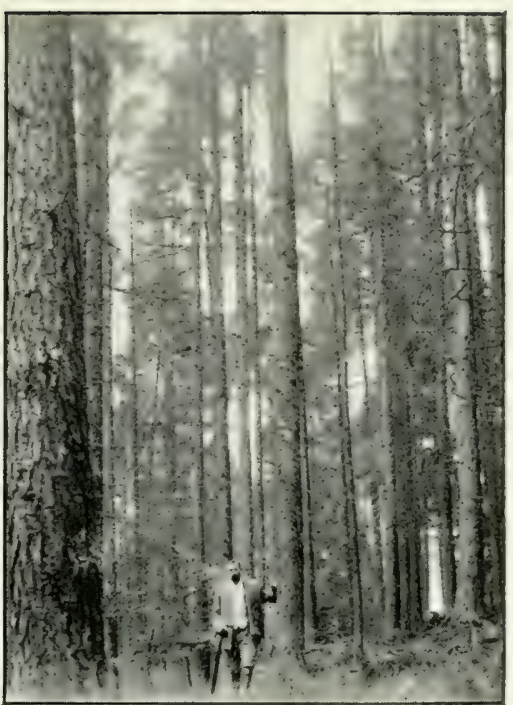

55. PURE IARCH WOOI).

WEST HIG:II,AYISS.

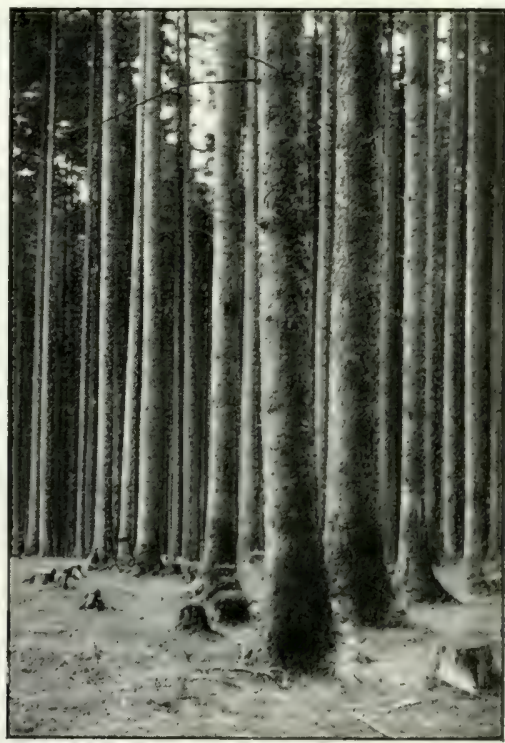

57. BAYAILAN SERUCF FOREST. 

tions in this country are few, and much depends upon the surface conditions at, or immediately after, the sowing. Scots pine is successfully sown on sandy soil in Germany, spruce in Bavaria, silver fir in the mountain districts of Central Europe, maritime pine in Gascony, etc. In Britain, however, sowing of conifers has rarely been a success when tried, but the cause of failure is not casy to explain. On thick grassy surfaces the seedlings of most small seeds have little chance in any case; but it is possible that slugs and birds are the two chief causes of failure, combined with the ease with which conifer seedlings are lilled by drought during the first summer, or thrown out by frost during the first winter. On peaty soils, however, sowing would probably prove a success in many cases, but here again trouble from frostlifting is general in Britain, whereas on the Continent a thick snow covering usually protects them in winter.

Several broad-leaved species, such as oak, chestnut, etc., can however be sown in situ with little trouble, provided protection against such animals as mice, pheasants, etc., is given them. A century or so ago sowing was the usual method practised with these species, but for several reasons, the chief probably being the great quantity of seed required per acre, the custom has been discontinued.

Natural regeneration very largely depends upon a number of factors which are rarely found in combination on a large scale, or over a large area. Many of these factors are connected with surface conditions, depending upon various forms of vegetation either resulting from soil, situation, or artificial interference with the timber crop. Others are closely connected with climate, and especially rainfall, which latter may enable seed to germinate, and the plants to survive under surface conditions which would otherwise prove fatal to them.

Amongst the common species, weech, ash, sycamore, 
birch, and alder can usually be relied upon to reproduce themselves satisfactorily in the absence of ground game, proviled the surface is comparatively clean and free from thick grass or bracken. Under certain surface conditions Scots pine also reproduces well, but is more difficult to regulate in economically worked woods than most species. Silver fir, if grown in thick clumps of an acre or more in extent, would probably regenerate as well in Britain as on the Continent, but spruce shows less capacity in this respect. Larch occasionally comes up well in small patches, but not on a scale large enough to prove of great value, while isolated or occasional instances are recorded of Douglas fir, Abirs nobilis, Truegu mertensiana, Thuia yiguntea, etc., self-seeding in various places.

The value of natural regeneration depends greatly upon the object with which the woods are managed, the character of the soil and situation, and the area of ground being dealt with. Under certain soil and climatic conditions a species might regenerate itself easily and freely, but fail to develop into a profitable crop owing to the particular kind of timber being little in demand, or the soil and situation being unfavourable. Sycamore and ash on dry, shallow soil or high-lying situations might be cited as instances of such cases. In very small woods, or those which require very intensive cultivation to make them pay, natural regeneration of species like birch or alder may be of little advantage, as the final crop is too small to yield a good return.

Natural regeneration is chiefly successful with ash on good, rich soils at low or moderate elevations, beech on chalky or sandy loams, sycamore on strong, clayey soils round the margins of woods, and birch on high-lying and poor soils. With proper management, and with ground game kept in check, neither ash nor beech give any trouble. The former is best worked on the selection 
system, the latter on the high forest group system, and modifications of these may be found in most parts of the British Isles. Possibly the only extensive regeneration of beech on cornmercial lines takes place in the Chiltern Hills, where it has been stated that annual nett profits of 20s. to $30 \mathrm{~s}$. per acre are obtained since the development of the High Wycombe chair industry. Ash regenerates itself freely in every copse and broad-leaved wood. Birch usually takes the place of Scots pine in many parts of Scotland and elsewhere, wherever the surface is covered with heather, but only occasionally are the conditions suitable for the successful regeneration of the last-named species.

3. Pover of resisting drought, frost, wind, insects, fungi, etc.

Injurious drought is seldom an annual feature of the British climate. It is often injurious, however, on dry or thin soils in the south and east of England, where rainfall is light. With drought, again, larch is often the chief sufferer, and after a month or more of dry, hot weather it shows signs of distress by yellow and withered needles, -and in extreme cases by needle-shedding, subsequently starting into growth after the rain comes. Spruce also suffers on dry soils to some extent, but neither of these species should be planted on thin soils in a dry climate, with the idea of getting large timber.

So far as the common species are concerned, winter frost rarely causes damage in Britain. Severe winters with temperatures below zero F. may occur, and occasion the death of badly ripened wool in oak, chestnut, and other species liable to grow late in autumn, and young plants generally are often damaged by hard frost in the absence of snow. Early and late frosts are often more destructive, but even early frosts are only occasionally injurious to a few species. The chief frost damage in the British Isles, however, is invariably caused by late frosts 
in May and June, and this liability to damage appears to be as great with indigenous as with introduced trees. Ash, beech, silver fir, oak, Spanish chestnut, walnut, Sitlia spruce, Douglas fir, etc., are all subject to this injury, while sycamore, elm, poplar, alder, willow, birch, etc., are seldom touched. Young trees, and those growing in valleys or hollows, are the chief sufferers, while those with tops twenty feet or more ahove the ground usually escape serious injury.

The effect of late frost damage, however, depends upon the soil and situation in which the trees are grown. On high-lying or sloping ground, and aspects facing away from the rising sum, frost inflicts less injury than on cold, damp soils, in hollows or valleys, and on eastern aspects. These facts are well known and repeatedly confirmed by experience, and practical men seldom plant, if they can avoid it, localities subject to late frost with tender species.

Probably the injurious effect of late frost upon trees like ash, beech, silver fir, and oak is an inherited weakness, due to the fact that they are seldom exposed to low temperatures under natural conditions when in the young stage. All natural regeneration, or nearly all, takes place under the shelter of the parent trees, and it is not until the trees attain a height of ten to twenty feet, or until the parent trees are blown down or removed, that they are fully exposed to frost attacks.

Resistance to persistent wind as a specific feature is chiefly conspicuous in sycamore, ash, beech, silver fir, Corsican pine, Sitka spruce, etc, and is chiefly deficient in larch, Douglas fir, Thui gigantea, etc. Absolute resistance to wind depends largely upon summer temperatures and vegetative vigour, as influenced by elevation and quality of soil, and also upon methods of cultivation, such as density of cropping, etc.

Liability to injury from insects and fungi is a very vari- 



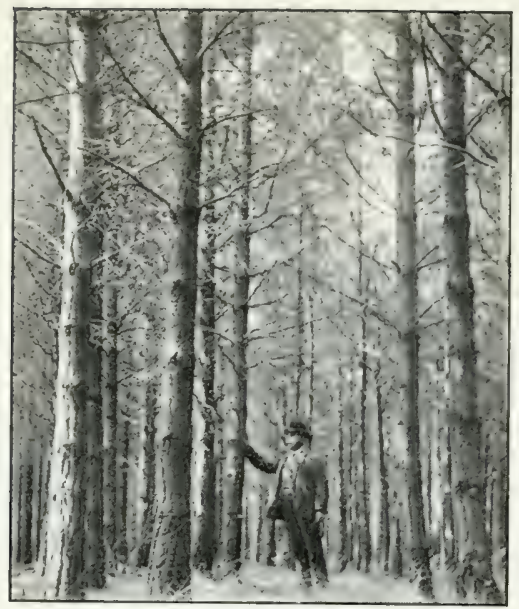

$5^{8}$ SCOTS PIXE THIRTY YeARS OLI. NORIIITHERLANI).

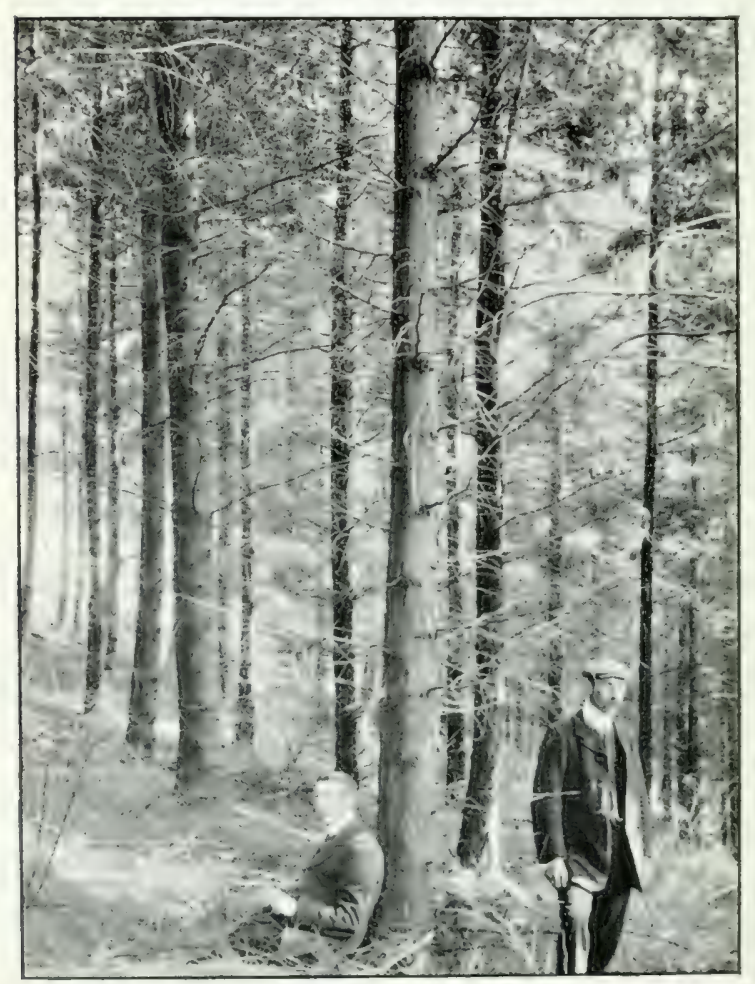

67. THUIA GIGAI:A, WATA, AT GAIRLETTER, ARGYLISHIRE. 
able feature with all species, and cannot be considered apart from other factors, especially soil and situation. While certain species, such as larch, may be almost lecimated by disease or insects in one locality, they may be perfectly free in another. Species, again, may escape these injuries for years or generations and then become victims on a large scale. The larch sawfly, beech-felted scale, silver fir and Weymouth pine aphides are familiar examples of new insect attacks; whilst amongst fungi the larch disease and heart-rot among larch, the pine blister on Wermouth pine, etc., are terribly on the increase in many districts. Other insect and fungoid pests, again, only appear at intervals, while some are only destructive on young trees or seedlings. The oak leaf roller moth, pine sawfly, pine weevil, etc., are instances of these respective types.

Of all forest trees probably larch is the most subject to both insect attacks and fungoid diseases of a serious nature, and especially so in districts or on soils which do not suit all its requirements. Next to larch, Scots pine suffers badly from the pine beetle at all stages of growth except where precautions are taken in removing breeding material, or fellings are uncommon. Apart from these two species it can scarcely be stated that any British forest tree is seriously troubled with either diseases or insects of great economic importance, except as individuals, or on unfavourable sites which check growth, and increase the relative importance of the parasites.

4. Ability to grow rapidy on comparatively poor soil.

In many respects the value of any forest tree largely depends upon this quality. On good soils practically all trees grow rapidly for a few years, but specific rate of growth varies with the soil and situation, and while some species show a growth directly proportionate to the richness of the soil, others are more influenced by local climate and situation during later stages. 
The majority of broad-leaved trees, such as oak, ash, sycamore, elm, chestnut, etc., are all lovers of good soil, and with the exception of the last nanned, require a fair amount of moisture to produce heavy timber. Beech is perhaps the only important tree which will reach a fair size on thin, dry soil, but even with this species fertility is not a negligible quality. With conifers, on the other hand, quality of soil is not such an all-important point. Scots pine, Douglas fir, and silver fir require a certain depth, but not necessarily great fertility, while spruce and larch will grow on the thinnest soil provided that sufficient moisture is available during the growing season. This capacity of the conifers for growing on poor soils has doubtless been exaggerated by many foresters, until it has almost become a proverb that they will succeed without soil at all. They will, at any rate, produce heavy crops of timber on land too poor to give a profitable crop of oak, ash, or even beech, and their value as timber species is increased accordingly.

Assuming that the poverty of soil increases with a decrease in the depth of porous and aerated material, whether loam, sand, clay, or gravel, it would follow that shallow rooters such as larch or spruce are of more importance in forest economy than deep-rooting species. While the former will grow on deep soil, the latter will fail to produce a profitable crop on shallow ground. Given certain physical and climatic conditions, therefore, spruce and larch may be considered capable of growing on soil absolutely worthless for any purpose of an agricultural nature. These different species of trees, therefore, must take first place in British forest economy in mountain districts.

Next in importance comes species demanding a certain depth, but content with comparatively poor and dry 
soils like gravels and sands. The pines, silver fir, Douglas fir, beech, and Spanish chestnut, may all be grown successfully on soils too poor to produce good oak and ash. In Great Britain these species must be planted at a moderate elevation to yield an adequate quantity of timber, but on the Continent they can be grown between 1000 and 3000 feet, Scots pine and chestnut north of the 52nd degree of latitude possibly excepted. Soils suited to their requirements in Britain are, as a result of this limitation, more or less mixed up with agrieultural lands, and large areas cannot always be obtained for their cultivation.

5. High quality or specific value of timber.

Some of the most valued qualities of many timbers, and those generally recognised, are straightness of growth and freedom from knots. These qualities are largely dependent upon proper methods of cultivation, and do not necessarily constitute specific characters. The latter, more or less, are usually peculiar to the species and inherited rather than acquired. The qualities most highly prized by manufacturers and users of European timber are strength, durability, and elasticity. Grain or figure, colour, power of taking a polish, and other ornamental qualities are not now valued so highly in British timbers, owing to the number of foreign fancy woods imported from many quarters of the globe, but a timber which is brittle, falls easily into decay when exposed to weather, or lacks sufficient strength and durability to be employed in permanent work, is seldom thought highly of. To the forester or landowner, therefore, the value of high quality timbers nust be largely determined by rate of growth. However valuable a species may be per cubic foot, the number of such feet produced per acre per annum will determine whether it can be termed a profitable species or not. Oak, locust tree, yew, etc., are all valuable timbers for certain purposes, but their rate of grow th per acre is too slow 
to render them profitable under ordinary conditions. Other species, again, grow rapidly as individuals, but require too much space, or are too irregular in their development, to produce a heavy crop of large timber. Sycamore, walnut, and in some cises ash, are instances of trees which bring a very high price in the shape of large trees, but can seldom be grown profitably as crops, on account of their uncertain development throughout the rotation. These species also require a great deal of space to grow to the girth at which they bring high prices, and this necessarily reduces the number of trees per acre which can be calculated to arrive at maturity. Grown sparingly in mixtures with more profitable species, or in groups of small size, it is often possible to use them with advantage, but as pure crops they have never yet attained any great reputation as high rent yielders on British soils.

Quality, as seen in the price per cubic foot alone, is therefore no reliable indication of profit to the producer, and unless accompanied by a fairly high yield in volume per acre, the species possessing it may be easily grown at a loss. Species which contain the two essentials are not numerous. Larch, on the right classes of soil, is the best-known example, but on unsuitable soils cannot be greatly relied upon. Weymouth pine, Douglas pine, ash, Spanish chestnut, etc., are probably the most reliable species for producing timber of good quality at a rapid rate, but all of them are somewhat limited in their ability to grow on various soils and situations.

Fineness of grain is also a valuable quality for certain purposes, and may be acquired by cultivation, or constitute a specific character. Spruce and Scots pine grown in close order are examples of the former; sycamore, beech, and birch of the latter. In crops which have to be artificially raiserl at considerable expense it is also doubtful if quality 


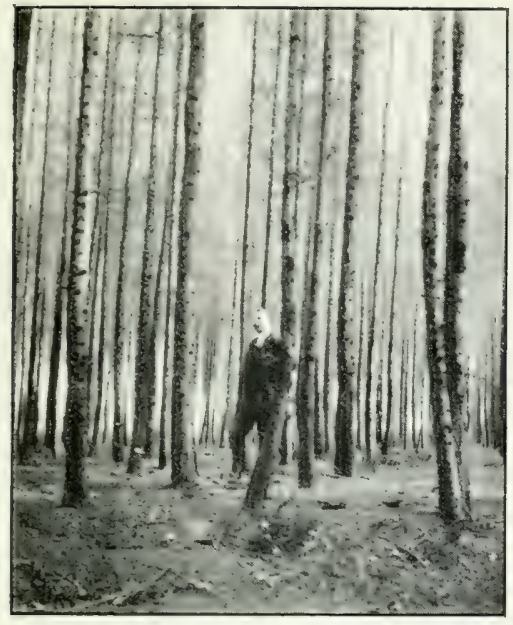

59. PURE LARCH WOOI) TWENTY YEARS OLI).

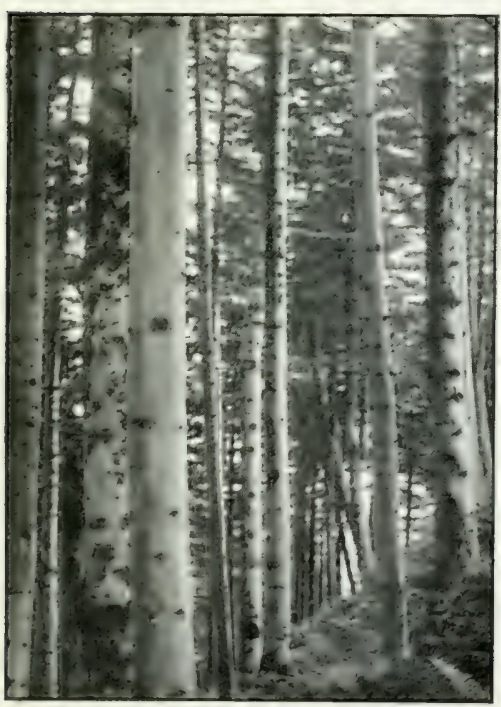

6I. SIIJER FIR WOOI ON MOUNTAIN IIMESTONE, SILEO

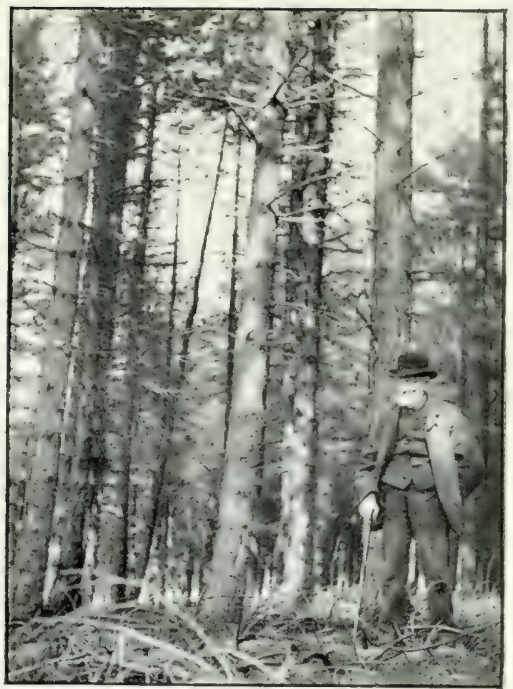

60. Corsican Pinf, chump, Sooft, Northumberi.ANI.

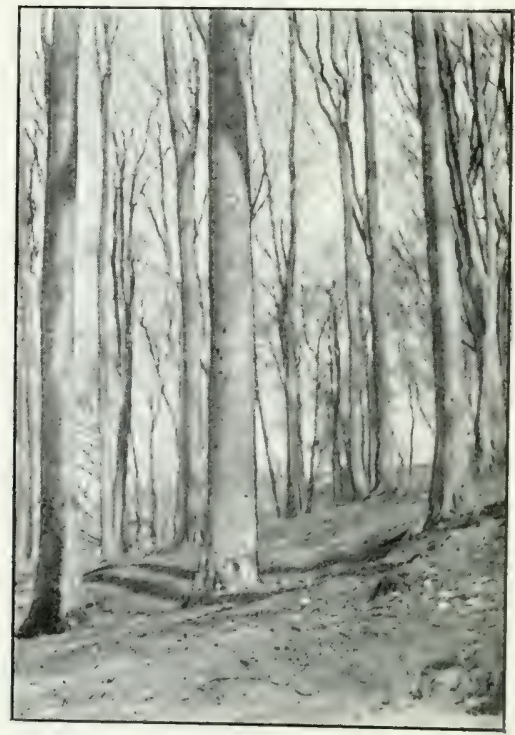

62. IBEECH HIGH FOREST. 

gained at the expense of very slow growth is always profitable. The fine-grained spruce and Scots pine imported from Scandinavia in to Great Britain, which is sold at about 1s. to $1 \mathrm{~s} .6 \mathrm{~d}$. per foot in the semi-manufactured state, takes from 100 to 200 years to reach timber size. To artificially grow timber profitably at the same rate as this a much higher price would have to be obtained, possibly $3 \mathrm{~s}$. to $5 \mathrm{~s}$. per foot, taking into consideration the large proportion of faulty timber which is associated with such long rotations. This fact will probably tell its own tale, in the course of a few years, by higher prices for all timber capable of cutting into big scantling.

Grouping the more important species capable of growing in British woods according to the qualities or disabilities named above, it is found that larch, Douglas fir, Weymouth pine, Spanish chestnut, and ash are probably the only species which combine high quality or valuable timber with rapid growth. Their cultivation is limited, however, by their demands upon the soil and situation, and except in sheltered spots, or on land generally fit for agriculture, they cannot be extensively grown. Their chief place will be found either in woods existing on the better classes of soil, or in favoured spots on large areas of the hill or mountain type. Valuable as they may be per acre or tree, therefore, they are not likely to form the backbone in any large scheme of afforestation on poor land.

Larch might possibly be considered an exception to this statement, but it must be remembered that this species only attains its full development in a comparatively small number of plantations amongst the large number in which it is planted. Apart from its value as a nurse, and in early thinnings, therefore, this tree cannot be regarded as a perfectly reliable species. Grown in mixture, however, larch should still constitute the bulk of the 
trees planted in Great Britain, as it can usually be relied upon for forty or fifty years, and at this age no species capable of cheap planting can be found to take its place in ordinary woodlands.

Weymouth pine again, although a fast grower and producer of valuable timber, is very subject to the attacks of the blister disease, Peridemium strobi, and in the opinion of Professor Somerville may have to be given up altogether as a timber tree in this country.

The value of Douglas fir in British forestry has now been clearly established in all parts of the kingdom, prorided the situation is not exposed, and the soil is not wet or does not contain more than 2 or 3 per cent. of carbonate of lime. The poorest and driest gravels will grow this tree as successfully as Scots pine, but the best development of the species takes place on deep loamy gravels, in valleys or eastern aspects, with sufficient moisture to supply the requirements of vigorous growth. In the shape of Oregon pine the timber of this tree has long been imported into Britain, and is extensively used for beams, pillars, and other scantling of large size. It stands weather remarkably well, and for this reason has been suggested as a substitute for larch in fencing. It has been tried in Scotland for sleepers, and compares favourably with other home-grown species for that or most other purposes.

In a valuable monograph on this tree in the Transactions of the Royal Scottish Arboricultural Society for January 1908, Mr. J. D. Crozier points out the value of Douglas fir for underplanting larch, or for filling up old or gappy woods. Examples of underplanting on the Durris estate show that the Douglas produces an equally good effect upon the larch as beech, but possibly the cool, damp climate may have something to do with this. On dry soils or localities it is doubtful if Douglas should 
be used too much in association with larch, except when the latter is regarded as a nurse tree.

The yield capacity of Douglas is probably greater than any good timber tree that can be cultivated in the British Isles. The well-known Taymount plantation, now fifty years of age, was measured by Prof. Somerville in 190:), and found to contain 7977 feet, equal to 155 cubic feet per acre per annum, and measurements by other authorities give somewhat similar results. Whether this plantation is more favourably situated than the average is a matter of opinion, but there is little doubt that a production of 100 cubic feet per acre per annum can be relied upon wherever the conditions are up to the average for conifer growth, and away from wet or limestone soils, or windy situations. The best nurse for Douglas is either Japanese larch, spruce, or silver fir, according to the density with which it is planted. At distances of 12 feet or so, a quick wrowing tree, such as the Japanese larch, must be used to prevent the development of side branches. With closer planting, say 6 or 8 feet, spruce or common larch scrve the purpose as well as any, and are much cheaper than the Japanese larch.

Spanish chestnut is a valuable broad-leaved species for sandy soils in the south and east of England, or wherever dry, deep soils prevail south of Scotland, the latter country generally being too wet and cold for its development, although occasionally good specimens may be met with. 'The yield and value of chestnut as a crop depends largely upon methods of cultivation, but the best results are probably obtained from coppice woods worked on rotations of ten to fifteen years. In Sussex and Hants shorter rotations of seren or eight years paid well at one time for producing rods and hoops, but the demand for these has now dropped considerably, and the tendency is to work on longer rotations. As a timber tree, in the 
ordinary sense of the word, the chestnut has the reputation of becoming shaky after the fortieth or fiftieth year. This fault, however, is not nearly so common in Ireland, where splendid chestnut timber three to four feet in diameter, and perfectly sound, may be met with. When of these dimensions it makes a first-class furniture wood, the almost complete alsence of sapwood, and the fine grain and figure, giving it as good an appearance as oak, or even better, while it is less liable to warp or crack, and easier to work.

The best method of growing chestnut for timber is in mixture with larch on dry soils, allowing the latter to grow as long as they keep sound, and keeping the chestnut as a coppice after the first thirty or forty years. Its liability to late frost damage renders it unsuitable for frosty hollows, or any sites particularly liable to this injury. In the south of England and in warm districts generally the chestnut grows to an enormous size if allowed to stand, but its timber value in these cases is practically $m i l$, for the reasons already given.

Ash is so well known that it needs little description. Its requirements in the way of soil are greater than those of climate, and on comparatively high-lying land large trees may be found wherever the soil is deep and fresh. On most large areas it must be confined to the better and fresher soils found in ravines or gulleys, or to alluvial tracts generally. The great value of ash, apart from its high price, lies in its self-seeding powers, which enable it to spread over large tracts by self-sown seed when once established, very much as in the case of sycamore. This character renders it necessary for the forester to treat it as a weed on land not adapted for its development, otherwise a comparatively worthless crop results, for few timbers vary so much in quality and value as this.

The second group of species given above are probably 



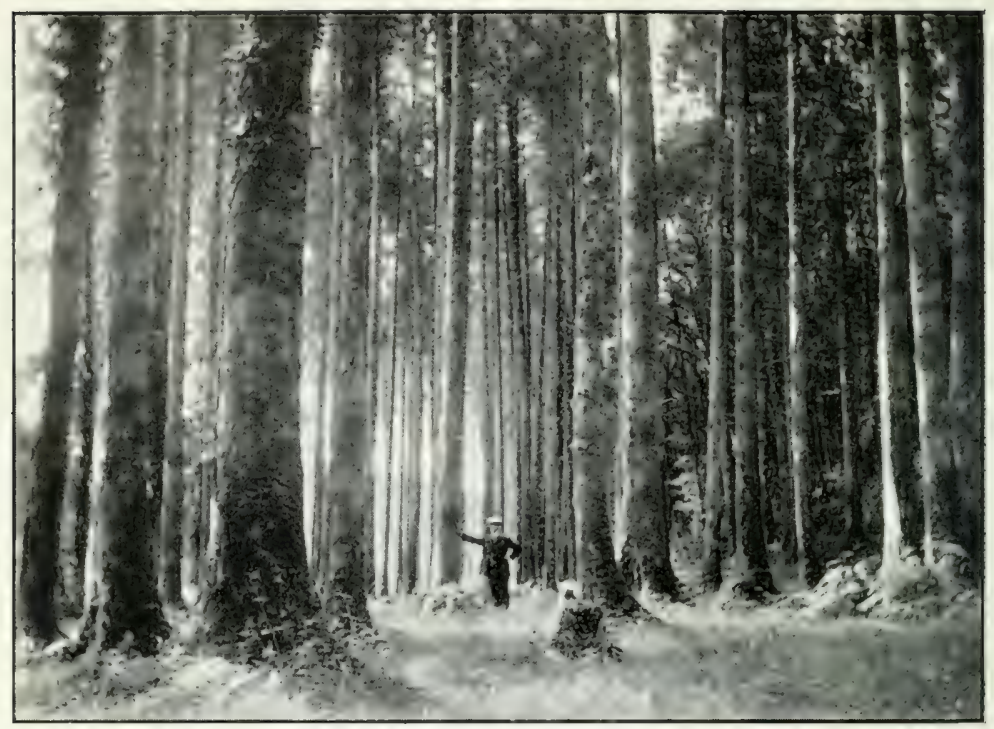

63. Spruce chump' Co. Cork.

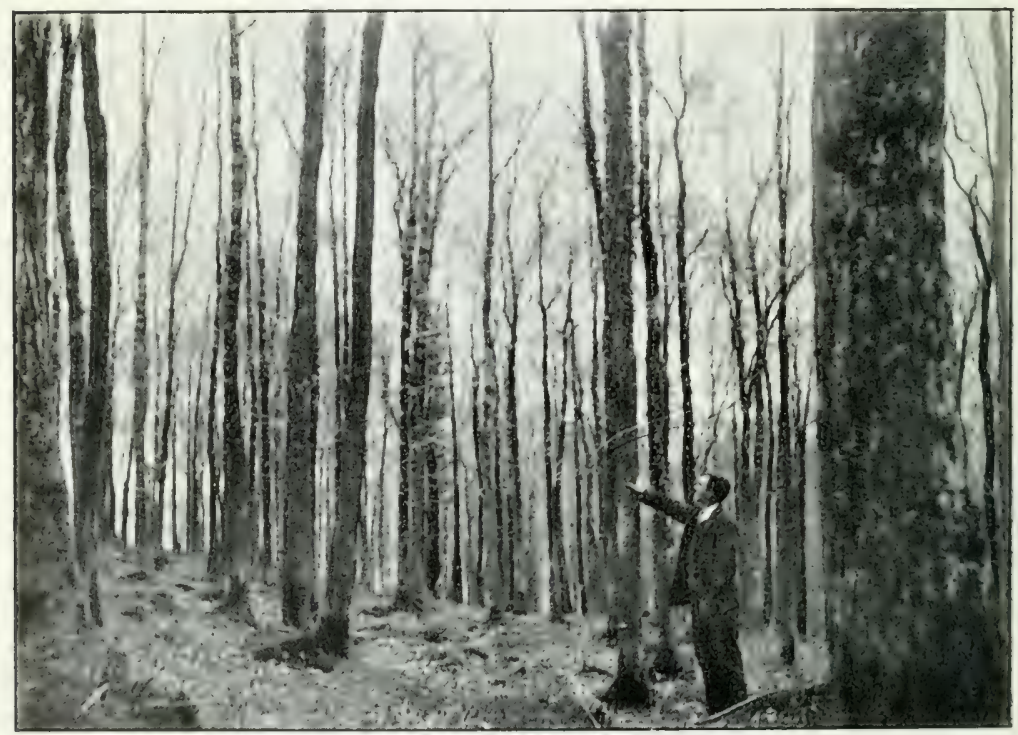

64. OAK FROM COPPICE SHOCTS. IRELAND. 
the most important, as their power of growing on moderate land and at high elevations enables them to be used on a large scale. The lower value of their timber is usually compensated for by their high yield per acre, and their comparative freedom from disease and insect attacks in this country. The bad reputation for profit which most species of this group have gained in the past must be largely attributed to the methods of growing them, especially in regard to sharle-bearers, which require much closer crowding than these trees usually have been given in mixed plantations. Their value greatly depends upon their being grown in bulk, so that economies may be effected in their growing, handling, and conversion. This is the principal reason why so much better results follow their cultivation on the Continent, where they form practically nine-tenths of the timber grown.

The relative values of the different species depend greatly upon soil and situation, but apart from these: rapidity of growth, accompanied by absence of coarse branches, will probably determine the nett profit likely to follow their use. Corsican and Scots pines amongst pines, Sitka and Norway spruces amongst spruces, are probably the best species of their respective genera. With the first named, special care must be taken in transplanting, otherwise no difficulty of a greater nature than is experienced with other trees need occur. Amongst silver firs it is doubtful if any can be found which are better all round than the common European tree, provided it is protected against late frosts by proper cultural methods. Of the American species, Abies grandis would appear to be the most promising, but it is not known whether it will stand wind as well as Alives pectinale, although it is less liable to injury from late frosts.

Amongst broad-leaved trees beech is probably the only one adapted for growing on a large scale on com- 
paratively poor soils, and its value even then is connected more with its effect upon the soil and fellow-species, and its power of reproduction, than upon the intrinsic value of its timber. The latter is greatly valued in firewoodconsuning countries, in which the smallest twig can be utilised, but in many parts of Britain most of this class of wood can only be given away. Clean growth has more than anything else to do with the value of beech, and it has usually shared the same fate as spruce, silier fir, and other shade-bearing species in being grown in an evenaged mixture with slow-growing, light-demanding trees, in which it either makes too much room for itself by cutting out its weaker neighbours, or is planted so thinly as to prevent its ever attaining any value as a crop. Except in wet soils, or at elevations above 1000 feet, beech should be introduced on a larger or smaller scale into all mixtures in British woods. In windy districts or exposed sites it is invaluable in excluding wind from the interior of woods, and in rendering them wind-firm in stormy weather.

The timber of few trees probably depends more upon the nature of the soil upon which it is grown than that of the Scots pine. On rich loamy soil its timber is soft and broad-ringed, with little resin, and seldom of much use for important purposes in which strength and durability are concerned. Grown on fairly deep but sharp, gritty gravels, loams, and sands, and in situations which produce a moderate growth, timber from mature trees is regarded as second to none for most structural purposes. The most frequent mistake made in connection with Scots pine in Britain is that of growing it in mixtures instead of as pure or permanent crops, and in planting it on too good soils on the one hand, or too shallow soils on the other. At high altitudes, again, Scots pine is invariably a failure as a timber tree, partly because it 
suffers much from snow during the winter, and partly because the soil or local climate is too wet and cold for its success. In mixtures of faster growing trees, such as larch, Douglas fir, or any of the more rapid growing conifers, Scots pine seldom or never reaches maturity, and is of little use when taken out as thinnings. To some extent creosoting has increased its value when young, but it is still far from being a profitable tree, except when grown as a pure crop, and under conditions which enable it to reach maturity.

Similar remarks might be made about Corsican pine, except that it grows at a faster rate, succeeds better in windy districts, and produces a cleaner bole with open order than Scots pine. Its timber is probably not so fine-grained as Scots pine under any circumstances, but for limestone soils it is certainly the best pine that can be used, provided that the necessary precautions are taken in transplanting.

It is probable that no more promising timber tree has ever been introduced into the British Isles than Sitka spruce. Until the last twenty years or so this fact had scarcely been recognised to the full, but there seems little reason to doubt that this is one of the very few introductions which have exceeded expectations.

Coming from a remote corner of the American continent, and probably not valued above other species in its own home to any great extent, it was not until it had been planted under conditions, which to most trees would have been fatal, that the qualities of Sitka spruce became of general knowledge. On peaty or wet soils, at high altitudes, and along the western seaboard, no tree appears to succeed so well in Scotland, Ireland, and the north of England, and only in the driest parts of the British Isles does it show any sign of failure. On the west coast of Jutlund, Schleswig-IIolstein, etc., the same superiority of 
this over other trees is noticed. While the quality of the timber is probably no better than, if as good as that of clean, slow-grown Norway spruce, it is certainly as good as any other species of the Picea genus, and has the additional merit of growing faster than any under ordinary circumstances. But its great value consists, as already indicated, in its ability to grow on the wet, sour soils of hillsides, bogs, and wind-swept aspects near the coast, and this is being more and more recognised yearly. In various parts of the British Isles it has attained a height of well over 100 feet, and girths of 15 to 20 feet at breast height. The latter are chiefly due to wide planting, and it is evident that close order must be maintained to grow commercial timber. Fortunately the seed of this tree is cheap and plentiful, and although delicate as a one-year seedling, and very sensitive to drought and late frost, no serious difficulties arise in either its raising or transplanting.

Although a great deal has frequently been said and written in favour of Thuia gigantea, it is difficult for the average forester to recognise in this species a valuable timber tree. It grows well on damp or peaty soils in humid districts, but stands persistent wind badly, and gives little or no indication of growing to a great size. The most favourable specimens as timber trees are probably those at Gairletter, on the Benmore estate, Argyllshire, where clean trees, 70 feet or more in height, and 12 to 18 inches in diameter at breast height, may be seen. At Powerscourt, where this tree has also been planted extensively, Mr. Laird, the forester, states that many trees are affected with heart-rot at a comparatively early age.

As valuable trees in localities near the coast-line of Ireland, Wales, the south of England, west of Scotland, or wherever the thermometer in the screen can be relied upon to keep above the zero of Fahrenheit, Pinus insignis and Cupressus macrocarpa may be mentioned. 


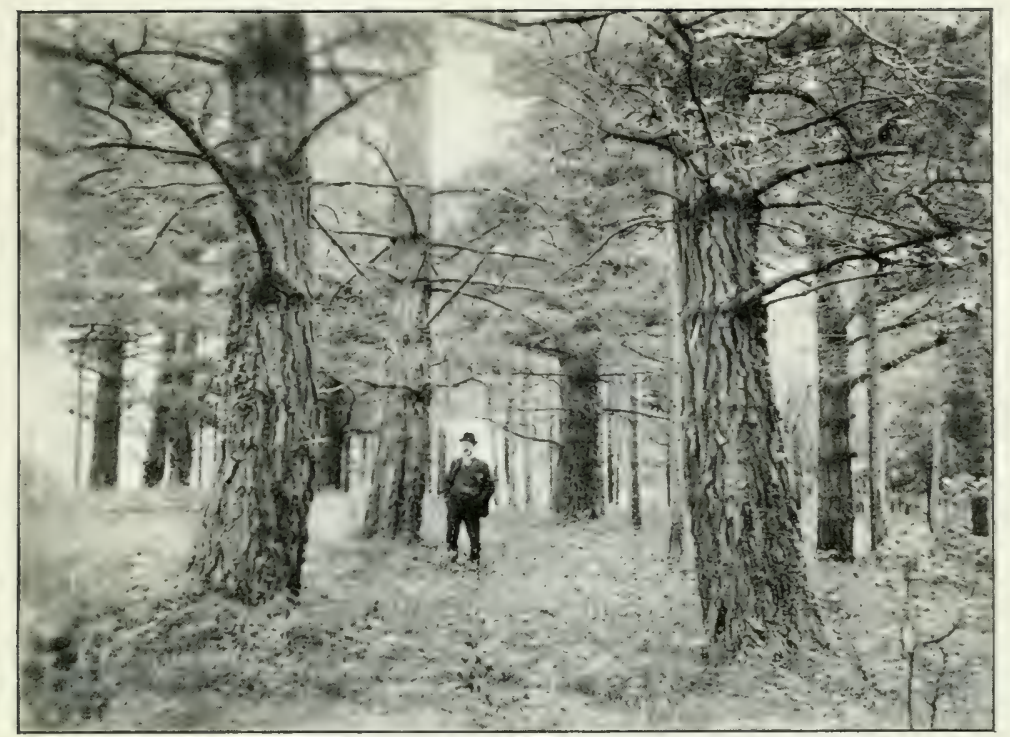

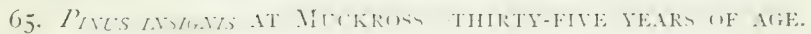

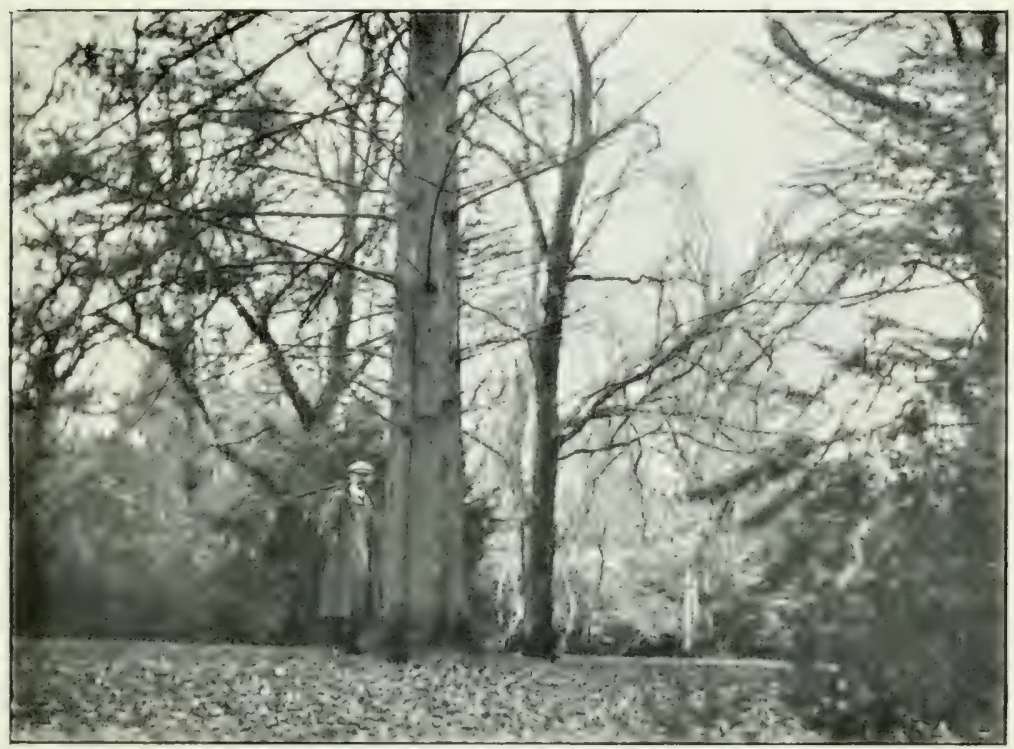

66. CUPRESSUS MACROCARPA AS A TIMBER TREE. 

The former can probably produce a greater bulk of timber in a given time than any tree capable of growing in the British Isles. At Muckross, near Killarney, specimens grown amongst larch contain 80 cubic feet of timber at the age of thirty-five years, and there appears to be nothing to prevent a yield of 200 cubic feet per acre per annum being given by this species when planted as a pure or permanent crop. The timber is coarse, soft, and brittle, but is quite well adapted for box-wood, and many other purposes of a temporary nature for which cheap timber is now used.

Cupressus macrocarpa is also a wonderfully rapid grower, and has the alvantage of producing very tinesrained and apparently durable timber. Grown in close order it produces straight and clean boles, and on dry soils within the influence of sea wind this species should have a future before it.

Unfortunately both these species are probably the most difficult of any to transplant under ordinary conditions, and it is only by constant transplanting, and the choice of mild, darnp weather for the work, that any degree of success can be expected unless they are raised in pots. The use of one-year seedlings, one-year transplanted trees, appears to give the best results.

For wet, swampy situations at low levels black Italian poplar, grey poplar, alder, and the two tree willows may also be included in this class. Their ability to grow on partially drained land, otherwise useless for most purposes, and their rapid rate of growth and adaptability for many classes of work for which cheap timber will always be used, entitle these species to special attention on the part of planters. Wood for packing boxes, indoor fittings, etc., can always be obtained from them, and in any large scheme of afforestation they must take an important although not perhaps a leading part, in securing good returns. 
If there are any other commercial species than those named above they will be found mentioned in the numerous books on forestry, beginning with Evelyn's Sylva, and ending with the last monograph on some recent introduction from a remote part of the world. In this connection, special acknowledgment must be made of that monumental work The Trees of Great Britain and Ireland, by Messrs. Elwes and Henry. As a book of reference to all who have to do with the sowing and planting of hardy trees, this work must remain a text-book for centuries, and although it greatly exceeds the requirements of the practical forester, the accuracy with which it has been compiled gives it a value which very few works can possess.

The list supplied above comprises abont nine broadleaved and ten coniferous species, one or more of which are capable of accommodating themselves to every possible soil and situation fit for timber-growing in Britain. Briefly summarised they are:-

On good soils and situations.-Ash, Spanish chestnut, Douglas fir, and possibly Weymouth pine and oak.

On medium soils with moderate exposures.-Beech, Scots pine, Corsican pine, Norway spruce, Sitka spruce, and silver fir. As nurses or main-crop trees generally on these soils, lirch may be regarded as suitable for universal use, but should rarely if ever be relied upon as a pure crop.

On high-lying and thin soils near the limit of tree growth.-Sitla spruce, Norway spruce, larch, and birch.

On swampy and lon-lying lend.-Black Italian poplar, grey poplar, Huntingdon willow, crack willow, and alder.

In mild, humid localities near the sea.-Pinus insignis, Cupressus macrocarpa, and possibly Thuia gigantea.

If first-class pine, spruce, silver fir, and beech timber could be produced in Great Britain, with larch in the form of poles, pit wood, and fencing timber, there is no reason why the present demand for building and constructive 
woods in country districts could not be met, and a surplus left over for use in industrial centres. With an improvement in quality of British-grown timber, the development of local wood-consuming industries would proceed rapidly, provided the requisite protection and encouragement were given them at the outset. Under present conditions, however, with all rural industries dying out or dropping into a decadent condition, it is difficult to see how the high technical skill existing in such countries as Scandinavia, Canada, or the United States, and applied to enormous supplies of naturally grown timber, can be successfully competed with in working up the timber of artificially grown woods in this country. In the shape of boards and scantlings of large size, the British market can take all that could possibly be produced at home, and a great deal more, but to convert British timber-growing into a really profitable concern the conversion of small timber must be made possible, so that from the twentieth year onwards the thimnings of plantitions may be disposed of at a price which leaves something over after the expenses of felling and marketing are paid. Turnery goods, chemicals, tamning material, wood pulp, and various other commodities capable of manufacture from small wood must be turned out of our forests if they are to be made the most of, and under present conditions this means some form of protertion to begin with, however independent they may be of aid later on. It may be that a plentiful supply of raw material will be sufficient to bring about developments of the kind required, but with the fate of so many British industries in the public eye one may be excused for doubting if new ones can be created without a certain amount of difficulty, perseverance, and patience on the part of the promoters, and sympathy and assistance from the State must be forthcoming if much is to be accomplished in this way. 


\section{CHAP'TER VIII}

\section{SOME FINANCIAL ASPECTS OF BRITISH FORESTRY}

THE question as to whether British forestry is a paying concern or not has frequently been discussed with greater or less warmth by interested parties. Considering that the majority of British woods are small, straggling, and irregular in ontline, require expensive forms of fencing, and are, in a general way, more subject to mismanagement than any in Europe, it is difficult to imagine how profit could form a prominent feature in the results obtained from them. On a few large estates, where woods are maintained with the idea of growing timber rather than that of producing game cover, laudscape effect, and many other features not connected with money-making, it has long been recognised that they can give as good an account of themselves as grazing or inferior forms of agriculture, and that a gross rental of from $10 \mathrm{~s}$. to $30 \mathrm{~s}$. per acre can be obtained without difficulty. As a rule, however, actual returns of the latter magnitude are only obtained from favourably situated individual woods and not from large blocks, and so far as the bulk of English woodlands are concerned it may be frankly stated that profit, calculated on strictly financial methorls, is neither obtained nor expected, and that estate woods generally are usually worked at a loss if the capital expenditure on them is taken into account.

One point has been established fairly clearly in both British and continental experience, however, and that is the fact that small areas of woodland are not profitable 
as a rule, and that the poorer the quality of the land, and the lower the value of the crop per acre, the greater the area must be to show a profit. This is chiefly due to the various economies which can be effected with large areas as compared with small. The fencing of large blocks can either be dispensed with altogether, or can be carried out at the lowest possible rate per acre. Supervision is easier, labour better organised and more efficient, and the cost of planting, thinning, felling, and other operations carried out at the lowest possible cost. In another direction, timber grown in big lots commands a better market, and attracts the establishment of timber-using industries to the vicinity of the forest, tending to an enhanced price and a continued demand. With certain species, again, large blocks become self-regenerative in time, and with skilful management they may be kept under a succession of crops with little or no expense to the proprietor.

On the other hand, large forest areas are more subject to insect pests, and possibly more exposed to wind and fire risks than small isolated patches; for strange as it may appear to the inexperienced, the nore a wood is constantly exposed to wind the better can it withstand its force. This immunity, however, is only gained at the expense of height growth, and cleanness of timber, and financially may be of no great advantage.

In Great Britain the fact is obvious that the better the land, and the more favourable the situation for agricultural purposes, the more difficult it becomes to procure large areas for any definite purpose, and especially to secure them at a low price. Apart from existing woods, the majority of which are individually small, the woodlands of the future must be formed in blocks of such a size as will enable them to be worked profitably on the lines already referred to. The minimum size for blocks varies with the soil, situation, markets for 
timber, and ownership of the land. On good soils and situations, and in the vicinity of good markets, woods of 50 to 100 acres can be profitably worked by the individual estate-owner, who can combine the supervision of several woods of this size with the management of the estate generally. For the purpose of State aftorestation such woods are too small, unless a number of them lie within a short distance of each other, but even then the expenses of fencing, and loss due to margins are greatly increased. 'Taking all things into consideration, experience indicates that less than 300 acres of comparatively good land can seldom be protitably worked as an independent block. The efficient management of smaller woods is very difficult, as properly trained men usually require higher salaries than such blocks can afford if a profit is to be made. Small areas, again, cannot provide annuil cuttings of sufficient size to place adequate quantities of timber on the market at one time, or if periodic instead of annual fellings are made, both the selling of the timber and the work of replanting become more expensive, and not so easily organised on economic lines.

On low-class agricultural land, blocks of 500 acres appear to be the most suitable size for all-round purposes, or several adjacent smaller blocks of the same or rather larger size in the aggregate. Areas of this size licep a good practical forester and a skilled staft steadily going, and when in proper working order provide an annual fall of timber from clearings and thinnings sufficiont to attract a number of competing buyers, and create a steady demand.

As the ground becomes poorer, the area required for working protitably becomes greater, until on the worst class of soils and situations less than 1000 acres cannot be regarded as a satisfactory working area. Apart from actual size, an area capable of yielding sufficient timber 
to supply a saw-mill working steadily throughout the year may be defined as a suitable minimum. When of this nature, the timber can be turned to the best account, whether sold to a timber merchant to work up himself, or sawn up by the forest staff, and sold in a converted state. Carriage of timber in the round, as is inevitable when small quantities are sold at one time, invariably means reduced prices, and accounts for the difficulty of selling swall lots of timber in isolated places at anything like a satisfactory price. With an annual output of 30,(100 to 40,000 cubic feet per annum, a mill worked by steam or water power, and running two circular saws, can be kept going, and under these conditions, profit is more likely to follow the working of an area of moderate size than when the latter is either too small or too large.

Next to the actual size of the area, the productive capacity of the soil and the annual profit obtainable remain to be dealt with. The usual method of calculating the expenditure and returns on forest areas is to take the acre as the unit of surface, and by calculating the cost of planting on the one hand, and the volume and value of imber produced on the other, getting out the nett profit at the end of the rotation. The mere fact, however, that timber of a certain value has been produced on an acre, or on a few acres of a particular block, affords little or no evidence as to the yield and possibilities of the latter, unless the sample represents a fair arerage of the bulk. On certain types of land of a uniform nature it is not difficult to judge whether this is so or not. With irregular soils and constantly changing situations it is, however, practically impossible to judge how far the results obtained from a small section of a wood are typical of those obtainable from the whole. Another practical difficulty in estimating returns is found 
in the indefinite nature of the life of a timber block of any size. With small areas of a few acres only it is possible to plant a crop on land previously consisting of arable or pasture, cut it clear at the end of fifty or sixty years, and bring it to tillage or pasture again in the course of a year or so. 'The profit or loss on such a crop can be estimated, given the necessary data, to a shilling or two. Such a case is merely that of a crop grown for a long instead of a short period, and the land after the removal of one crop is available for another of some kind.

But large woodland blocks are seldom, if ever, treated in this way. In these the stock does not consist of a single crop, but of a series of crops of different species, ages, and stages of development, and the proprietor of a block of this kind is rarely in a position to realise it at any particular moment, or to devote the land to agriculture or pasturage without a long process of preparation. What may be termed the winding-up financial statement of a large wood or forest is rarely possible. Such a block represents not a crop, but a working or going concern made up of land, buildings, fences, roads, growing crop, and numerous other appurtenances, without which timber cannot be grown any better than farm crops. The protit or loss upon the component parts of such a wood can scarcely be calculated more easily than the profit or loss on the roof or walls of a factory apart from the machinery, or the value of a piece of pastureland calculated apart from the grass which it produces.

It would appear to be much the better way to regard forest areas as a whole exactly as they must be regarded in practice, than to select the data relating to small areas which cannot stand alone under existing circumstances and surroundings, but must bear much the same relation to the remainder of the woodland as the apple bears to the tree on which it grows. In such a varied and com- 
plicated area as a woodland block of 500 to 1000 acres in extent, measurements must, of course, be confined to small areas, and unless the correct figures are available for a long period of time, these measurements are the only methods by which the productive capacity of the soil, or what is technically known as the 'locality,' can be roughly ascertained. But the most elaborate yield tables cannot indicate the actual nett profits from a large area, which must either be done from figures extending over a long period of years, or by an estimate of all the probable cost and expenditure until the woodland is in full bearing. After the latter condition has been attained, an excess of annual income over expenditure may be regarded as interest on the capital sum which has been invested in creating the woodland, or producing a normal crop of timber on the ground.

In making such an estimate the items of expenditure are many, those of income few. Expenditure might be divided into initial and annual, but until a normal stock, consisting of a regular series of age classes, has been produced, it is simpler and probably more correct from a practical point of view to regard all expenditure as capital invested, similarly as money spent in developing a company, or enlarging a factory, is invested capital, the interest on which is represented by the annual profits.

These items of expenditure may be summarised as follows:-(1) Land purchaserl, or converted from tillage or pasture to forest; (2) preliminary expenditure on builflings, roads, fences, bridges, arterial drainage, ete; (3) cost of plants and planting a definite area annually for the period of the full rotation; (4) expenses of supervision, caretaking, tending, etc., throughout the full rotation, and which come under the head of general maintenance at a later period.

Under the first head an expenditure of from $£ 2$ to $£ 6$ 
nr more may be allowed for per acre, but the latter figure should not be exceeded on an arerage for plantable land in large blocks. Land of a lower value than £2, or $2 \mathrm{~s}$. per acre annual value for grazing, will seldom produce protitable timber crops, although small areas may be found which are absolutely worthless for grazing, but capable of growing valualle timber. Laud worth inore than an average of $£ 6$ per acre, or from $£ 3$ to $£ 10$, must be regarded as too valuable for extensive afforestation, although small patches of valuable land must occasionally be included in large purchases. Under average conditions, however, from $£ 2$ for the poorer, to $£ 6$ for the better classes of land constitute the limit below or above which land for economic planting purposes shonld not be extensively acquired.

Under the head of 'Preliminary Expenses' come all those numerous items of expenditure which are invariably involved in a newly purchased property, more especially if previously occupied by different owners, or utilised for a different purpose. The provision of houses for overseers, foremen, and labourers may or may not be necessary, according as they may already be present on the land or not, but provision for gates, bridges, feneing, main drainage, etc., invariably has to be made, and a capital outlay of from $10 \mathrm{~s}$. to $30 \mathrm{~s}$. per acre is usually necessary for these purposes. The actual sum usually increases, but the cost per acre decreases, with the size of the area, and 20 s. per acre may be more than is required on compact blocks of 1000 acres or more, but much will depend upon various circumstances which can scarcely be anticipated in more than a general way. Miny of these items may not be necessary at the outset, as for instance the formation of roads or the building of bridges, but they may be regarded as capital expenditure whenever they have to be incurred. 
The cost of plants and planting is the most serious outlay in the formation of a forest area. It not only means a heavy annual expenditure for a series of years, but the crops resulting from that expenditure are liable to be damaged or partially destroyed by climatic or parasitic agencies, which may render one or more years' expenditure of little benefit. With small woods the work of planting is often carried out in one season, or at the most in two or three years. With an area which is intended to yield a steady income after a period of years, however, it is evident that the work of planting should roughly be spread over the period which is required for the earliest planted area to mature, otherwise a break will occur at some future period, or crops must be cut before they are ripe. In the planting of an entirely new woodland the rate of stocking need not be quite so gradual or methodical, as allowance must be made for uncertainties and variations in the development of the trees, which prevent rotations being fixed far in arlvance. In estimates, however, the normal state of things must be allowed for, viz., the planting of an area which corresponds to the annual felling when the wood is in full bearing, and this is or should be that fraction of the total, or the sum of the fractions of each working circle, which corresponds to the years in the rotation or rotations.

Calculated per acre, the cost of planting on a large and systematic scale maty be estimated at $\mathfrak{E}+$ to $\mathfrak{E}(;$, according to character of ground, species, and ages of plants. Ground with thick surface growth, planted with rare and expensive species, and with four-year-old plants, will cost on an average at least $\mathfrak{f} s$ or $£ 10$ per acre. Cheap seedlings notched into short heather may not cost more than $\mathfrak{£ 3 . ~ B u t ~ u s u a l l y ~ t h e ~ e x p e n s e s ~ o f ~ p l a n t i n g ~ l i e ~ b e t w e e n ~}$ these extremes. Of the total cost of planting, plants alone usually cost two-thirds and labour one-third, but much 
depends upon circumstances. The adaptability of the species for trinsplanting also affects the cost to some extent, as the expense of filling up is greatly increased or decreased according to this feature, and many circumstances of an accidental nature render the expenses of planting an uncertainty.

General maintenance will include the labour required for cleaning, thinning, upkeep of fences, nursery, drains, payment of rates and taxes, and supervision and caretaking. These expenses will usually increase slightly throughout the rotation, until an annual expenditure of about 5s. per acre will be required, chiefly made up of renewal or repairs to fences, cleaning of young plantations, and supervision, exclusive of the higher administrative charges necessary in large schemes.

If, however, the cost of nursery work, planting, cleaning, and filling up during the first five years is covered, general maintenance should be practically balanced by grazing rents in the early stages, and returns from thinnings after the thirtieth year or so, and on an average area may be disregarded in estimating the accumulation of capital charges. On very poor, high-lying land returns from thimnings are a very doubtful source of income at any time, but the expenses of caretaking or tending are very low, and the nett loss under this head may not be very great.

Incone will, on the above supposition, therefore, be nil until the area is in full working order. It is then derived from the yield of final fellings, the volume and value of which will depend upon the quality of the soil and situation. In estimating yields from a large area it is, however, necessary to allow for various factors which will inevitably reduce the average yield as compared with that obtained from a single acre, or derived from the productive ground alone. Fences, roads, waste ground, buildings, etc., all tend to bring the actual timber-growing ground down to a smaller acreage than that comprised in the 
whole area. An equally important point is to allow a fair margin for contingencies, bad or diseased timber, and other accidents which diminish the market value of a crop. These accidents are more likely to increase with some species than others, and also increase with the length of the rotation. Larch and spruce, for instance, amongst conifers invariably contain a percentage of faulty or diseased stems, while oak and ash seldom give a large return in first-class timber.

Above all, it is necessary to remember that yield tables, or the results of sample plot measurements, indicate standing timber crops which are 25 to 50 per cent. greater than may be expected from average yield from the forest or wood in which they are grown, assuming that the soil is uniform throughout. In Forest Management ${ }^{1}$ Sir William Schlich quotes in Appendix III. German yield tables of Scots pine, beech, spruce, silver fir, and oak. The calculations are expressed in cubic feet and acres, but the former are evidently obtained by calliper measure, and consequently must be reduced by 22 per cent. to bring them to English measure. After this is done yields of from 6000 to 10,000 feet of timber per acre three-inches diameter and over on first-class localities are given. Equally high returns are shown in Tables V. and VI. A British forester in selling large blocks or woods at one operation would seldom, if ever, find average stocks of timber of this kind on the ground, even after allowing for gaps and other defects in the crop. Timber measured down to three inches in diameter must also include a great deal which must either be burned on the ground, given away, or sold at a nominal price for firewood. Larch is perhaps the only tree which carries little waste in the shape of small timber, but with other, and especially broad-leaved species, considerable allowance must be made for branches and small tops which, at the best, can only be sold at half-price.

1 Vol. iii., Schlich's Manual of Forestry. 
Taking the normal growth of fast-growing species on average soils and situations, and with rotations of forty to eighty years, it will be found that an annualaverage increase per acre of from 50 to 80 cubic feet of marketable timber is as much as can be expected, exclusive of thinnings. Douglas fir, black Italian poplar, etc., may occasionally give more than 100 feet. Larch and ash seldom give more than 50 to 60 feet. An average of 60 cubic feet is the most that can be relied upon from first-class soils, taking the fact into account that the localities are limited for the faster growing species, and that unproductive land must be allowed for.

The average value of the timber of species like ash, larch, Douglas fir, Spanish chestnut, etc., will vary with the locality in which grown, but from $6 \mathrm{~d}$. to $1 \mathrm{~s}$. per foot on the ground is seldom exceeded in Scotland or Ireland. Near manuficturing centres in England higher prices are reached, but in such districts land for growing timber in large blocks can seldom be found.

With spruce, pine, silver fir, etc., and in localities which do not adnit of more than an average growth, an annual increment of 40 to 60 feet per acre may be allowed for, and an average price of $6 \mathrm{~d}$. per foot. The farther the timber is grown from industrial centres the lower the price that may be expected for it, and it is a fact that very little spruce or beech realises more than $6 \mathrm{~d}$. per foot, while a great deal of it makes less.

On the poorest and most exposed soils, as those at s00 to 1200 feet above sea-level, the yields from spruce and one or two hardy species seldom exceed 30 to 50 feet on rotations of about fifty years. Longer rotations than these mean losses from wind and decay, and as big timber is out of the question, nothing is gained by attempts to get too much from one crop. The price of third and fourth rate spruce cannot be put at more than $4 d$. per 
foot, or 10 s. per ton-that is, rather more than is obtained for it at the present time-and until the Scandinavian and Canadian supplies of pit wood and pulp wood are exhausted, the prospects of high returns from this class of soil are not great.

To illustrate the above points, the costs and yields of three typical areas may be estimated.

No. I. may be regarded as a specimen of a block of land which might be obtained in a poor agricultural district, with land varying from $5 \mathrm{~s}$. to $10 \mathrm{~s}$. in annual value, but containing no mountain or unenclosed pasture. For timber-growing purposes the land in such districts may be considered as good, and little or no waste would be likely to exist. The only disadvantageous feature of afforestation in such districts would be the limit placed upon the size of the area by the more or less general occupation of the land, and 500 acres has been taken as the greatest acreage likely to be obtained in one compact block, and purchased at an average price of $£ 6$ per acre.

No. II. is representative of a hill district which possesses a comparatively high value for grazing purposes, and which is intersected by valleys of good land thickly occupied by holdings. In these districts little absolutely waste ground should exist, but the higher elevation and poorer soil would reduce the timber-yielding capacity of the area capable of being acquired for planting. A block of 750 acres is assumed to be the size of this tract, and the value of the land to average $\mathfrak{f} 4$ per acre.

No. III. is assumed to exist on typical mountain land, and above the line of occupied holdings. Elevation usually limits the size of areas of this class, but a minimum of 1000 acres must generally be reckoned upon if a profit is to be obtained. The average value of this land would probably seldom exceed $£ 2$ per acre, while the yield in quantity and quality would also be low. 
The costs of land purchase, preliminary expenses, and planting costs, with compound interest thereon at 3 per cent., are shown in Table vi., together with the yield expected annually when the area is fully stocked. The annual costs of maintenance are assumed to be covered by grazing and sporting rents, and the intermediate returns from thinnings.

If the figures generally are compared with returns actually obtained in continental State forests, given in Table viII., it will be seon that the yields in saleable timber, as distinct from firewood, in the estimates are slightly higher than those usually obtained, while the prices per cubic foot are also well up to the general averages. As, however, the estimates apply to what would be compact blocks, and not to a number of detached areas of various sorts and conditions, neither yields nor prices can be considered excessive.

The costs of planting are also higher than published figures would lead one to expect. This is partly accounted for by the expenses of cleaning on land previously under grass or heather, and partly by the well-known fact that this work can seldom be done so cheaply in Great Britain as on the Continent, if a really satisfactory crop is to be left on the ground. They are also intended to cover cost of nursery work, and the necessary attention to the plantations up to the fifth or sisth year.

The most uncertain feature of the estimates is that which assumes the covering of general maintenance charges by grazing and sporting rents and thinuings. Any deficiency in this respect, howerer, should be balanced by the saving or postponing of preliminary expenses, upon which interest has been charged from the first year, while a certain sum may be expected from inferior timber not calculated in the annual yield per acre. The actual maintenance charges would vary generally 
with the size of the area, especially as regards higher supervision or administrative charges. The cost of a forester competent to manage 500 acres of woods would probably be almost, if not quite as grent as that of a man required for 1000 acres. The value of thinnings on the smaller area with better soil would, on the other hand, be higher, both by reason of the greater yield per acre, and the better demand.

As regards the nett returns given in official statistics of continental forests, it is invariably the case that they do not take into account interest on the capital invested in them. Their ancient origin, of course, prevents any calculation of this kind being made, but it is practically certain that if the true figures could be ascertained, the nett yields of $10 \mathrm{~s}$. to $20 \mathrm{~s}$. per acre given in Table virI. would be considerably reduced. This is a point which has been usually ignored in quoting the high returns from forests abroad, but it must enter seriously into calculations of profits on newly formed areas. The rate of interest charged on all capital expenditure in the estimates is 3 per cent., as this interest can be obtained from investments in any Government stocks at present market prices, and with the very best security money cannot be obtained for less on loan. After deducting a sum from the annual yield which would represent 3 per cent. on the capital cost value, therefore, it is seen that the nett profits on the specimen areas given are practically 7s. in the case of No. I., and $6 \mathrm{~d}$. in the case of No. III., per acre per annum respectively. No. II. shows a nett loss of 10 s. 6 d. per acre, unless a value of 9d. per foot is placed upon the timber, or the calculated costs bear interest at the rate of $2 \frac{1}{2}$ per cent. only, in which cases no loss is incurred.

The above estimates may be taken for what they are worth, but if they are approximately near the mark they suggest that timber cannot be profitably grown at present 
British prices, a fact which has long been recognised ly those who have looked carefully into the question. At a rough estimate, from $6 \mathrm{~d}$. to $1 \mathrm{~s}$. per cubic foot is the cost price of coniferous timber grown under artificial conditions in the British Isles, and probably well-grown timber will easily command that price in the future, when natural supplies are worked out, and all forest land requires protection and skilled management.

When forests are once thoroughly established, natural regeneration may reduce the costs of production to a low figure, and the nett profits quoted above may be increased by this probability. But after all favourable factors are taken into account, it is evident that economic forestry at present prices is not a particularly attractive speculation. Regarded from a national point of view, howerer, mere monetary gains sink largely into the background, and as pointed out in Chapter III, the gain in increased employment must be looked upon as a national asset of the greatest importance.

Compound interest, however essential a feature as it may be in a financier's creed, cannot be regarded as a vital factor in every national scheme undertaken for the public good. If applied, for instance, to British agriculture during the last 300 years, it is doubtful if it could show a return of 3 per cent. on all investments on buildings and improvements during that period, and it is a well-known fact that much forestry work is undertaken abroad which will never show a penny of profit.

In conclusion two specific cases may be given of returns from woodlands in England which are probably authenticated suficiently to render them of value for quotation purposes. One case is that of the income and expenditure connected with the woods on the Bedford estates in Bedfordshire and Buckinghanshire, which were published 
by the Duke of Bedford in 1897. ${ }^{1}$ On a little more than 4000 acres of woodland the income and expenditure during a period of sixty years were as follows:-

$\begin{array}{lrrcc}\text { Period. } & \text { Acres. } & \text { Income. } & \text { Expenditure. } & \begin{array}{c}\text { Balance per } \\ \text { Acre per } \\ \text { Annum. }\end{array} \\ 1836-55 & 4300 & 229,165 & 63,935 & 38 \mathrm{~s} . \\ 1856-75 & 4300 & 138,307 & 73,722 & 15 \mathrm{~s} . \\ 1876-95 & 4000 & 96,695 & 60,229 & 9 \mathrm{~s} . \\ & & & \text { Average, } & \overline{20 \mathrm{~s} .8 \mathrm{~d} .}\end{array}$

The high returns during the first period were evidently due to heavy clearings or fellings, entailing increased expenditure during the second period. If the average balance is accepted as normal, the interest on capital expenditure must be deducted before the nett profits are obtained. This would certainly not be less than $£ 40$ per acre, taking the class of land on these estates into ascount, and would probably be nearer the figure given in Table vi., or $£ 60$ per acre. With the former figure a loss of $3 \mathrm{~s} .4 \mathrm{~d}$. per acre is shown on a 3 per cent. basis, with the latter a loss of $15 \mathrm{~s} .4 \mathrm{~d}$. But in the absence of exact figures regarding initial outlay, the stock of standing timber, and the extent of the annual fellings, much must be left to conjecture.

The second instance refers to a wood of about 200 acres in Cumberland, lying at an elevation of from 900 to 1500 feet. As the data relating to this plantation are given in great detail in the journal of the Board of Agriculture and Fisheries for July and August 1910, only the general conclusions arrived at by Messis. Robinson and Watt (the authors of the article in the journal) need be given here. These gentlemen found that a larch plantation of sixty-one years of age, growing on land

${ }^{1}$ A Great Agricultural Estate. 
worth not inore than $1 \mathrm{~s}$. per acre annual value, was able to give a nett return of $14 \mathrm{~s} .10 \mathrm{~d}$. per acre. This return was obtained, firstly, by the low costs of planting ( $£ 2,17 \mathrm{~s} .2 \mathrm{~d}$. per acre), the sales of larch bark between 1866 and 1894 at $£ 3,10$ s. per ton, and the high average price of $10 \mathrm{~d}$. per cubic foot obtained for larch thinnings in the wood. By increasing the cost of planting to $£ 5$, omitting the returns from bark, and reducing the value of spruce and Scots fir thinnings, the authors calculated that a nett return of $11 \mathrm{~s} .1 \mathrm{~d}$. would still be possible.

Applying the results thus obtained to Great Britain generally, it is safe to say that an average price of $10 \mathrm{~d}$. per cubic foot would not be obtained for larch under thirtyyears of age at any great distance from colliery districts, while a great deal of mountain land above 1000 feet would not produce commercial larch timber at all. As every forester knows only too well, the chances are about equal of larch being grown at a profit where it succeeds, and of its entailing a heavy loss where it fails. In any scheme of extensive afforestation it would be unsafe to reckon upon more than one-fourth of the total yield being obtained from larch, or any other species requiring certain conditions as regards soil and situation which are not universal over wide areas. If the experience of other countries is examined, together with the known facts relating to the growth of different species in Britain, it must be realised that the bulk of the returns from hillplanting on a large scale in the future will be obtained from hardy species which can be planted with some certainty of their reaching a marketable size, and producing a class of timber for which a steady demand will exist. On poor ground spruce at high elevations, pines at lower levels, and larch in suitable spots wherever it can be grown, appear most likely to give healthy crops and produce satisfactory financial results. On the better classes of 
soils a wider choice of species, a higher quality of timber, and a greater yield enable greater nett profits to be obtained, but at present prices very few soils and situations exist which can produce sufficient timber to yield a nett profit of more than 10 s. per acre per annum, after deducting 3 per cent. on the total capital outlay.

\section{TABLE IV}

Some British and Irish Yields per Acre

\begin{tabular}{|c|c|c|c|c|c|c|c|}
\hline \multirow[t]{2}{*}{ County. } & \multirow[t]{2}{*}{ Species. } & \multirow[t]{2}{*}{$\begin{array}{l}\text { Eleva- } \\
\text { tiou. }\end{array}$} & \multirow[t]{2}{*}{ Age. } & \multirow[t]{2}{*}{$\begin{array}{c}\text { Num- } \\
\text { ber. }\end{array}$} & \multirow[t]{2}{*}{$\begin{array}{c}\text { Aver- } \\
\text { age } \\
\text { Height. }\end{array}$} & $\begin{array}{c}\text { Total } \\
\text { Volune } \\
\text { per Acre. }\end{array}$ & $\mid \begin{array}{c}\text { Average } \\
\text { Yield } \\
\text { perAcre } \\
\text { per } \\
\text { Annum. }\end{array}$ \\
\hline & & & & & & $\begin{array}{l}\text { Exclusi } \\
\text { Thinni }\end{array}$ & $\begin{array}{l}\text { ve of } \\
\text { ings. }\end{array}$ \\
\hline $\begin{array}{l}\text { Northumberland, } \\
1 \\
2 \\
3 \\
\text { Waterford, . } \\
\text { "Cork, } \\
\text { Sussex, : } \\
\text { Scotland, : } \\
\text { (Quarterly Jour- } \\
\text { nalof Forestry, } \\
\text { vol. iii. p. 1, } \\
\text { 5Worcestershire, } \\
\text { "Wiltshire, . } \\
\text { Inverness-shire, . }\end{array}$ & $\begin{array}{c}\text { Scots pine, } \\
\text { Spruce, . } \\
\text { "' } \\
\text { Larch, . } \\
\text { Spruce, . } \\
\text { Beech, . } \\
\text { Larch, . } \\
\text { Scots pine, } \\
\text { Spruce, : } \\
\text { Douglas fir, } \\
\text { Oak, . } \\
\text { Silver fir,. } \\
\text { Larch, . }\end{array}$ & $\begin{array}{c}550 \\
1660 \\
600 \\
350 \\
300(?) \\
250 \\
\ldots \\
\ldots \\
800 \\
\ldots \\
\ldots \\
\ldots \\
500 \\
400\end{array}$ & \begin{tabular}{|r|}
100 \\
55 \\
46 \\
70 \\
30 \\
75 \\
$\ldots$ \\
63 \\
140 \\
80 \\
49 \\
$\ldots \ldots$ \\
120 \\
64
\end{tabular} & $\begin{array}{r}140 \\
480 \\
640 \\
175 \\
658 \\
250 \\
\ldots . \\
300 \\
110 \\
240 \\
188 \\
25 \\
27 \\
250\end{array}$ & $\begin{array}{r}70 \\
45 \\
50 \\
90 \\
60 \\
97 \\
\quad \ldots \\
80 \\
84 \\
98 \\
92 \\
110 \\
130 \\
85\end{array}$ & $\begin{array}{r}7,600 \\
3,400 \\
5,100 \\
6,100 \\
3,000 \\
14,000 \\
9,000 \\
4,500 \\
4,400 \\
6,960 \\
7,191 \\
7,000 \\
15,000 \\
4,500\end{array}$ & $\begin{array}{r}76 \\
60 \\
110 \\
85 \\
100 \\
180 \\
\ldots \\
71 \\
31 \\
87 \\
120 \\
120 \\
125 \\
70\end{array}$ \\
\hline
\end{tabular}

1 Calculated from measurements on $\frac{1}{8}$ of acre (Author

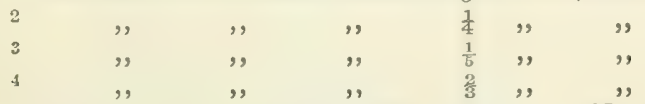

5 Group of oaks measured by Sir H. Beevor in Kyro Park.

${ }^{6}$ Calculated from measurements on $\frac{1}{s}$ of acre (Author). 
TABLE V

Extracts from Continental Yield Tables

(SchWAPPach)

\section{(Reduced to Quarter Girth Measure)}

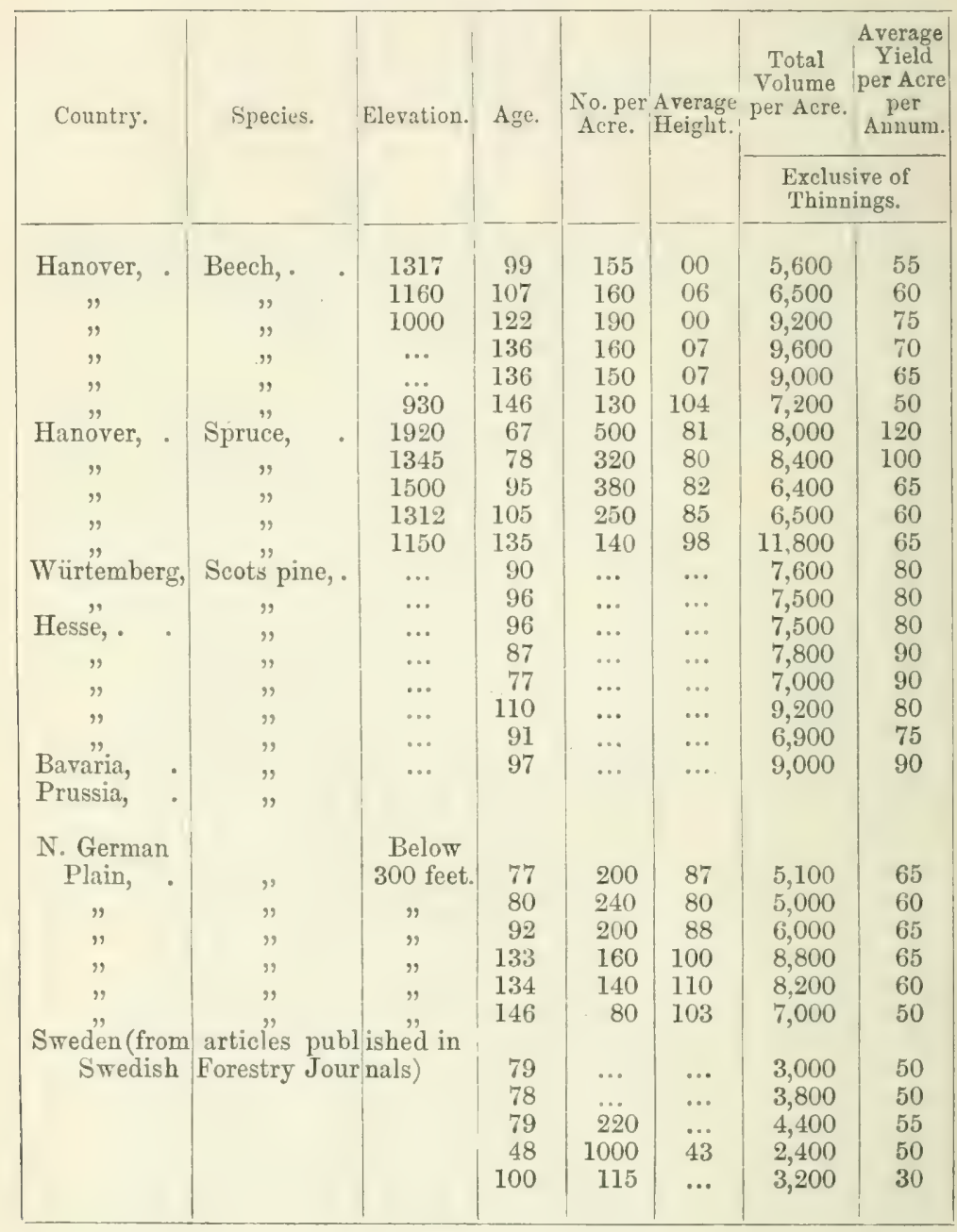




\section{TABLE VI}

\section{Showing the Capital Cost of establishing Forest}

\section{Blocks on a Working Basis}

\section{Specimen Block $I$}

Area of 500 acres of first-class planting land. Crops consisting of larch, Douglas fir, Weymouth pine, ash, Spanish chestnut, etc., worked on average rotations of 60 years.

Purchase of 500 acres at $£ 6$ per acre, . $£ 3000$

Amounting at end of 60 years at 3 per

cent, compound interest, .

Preliminary expenses at $£ 1$ per acre, . 500

Amounting at end of 60 years at 3 per

. cent. compound interest, . . 2,900

Planting, clearing, etc., 500 acres at $£ 8$

per acre, . . . . 4000

Amounting, if 8 acres are planted annually

for period of 60 years, to

Capital cost value,

$£ 17,600$ 


\section{Specimen Block III}

Ars of 1070 acres of third-class planting land. Crops consisting of larch and spruce, and worked on average rotations of 50 years.

Purchase of 1000 acres at $£ 2$ per acre, . $£ 2000$

Amounting at end of 50 years at 3 per cent.

compound interest, . $\quad$. $\quad$. $~ £ 8,700$

Preliminary expenses at $£ 1$ per acre, . 1000

Amounting at end of 50 years at 3 per cent., $\quad 4,300$

Planting, clearing, etc., at $£ 4$ per acre, . 4000

Amounting, if 20 acres are planted annually for period of 50 years, to

=21 $\frac{\frac{8,300}{£ 21,300}}{\text { per acre. }}$

Capital cost value,

$=£ 21$ per acre.

\section{TABLE VII}

Profit and Loss Account on Specimen Blocks, After allowing 3 per cent. Interest on Capital Cost Values

\section{Block I}

Annual yield from final fellings on 8 acres

at 3600 feet per acre $=28,800$ feet

at 9 d., . . . . $£ 1080$

Less 3 per cent. interest on $£ 30,200, \quad$. 906

Balance, $\quad \overline{£ 174}=6$ s. 11 d. p. ac.

\section{Block II}

Annual yield from final fellings on 10

acres at 3500 feet per acre $=35,000$

feet at $6 \mathrm{~d} ., \quad$. $\quad . \quad £ 875$

Less 3 per cent. interest on $£ 42,200, \quad$. 1266

Loss, $£ 391=10$ s. 5d. p. ac. 


\section{Block III}

Annual yield from final fellings on 20

acres at 2000 feet per acre $=40,000$

feet at 4 d., . . . $£ 666$

Less 3 per cent. interest on $£ 21,300, \quad$. $\quad 639$

Balance, $\quad \overline{£ 27}=6 \frac{1}{2} d$. per acre.

\section{TABLE VIII}

Showing the Yield of Timber and Firewood and Nett Yield in Money per Acre per Annum, also Average Price per Cubic Foot, as obtained in State Forests in Germany in 1905.

\begin{tabular}{|c|c|c|c|}
\hline State. & $\begin{array}{c}\text { Timber } \\
\text { and } \\
\text { Firewood. }\end{array}$ & Nett Yield. & $\begin{array}{c}\text { Average } \\
\text { Price per } \\
\text { Cubic Foot. }\end{array}$ \\
\cline { 1 - 3 } Prussia, . . & $\begin{array}{c}\text { Cubic Feet. } \\
41\end{array}$ & $\begin{array}{c}\text { S. } \\
\text { Bavaria, . . }\end{array}$ & $\begin{array}{c}\text { Pence. } \\
4 \cdot 2\end{array}$ \\
Saxony, . . & 61 & $10 \cdot 4$ & 4.5 \\
Würtemberg, . & 64 & $21 \cdot 2$ & $5 \cdot 4$ \\
Baden, . . & 60 & 19.9 & 5.9 \\
\hline
\end{tabular}

1 Appendix xxxi, vol. ii. Minutes of Evidence accompanying Afforestation Report of Commission on Coast Erosion. 


\section{CHAPTER IX}

\section{THE STATE AND PRIVATE OWNERSHIP OF WOODS}

Throughout the whole of Europe about 30 per cent. of the forest area is owned by the State, and nearly as large a proportion by communes and corporations. The remainder is in the hands of private owners, who may or may not be under the necessity of maintaining it, according to the regulations in force in the various countries.

In Great Britain private ownership is almost universal at present, but it is unlikely that this will be always the case. The acquisition of forest areas by the State is being strongly urged, and is, moreorer, being practised to a limited extent. The purchase of Inverliever by the Office of Woods, and the transfer of estate woodlands to the Department of Agriculture in Ireland, are possibly only the first stages in an important movement towards the extension of State forestry in the United Kingdom.

Apart from the growing feeling in favour of State afforestation, municipal authorities are also dabbling in forestry to a greater or less extent, and provided they do not burn their fingers too badly in gaining experience, may do useful work in the future. The corporations of Leeds, Liverpool, Manchester, Glasgow, Edinburgh, etc., can point to a certain expenditure of money in this direction. The results as yet are small, and in some cases not too encouraging, but time has not yet had 
an opportunity of pronouncing its rerdict on municipal afforestation work.

To compare the respective methods of State, corporate, and private forest ownership is no easy task. The individualist would probably argue that all industries should be left to private enterprise, and that a demand for any commodity should always ereate a supply without State intervention. The collectivist would argue, and in this case probably with good reason, that a commodity which requires two or three generations to produce will never be adequately supplied by private enterprise. From their own points of view both are correct. An ideal forest area has sereral functions to perform. Some of these functions are best carried out by the individual to meet his own particular needs or ideas. Others, and especially those of a national character, can only be properly carried out by, or under the control of the State.

The planting of trees for ornament or shelter, and the supply of timber for purely local purposes, can be carried out most easily and naturally by the individual, provided certain facilities are given him. He knows, or should know, his immediate needs, the peculiarities of his soil and situation, and the most profitable way of utilising small patches of land unfit for any other purpose than timber-growing, better than any public body or State department. The neerls of a particular community or limited number of individuals, or of institutions or companies, may also be best met by direct action. The State can seldom study the needs of particular industries closely enough to suit all parties, while land in the hands of corporations or companies may serve a better purpose when afforested than when let at a low rent for agricultural purposes, although the nett yield may be slightly reduced thereby. State afforestation, on the 
other hand, must run on strictly economic lines, otherwise confusion and loss would eventually result, and the whole system be thrown into disorder and discredit.

But probably the most important difference between the individual and the State is the position of the former with regard to the planting and preservation of small areas and patches of land. As already stated elsewhere, the State, and to a certain extent the corporate body, must deal with areas of 300 acres or more if profit is the object in view. But the individual, who often plants trees for his own sake rather than with the idea of making money, can utilise odd corners, rocky knolls, or ravines for tree-planting which would otherwise lie waste and become an eyesore. This jdea is a very old one in Britain, and has lately been carried to its extreme limit by a society rejoicing in the somewhat high-Hown title of The Midland Re-afforestation Society, which has undertaken the task of planting the pit or spoil heaps of the Black Country.

The economic importance of shelter and ornamental trees has usually been ignored or disparaged. The timber they produce is often small, knotty, and defective in many ways. In field and hedgerows they may interfere with the operations of agriculture or the ripening of crops. By roadsides they may be a sort of danger in stormy weather, and the cause of slow evaporation from the surface in wet periods. All these objections may be made by persons of scrupulous economy who believe the world was made to make money in. With all due respect to these authorities, however, it may be pointed out that the civilised world is usually made up of many features which are not strictly economic, while others are positively wasteful. Yet both classes are considered the accompaniments of civilisation and refinement. A moderate number of ornamental trees in any country is 
a necessity if its landscape is to be made attractive, and the land a pleasant place to live in, for only the very poor or very ignorant live amid ugly surroundings.

Shelter and ornamental planting is generally supposed to have no direct value to any one but the owner of the land, and for this reason one seldom hears any suggestion made that the man who plants a specimen or hedgerow tree, shelter belt, or clump is adding to the wealth or wellbeing of the nation. Yet in most cases it is impossible to plant judiciously, whether on a large or small scale, without benefiting the country at large. There may be districts in which trees are already in excess of those actually required for ornament and shelter, and planting may not there constitute a virtue, although it is too rare to be considered a vice. But in a bleak, wind-swept country every man who plants a tree is doing something to convert that country into a comparatively sheltered and attractive land, and what is of more importance in the eyes of most people, he is increasing its capital value at the same time.

Take any farm or estate in Great Britain, and one finds its value, other things being equal, in direct proportion to the size and quality of the timber it contains, not merely because this timber is a marketable commodity when cut, but chiefly on account of the shelter and natural beauty it affords, and the increased fertility of the pasture and arable land which it surrounds. It is sometimes said that well-sheltered land is worth from 50 to 100 per cent. more than bleak and exposed ground. Probably the exact increase in value cannot be put into figures, but no one doubts that the increase is there, and in the event of the land being sold or let, its value becomes apparent. For stock-raising it is a well-known fact that shelter belts of some kind are indispensable, not merely for the shelter they aflord to cattle, but for 
the early growth of grass they bring about in spring. The extra bite of grass within 50 to 100 yards of a wood or belt in the month of March or April is worth more to the stock-owner than three or four times the quantity in June or July, when the grass in an ordinary season is plentiful everywhere. On arable land in windy districts belts are necessary to prevent the shaking out of the corn when it approaches maturity, although they may not be of such general adrantage here as on grass farms.

The landscape effect of shelter-planting on an adequate scale, and with the use of suitable trees, is also of some commercial value. This improvement is enjoyed by the country at large, for although an owner may not throw his land open to the public, the latter undoubtedly lose or gain by the general appearance of the district in which they live, and especially so in districts used for country residences, such as the suburbs of large towns. Some of the most beautifully wooded districts of the present day are found in the older suburbs of towns which have not been too much encroached upon by shops and factories. Pleasure resorts, again, are invariably well wooded, and even in the heart of London, parks and squares can show a greater wealth of sylvan beauty than many parts of Scotland, Ireland, or the north of England.

It cannot be denied that in these instances the public benefit to a very great extent. Public parks are, of course, maintained by public money, and are free to all; but the trees of private gardens and grounds add greatly to the beauty of a district, and every one shares in the enjoyment to be derived from them. While the wealthy man may fill his house with art treasures, or his garden with expensive plants, and in neither case benefit the man in the street or country in the slightest, he can scarcely 
monopolise the whole of the benefit secured by tree-planting. This work, therefore, stands in a somewhat different category from inost operations associated with private enterprise, and deserves encouragement in a more practical way than that usually extended to individual effort.

It, is true that individual effort can never be replaced by public authorities. But the amount of planting which takes place when special facilities are given must be greater than when these are absent, and it is clearly the duty of those in charge of public aftairs to interest themselves in providing such facilities as will enable every owner of an acre of land to plant a few trees, or the owner of 100 acres to plant an acre or two if he desires. It may be urged that public nurseries and average intelligence enable any man to procure trees and plant them, and nothing more is necessary provided the will to plant exists, but experience proves that these agencies are insufficient in poor districts. The small farmer or landowner has a very scanty linowledge of species and their suitability for different soils and situations. He has, as a rule, little money to spare in experiments and speculative undertakings. And he is often content to take things as they are, and trouble himself little about improvements which are not of immediate benefit to him or his home.

In wealthy districts in which abundance of shelter trees already exist, no necessity may arise for such assistance in this work. In most districts in the south of England and Nidlands hedgerow trees are in sufficient numbers to supply all that is needed in this direction. In picturesque districts the attractions offered to men of means and leisure result in the creation of a large number of small estates, and planting on these is practically universal. Lurere residential estates in the hands of wealthy owners have been usually well cared for in the past, and it is only 


\section{THE DEVFLOPMENT OF BRITISH FORESTRY}

occasionally that a scarcity of trees is noticed in any of these cases.

But the fact must be recognised that a large proportion of the land of the British Isles is slowly but surely being broken up into holdings of small or moderate size, and occupied by men who have little time or spare capital to spend on the provision or renewal of shelter trees. The territorial inagnate who looked upon half a county as under the shelter of his patronage and protection no longer exists in a general way. The tendency on small estates at present is to curtail all expenditure to the actual demesne or park in which the owner resides, leaving tenanted holdings and land not immediately under the eye of the proprietor to be dealt with on strictly economic lines, and restricting all expenditure to the lowest point.

So far the effect of these changed views and conditions bas not been seen. Trees which were planted or preserved in hedgerows, belts, and clumps from fifty to a hundred years ago still exist for the most part, but every storm, every purchase of a farm, and every change in land legislation reduces their number, and little or nothing is being done to replace them. Unless this omission is rectified in some way, many parts of the country will soon present an appearance not far removed from a treeless prairie. Whatever the economic aspect of such a change may be, the resthetic effect cannot be otherwise than deplorable in many districts which are entirely dependent upon trees for any break or variety in the landscape.

It is evident that the only remedy is to provide smaller owners and occupiers of land with certain inducements and facilities for judicious planting. Inducements may be provided in the education afforded by contrast and example of the benefits to be derived from planting; facilities must be furnished for obtaining 
cheap and suitable trees; and in both of these directions nninicipal, district, and county authorities can do much good if they go about it in the right way. The main point is to aroid unnecessary expense and waste, and to ensure that the expenditure of public money is confined to work which the individual cannot do for himself. The county authorities, if required, can give advice and instruction in the planting of trees, and arrange for having the difficulies removed for obtaining them in a fit condition to plant. 'The former can be provided by instruction in arboriculture, just as instruction in agriculture or horticulture is provided in most districts now. The latter, without which instruction is more or less useless, can be best provided by a compromise between the commercial nursery as it at present exists, and special depots for growing on trees to the required size and quality demanded by the conditions under which they have to be planted. With the training now available for practical foresters in England, Scotland, and Ireland, there should be little difficulty in getting men fully qualified to act as instructors and demonstrators, and one or two of such men in each county would not be a serious drain on its resources. A precedent for their employment has already been provided in connection with agriculture, horticulture, bee-keeping, butter-making, and dozens of other industries no more important in a general way than tree-planting. A little extension of the encouragement given so freely to the above branches of rural economy, therefore, would not be unreasonable.

The growing of trees by public authorities is a more startling innovation, but one which would be absolutely necessary if success is to be achieved. By the establishment of depots or stocks of trees from which the small planter can supply his needs in sinall quantities as required, and without their having to undergo the weakening and 
deteriorating process so productive of failure and disappointment when carried long distances by rail, one of the most frequent causes of failure would disappear. 'The choice of trees to a man unfamiliar with even the common species of field and hedgerows can become so perplexing a process as to prohibit or retard many men from attempting planting. With the trees brought to the planter's holding, and the choice, or at any rate the number of species limited to those suited to the soil of the locality, two of the most important difficulties are removed, and the expenses of planting reduced to a minimum.

How many of these depots would be required in a county would greatly depend upon circumstances, but at the most from five to ten would be ample in the largest, provided proper means of distribution were adopted. 'Their management would be placed under the instructors, who would quickly be in a position to estimate the most suitable number and size required to meet the particular needs of each district.

The stocking of these depots could be carried out by obtaining trees from public nurseries, the chief difference being that, instead of planting them out direct, with all the attending disadvantages, they would stand in the local nurseries for one, two, or three years, according to the species and other circumstances. They would be selected and purchased by the instructors, who would overlook the whole business from start to finish, so far as this would be necessary.

Objections to the above scheme might be made in many directions, the chief being, perhaps, that private enterprise would be interfered with, and the possible loss involved in growing trees which might not be sold. As the trees would be purchased from public nurseries to begin with, there cannot be much risk of trouble in the former way. As regards loss, it is unlikely that the sale of trees 



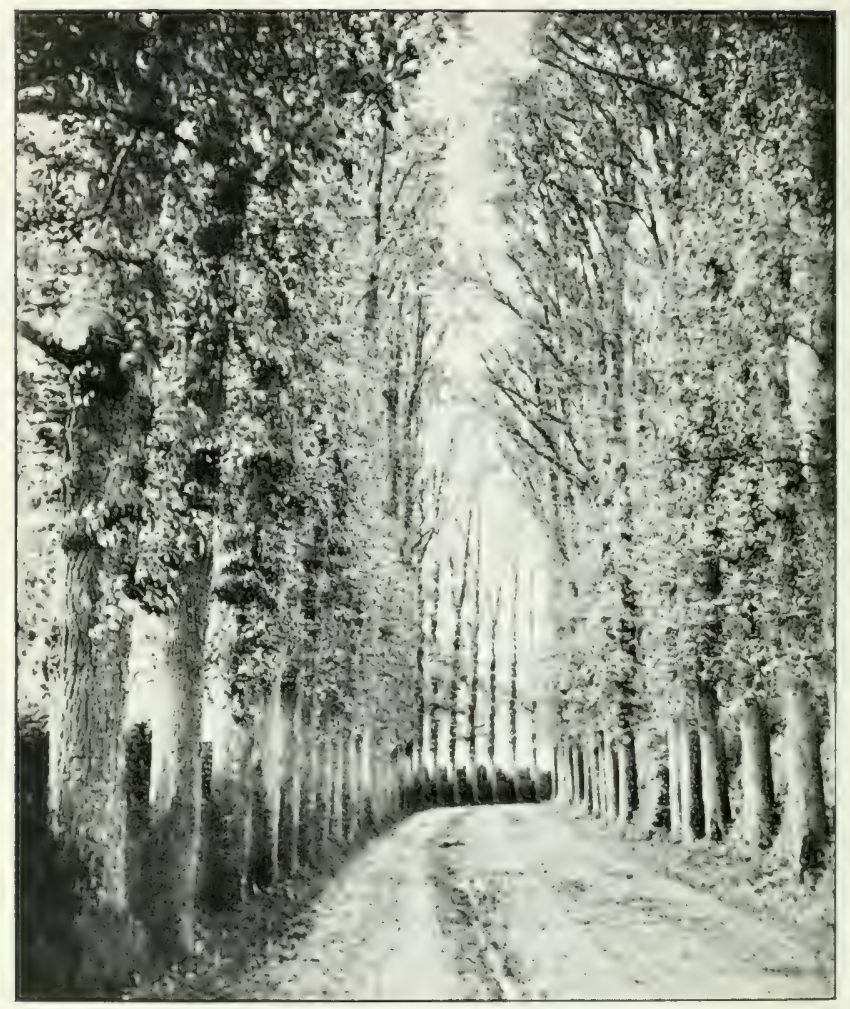

68. IVEnue of CORnish Elas. CORnwali. 
would cover the entire expense of working the various depots, but the disposal of surplus stock could be easily arranged by planting it on spare ground throughout the county which is now lying waste and unenclosed, or on land purchased direct for the purpose. With proper organisation, however, little loss from any direction need be apprehended. There is, of course, a danger of red tape and ofticialism being the cause of extravagance in certain directions, but this would soon right itself. Nervous ratepayers might, for instance, conjure up a vision of a highly paid tree inspector touring a county in a motor car at their expense. Calling at the small farms of men who have planted half a dozen trees, this official, with the dignity of a bishop and the autocratic air of a fieldmarshal, would issue peremptory instructions to move a pigsty ten yards from one tree, close a field in which another was planted against grazing for the next ten years, and prescribe some troublesome and expensive course of treatment for a third. The final result might be an expense of ten to twenty shillings for every tree that was planted, and a gradual determination on the part of the poor planter to cease taking advantage of the scheme, if only for the purpose of getting rid of the annoyance of inspection.

Experience of similar work elsewhere, howerer, would lead one to anticipate little trouble in this direction. The work done by the Heath Societies in Denmark and Holland is a striking and eloquent testimony to the results which can be oltained by aftording the small landowners advice and assistance in shelter-planting. In Jenmark, the Heath Society, chicfly working on the wind-swept soils of Jutland, undertakes the entire operation of planting belts and swall woods, varying from one to twelve or thirteen acres in extent, the owner subsequently paying two-thirds of the cost. This society receives an annual subsidy of $£ 20,000$ from the Danish 
government, and has been instrumental in adding some 150,000 acres to the woodlands of Jutland within the last fifty years. Somewhat similar work is carried out in Holland, Schleswig-Holstein, etc., proving that a bleak country can be transformed into a sheltered land within a comparatively short time.

With schemes of the kind described above on foot, a marked improvement in the landscape of many districts would result in the course of a few years. Shelter belts, clumps and woods of two or three acres in extent, if planted with wind-resisting species as the main crop, like silver fir, sycamore, Corsican pine, beech, ash, etc., would produce commercial timber of some value, and probably sufficient to meet the requirements of many rural districts in fencing, firewood, rough-hewn timber, and wood for implements and other articles.

It is, perhaps, not so easy to say very much in favour of hedgerow trees alone from an economic point of view, for they are not only expensive to plant, but their existence on arable land undoubtedly does a certain amount of harm. But on pasture land in the south, midlands, and west of England, one species has certainly put hundreds of thousands of pounds into the pocket of the landowner, not only without doing the farmer much harm, but in some cases a good deal of good. This species is the English elm, a tree which has renewed itself for many centuries from suckers, and forms one of the most picturesque and characteristic features in most districts in the southern part of England. But with judgment and skill even hedgerow trees may be planted in such a manner as to inflict no loss upon the surrounding land or crops, or upon the owner beyond the direct outlay involved in planting the land. To the actual planter a direct return is seldom possible, but regarded as an investment the planting of small clumps and hedgerow timber may prove 
a sound financial transaction, provided suitable species are used for the particular soil and situation. All land, whether farms or residential estates, increases in value when sufficiently timbered, and no form of improvement is more universal than the planting of shelter belts and tiwber trees on estates which are being laid out for residential purposes.

The most usual form, however, in which private enterprise is found associated with forestry is that of the ordinary estate woodland, of which some $3,000,000$ acres exist in the British Isles in individual woods, which vary from two or three to several hundred acres in extent. This type of wood is too well known to require describing, and has been fully dealt with in another work, ${ }^{1}$ but the relation between these woods and the State is a subject on which much might be said. A reference to the following table shows that private ownership of woods in all countries is a common, and usually a prominent feature.

Ownership of Forest Areas in Percentages of Total Areas in Principal European States

\begin{tabular}{|c|c|c|c|c|c|c|c|}
\hline \multicolumn{4}{|c|}{ Country. } & \multirow{2}{*}{$\begin{array}{c}\text { Total } \\
\text { Forest } \\
\text { Area. }\end{array}$} & \multirow{2}{*}{$\begin{array}{c}\begin{array}{c}\text { State or } \\
\text { Crow n. }\end{array} \\
\text { Percentage. }\end{array}$} & \multirow{2}{*}{$\begin{array}{c}\text { Communes } \\
\text { or } \\
\begin{array}{c}\text { Corporate } \\
\text { Bodies. }\end{array} \\
\text { Percentage. }\end{array}$} & \multirow{2}{*}{$\begin{array}{l}\text { Private } \\
\text { Owners, }\end{array}$} \\
\hline & & & & & & & \\
\hline Russia, & . & - & & $516,000,000$ & 60 & 10 & 30 \\
\hline Sweden, & . & - & . & $48,0 \cup 0,000$ & 20 & & 80 \\
\hline Norway, & . & . & - & $17,000,000$ & 12 & 3 & 85 \\
\hline Germany, & . & - & - & $34,569,000$ & 33 & 15 & 52 \\
\hline Austria, & - & . & . & $24,162,000$ & 7 & 10 & 83 \\
\hline France, & . & . & . & $22,224,000$ & 10 & 22 & 68 \\
\hline Hungary, & . & - & . & $22,224,000$ & 16 & 52 & 32 \\
\hline Britain, & - & - & - & $3,030,000$ & 3 & $\ddot{0}$ & 97 \\
\hline Belgium, & . & . & - & $1,215,000$ & 5 & 35 & 60 \\
\hline Denmurk, & & . & - & 682,000 & 24 & $\ldots$ & 76 \\
\hline Switzerland, & & . & . & $2,118,000$ & 6 & 66 & 28 \\
\hline
\end{tabular}

1 English Estate Forestry. 
It would appear that the more highly a country is developed the greater the natural tendency for private woods to take the place of those owned by the State. That is to say, the country becomes in course of time so utilised, that private ownership of small blocks is a much more prominent feature than State ownership of large undivided areas. This tendency is the more marked in densely populated countries, in which the competition for land increases, and the higher value put upon it induces the owner, whether the State or the individual, to turn this fact to account by renting or selling the more fertile part to those able to pay the highest price. In this way all large blocks of land, whether forest or waste, are gradually broken up, and the longer the process has been going on the more difficult it is to find large areas of any one type of land in the hands of one owner.

In many cases, however, the natural tendency to split up land has been retarded or prevented, and notably so in the case of forests. Only in Russia, Sweden, Norway, etc., in which the forests may be considered as virgin waste, is it found that State-owned forests predominate in a purely natural or spontaneous form. In nearly all other European countries the percentage of State-owned woods seldom exceeds 30 per cent. of the total, and is then only maintained by an energetic process of conservation, and resistance to encroachments which has been brought about by strong measures. In mountain districts physical reasons exist, as already stated, for the restriction of other forms of industry, but in the lowlands it is invariably found that the division of land has proceeded at a more or less rapid rate, and this has undoubtedly tended to throw woodlands into the hands of small estate-owners, and to restrict them to inferior patches of soil unsuitable for other crops.

But although large areas of woods hare passed out of the 
hands of the State in this way, many countries have passed laws which still recognise private woods, so far as the land is concerned, as State property, although the timber they produce, and the transfer value of the land may be vested in the individual. Regulations for the management and control of private woods are common in most European countries, especially in those with forests corering mountain-sides, which may be in danger if the former are removed. In Great Britain, on the other hand, the owner is allowed to do practically what he likes with his woods, and instead of encouragement being given him to keep them in good order, taxation and legislation rather tend to the opposite result.

To a very great extent private woods should be considered as that portion of the wooded area of a country which consists of individual woods too small and scattered for the State to hold and economically supervise, for reasons already given. Regarded in this light, it is clearly the duty of the State to concern itself with their management and continued existence. To leave private woods to the mere chance of being properly cared for by life owners or temporary owners of estates is little short of criminal negligence, assuming that woods are a necessary feature in a civilised country. Most of the civilised nations of Europe have come to the conclusion that they are necessary, and it is equally clear that they can neither be entirely provided by State agency on an adequate scale, nor distributed over the country so uniformly as to enable all parts of the community to benefit. The co-operation of the individual is as necessary in national forestry as in the creation and development of industries, and the idea that the State can entirely take the place of the individual wood-owner is equally as alsurd as the idea that the latter can succed without the assistance of the State.

One of the weakest points in the Afforestation Report 
of the Royal Commission on Coast Erosion was the ignoring of this fact. A huge scheme for the State afforestation of 9,000,000 acres of land was sketched out, but the part which the private planter would be absolutely bound to take, if that scheme ever reached fruition, was not even referred to. The one agency is as necessary as the other, unless modern economics are to be ignored altogether, and land acquired quite independently of its agricultural value, and the methods already employed for utilising it.

The Departmental Committee on Irish Forestry clearly recognised this point in their report, and calculated that private woods in a country of small holdings, such as Ireland, must constitute at least 60 to 75 per cent. in any scheme of afforestation. Whatever the actual proportion may be, however, it is evident that the more divided the country, the greater the preponderance of relatively small and isolated blocks; for whilst it is comparatively easy for the State to acquire the entire property of one landowner, it is very difficult for it to take up a number of small properties in proximity to each other, and form them into a compact block. In Great Britain and Ireland private woods are likely to remain the prevailing form of forest for many years, however energetic the process of State afforestation may be.

Until within recent years, however, practically no assistance has been given to the private owner in improving and developing his woods. For a period of two hundred years British forestry has been slowly evolving from the primitive methods followed in the seventeenth century into a practice rather than an art or an inclustry. Customs and methods were founded on traditions, personal ideas, and empiricism rather than collective experience and logical deduction. As soon as the forest or the waste ceased to become public property its management became merely a matter of chance on the part of the owner, and 
the ideas of one man were invariably replaced by others when his successor came on the scene.

The only great change made in the British forestry of to-day from the practice of a hundred years ago is due to the introduction of exotic species, which has enabled the modern planter to get the greatest variety into his woods, and discover, by a process of elimination, the fittest for economic conditions. In this respect Britain may be regarded as having given a lead to the Continent, while the latter has given, in return, numerous hints but very few lessons capable of application on a large scale. The most marvellous thing about British forestry as it existed fifty years ago was its comparative success, bearing in mind the chaotic conditions under which it had been produced. The mistakes which were, and are, being made, may be traced not so much to faulty knowledge and methods, as to lack of organisation, and the personal influence and financial requirements of a constantly changing series of owners, most of whom have other objects in view than the growing of commercial timber.

On the Continent much the same state of affairs might have existed had not the State stepped in, and by force of example on the one hand, and mild forms of encouragement and compulsion on the other, brought private woods into line with economic principles. In Great Britain the State did practically nothing until the end of the nineteenth century to improve the condition of private woods. Even the few examples it afforded in the shape of Crown forests were rather objects of ridicule than otherwise, and the last thing a proprietor or his forester thought of doing was to follow the antiquated methods of Crown forestry, and its alsurd attempts at growing oak-for the navy on perfectly hopeless soils.

'The first important reform morcment concerned India 
more closely than Britain, but the fact that the Indian Forest Service was filled and recruited by Britishers doubtless had an indirect influence on public opinion in this country. Since about 1860, when Cleghorn and Brandis inaugurated the Indian Forest Service, a small stream of continental trained youths has been going out to India, and an equally small stream of retired Indian foresters, on furlough or pension, has been returning from it. Whatever the exact practical results of this interwixture of British and Anglo-Indian ideas may have been, there is little doubt that fresh ideas were instilled into British foresters and proprietors, and a wider knowledge of forestry as an industry instead of a hobby resulted.

The first indirect step towards public assistance to British landowners was the establishment of a forestry lectureship in Edinburgh University, which was ably filled by Dr. Somerville in 1890-1891. This inaugurated the system of forestry education which has gradually extended into some dozen centres in Scotland, England, and Wales, including the Universities of Oxford and Cambridge. Combined with this instruction has been the provision of cheap advice to landowners, a step which is likely to lead to results which cannot be fully seen for many years, and which will largely depend upon further assistance and encouragement from the State.

But another form of education, totally unconnected with the State, has also had a very great and probably lasting effect upon British forestry during the last fifty years. This consists in the constant visits made by the British landowning class to the Continent in search of pleasure, sport, or health. These visits, although totally unconnected with forestry, perhaps, can scarcely have failed to open the eyes of landowners to the possibilities of scientific forestry, and some of the seed thus sown will probably lear good fruit. Under the auspices of the 


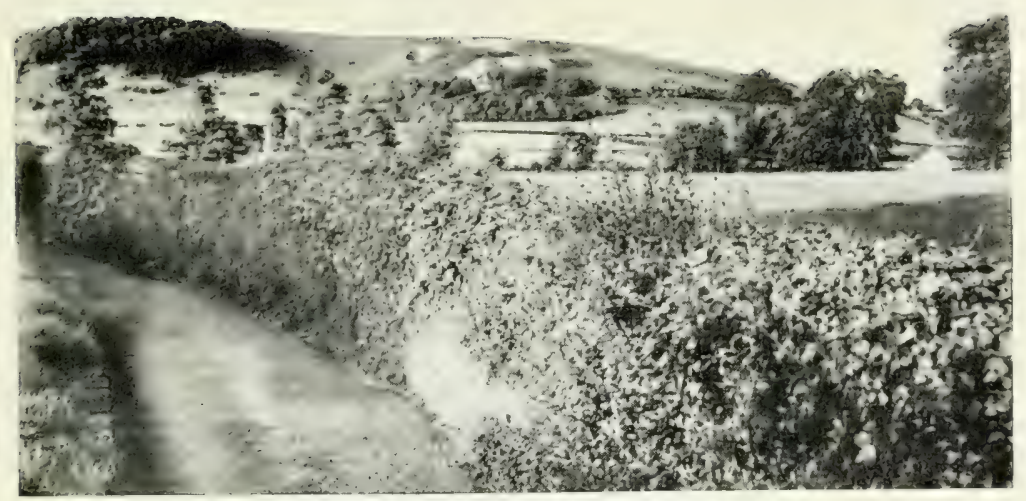

69. ARTFICIAL AXD NATURAL CLUMPS ON CHALK IOWNS.

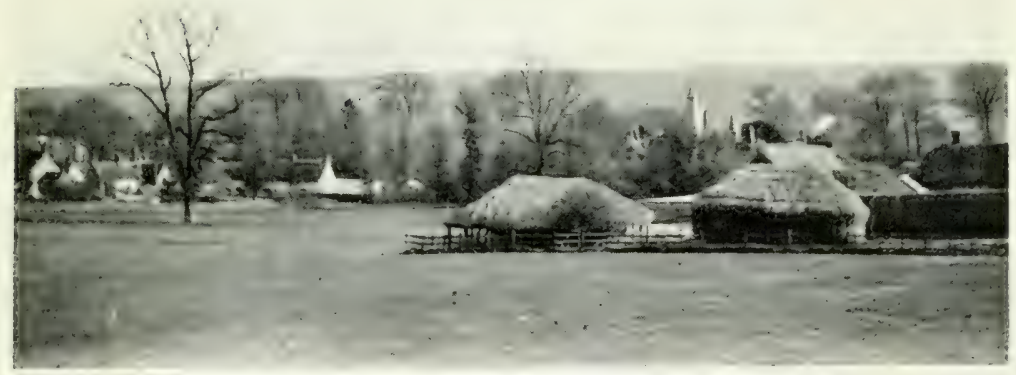

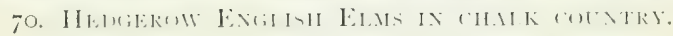

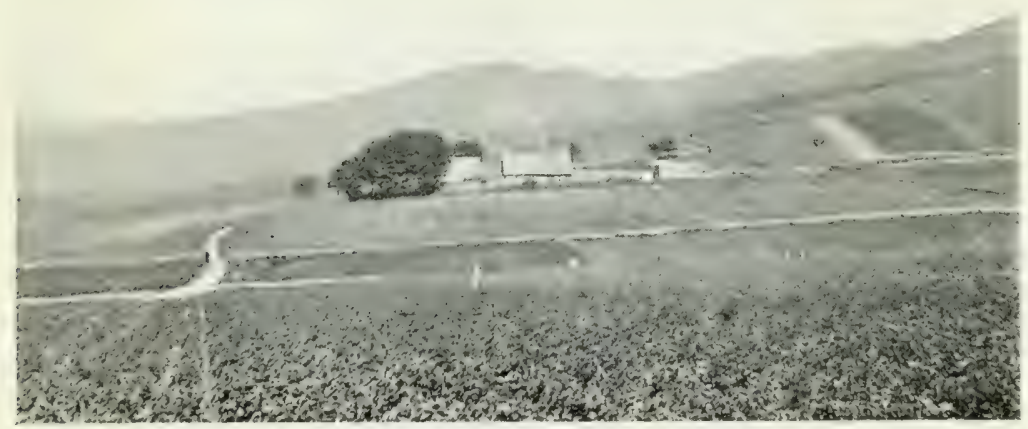

71. MOUNTAN FARM IX WEST HIGHLANISS. 

Royal English and Scottish Arboricultural Societies, proprietors, land agents, and foresters have, within the last twenty years, visited France, Grrmany, Belgium, Denmark, and Sweden, resulting in a widening and illuminating effect upon the general opinions prevailing amongst those classes. Then the influence of the societies already named must not be overlooked. Founded in Scotland in 1854, and in England in 1881, these societies now possess a membership of considerably over two thousand persons. By means of their publications and excursions they may be regarded as the heart and brains of the professional forestry world in Britain, and have had much to do with any assistance rendered by the Board of Agriculture and the Office of Woods to forestry in recent years.

With a few unimportant exceptions, perhaps, the above steps constitute the only assistance British owners of woods have received from outside sources, and the greater part of it has been derived from private rather than State agencies. In fact, many reasons might be given for the statement that State interference with woodlands, in the form of legislation, has rather been of an adverse than a favourable kind. Instead of helping the owner of woods to develop and improve them, several measures passed within recent years have increased his difficulties, although indirectly rather than directly.

The most unfavourable effect upon wood management has been produced by the Death Duties imposed in 1894. Nearly all forms of taxation tell indirectly upon private forestry, and it is difficult to see how it should be otherwise. Trees after reaching the pole or small timber stage possess a value of some kind, and an owner wishing to make money to meet certain contingencies, or sudden calls upon his purse, is not likely to discriminate very clearly between a ripe and unripe timber 
crop, or between a tree which is still increasing in size and vilue, and another fully mature. The fact that both or either are worth money is sufficient reason for their boing cut when funds are required. Death Duties being levied at irregular intervals are almost certain to disorganise estate work generally, and the woods probably more than the remainder of the estate. Even insurance against risks of this kind, or payments deferred until the crops are realised, do not prevent the inconvenience arising from them altogether, and each change of ownership invariably disturbs the regular working of woods, which is so essential to their being maintained in a satisfactory condition.

Many complaints about the rating of woodlands have also been made in recent years. It is contended that young woods should escape taxation altogether, as they are not in a position to yield revenue for many years after they are planted. It is also urged that those in full bearing are assessed higher thim they should be. The subject is too complicated to be discussed in a mere sketch of the disabilities of private woodland tenure, but it is possible that too much importance is attached to the effect of rates upon the well-being of woodlands.

Naturally, all taxation, whether imperial or local, is unpleasant to the man who pays, but no reasonable individual really objects to contributing his fair share towards the public purse. To an estate-owner it matters very little in the long run whether the amount he pays is levied on one part of his property or another, provided the total does not exceed the proper sum. If woodlands are assessed on a lower scale than at present, some other form of property must be assessed on a higher scale to make up the required sum. To the owner of an estate consisting of woodland chiefly or entirely the above point may be of importance. To the average estate-owner in this country, however, a shilling more or less on the rateable 
value of a wood cannot have very much effect on his nett income, and the latter is the factor which influences his policy in forestry matters more than any other. With rates at $2 \mathrm{~s} .6 \mathrm{~d}$. to $5 \mathrm{~s}$. in the $£$, and an assessinent of $2 \mathrm{~s} .6 \mathrm{~d}$. to 5 s. per acre, which are about the average figures in the British Isles, it can scarcely be stated that rates offer a more serious obstacle to profitable forestry than any other features. For the planter it is certainly a grievance to have to pay rates on woods under twenty years of age, but this could only be equitably avoided by a special grant being made to districts and counties to make good the loss, or by progressively assessing the wood at a higher figure as it adranced in age and value. Against the former there can be no objection outside the British Treasury, but the latter plan would appear to lead to endless confusion, for no assessment committee or valuer could place an exact value on a growing wood. An automatic increase of assessment with age would be equally as unjust as the present system.

The best of all methods is probably that adopted in Ireland, where the assessment is based on the government valuation of the grazing value of the surface soil, and every one accepts the decision arrived at without a murmur, and without the constant annoyance arising from the attempts of the owner to lower the value of the land, and of the assessment committee to increase it. The land valuation clauses of the 1909 Budget may lead to this system becoming general, and the sooner the better if a moderate valuation is agreed upon which takes fully into account the low nett returns received from woods. No system of assessment can be absolutely uniform and absolutely just to the individual at one and the same time. Good land may be carrying a worthless scrub, which, in the owner's eyes, should not be rated at all. Inferior land, by judicious planting and management, 
may be carrying a valuable crop. It is scarcely a greater hardship for the owner of the former to pay on the produstive capacity of the soil, than for the latter to pay on land rendered valuable only by good management. In the case of woods, the worthless crop may not be the fault of the present owner, but it is clearly the fault of his predecessors, and it is hard lines for the industrious members of the community to be compelled to pay higher rates on productive or well-managed land to make good the shortcomings of their improvident or thriftless neighbours.

Apart from rates and taxes, which may be considered inevitable drains upon woodland property, the condition and financial prosperity of private woods depend very largely upon the interest taken in them by their owners. While the State cannot directly influence every landowner in the British Isles, or compel him to do his duty with respect to woods, there is little doubt that a sympathetic attitude towards the inevitible difficulties which meet every owner in his desire for improvement and development would do a great deal of good. Educational facilities for both landowners and foresters have now been provided on a fairly liberal scale, bearing the fact in mind that the opportunities of turning to account the education acquired are as yet few. Advice can be obtained free on a number of matters relating to practical forestry from the agricultural boards and departments in England, Scotland, and Ireland, while forestry experts exist by the score in nearly all parts of the British Isles.

What is now wanted are more immediately practical forms of assistance, which would enable an owner to bridge over the personal loss which he incurs in planting new or improving old woods. Loans at a low rate of interest appear to be the readiest and most appreciated 
form in which assistance can be given, as they enable an owner to plant with the smallest immediate outlay, and a subsequent ammual payment of interest and sinking fund is not so much felt as the payment of the total sum at the outset.

In Great Britain provisions are already made under the Improvement of Land Acts, etc., by which loans are granted to companies for periods of twenty-five or forty years, repayable by annuities varying from 5 to 7 per cent. respectively, and bearing interest at $3 \frac{1}{2}$ to 4 per cent. Similar loans are granted by the Board of Works in Ireland. Little advantage has, however, been taken of these loans for planting purposes, not quite $£ 100,000$ having been advanced since 1564 in England, and a much smaller sum in Ireland. Whatever the reason for this may be, there is little doubt that the interest charged is too high, and the period of repayment too short. No private owner can afford to pay 4 per cent. interest on capital invested in his woods, and obtain a profit at the end of the rotation, and while he may possibly borrow for shelter-planting, or to produce game cover, it is scarcely probable that he would burden his estate with a dead-weight charge of possibly $10 \mathrm{~s}$. per acre in perpetuity, assuming that the annual loss incurred on the capital outlay amounted to that surn.

To plant by means of these loans is, therefore, bad finance, if nothing more. No loans for forestry purposes should bear interest at a higher rate than $2 \frac{1}{3}$ per cent, with an additional $\frac{1}{2}$ per cent. for sinking fund. This wonld spread the loan practically over the life of the crop, and however impossible loans at such rates might be to a private money-lender, they are certainly possible to the State. If a little loss were involved in making them, it should be regarded as a premium 
granted to encourage private forestry, and when combined, as they should be, by the periodic inspection of the woods by a qualified forester, a system of good forestry would gradually be built up in the country which would not fail to be of benefit in the long-run.

Another form of assistance found useful on the Continent is that of granting a bonus to planters, amounting to about 50 per cent. of the cost of planting. Compared with loans, this form of assistance might provide greater inducement to an owner to plant, but it seems better adapted to the small farmer than the larger landowner, or to the planter of waste land which has never before borne a crop of timber. Loans or premiums, however, given without further investigation or subsequent inspections are apt to lead to bad results. The mere fact that a man has been able to plant a few acres without putting himself to much trouble or inconvenience, may lead to carelessness or neglect in the future treatment of the crop. This need not, nor would it be the case in all instances, but the mere granting of money for bad and unproductive work should be carefully guarded against, and the recipient of a loan or premium should be compelled to accept the advice, and carry out the instructions of a trained forester, until the loan is repaid, or the premium paid over. The latter, in any case, should seldom be given until two or three years after the commencement of the work, and until its completion in a satisfactory manner.

The third and last form in which the woods or tree growth of the country may occur are State forests, managed chiefly with a view to supplying an adequate stock of timber for the industrial development of the country, and also to utilise land which cannot yield a high return when under agricultural crops, or employed for the grazing of cattle. 
The functions of the State in forestry matters is clearly that of supplementing private supplies of timber to an extent necessary to meet industrial or special needs, and to ensure a continued and well-managed area of woodland for all time. This may be done by State or Stateaided forests, the one demanding land and the investment of public money, the other leaving the land in the hands of the individual, but aiding its development by education, advice, supervision, and the loan of capital if necessary, as described above. In all well-balanced and developed countries State and private forestry not only exist side by side, but the one aids and strengthens the other. The idea that the State, by planting and holding woods, is usurping the rights of the individual is totally erroneous. In an ideal community there is good reason to suppose that each man would do his duty in maintaining wooks as in other duties which make for the public good, but so long as human nature is what it is, too much must not be expected of the individual, and forestry is one of those industries which is apt to decline when personal inclinations and conditions run counter to it. While the State can, or should, consider the future as well as the present, the individual obviously regards the latter as of greater importance, and no one can naturally expect him to do otherwise.

In Britain the only State forests are some 50,000 acres of woods in England, a few hundred acres in Wales and the Isle of MIan, 13,000 acres of plantable lind in Scotland, and about s000 acres of woodland in Ireland. Small as the area is, it is of great importance as a nucleus for future operations, and only needs development on existing lines to do all that is possible in this country. With the exception of the English Crown woods, all the above woods are the product, so far as State ownership is con- 
cerned, of the last twenty years, the greater part of them of the last ten years. The English Crown woods, in the case of the New Forest, the forests of Dean and Windsor, and one or two others, are practically as old as the Crown of England itself, and certainly older than the existence of Great Britain as a nation. Their present condition enables one, therefore, to gauge fairly accurately the position which forestry has occupied in the State economy of the country, and it must be admitted that it occupies a very low place when compared with State forestry in most parts of Europe. With the exception of the forest of Dean, most English Crown forests were maintained for hunting purposes, and when the latter pastime changed its character to such an extent as to render them unnecessary, they seem to have been maintained more by tradition and custom than with any definite object in view. The forest of Dean, however, would appear to have been regarded as a source of oak timber for the British navy for several centuries, and one finds there a somewhat better condition of things than in the other forests of the Crown.

During the last twenty years, thanks largely to the personal interest and efforts of Sir Stafiord Howard, a little life has been instilled into the dry bones of State forestry in England, and the morement once started is bound to go on. Of greater interest, perhaps, to the public, although not of much greater importance than the progress above named, is the afforestation of waste lands. This subject has been well ventilated recently, chiefly in connection with the report of the Commission on Coast Erosion. The sylvicultural and economic aspect of this work has already been dealt with; all that need be discussed here is the agency by which it can be brought about.

In all countries with a State forest area of any size, 
special departments are entrusted with the administration and control of the financial and national policies adopted, according to the requirements of the country, and the existing conditions of land utilisation. Only in this way can the necessary attention and energy required for the successful derelopment of the scheme be obtained. A forest service attached to a larger State department is invariably overshadowed and suppressed by its head, and sooner or later becomes an apathetic and time-serving branch, without mind or driving force, swathed in red tape, and incapable of doing satisfactory work, or becoming a living factor in the national life.

The only semblance to a forest service which exists in Great Britain is the Oftice of Woods, formerly in charge of the lands forming the perquisites of the Crown, and now regarded as an Imperial asset. This department has in its charge, as already stated, about 60,000 acres of woodland, and forms, so far as size and importance goes, an adequate State forest department, if developed and improved. Hitherto the practical work in the Crown woods has been entrusted to officials with very little knowledge of the rule of thumb of practical woodwork as practised in Britain, and still less of the technicalities relating to economic forestry. These officials have naturally favoured a policy of inaction as far as possible, partly to conceal their own incompetence, partly to sare themselves a good deal of trouble, and only occasionally has a system of fitful clearing and replanting been adopted, which has slightly improved the economic condition of the timber crop in C'rown woods of late years. The general result has been that the ('rown woods of the present day are being worked at a loss, and are generally of much less benefit to the comntry than they should be. Committees appointed in the early part of the nineteenth century revealed the fact that, while the higher salaried 
posts were practically sinecures, the lower were tilled by a type of men not above increasing their moderate salaries by dishonest means. Paragraph 14 of the Report of the Select Committee on Crown Forests, sitting in 1854, reads :

'The division of responsibility between the Commissioners and the Treasury, established by the 14 and 15 Vict. c. 42, has not worked well. A surveyorgeneral of practical experience, the appointment of whom is provided for by the twelfth section of the said Act, should have the superintendence of the whole of the forests, which he should frequently visit, and be responsible for carrying out all necessary details, through competent deputy-surveyors under him. These deputysurveyors should also be practically acquainted with forest affairs, and the place of deputy-surveyors should not be given, as it sometimes has been, to persons wholly ignorant of the management of woodlands.'

Between indifference and neglect on the part of the superiors, and breaches of trust on the part of the subordinates, and a large measure of incompetence common to both classes, the Crown woods became a source of ridicule to the practical forester instead of an example of good forestry, and a young man anxious to improre his knowledge would as little think of going to the Crown forests as a farm pupil of going to the Highlands of Scotland, or the west coast of Ireland.

In recent years this department has, horever, given signs of life to the extent of stretching itself and yawning. The stretch resulted in the purchase of Inverliever, the yawn in the creation of a school for working foresters in the forest of Dean. Small as these eftorts are, they show the first indication of an active forest policy which may be something definite if vigorously pursued. Nothing more is needed than the improvement of the woods 
already in existence, the purchase of additional areas as opportunities occur, and the grading up of the official staff:

The first essential is the separate administration of the work of forestry from mines, buildings, quit and ground rents, and other forms of property administered by the office. The forests should be, as fortunately they are at present, in charge of an enthusiastic commissioner, and not divided between two as in the past, one of whom may not take the slightest interest in forestry, another be a keen advocate of a forward policy. The most important portion of the woods has sometimes been in charge of the former, and an insignificant fraction entrusted to the latter. Under such conditions no uniform or definite policy could be promoted, and it is absolutely absurd to find, as might easily be the case, a highly conscientious and zealous officer in charge of one forest, and the younger son of a peer, chiefly occupied in sport and frivolities, in charge of another. Such striking anomalies as these may not occur in practice, but there is nothing to prevent them under the present (or let it be hoped past) system of filling vacancies in the State woods, and it is obvious that it inspires neither confidence nor enthusiasm in those having the interests of British forestry at heart.

For much of the higher administrative work a thorough knowledge of scientific forestry may not be necessary, but a commissioner of woods should certainly know the difference between good and bad work, and be competent to criticise the general result of his subordinates' work. The chief duties of a forest commissioner ought to be the extraction of money from the Treasury, and its expenditure in purchasing and developing lands and woods. As the work progresses it may be found that a separate forest commissioner for England, Wiales, and 
S'cotland would be needed. The actual supervision of forest areas, however, should be entrusted to an officer, assisted by a general stalf, competent to deal with all questions of forest organisation and the general principles of sylviculture, and to supervise the technical operations carried out at the various centres. Such an officer or officers should have an intimate acquaintance with forestry in Britain, with all its local peculiarities, as affected by climate, geographical position, and economic conditions. Mere book knowledge, or an acquaintance with cut and dried methods adopted in France or Germany are of little value by themselves. A State forest policy, embracing various sylvicultural systems, must be built up very largely upon principles agreeing in many essential features with the forestry practice of North-TVestern Europe, but, on the other hand, differing from it so far as details are concerned. Labour conditions in Britain also vary from those in other countries, and these indirectly, if not directly, affect practical methods to a very large extent.

Another function of these officers demanding British experience would be the inspection and selection of land for afforestation. In theory this would suggest the carrying out of a complete survey of the United Kingdom, but it is doubtful if the practical value of such a survey would be very great, unless compulsory powers of acquisition were extensively employed, or except for the purpose of laying down a general scheme of afforestation. Estates, or parts of estates, come on the market from time to time, and the most economical method of purchase for the State would be to take advantage of the opportunities thus presented, buy up all likely properties, and resell the portions too valuable or too worthless for planting. The work of inspection involved in this process would in course of time constitute a general survey of the country by the officers employed, without the expense of collecting minute details 
which may have no practical value. Owners willing to sell at a reasonable price would find means of bringing the fact before the proper authorities in a suall country like Britain, and there are no unexplored wastes to survey and map.

With regard to the form and distribution of State woods, these must vary in different parts of the country. There is probably no better field in Europe for atforestation, as distinct from forest land already stocked, than in the West and Centril Highlinds of Scotlind, provided the work could be carried out on a comprehensive scale, leaving the more fertile valleys to the farmers, and the higher and useless ground to grouse and deer. The difficulties are there connected more with the existing divided ownership, thin with physical or econornic conditions. If the landlord and the State could come to some working agreement, by which the land could be leased to the State for a period of twenty years, and the work of afforestation carried out by the latter, the landlord might, at the end of the lease, either purchase the growing crop, or sell the fee-simple of the land to the State. By these means national forestry could be greatly developed at least expense to the nation, for in a national sense the name of the landowner is merely a figure of speech. The direct purchase of land by the state could be effected wherever favourable opportunities presented themselves, but to trust to this method alone appears to be too costly and uncertain to maintain a proper distribution of woodland throughout the entire country.

Forests raised on this plan must, of course, be managred on definite and approved lines, and not merely the work of planting, but the management of the crops, be subjected to control and supervision in the event of their repurchase by the estate-owner, while woods thus formed should be subject to compulsory maintenance. Objections to this control inight be raised, but have really little more weight, 
provided the control is kept within reasonable financial bounds, than those to existing regulations on sanitation and health as applied to houses and persons. Regulations in force for the upkeep of woods in foreign countries show that this control is not outside practical politics, and need not be objectionable or irksome in any way.

In many other parts of the country a different system must be adopted to produce the desired result. In some districts, especially those with small holdings or estates, the direct acquisition of comparatively small blocks of land is indicated, for in these the individual can do little beyond the planting of shelter and ornamental timber. Blocks of not less than 400 or 500 acres can scarcely be economically administered, but there is no necessity to stand out for too large areas in view of the present divided condition of many parts of the country. In Ireland, the breaking up of estates is enabling blocks of this size to be formed with little difficulty, as the demesne woods usually run to several hundreds of acres, and the addition of a little grassland to round off the boundaries is all that is necessary to create a compact block. This process will eventually lead to a widely distributed system of small State woodlands in that country, which will take the place of estate woods as found in Great Britain, and will perhaps meet the needs of the country in supplying commercial timber.

But where estate woods are likely to be maintained in any case the soundest policy is that of trying to improve them by the various forms of assistance outlined above. In the fertile and best cultivated parts of the country land cannot be economically obtained for further afforestation in any case, and the existing estate woods are not likely to be greatly increased in either size or number. In many cases, however, their present yield of timber could be certainly doubled or trebled by good management, and if public money could be devoted to bringing this about, it 
might be regarded as well spent, although no direct return to the State might follow.

Organisation on the above lines would quickly place State forestry on a satisfactory basis, provided a class of practical foresters were employed of the right kind. If the facilities now existing for forestry education are supplemented by demonstration forests, there should be no trouble in securing, by competition or selection, an adequate supply of well-educated young men for filling all the posts that are likely to be created under the most extensive scheme. These men should, however, be trained as foresters from the first by serving an apprenticeship for at least two years in well-managed woods, after leaving school at the age of sixteen to eighteen. After this apprenticeship, they should take a course of science at one of the university colleges, special attention being devoted to those subjects which underlie their profession, but let this part of their education be thorough rather than 'high.' With the satisfactory completion of this course candidates for public service should be drafted out as assistants on woodland areas, occupying much the same position as the Forst-Assessor in Germany, and working their way up to the higher posts as opportunities occur.

By the joint action of the small planter, larger estateowner, and State, British forestry might easily reach the level attained over the greater part of Europe in half a century, so far as system and organisation are concerned. For the production of high-class timber crops, and a nett profit per acre from State woods, at least a century must elapse, by which time ideas on many subjects connected with forestry will perhaps have undergone a change.

The distribution of a possible forest area of $7,000,000$ acres throughout the British Isles might be apportioned somewhat as follows:- 


\begin{tabular}{|c|c|c|c|c|c|c|}
\hline & \multicolumn{3}{|c|}{ State. } & \multicolumn{3}{|c|}{ Private Owners. } \\
\hline & $\begin{array}{c}\text { Existing } \\
\text { Area. }\end{array}$ & Increase. & Total. & $\begin{array}{c}\text { Existing } \\
\text { Area. }\end{array}$ & Increase. & Total. \\
\hline England, & . $\quad(00,000$ & 100,000 & $160,000(0)$ & $1,600,000$ & 500,000 & $2,600,000$ \\
\hline Wales, & - 1,000 & 100,000 & 101,000 & 180,000 & 200,000 & 380,000 \\
\hline Scotland, & 13,000 & $2,000,000$ & $2,013,000$ & 870,000 & $1,000,000$ & $1,870,000$ \\
\hline \multirow[t]{2}{*}{ Ireland, . } & . $|8,000|$ & 200,000 & 208,000 & 295,000 & 500,000 & 800,000 \\
\hline & 82,000 & $2,400,000$ & $2,482,000$ & $2,945,000$ & $2,200,000$ & $5,650,000$ \\
\hline $\begin{array}{c}\text { Approximate } \\
\text { Increase, }\end{array}$ & \multicolumn{3}{|c|}{$2,400,000$} & \multicolumn{3}{|c|}{$2,200,000$} \\
\hline
\end{tabular}

Assuming that the acquisition of the 2,400,000 acres of State woodland would be spread over a period of 100 years, and that the purchase price of the land averaged $£ 5$ per acre, an annual sum of $£ 120,000$ would be required for land purchase. Working expenses and management would average, throughout the whole period, about $£ 1,000,000$, beginning with the small sum of $£ 20,000$ or so, and gradually increasing with the area acquired. Allowing for contingencies, the average annual cost of a forestry scheme as outlined above would be somewhere about a million and a quarter, disregarding compound interest.

The capital value of the $2,400,000$ acres might be estimated at the end of the hundred years to be about $\mathfrak{£ 6 0}$ per acre for land and timber at present prices, or $£ 1+4,000,000$, and the annual yield about $1,000,000$ loads, worth, at present prices, again, 30s. per load, or $£ 1,500,000$, or about 1 per cent. of the capital value. The financial aspects of afforestation on the above estimate are, therefore, not particularly bright, but a rise in the price of 
timber of from 50 to 100 per cent.-a possible increase under present conditions of supply and demand-might invest such a scheme with quite a different aspect.

No doubt local conditions will affect the possibility of forest extension in the British Isles greatly. Parts of the country with large holdings, thin populations, and local climates not adapted for cultivated crops, afford much greater possibilities than when the reverse conditions obtain. The IVest Highlands of Scotland and many parts of Ireland and Wales have many physical features in common, but whereas in the former the cultivation of the land is reduced to the smallest possible area, and the resident population confined to a few large sheep farmers, shepherds, and keepers, the latter are more thickly populated, so far as agricultural land is concerned, than many of the richest districts in the United Kingdom. Whether these differences are due to natural or artificial causes it is difficult to say, but probably both have had something to do with them. National character, education, social traditions, and customs tend in one case to decrease the population on the poorer land, and in the other to maintain it at its normal level in spite of all drawbacks and hardships.

In the hill districts of Scotland and the north of England rural depopulation has gone on to an enormous extent, and the remains of small holdings and farms may be seen on every hillside. In Wales and Ireland depopulation in similar districts has not gone on to the same degree, and hundreds of poor holdings are occupied simply because they afford a home for the occupier, and not merely on account of the profit which can be inarle from the land. 'These difterences in personal motives, customs, and traditions have great influence upon the possibilities of forest development in the British Isles. In the larger sheep-rearing districts the absence of cultivation in any 
shape or form, and of the mixed stock of horses, cattle, sheep, and pigs, formerly kept on the small holdings which have disappeared, is telling its tale in the spread of bracken, heather, gorse, and other forms of useless growth, and grass is being exterminated or losing its value for feeding purposes. As time goes on sheep stocks must decrease under such conditions, and the land will be more easily obtained in large blocks for afforestation.

Short of a return to the high prices for mutton and wool, it is difficult to see how this trend of affairs can be avoided, thus enabling forestry to advance at the expense of stock-raising, and possibly to the advintage of the country generally, as pointed out elsewhere. In another direction it would also tend to reestablish, in a small way, holdings on the better portions of the land, owing to the increase in the working populattion which must accompany aftorestation. The duty of the State in these districts is clear, for none but the State can afford the heavy initial outlay necessary to establish forests on an adequate scale, or to place them on a permanent footing.

In more thickly populated and better utilised parts of the country, the private owner must be depended upon to do the greater part of the work connected with forestry development, if it is done at all, but the State must encourage and assist this work to a greater extent than in the past if progress is to be made, and economic results obtained. However enthusiastic the private owner may be on forestry matters, only very occasionally will one be found wealthy enough to ignore the sinking of two or three thousands a year in planting operations, and in mountainous districts a proprietor of an average estate would require to spend at that rate to make adequate progress. Whether he will do so or not, the future alone can show. 


\section{N D E X}

Acclimatisation, 114-117.

Afforestation, financial aspects, 82, 143, 219; possibilities of, 267, 268 ; relative value, $74-78$; reports, 66, 78, 250 ; systems in British Isles, 187.

Agriculture, relation to forestry, $59,68,75,76$; statistics, 63,68 , 86.

Alder, conditions of growth, 90, 117, 156, 194.

Arboricultural Societies, 253.

Area statistics, 247 ; in Belgium, 8 ; Great Britain, 21; Canada, 34; Europe, 21 ; Holland, 8 ; Norway, 25; Quebec, 38 ; Russia, 25 ; Sweden, 25, 35, 42 ; Switzerland, 20.

Ash, value of, 193, 206 ; conditions of growth, 92, 104, 108, 156, 164, $184,223$.

Assistance to woodland owners, 53, 250,253 .

Austria-Hungary, forest policy, 23 ; elevation statistics, 99 .

Banks's Pine, as nurse tree, 161.

Beech, value of, 157, 207; conditions of growth, $90,92,104$, 108, 112, 152, 184, 191.

Bedford estate, woodland returns, 228.

Belgium, forest area, 8 ; woodland policy, 23 ; deficiency of production, 22, 26.
Birch, conditions of growth, 92, 117, 184, 194.

Bosnia-Herzegovina, forest policy, 24.

Britain, forest requirements, 29 et $s q q$. ; cost of transport, 43 ; height growths, 98 ; imports, 30 ; neglect of forestry, 53, 60, 61 ; mountain land, 136 ; production, 29 ; private ownership, 52, 236 ; seasons, 90 ; afforestation systems, 187 ; waste lands 137 ; woodland features, 148 .

CANADA, statistics, 3 .

Cedar, 93.

Chestnut, Spanish, value of, 205 ; conditions of growth, 93, 115, 194, 203.

Climate, of continental stations, 92 , 94 ; Great Britain and Ireland, 87 et sqq., 106 ; hill districts, 94,95 ; influence on tree growths, 89 ; affected by forestry, 54,55 .

Climatic groups, 92, 93.

Coast Erosion Commission, Afforestation Report, 66, 78, 250.

Continental forestry practice, $\mathbf{1 5 0 ,}$ $151,152,164-166$.

Corsican pine, 158, 209; conditions of growth, 104, 113, 184, 194.

Crown forest management, 260-26:3. Cupressus macrocarpa, value of, 211.

Danisit Heati Societr, 246. 
Dean, forest of, 260.

Denmark, forest policy, 23 ; consumption of timber, 21.

Death Duties in relation to forestry, 253.

Drought, effect on trees, 197.

Drainage of peat land, 140.

Douglas fir, value of, 204, 205.

\section{Education of Foresters, 243,} $252,267$.

Enclosure Acts, 61.

English elm, 246.

Estimates of possible forest areas, 268 ; of specimen blocks, 233, 234.

Europe, forest policy, 12, 51 ; area statistics, 21, 24.

Exotics in British forestry, 251.

Financial Aspects of AfforesTATION, 214 et sqq.

Finland, forest area, 37 ; wood exports, 37.

Forest, acreage in Europe, 21 ; causes of reduction, 4-8; destruction, 3,4 ; natural distribution, 1, 2 ; State control, 236 ; European, 6, 7; British, 9-11; Finnish, 37 ; Russian, 37, 47 ; Swedish, 41, 46.

Forestry, economic aspect, 13, 214, 239 ; continental nett returns, 227 ; general principles, 160 ; systems in British Isles, 187.

France, forest policy, 12, 23 ; wood imports, 22 ; height growths, 99.

Frost, damage to trees, 108, 197 , 198 ; intensity in Germany and Scotland, 120, 121.

Fuel wood, 26.

Fungi, injury by, 153, 199.

Grass, effect on trees, 184.

Grazing, influence on forests, 5, 6, 7. Germany, forest policy, 18, 23, 24, 27,39 ; wood imports, 22.
Greece, forest policy, 24.

Harz Mountains, tree growth on, 113.

Hazel, winter-Hlowering, 117.

Hedgerow trees, 246.

Height growths of trees, 98, 99.

Herzegovina, forest policy, 24.

Holland, forest area, 8 ; policy, 23 ; Heath Society, 245.

Howard, Sir Stafford, 260.

Imports OF Timber, 20-23，29, 30.

Improvement of Land Acts, 257.

Indian Forest Service, 253.

Insects, injury by, 109, 153, 199.

Inverliever, afforestation scheme, 84, 236.

Ireland, assessment methods, 255 ; Department of Agriculture, 237 ; Departmental Commission on forest policy, 250 ; timber consumption, 21.

JAPAN ESE LARCH, value of, 161.

July means of temperature, 92 94.

Jutland, planting in, 165.

KNockboy (Connemara), afforestation scheme, 146.

LAND, available for afforestation, $65,66,80$; leases, 265 ; value, 210, 220 ; purchase, 74, 83.

Larch, value of, 158,203 ; as nuise tree, 160; conditions of growth, 90, 101, 108, 154, 164, $189,223$.

Legislation $\%$ forests, 9 .

Lifting, 279.

Limestone, influence on tree gruwth, 1.24.

MAN, Isle of, afforestation trials, 147. 
Mayr, Professor H., on climate, 89, $\mid$ Planting, pit, 181, 182.

90.

Meteorology in relation to forestry, 91 et $s q q$.

Metzger, Dr., on Swedish forests, 35,36 .

Midland Re-afforestation Society, 238.

Mixtures, 154-160.

Mountain land, area, 65, 66; elevation, 136 ; planting experiments, $145,146$.

Municipal afforestation work, 236.

Natural Regeneration, 195, 196.

New Forest, 260.

Notch-planting, 181.

Nurse trees, 160, 161.

Nurseries, local, 185, 186, 243, 244 ; overcrow ding, 172.

OAk, value of, 191; conditions of growth, 90, 93, 112, 154, 225.

Office of Woods, 261.

Ornamental forestry, 57.

Ownership of forest areas, 247.

Packing for Transit, 179.

Peat-covered land, 132-134; formation of mountain, 144 ; planting on, 140-143; suitable trees, 144; on remains in, 143144.

Pine, Banks's, 161.

- Corsican, 158, 209.

- Scots, 208, 209.

Weymouth, 204.

Pinus insignis, 210, 211.

Pit-planting, 181, 182.

Plane, 93.

Planting operations, 77, 150, 168 ; cost of, 143, 221, 222 ; in Belgium, 166 ; Germany, 165 ; Jutland, 165 ; principles of, 169 , 178.

- notch, 181,
- slit, 176, 177, 180, 181.

Plough, use in lifting, 179.

Policy, forest, economic principles, 16 ; in Europe, 12, 21, 24, 27, 51,245 ; in India, 252 ; lack of, in British Isles, 62, 148.

Poplar, conditions of growth, 90, $117,156,184,194$; Black Italian, 211.

Preliminary expenses, 220.

Private owners of woods in British Isles, 52; assistance to, 250258.

Pulp wood, 34, 43 ; imports, 29.

QUEBEC, forest area, 38.

Quality of timber, 201-203.

RaINFAlL, 95-97.

Ramann on soil changes, 128, 129.

Rating of woods, $255,257$.

Regeneration, natural, 195, 196 ; under coppice, 119.

Returns from woods, 228, 230.

Robinia, seed-bearing quality, 194.

Roumania, forest policy, 24.

Royal Commission on CoastErosion, Afforestation Report, 66, 78, 250; reports to, 136.

Russia, State forestry, 37,47

Scots Pine, 208, 209.

Scrub forest, 2.

Seasons, planting, 178.

Seed, production of trees, 193, 194 ; beds, 178.

Selkirk, typical agricultural conditions, 73-76.

Silver fir, value of, 158,207 ; conditions of growth, 104, 118, 111, 152, 194, 207.

'Sheughing,' 180.

Slit-planting, 176.

Societies, Royal English Arboricultural, 253; Royal Scottish Arboriculural, 253; Heath, in 
Societies-continued.

Denmark and Holland, 245 ;

Midland Re-afforestation, 238.

Soils, 122 et $s q q$.

Sowing, in situ, 195.

Spain, forest policy, 24.

Spruce, Norway, value of, 207.

Spruce, Sitka, value of, 209,210 ; in

Canada, 34 ; conditions of growth, $91,95,101,112,152,154,164$, $194,223$.

State forestry, 259-270; advantages of, 18; German, 18; Russian, 37,47 ; Swedish, 35.

Sweden, forest area, 35, 42 ; policy, 35, 36, 45 .

Switzerland, forest policy, 12, 20, 21, 23.

Sycamore, conditions of growth, 93, 117, 156, 158, 164, 194.

Sylviculture, principles of, 155 ; systems, 209-210.

Thaxation, woodland, 254.

Temperature during summer months, 89-91.

Thuia gigantea, value of, 210.

Timber, consumption of, 14, 17, 20,23 ; economic value, 14,16 ; imports into Europe, 22 ; into

Timber-continued.

Britain, 29; prices, 27, 225, 236 ; production in Canada, 34 ; in Europe, 22 ; in Sweden, 36 ; specific value, 201.

Timber Irades Journal, extract from, 39-5l.

Transplanting principles, 169-178.

Transport, cost of, 33, 43.

Trees, hedgerow, 246.

United States, forest policy, 27.

Value of Agriculatural ProDUCE, 64 ; land, 70 ; timber, 224.

WaLNuT, 93, 194.

Wastes, enclosure of, 61.

Weymouth pine, 204.

Willow, conditions of growth, 90, 117, 156, 18t, 194.

Wind, effect on trees, 100-105; breaks, 104, 158.

Windsor, forest, 260.

Wood consumption, 21.

Woods, size of, 148, 216, 217 ; pure, 153 ; mixed, 154.

Yields of Timber Crops, 231-235; in Europe, 26 ; America, 27. 


\title{
ENGLISH ESTATE FORESTRY.
}

\author{
By A. C. FORBES, F.H.A.S.
}

With numerous Illustrations. $1 \mathrm{Vol} .12 \mathrm{~s} .6 \mathrm{~d}$, nett.

The Field.- 'It is an able contribution to estate forestry, a subject which is of vital interest to every extensive landed proprietor in this country. Since the publication of Ablett's English Trees and Iree Planting, we do not remember any book on Finglish forestry pure and simple which in all ways is quite so freshly written and so suggestive as this, and we believe that it will be regarded generally as a welcome addition to the country house library.'

Morning Post. - Mr. Forbes is a specialist, but a specialist who knows well how to make his subject interesting to the public at large. He has had a long experience in all kinds of practical forestry, and his book bears on every page traces of careful and logical study of a highly important subject. The book is one of uncommon interest, and should have a place in the library of every country house where its advice can be of value.'

The Times.- 'Mr. Forbes' book is well written, and deals very fully and suggestively with the subjects of most importance to the practical forester or woodland proprietor. We may add that there is in the book a great deal of matter which will interest country lovers in general.'

Pall Mall Gazette.-'We congratulate Mr. A. C. Forbes on the thoroughness with which he has accomplished his task. The book is full of hints for estate-owner, factor, and forester alike.'

St. James's Gazette.-'Full of interesting reading and good illustrations.'

Country Gentleman.-'There is abuudant opportunity of usefulness for such a treatment of the subject from the purely English point of view as is given in Mr. Forbes' capital and interesting volume. The book has useful and suggestive illustrations, and is written in a practical spirit, and with an abundance of detailed consideration which will make it both valuable and interesting to every landowner.'

LONDON : EDWARD ARNOLD, 41 \& 43 MADDOX STREET, W. 
The Principles of Landed Estate Management. By Henry Herbert Smimr, Fellow of the Institution of Surveyors, and Agent to the Marquess of Lansdowne, K.G., the Earl of Crewe, Major-General the Lord Methuen, etc. With Plans and Illustrations. One volume. Demy 8vo. 336 pages. 16s.

Standard. - 'In this most useful and interesting book Mr. Smith has compressed into little more than 300 pages as much practical information and sound advice as many writers would have spread over three volumes. We can confidently recommend the volume to all persons either directly or indirectly connected with the important subject of which it treats.'

Wood: A Manual of the Natural History and Industrial Applications of the Timbers of Commerce. By G. S. Boulgri, F.L.S., F.G.S., A.S I., Professor of Botany and Lecturer on Forestry in the City of London College, and Honorary Professor of Natural History in the Royal Agricultural College. With many illustrations, including a large number of new full-page plates from micro-photographs of sections of wood. One volume. Demy 8vo. 12s. 6d. nett.

Field.-'It is just the book that has long been wanted by land agents, foresters, and woodmen, and it should find a place in all technical school libraries.'

Forest Life and Sport in India. By SAINTHIL EardekYWILмот, C.I.E., lately Inspector-General of Forests to the Indian Goverument; Commissioner under the Development and Road Improvement Funds Act. With illustrations from photographs by Mabel Eardley-IViliot. Demy 8vo. 12s. 6d. nett.

United Service Magazine.-'Armed with the experiences of thirty. five years' service, during thirteen of which he held the post of Inspector General of Forests; devoted to his work, never tired of learning more about it, and aided, moreover, by literary gifts of a very high order, Mr. Eardley-IVilmot has bcen enabled to provide his readers with a book which is the more instructive because it is so charmingly written, and which will appeal with equal success to Indian Forest Officers, or to people who have never set foot in India.'

\section{The Forests of Upper India and their Inhabitants.}

By Thomas WV. Webber, late Forest Surveyor for the North-TVest Provinces, and Deputy Conservator of Forests in the Central Provinees and Gorakhpur. With Maps. Demy 8vo. 12s. 6d. nett.

Spectator.- 'This is an excellent book, full of new facts, pleasantly and easily written, and well worthy of a place in a country house library.'

LONDON: EDWARD ARNOLD, 41 \& 43 MADDOX STREET, Wr. 


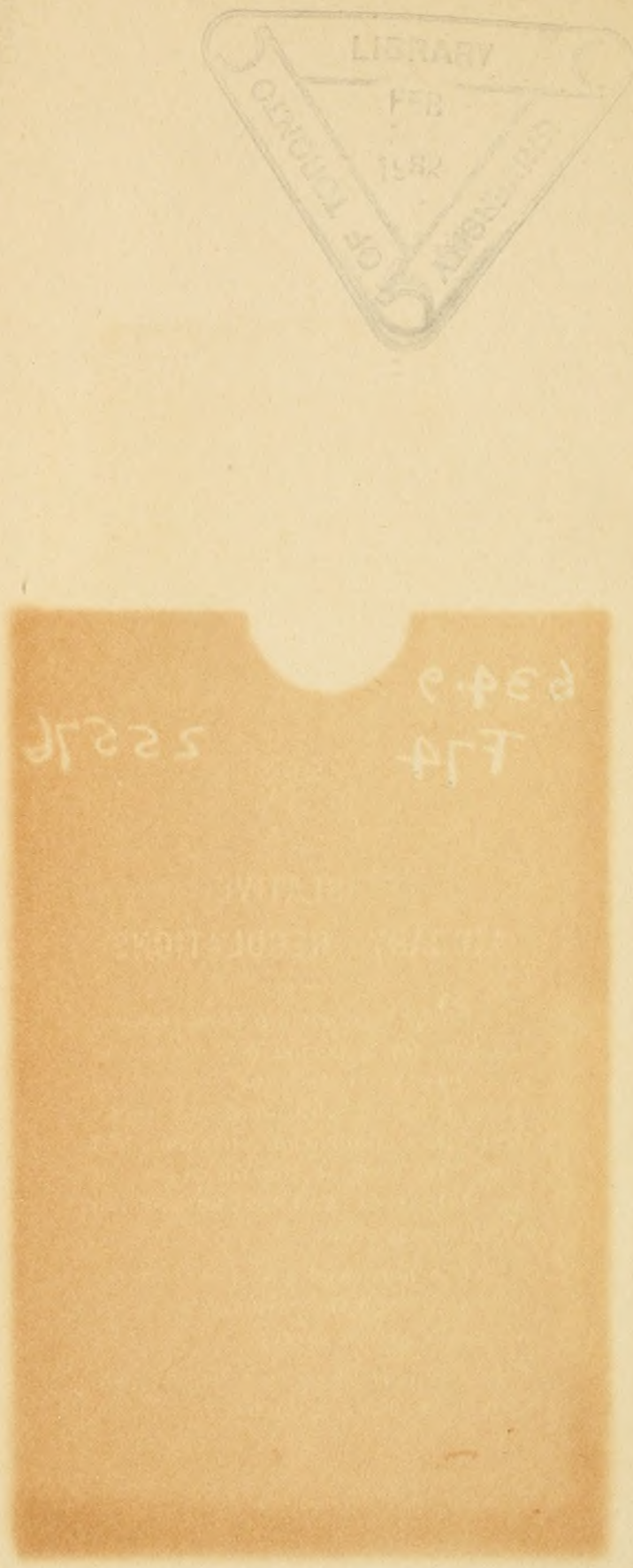


\section{PLEASE DO NOT REMOVE CARDS OR SLIPS FROM THIS POCKET}

\section{UNIVERSITY OF TORONTO LIBRARY}

SD

179

F6

cop. 2

BioMed
Forbes, A C

The development of British forestry 
